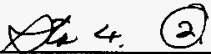

FEB 131997 ENGINEERING dATA TRANSMItTAL

Page 1 of

1. EDT 601043

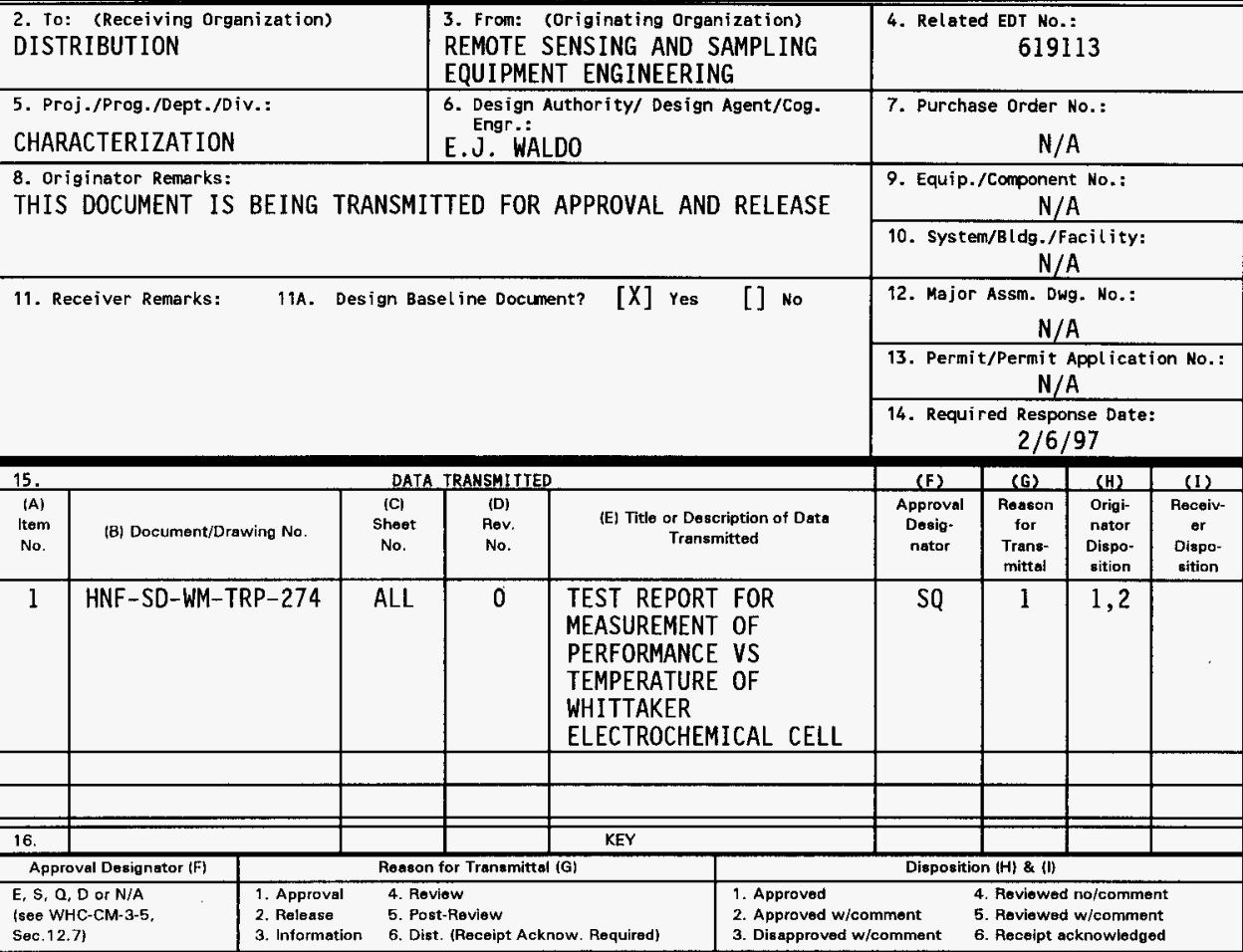

17. SIGNATURE/DISTRIBUTION

(See Approval Designator for roquired signaturesi

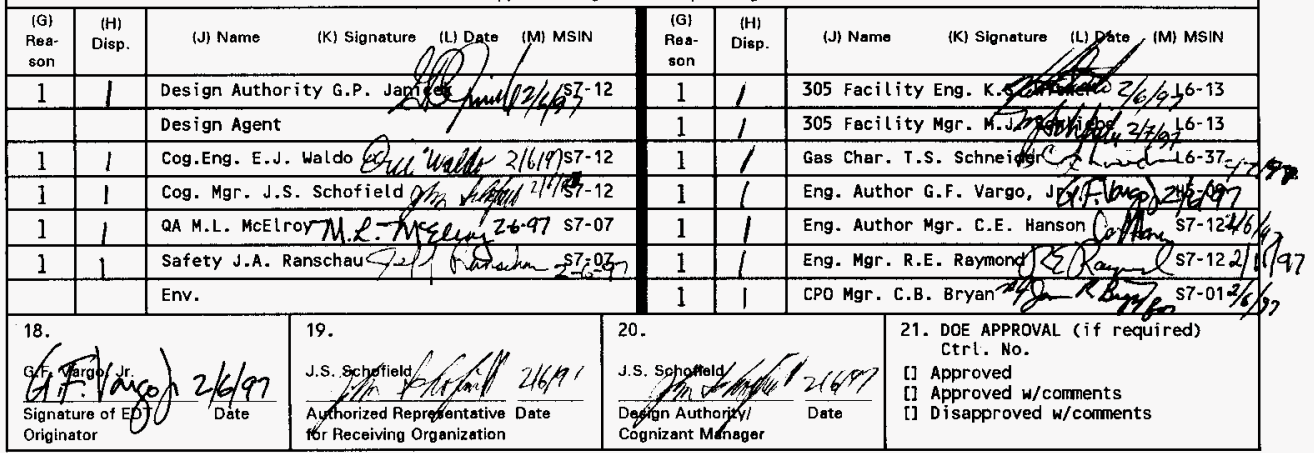




\section{INSTRUCTIONS FOR COMPLETION OF THE ENGINEERING DATA TRANSMITTAL}

(USE BLACK INK OR TYPE)

\begin{tabular}{|c|c|}
\hline BLOCK & TITLE \\
\hline$(1)^{*}$ & EDT \\
\hline (2) & To: (Receiving Organization) \\
\hline (3) & From: (Originating Organization \\
\hline (4) & Related EDT No. \\
\hline$(5)^{*}$ & Proj./Prog./Dept./Div. \\
\hline$(6)^{*}$ & Cognizant Engineer \\
\hline (7) & Purchase Order No. \\
\hline$(8)^{*}$ & Originator Remarks \\
\hline (9) & Equipment/Component No. \\
\hline$(10)$ & System/BIdg./Facility \\
\hline (11) & Receiver Remarks \\
\hline (12) & Major Assm. Dwg. No. \\
\hline (13) & Permit/Permit Application No. \\
\hline (14) & Required Response Date \\
\hline
\end{tabular}

(15)* Data Transmitted
(A)" Item Number
(B) * Document/Drawing No.
(C)* Sheet No.
(D) * Rev. No.
(E) Title or Description of Data Transmitted
(F) * Impect Level
(G) Reason for Transmittal
(H) Originator Disposition
(I) Receiver Disposition

(16) KoY

(17) Signature/Distribution
(G) Reeson
(H) Disposition
(J) Name
(K) * Signature
(L)* Date
(M) * MSIN

(18) Signature of EDT Originator

(19) Authorized Representative for Receiving Orgenization

(20)* Cognizant Manager

(21). DOE Approval
- Pre-assigned EDT number.

- Enter the individual's name, title of the organization, or entity (e.g., Distribution) that the EDT is being transmitted to.

- Enter the title of the organization originating and transmitting the EDT.

- Enter EDT numbers which relate to the data being transmitted.

- Enter the Project/Program/Department/Division title or Project/Program acronym or Project Number, Work Order Number or Organization Code.

- Enter the name of the individual identified as being responsible for coordinating disposition of the EDT.

- Enter related Purchase Order (P.O.) Number, if available.

- Enter special or additional comments concerning transmittal, or "Key" retrieval words may be entered.

- Enter equipment/component number of affected item, if appropriate.

- Enter appropriate system, building or facility number, if appropriate.

- Enter special or additional comments concerning transmittal.

- Enter applicable drawing number of major assembly, if appropriate.

- Enter applicable permit or permit application number, if appropriate.

- Enter the date a response is required from individuals identified in Block 17 (Signature/Distribution).

- Enter sequential number, beginning with 1, of the information listed on EDT.

- Enter the unique identification number assigned to the document or drawing being transmitted.

- Enter the sheet number of the information being transmitted. If no sheet number, leave blank.

- Enter the revision number of the information being transmitted. If no revision number, leave blank.

- Enter the title of the document or drawing or a brief description of the subject if no title is identified.

- Enter the appropriate Impact Level (Block 15). Also, indicate the appropriate approvals for each item listed, i.e., SQ, ESQ, etc. Use NA for non-engineering documents.

- Enter the appropriate code to identify the purpose of the data trensmittal (see Block 16).

- Enter the appropriate disposition code (see Block 16).

- Enter the appropriate disposition codo (see Btock 16).

- Number codes used in completion of Blocks $15(\mathrm{G}),(\mathrm{H})$, and (I), and $17(\mathrm{G}),(\mathrm{H})$ (Signature/Distribution).

- Enter the code of the reason for transmittal (Block 16).

- Enter the code for the disposition (Block 16).

- Enter the signature of the individual completing the Disposition $17(\mathrm{H})$ and the Transmittal.

- Obtain appropriate signature(s).

- Enter date signature is obtained.

- Enter MSIN. Note: If Distribution Sheat is used, show entire distribution (including that indicated on Page 1 of the EDT) on the Distribution Shest.

- Enter the signature and date of the individual originating the EDT (entered prior to transmittal to Receiving Organization). If the EDT originator is the cognizant engineer, sign both Blocks 17 and 18 .

- Enter the signature and date of the individual identified by the Receiving Organization as authorized to approve disposition of the EDT and acceptance of the data transmitted, as applicable.

- Enter the signature and date of the cognizant manager. (This signature is authorization for release.)

- Enter DOE approval (if required) by letter number and indicate DOE action.

*Asterisk denote the required minimum items check by Configuration Documentation prior to release; these are the minimum release requirements. 
HNF-SD-WM-TRP-274, Rev. 0

\title{
TEST REPORT FOR MEASUREMENT OF PERFORMANCE VS TEMPERATURE OF WHITTAKER ELECTROCHEMICAL CELL
}

\author{
G. F. Vargo, Jr.
}

SGN Eurisys Services Corporation, Richland, WA 99352

U.S. Department of Energy Contract DE-AC06-87RL10930

EDT/ECN: 601043

Org Code: 08E00

B\&R Code: EW3120074
UC: $: 2070$

Charge Code: N4H3B

Total Pages: 181275 ems $2 / 43 / 47$

Key Words: Whittaker, WEC, electrochemical, FGI, Hydorgen, ETL

Abstract: This document is the test report that summarizes the results of the tests on the Whittaker cells between the temperatures of $-20^{\circ} \mathrm{F}$ and $+120^{\circ} \mathrm{F}$. These sensors are used on the Rotary Mode Core Sampling (RMCS) flammable gas interlock (FGI), to detect and quantify hydrogen gas. The test consisted of operating five whittaker electrochemical cells in an environmental chamber that was varied in temperature from $-20^{\circ} \mathrm{F}$ to $+120^{\circ} \mathrm{F}$. As the rate rise of the voltage from the cells changed, after exposure to a gas concentration of $1 \%$ hydrogen at the different temperatures, the voltage was recorded on a computer controlled data acquisition system. Analysis of the data was made to determine if the cells maximum output voltages and rise times were effected by temperature.

TRADEMARK DISCLAIMER. Reference herein to any specific commercial product, process, or service by trade name, trademark, manufacturer, or otherwise, does not necessarily constitute or imply its endorsement, recommendation, or favoring by the United States Government or any agency thereof or its contractors or subcontractors.

Printed in the United States of America. To obtain copies of this document, contact: WHC/BCS Document Control Services, P.0. Box 1970, Mailstop H6-08, Richland WA 99352, Phone (509) 372-2420; Fax (509) 376-4989.

Hewlett-Packard is a trademark of Hewlett-Packard Whittaker is a trademark of Whittaker Corp.
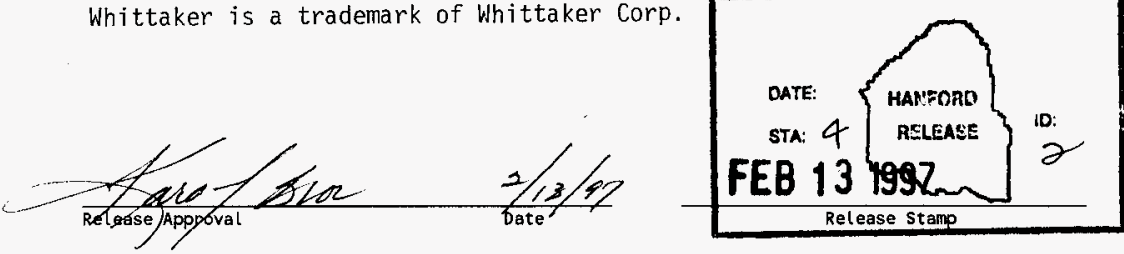

\section{Approved for Public Release}


THIS PAGE INTENTIONALLY LEFT BLANK 
HNF-SD-WM-TRP-274

Rev 0

\section{TEST REPORT FOR THE MEASUREMENT OF PERFORMANCE V.S. TEMPERATURE OF THE WHITTAKER ELECTROCHEMICAL CELL}

G. F. Vargo, Jr.

SGN Eurisys Services Corporation, Richland, WA 99352

U.S. Department of Energy Contract DE-AC06-87RL10930 
THIS PAGE INTENTIONALLY LEFT BLANK 
HNF-SD-WM-TRP-274

Rev 0

TABLE OF CONTENTS

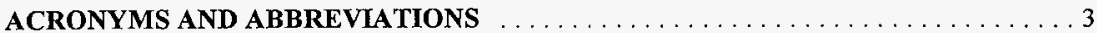

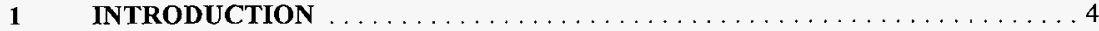

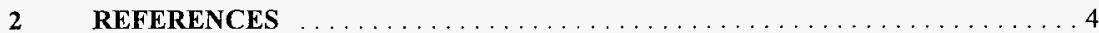

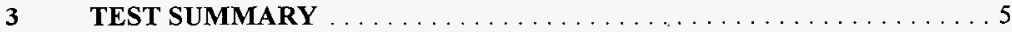

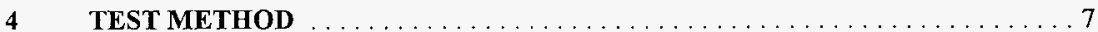

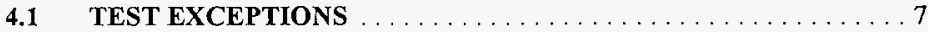

4.1.1 EXCEPTION $\# 1$. . . . . . . . . . . . . 7

4.1.2 EXCEPTION $\# \mathbf{2} \ldots \ldots \ldots \ldots \ldots \ldots$

4.1.3 EXCEPTION \#3 $\ldots \ldots \ldots \ldots \ldots \ldots \ldots \ldots$

4.1.4 EXCEPTION $\# \mathbf{4} \ldots \ldots \ldots \ldots \ldots \ldots \ldots$

4.1.5 EXCEPTION $\# \mathbf{5} \ldots \ldots \ldots \ldots \ldots \ldots$

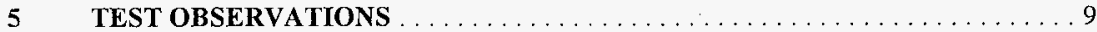

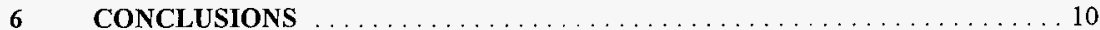

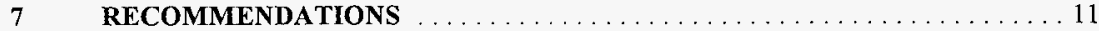

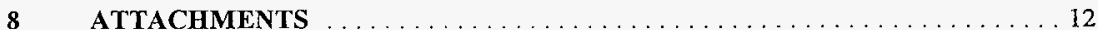

8.1 ATTACHMENT 1: TABLE 1 - TEST RESULTS SUMMARY $\ldots \ldots \ldots 13$

8.2 ATTACHMENT 2: WHITTAKER CELL \#2 \& 4 WITH 100\%

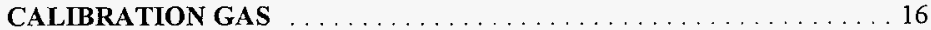

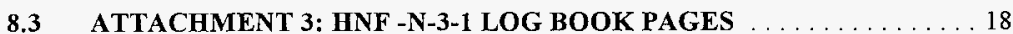

8.4 ATTACHMENT 4: HNF-SD-WM-TC-072, Rev $0 \ldots \ldots \ldots \ldots \ldots$

8.5 ATTACHMENT 5: SUPPORTING DOCUMENTATION . . . . . . . 146 
THIS PAGE INTENTIONALLY LEFT BLANK 
HNF-SD-WM-TRP-274

Rev 0

\section{ACRONYMS AND ABBREVIATIONS}

CPO

ETL

FGI

HP

PPM

WEC

Characterization Project Operations

Engineering Test Laboratory

Flammable Gas Interlock

Hewlett Packard

Parts per Million

Whittaker Electrochemical Cell

Page 3 
THIS PAGE INTENTIONALLY

LEFT BLANK 
HNF-SD-WM-TRP-274

Rev 0

\section{TEST REPORT \\ FOR THE MEASUREMENT OF \\ PERFORMANCE V.S. TEMPERATURE \\ OF WHITTAKER \\ ELECTROCHEMICAL CELL}

\section{INTRODUCTION}

The purpose of this test report is to summarize the "to date" performance testing, at various temperatures, of the WEC and to select a WEC, for use on the FGI, based on the data to date and this test report. The WEC cell is used on the FGI, for rotary mode core sampling (RMCS), to detect and quantify the presence of hydrogen gas concentration. The test consisted of operating five (5) WECs in an environmental chamber that was varied in temperature from $-20^{\circ} \mathrm{F}$ to $120^{\circ} \mathrm{F}$. As the rate rise of the voltage from the WECs changed, after exposure to a calibration gas concentration of $1 \%$ hydrogen at the different temperatures, the voltages were recorded on a computer controlled data acquisition system. Analysis of the data was made to determine if the cells maximum voltages and rise times met the criteria as specified in HNF-SDWM-TP-527.

The manufacturers' recommended operating range is $+70^{\circ} \mathrm{F}$ to $+120^{\circ} \mathrm{F}$. However, the temperature range for this test was increased from $-20^{\circ} \mathrm{F}$ to $+120^{\circ} \mathrm{F}$ to investigate if the WECs could be operated beyond their specified range.

This testing was performed in the 305 ETL at the Hanford Site, Richland, Washington.

As additional data is gathered this document will be revised to report the new data.

\section{REFERENCES}

2.1 HNF-SD-WM-TP-527, Test Plan for Measurement of Performance V.S. Temperature of Whittaker Electrochemical Cell, Rev, 0, SGN Eurisys Services Corporation, Richland, Washington, 99352, January 1997.

2.2 HNF-SD-WM-TC-072. Test Procedure for Measurement of Performance y.s. Temperature of Whittaker Cell, Rev, 0, SGN Eurisys Services Corporation, Richland, Washington, 99352, January 1997. 
THIS PAGE INTENTIONALLY LEFT BLANK 


\section{HNF-SD-WM-TRP-274}

\section{$\operatorname{Rev} 0$}

2.3 HNF-N-3-1, Testing and System Development Notes for 305 Engineering Testing Laboratory, Hanford Nuclear Facility. Issued to K. S. Witwer, 1/8/97.

\subsection{WHC-SD-WM-SAD-035. A Safety Assessment of Rotary Mode Core Sampling in Flammable Gas Single Shell Tanks, Rev 0A, Los Alamos National Laboratory, Los Alamos, New Mexico, August 1996.}

\section{TEST SUMMARY}

The format of the test plan allowed for flexibility in the performance of the test. Therefore, under recommendations from the Whittaker factory, initial testing was performed at $+40^{\circ} \mathrm{F}$, on all five $(5)$ test WECs. Based on the factory conversations, a starting point was established that if any WEC failed any of the tests, the temperature was to be increased and the cells retested using the $100 \%$ calibration rate test as an initial "pass/fail" criteria (Reference HNFSD-WM-TP-527 and HNF-SD-TC-072). All the WECs would have to pass all the tests for the temperature to be lowered. For the purpose of this report the definition of "pass/fail by" in microvolts (ppm), is the amount the $90 \%$ of the final WEC under test voltage value is "greater than"(pass), or "less than" (fail), the 2 minute WEC under test voltage value. The definition of the "final WEC under test voltage value" is the voltage value the WEC has attained after 15 minutes from injection of the calibration gas concentration (opening of solenoid valve from gas header to the WEC under test).

The results of the testing at $+40^{\circ} \mathrm{F}$ is as follows:

- all WECs, except for WEC 1, failed at least one(1) of the tests;

- $\quad$ in addition to WEC 5 failing the criteria, it was noted to be excessively noisy, i.e., $+1 /-10$ micro volt signal variation as compared to $+/-2$ microvolts for WECs $1-4$. One(1) micro volt equates to nominally $10 \mathrm{ppm}$. A typical WEC output voltage response would be from 0.0 microvolts $(0.0 \mathrm{ppm})$ at $0 \%$ hydrogen to 1000 microvolts $(10,000 \mathrm{ppm})$ at $1 \%$ hydrogen.

Since at least one(1) failure was noted, the temperature was increased to $+50^{\circ} \mathrm{F}$. WECs 2 and 4 were tested at the $100 \%$ calibration rate test. WECs 2 and 4 were a randomly selected sample for this test.

The results of the testing at $+50^{\circ} \mathrm{F}$ is as follows:

- $\quad$ WEC 2 (HP data file WEC 252) failed by 7.9 microvolts (79 ppm);

- WEC 4 (HP data file WEC 452) passed by 27.5 microvolts (275 ppm). 
THIS PAGE INTENTIONALLY LEFT BLANK 


\section{HNF-SD-WM-TRP-274}

\section{Rev 0}

Since WEC 2 failed, the temperature was increased to $+60^{\circ} \mathrm{F}$ and all WECs were tested at the $100 \%$ calibration rate test with the following results:

- $\quad$ WEC 1 (HP data file WEC 162) passed by 17.6 microvolts (176 ppm);

- $\quad$ WEC 2 (HP data file WEC 262) passed by 42.7 microvolts (427 ppm);

- $\quad$ WEC 3 (HP data file WEC 362) failed by 9 microvolts (90 ppm);

- $\quad$ WEC 4 (HP data file WEC 462) passed 57 microvolts (570 ppm);

- WEC 5 (HP data file WEC 562) failed by 79.6 microvolts (796 ppm).

At this time the 305 ETL team called for a consultation meeting with T.C. Schneider, in regards to the performance of WEC 5. After a reverification that the data acquisition system was functioning correctly, and after an examination of WEC 5 and it's configuration in the test setup, Schneider could not determine if anything was wrong with WEC 5. He stated that the polyamide membrane, used in the WECs as a diffusion barrier, could be slightly thicker on that particular WEC. This could be the cause for the slow response time. However, the excessive noise could not be readily explained. Additional testing of WEC 5 is recommended. WEC 5 has failed all tests to date.

Since WEC 3 had failed at $+60^{\circ} \mathrm{F}$, the temperature was increased to $+65^{\circ} \mathrm{F}$ and WEC 3 was tested with the following results:

- WEC 3 (HP data file 363) failed by 1 microvolt (10 ppm);

- $\quad$ WEC 3 (HP data file 364 ) passed by 7.3 microvolts (73 ppm).

Two(2) tests were performed because the first test failed by the small margin of 1 microvolt. The second test passed. However, the initial starting value was higher ( 9 microvolts versus 3 microvolts).

NOTE 1: When testing first commenced the testing team discovered that the configuration of the test setup caused calibration gas from an online WEC to contaminate an offline WEC through the common exhaust header. This cause a high initial offset voltage (100 - 500 microvolts). However, this was corrected. Future testing, after the correction to the vents was implemented, showed the initial starting voltages repeatedly approached a consistent value after consecutive testing.

The temperature was increased to $+70^{\circ} \mathrm{F}$. All WECs were tested with the following results: 
THIS PAGE INTENTIONALLY LEFT BLANK 


\section{HNF-SD-WM-TRP-274}

\section{Rev 0}

- $\quad$ WEC 1 (HP data file 172) passed by 17.6 microvolts (176 ppm);

- WEC 2 (HP data file 272) passed by 51 microvolts ( $510 \mathrm{ppm}$ );

- WEC 3 (HP data file 372) passed by 18.9 microvolts (189);

- $\quad$ WEC 4 (HP data file 472) passed by 70.4 microvolts (704 ppm);

- WEC 5 (HP data file 572 ) failed by 49.6 microvolts (496 ppm).

The temperature was increased to $+80^{\circ} \mathrm{F}$. The results are listed below:

- $\quad$ WEC 1 (HP data file 182) failed by 7 microvolts (70 ppm);

- WEC 1 (HP data file 183) passed by 6.6 microvolts (66 ppm);

- WEC 1 (HP data file 184) failed by 10.3 microvolts (103 ppm);

- WEC 2 (HP data file 282) passed 58.3 microvolts (583 ppm);

- WEC 4 (HP data file 482) passed 74 microvolts (740 ppm).

The temperature was increased to $+100^{\circ} \mathrm{F}$. The results are listed below:

- $\quad$ WEC 2 (HP data file 212 ) passed by 48.5 microvolts ( $485 \mathrm{ppm}$ );

- WEC 4 (HP data file 412) passed 97.3 microvolts (973 ppm).

The temperature was increased to $+120^{\circ} \mathrm{F}$. The results are listed below:

- WEC 2 (HP data file 222) passed 64.3 microvolts (643 ppm);

- WEC 4 (HP data file 422) passed 64.7 microvolts (647 ppm).

WECs 2 or 4 can be used on the FGI as per the criteria stated in WHC-SD-WM-SAD-035. The WECs should be calibrated at a temperature of $100^{\circ} \mathrm{F}$ and operated between $80^{\circ} \mathrm{F}$ and $100^{\circ} \mathrm{F}$. Alternately the WECs could be calibrated at $70^{\circ} \mathrm{F}$ or $80^{\circ} \mathrm{F}$ and operated from the calibration temperature down to $10^{\circ} \mathrm{F}$ below the calibration temperature. The WECs may be operated at temperatures less than the values stated above, however the SAD-035 limit of $\leq$ 1,000 ppm prior to sampling will likely not be achievable. The WECs must be kept above $60^{\circ}$ to maintain the $90 \%$ response in two minutes requirement of SAD-035. (REF: APPENDIX, “ANALYSTS OF TEMPERATURE EFFECTS ON WHITTAKER CELL CALIBRATION”.)

\section{TEST METHOD}

\subsection{TEST EXCEPTIONS}

\subsubsection{EXCEPTION \#1}

Before the testing began the testing team decided, after discussions with T. C. Schneider 
THIS PAGE INTENTIONALLY LEFT BLANK 


\section{HNF-SD-WM-TRP-274}

\section{$\operatorname{Rev} 0$}

from the gas characterization team, to modify the wiring configuration of the test setup to include an isolation relay between the Stahl intrinsic isolating voltage repeater(s) and the WEC(s). This would allow voltage measurements to be made on the WEC(s) isolated from any interfacing device.

This configuration was implemented by the addition of a $+24 \mathrm{Vdc}$ relay that was obtained from 305 ETL electronics laboratory. The contacts of the relay were inspected and found to be of gold for low contact resistance. Furthermore, the relay was tested, using the Fluke documenting calibrator ( Fluke Manufacturing Inc. Test instrument), by injecting and reading a microvolt signal across the energized closed relay contacts. A control switch was installed on the test control panel that deenergized (disconnected the WEC(s) from the barrier(s)) or energize (connect the WEC(s) to the barrier(s)). Reference page 12 of ETL note book HNF-N-3-1 and Appendix C of HNF-SD-WM-TC-072.

This exception was resolved by implementation and approved by the test director, 305 ETL testing engineer, and the RMCS exhauster engineer as authorized by HNF-SD-WM-TP-527, Sections 3.1.1.2.

\subsubsection{EXCEPTION \#2}

Before testing began CPO had sent an engineer to the Whittaker factory, in Simi Valley, California, to talk to the Whittaker engineering team first hand. These discussions led to a recommendation from Whittaker that the temperature testing be started at $+40^{\circ}$. And if all the WECs passed the criteria then the temperature could be decreased. However, if any of the WECs failed the criteria then the temperature would be increased and the WECs retested.

This exception was resolved by changing the initial temperature to $+40^{\circ}$ in step 7.4 of the test procedure HNF-SD-WM-TC-072, and approved by the test director, 305 ETL testing engineer, and the RMCS exhauster engineer as authorized by $H N F-S D-W M-T P-527$, Sections 3.I.I.2.

\subsubsection{EXCEPTION \#3}

Before the testing began the testing team decided, after discussions with T. C. Schneider from the gas characterization team, that it would be a better test if the transit time of the gas from the gas divider to the input of the WECs was minimized. This change allows the gas header supply line, up to the solenoids to the WECs, to be charged with the specific concentration of calibration gas $(30 \%, 60 \%, 90 \%)$ before allowing the gas to enter the WECs. Reference page 13 of ETL note book HNF-N-3-1 and Appendix C of HNF-SD-WM-TC-072. 
THIS PAGE INTENTIONALLY LEFT BLANK 


\section{HNF-SD-WM-TRP-274}

\section{Rev 0}

This exception was resolved by changing the order in steps 7.19-7.22 of the test procedure HNF-SD-WM-TC-072, and approved by the test director, 305 ETL testing engineer, and the RMCS exhauster engineer as authorized by $H N F-S D-W M-T P-527$, Sections 3.1.1.2.

\subsubsection{EXCEPTION \#4}

After discussing methods to reduce the test time with T.C. Schneider and after measuring the transit time of the gas from the gas divider to the WEC (approximately 25 seconds), the test team decided to change the purge time of the gas header from 15 minutes to 2 minutes. This reduces the overall test time by 13 minutes. Reference page 13 of ETL note book HNF-N-3-1 and Appendix C of HNF-SD-WM-TC-072.

This exception was resolved by changing the purge time from 15 to 2 minutes, in step 7.32 of the test procedure HNF-SD-WM-TC-072, and approved by the test director, 305 ETL testing engineer, and the RMCS exhauster engineer as authorized by $H N F-S D-W M-T P-527$, Sections 3.1.1.2

\subsubsection{EXCEPTION \#5}

During the initial testing of WECs $1-5$ at $+40^{\circ} \mathrm{F}$, a problem was observed of the WECs not returning to the initial voltage values after a test (See Note 1). After analysis of the test piping configuration it was decided to change the vents from all the WECs to individual lines instead of all WECs being connected to a common header. The analysis and observation indicated that calibration gas from on online WEC was contaminating an offline WEC. The calibration gas of the WEC under test was remaining trapped in offline WECs. Reference page 16 of ETL note book HNF-N-3-1 and Appendix C of HNF-SD-WM-TC-072.

This exception was resolved by adding individual vent lines from each WEC and removing the common vent header, and approved by the test director, 305 ETL testing engineer, and the RMCS exhauster engineer as authorized by $H N F-S D-W M-T P-527$, Sections 3.1.1.2

\section{TEST OBSERVATIONS}

1. The system data acquisition signal path loops, for every channel, were verified for accuracy before starting of the procedure. On every channel, each WEC was disconnected and a precision voltage was injected, as generated by a Fluke documenting calibrator, and was read by the Fluke and the HP data acquisition system. All channels were verified and recorded. Reference page 11 of ETL note book HNF-N-3-1.

\section{Page 9}


THIS PAGE INTENTIONALLY LEFT BLANK 


\section{HNF-SD-WM-TRP-274 \\ $\operatorname{Rev} 0$}

2. The time for the WEC to reach it's final voltage value, for the purpose of this testing, was defined at 15 minutes, a conservative time.. The criteria is based on the WEC voltage reaching $90 \%$ of the final voltage in 2 minutes. The longer the wait to reach the final voltage the faster the rate-of-rise must be within the 2 minutes. The Whittaker factory uses 10 minutes as a time to final value. If the TABLE 1 - TEST RESULTS SUMMARY is analyzed for a pass/fail criteria, using 10 minutes as a time to final value, the majority of the tests that failed for WECs 1-4 would have passed.

\section{CONCLUSIONS}

1. The resuits of the testing, that has been completed to date, has shown that WECs 2 or 4 can be used on the FGI for RMCS of single shell tanks as per WHC-SD-WM$\mathrm{SAD}-035$. The range of operation must be held between $+60^{\circ} \mathrm{F}$ and $+120^{\circ} \mathrm{F}$.

2. The test results indicate that WECs 2 and 4 can be operated below the manufacturers' recommended temperature range of $+70^{\circ} \mathrm{F}$ to $+120^{\circ} \mathrm{F}$.

3. All WECs used on the FGI must be qualification tested to verify operation in the expected temperature range. Furthermore, the WEC must be maintained in the tested temperature range during field operation.

4. An analysis of the data has shown that generally, for a given WEC test output voltage, as the temperature increases the difference between the final value at 15 minutes and the starting initial value, decreases (Reference Attachment 2). This concludes that the calibration for the FGI WECs should be performed at a higher temperature to be on the conservative side.

For the FGI application, the WECs should be calibrated at $+80^{\circ} \mathrm{F}$ and operated between $+60^{\circ} \mathrm{F}$ and $+120^{\circ} \mathrm{F}$ (Reference ATTACHMENT 5: SUPPORTING DOCUMENTATION, "ANALYSIS OF FGI WHITTAKER CELL CALIBRATION AND OPERATING TEMPERATURES").

5. The testing has shown that all WECs do not respond the same. For example, out of the five WECs selected at random, WEC \#5, has not passed any of the test "to date". Furthermore, WEC \#1 passed all the tests and WEC \#3 failed all the tests at $+40^{\circ} \mathrm{F}$.

6. Some of the WECs tested do not meet the manufacturers' specifications, i.e., WEC 5 not passing in the temperature range of $+70^{\circ} \mathrm{F}$ to $+120^{\circ} \mathrm{F}$. 
THIS PAGE INTENTIONALLY LEFT BLANK 


\section{HNF-SD-WM-TRP-274 \\ Rev 0}

\section{RECOMMENDATIONS}

1. It will be necessary to "hand select", through qualification testing, WECs for a given application.

2. Additional selective retesting could be performed, to verify the current $+40^{\circ} \mathrm{F}$ data is valid, after exception \#5 was implemented.

3. Additional testing should be performed to characterize the behavior of the initial offset voltage, i.e. changes with temperature, effects from intrinsic voltage repeating barrier, etc. A simple test would be to isolate the intrinsic barriers from the WECs and observe and record the WEC output voltage as the temperature is varied from $+40^{\circ} \mathrm{F}$ to $+120^{\circ} \mathrm{F}$.

4. Additional selective testing could be performed to characterize the temperature behavior and response time when disconnected, via the isolating relay, from the intrinsic voltage isolating repeater. The information gathered from 3 and 4 will be useful for future flammable gas monitoring activities, i.e., yields more knowledge on the behavior of the WEC, used in the Hanford Site base technology, in flammable gas monitoring.

5. Additional selective testing could be performed to characterize the temperature behavior of the WECs for all temperature not previously tested, that may be experienced in the field.

6. Additional testing/analysis is recommended for WEC 5 to investigate the excessive noise, noted on the cell output voltage, as compared to the other cells, i.e., consult factory. 
THIS PAGE INTENTIONALLY LEFT BLANK 


\section{HNF-SD-WM-TRP-274}

Rev 0

8 ATTACHMENTS

8.1 ATTACHMENT 1: TABLE 1 - TEST RESULTS SUMMARY

8.2 ATTACHMENT 2: WHITTAKER CELLS \#2 \& \#4 WITH 100\% CALIBRATION GAS

8.3 ATTACHMENT 3: HNF-N-3-1 LOG BOOK PAGES

8.4 ATTACHMENT 4: HNF-SD-WM-TC-072, Rev 0

8.5 ATTACHMENT 5: SUPPORTING DOCUMENTATION 
THIS PACE INTENTIONALLY LEFT BLANK 
HNF-SD-WM-TRP-274, REV 0

\subsection{ATTACHMENT 1: TABLE 1 - TEST RESULTS SUMMARY}

\begin{tabular}{|c|c|c|c|c|c|c|}
\hline \multicolumn{7}{|c|}{ Cell 1} \\
\hline Temperature $\left({ }^{\circ} \mathrm{F}\right)$ & $30 \%$ & $60 \%$ & $90 \%$ & $\begin{array}{c}100 \% \\
\text { (1st) }\end{array}$ & $\begin{array}{l}100 \% \\
\text { (2nd) }\end{array}$ & $\begin{array}{l}100 \% \\
\text { (3rd) }\end{array}$ \\
\hline 40 & $\begin{array}{c}P \\
1 / 25 / 97\end{array}$ & $\begin{array}{c}\mathrm{P} \\
1 / 25 / 97\end{array}$ & $\underset{1 / 25 / 97}{P}$ & $\begin{array}{c}\mathrm{P} \\
1 / 25 / 97\end{array}$ & $\begin{array}{c}\mathrm{P} \\
1 / 25 / 97\end{array}$ & $\stackrel{P}{P}=$ \\
\hline \multicolumn{7}{|l|}{50} \\
\hline 60 & & & & $\begin{array}{c}\mathrm{P} \\
1 / 29 / 97\end{array}$ & & \\
\hline \multicolumn{7}{|l|}{65} \\
\hline 70 & & & & $\begin{array}{c}P \\
1 / 29 / 97\end{array}$ & & \\
\hline 80 & & & & $\begin{array}{c}F \quad * \\
1 / 30 / 97\end{array}$ & $\underset{1 / 30 / 97}{P}$ & $\begin{array}{c}F^{*} \\
1 / 30 / 97\end{array}$ \\
\hline \multicolumn{7}{|l|}{100} \\
\hline 120 & & & & & & \\
\hline
\end{tabular}

The asterisk " "**"next to some of the failures $(F)$ in this table indicates tests that would have passed if the final value time had been 10 minutes (instead of 15 minutes) - which happens to be the time Whittaker uses for their qualification testing at their factory. 
THIS PAGE INTENTIONALLY LEFT BLANK 
HNF-SD-WM-TRP-274, REV 0

TABLE 1 - TEST RESULTS SUMMARY - CONT

\begin{tabular}{|c|c|c|c|c|c|c|}
\hline \multicolumn{7}{|c|}{ Cell 2} \\
\hline Temperature $\left({ }^{\circ} \mathrm{F}\right)$ & $30 \%$ & $60 \%$ & $90 \%$ & $\begin{array}{c}100 \% \\
(1 \mathrm{st})\end{array}$ & $\begin{array}{l}100 \% \\
\text { (2nd) }\end{array}$ & $\begin{array}{l}100 \% \\
\text { (3rd) }\end{array}$ \\
\hline 40 & $\begin{array}{c}P \\
1 / 27 / 97\end{array}$ & $\begin{array}{c}\mathrm{P} \\
1 / 27 / 97\end{array}$ & $\begin{array}{c}\mathrm{P} \\
1 / 27 / 97\end{array}$ & $\underset{1 / 27 / 97}{P}$ & $\begin{array}{c}F \\
\text { H/27/97 }\end{array}$ & $\begin{array}{c}F * \\
1 / 27 / 97\end{array}$ \\
\hline 50 & & & & $\begin{array}{c}F * \\
1 / 28 / 97\end{array}$ & & \\
\hline 60 & $\begin{array}{c}\mathrm{P} \\
(2 / 3 / 97)\end{array}$ & $\begin{array}{c}\mathrm{P} \\
(2 / 3 / 97)\end{array}$ & $\begin{array}{c}\mathbf{P} \\
(2 / 3 / 97)\end{array}$ & $\underset{1 / 29 / 97}{\mathrm{P}}$ & & \\
\hline \multicolumn{7}{|l|}{65} \\
\hline 70 & $\begin{array}{c}\mathrm{P} \\
2 / 4 / 97\end{array}$ & $\begin{array}{c}\mathrm{P} \\
2 / 4 / 97\end{array}$ & $\underset{2 / 4 / 97}{P}$ & $\underset{1 / 29 / 97}{\mathrm{P}}$ & & \\
\hline 80 & & & & $\begin{array}{c}\mathrm{P} \\
1 / 31 / 97\end{array}$ & & \\
\hline 100 & & & & $\underset{1 / 31 / 97}{P}$ & & \\
\hline 120 & & & & $\begin{array}{c}\mathrm{P} \\
2 / 1 / 97\end{array}$ & & \\
\hline
\end{tabular}

\begin{tabular}{|c|c|c|c|c|c|c|}
\hline \multicolumn{7}{|c|}{ Cell 3} \\
\hline Temperature $\left({ }^{\circ} \mathrm{F}\right)$ & $30 \%$ & $60 \%$ & $90 \%$ & $\begin{array}{r}100 \% \\
(1 \mathrm{st})\end{array}$ & $\begin{array}{l}100 \% \\
\text { (2nd) }\end{array}$ & $\begin{array}{l}100 \% \\
\text { (3rd) }\end{array}$ \\
\hline 40 & $\begin{array}{c}F \\
1 / 27 / 97\end{array}$ & $\begin{array}{c}F \\
1 / 27 / 97\end{array}$ & $\underset{1 / 27 / 97}{F}$ & $\underset{1 / 27 / 97}{\mathbf{F}}$ & $\underset{1 / 27 / 97}{F}$ & $\begin{array}{c}F \\
1 / 27 / 97\end{array}$ \\
\hline \multicolumn{7}{|l|}{50} \\
\hline 60 & & & & $\begin{array}{c}F \quad{ }^{*} \\
1 / 29 / 97\end{array}$ & & \\
\hline 65 & & & & $\begin{array}{c}\mathrm{F}{ }^{*} \\
1 / 29 / 97\end{array}$ & $\underset{1 / 29 / 97}{\mathrm{P}}$ & \\
\hline 70 & & & & $\underset{1 / 29 / 97}{P}$ & & \\
\hline \multicolumn{7}{|l|}{80} \\
\hline \multicolumn{7}{|l|}{100} \\
\hline 120 & & & & & & \\
\hline
\end{tabular}


THIS PAGE INTENTIONALLY LEFT BLANK 
HNF-SD-WM-TRP-274, REV 0

TABLE 1 - TEST RESULTS SUMMARY - CONT.

\begin{tabular}{|c|c|c|c|c|c|c|}
\hline \multicolumn{7}{|c|}{ Cell 4} \\
\hline Temperature $\left({ }^{\circ} \mathrm{F}\right)$ & $30 \%$ & $60 \%$ & $90 \%$ & $\begin{array}{c}100 \% \\
\text { (1st) }\end{array}$ & $\begin{array}{l}100 \% \\
\text { (2nd) }\end{array}$ & $\begin{array}{l}100 \% \\
\text { (3rd) }\end{array}$ \\
\hline 40 & $\begin{array}{c}\mathrm{P} \\
1 / 28 / 97\end{array}$ & $\begin{array}{c}F \\
1 / 28 / 97\end{array}$ & $\begin{array}{c}\mathbf{F} \\
1 / 28 / 97\end{array}$ & $\begin{array}{c}\mathrm{F} \\
1 / 28 / 97\end{array}$ & $\underset{1 / 28 / 97}{F}$ & $\begin{array}{c}F \\
1 / 28 / 97\end{array}$ \\
\hline 50 & $\begin{array}{c}P \\
2 / 4 / 97\end{array}$ & $\begin{array}{c}P \\
2 / 4 / 97\end{array}$ & $\begin{array}{c}P \\
2 / 4 / 97\end{array}$ & $\begin{array}{c}\mathrm{P} \\
1 / 28 / 97\end{array}$ & & \\
\hline 60 & $\begin{array}{c}P \\
2 / 3 / 97\end{array}$ & $\begin{array}{c}\mathrm{P} \\
2 / 3 / 97\end{array}$ & $\begin{array}{c}P \\
2 / 3 / 97\end{array}$ & $\begin{array}{c}\mathrm{P} \\
{[/ 29 / 97}\end{array}$ & & \\
\hline \multicolumn{7}{|l|}{65} \\
\hline 70 & $\begin{array}{c}P \\
2 / 3 / 97\end{array}$ & $\begin{array}{c}\mathrm{P} \\
2 / 3 / 97\end{array}$ & $\underset{2 / 4 / 97}{P}$ & $\begin{array}{c}\mathrm{P} \\
1 / 29 / 97\end{array}$ & & \\
\hline 80 & $\begin{array}{c}\mathrm{P} \\
2 / 4 / 97\end{array}$ & $\begin{array}{c}\mathrm{P} \\
2 / 4 / 97\end{array}$ & $\begin{array}{c}P \\
2 / 4 / 97\end{array}$ & $\begin{array}{c}\mathrm{P} \\
1 / 31 / 97\end{array}$ & & \\
\hline 100 & & & & $\begin{array}{c}P \\
1 / 31 / 97\end{array}$ & & \\
\hline 120 & & & & $\begin{array}{c}\mathrm{P} \\
1 / 31 / 97\end{array}$ & & \\
\hline
\end{tabular}

\begin{tabular}{|c|c|c|c|c|c|c|}
\hline \multicolumn{7}{|c|}{ Cell 5} \\
\hline Temperature $\left({ }^{\circ} \mathrm{F}\right)$ & $30 \%$ & $60 \%$ & $90 \%$ & $\begin{array}{c}100 \% \\
\text { (1st) }\end{array}$ & $\begin{array}{l}100 \% \\
\text { (2nd) }\end{array}$ & $\begin{array}{l}100 \% \\
\text { (3rd) }\end{array}$ \\
\hline 40 & $\begin{array}{c}F \\
1 / 28 / 97\end{array}$ & $\begin{array}{c}F \\
1 / 28 / 97\end{array}$ & $\begin{array}{c}F \\
1 / 28 / 97\end{array}$ & $\begin{array}{c}F \\
1 / 28 / 97\end{array}$ & $\begin{array}{c}F \\
1 / 28 / 97\end{array}$ & $\begin{array}{c}F \\
I / 28 / 97\end{array}$ \\
\hline 50 & & & & $\begin{array}{c}F \\
1 / 29 / 97\end{array}$ & & \\
\hline 60 & & & & $\begin{array}{c}F \\
1 / 29 / 97\end{array}$ & & \\
\hline \multicolumn{7}{|l|}{65} \\
\hline 70 & & & & $\begin{array}{c}F \\
1 / 29 / 97\end{array}$ & & \\
\hline \multicolumn{7}{|l|}{80} \\
\hline \multicolumn{7}{|l|}{100} \\
\hline 120 & & & & & & \\
\hline
\end{tabular}


THIS PAGE INTENTIONALLY LEFT BLANK 
HNF-SD-WM-TRP-274

$\operatorname{Rev} 0$

\subsection{ATTACHMENT 2: WHITTAKER CELL \#2 WITH 100\% CALIBRATION GAS}

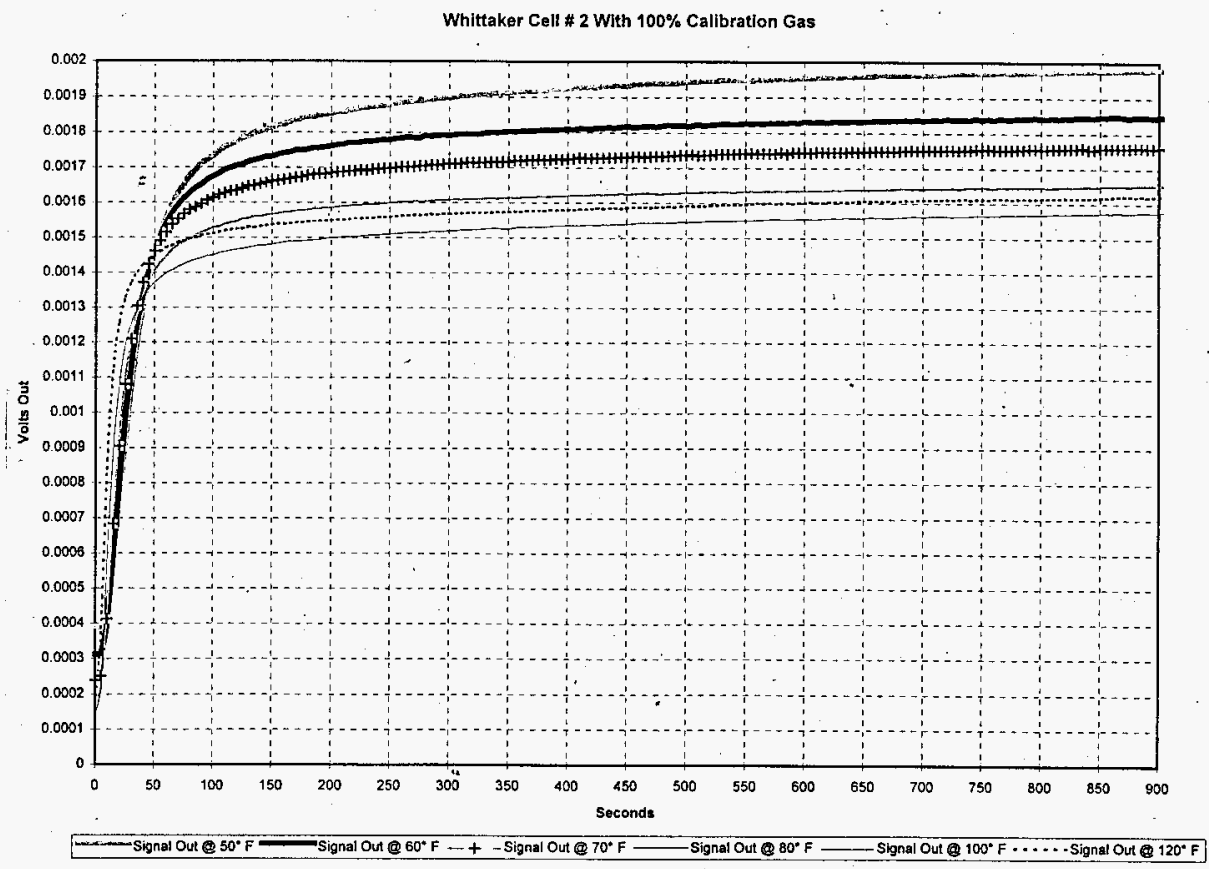

Page 16 
THIS PAGE INTENTIONALLY LEFT BLANK 


\section{HNF-SD-WM-TRP-274}

$\operatorname{Rev} 0$

\subsubsection{ATTACHMENT 2: WHITTAKER CELL \#4 WITH 100\% CALIBRATION GAS}

Whittaker Cell \# 4 With $100 \%$ Calibration Gas

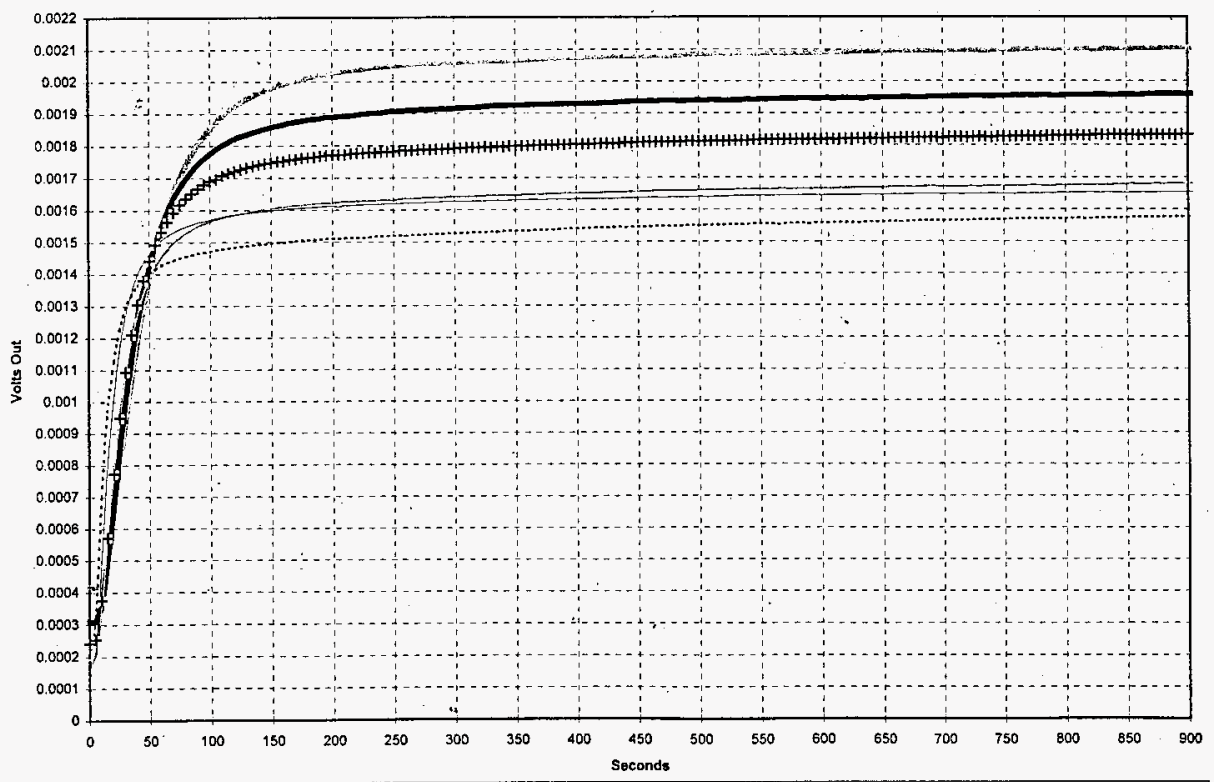


THIS PAGE INTENTIONALLY LEFT BLANK 


\section{HNF-SD-WM-TRP-274}

Rev 0

8.3 ATTACHMENT 3: HNF -N-3-1 LOG BOOK PAGES

Page 18 
THIS PAGE INTENTIONALLY LEFT BLANK 


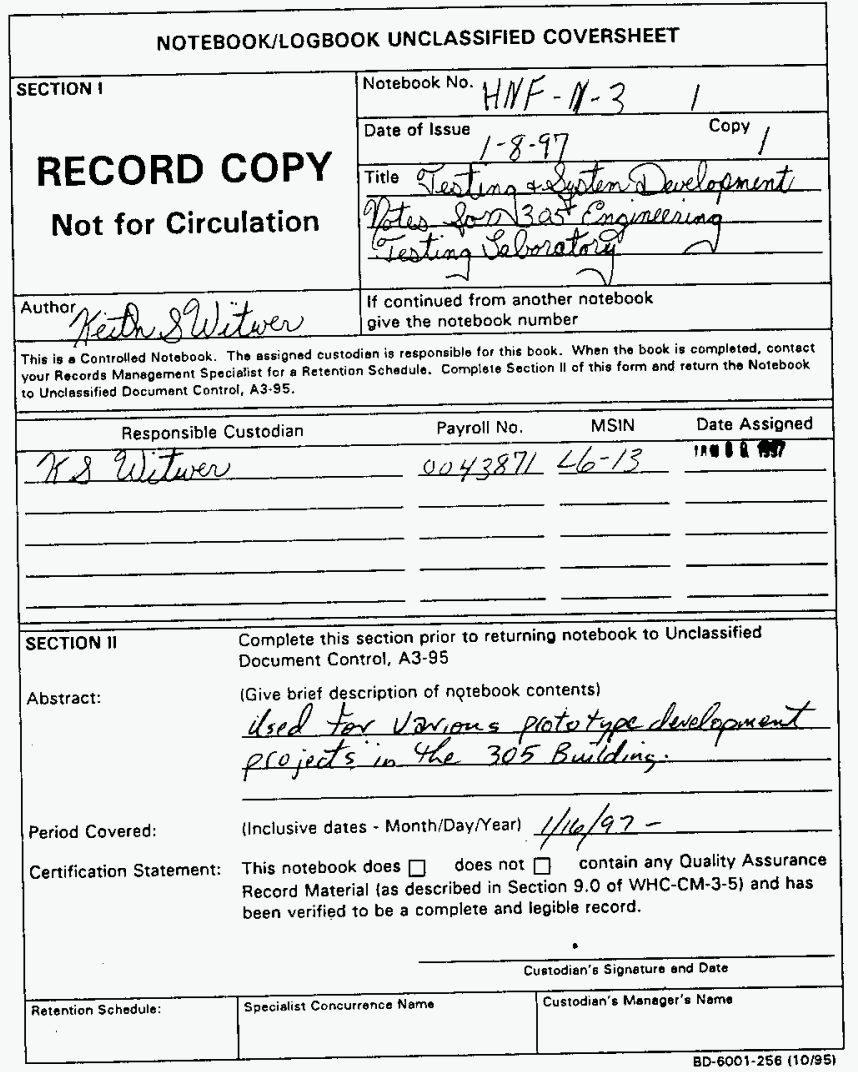


THIS PAGE INTENTIONALLY LEFT BLANK 


\section{INSTRUCTIONS FOR USING NOTEBOOKS/LOGBOOKS}

\section{Please Read Before Making Entries}

1. Original reçords are to be legibly written in reproducible black ink.

2. Notebook/Logbook pages are to be used consecutively. If for any reason a page is skipped, a diagonal line shall be drawn from the top to the bottom of the page. If the entries on a given subject do not completely fill a page, a diagonal line shall be drawn from the last entry to the bottom of the page. These line-outs should be inttialed and dated. If the entries on a given subject extend over several pages which are not consecutive, proper cross-references should be inserted.

3. Notebooks/Logbooks are to be preserved intact. In no case should any pages or part of a page be removed. All extra unused pages shall be : left intact and be firmily secured.

4. No erasures are to occur in the record. Any corrections or changes should be made by drawing one line, leaving the original entry legible. Date and initial. Do not obliterate deletions in any manner.

5. All entries should be dated, including the year. If a given entry extends over more than one page, the date should appear on each page.

6. The person making each entry should sign his/her name at the end of the entry.

7. Entries relating to new ideas, proposals for future experiments, or completed experiments, should receive particular attention. They should be understandable to others, not a mere raminder to the maker. These entries shouTd be reviewed and witnessed by an independent techntcally qualified person who shall date and sign each page of the entry. Additional entries or corrections necessary to clarify the entries to the reviewer shatl be made prior to their signing.

8. Classified information shall not be entered into this notebook.

9. Notebook/Logbook procedures are found in WHC-CM-3-5, Section 12.8 .

ality Assurance $(-3.5)$ and has

Sate

Jame

$\overline{0.6001 .256(10 / 95)}$
10. When Notebooks/Logbooks are completed or no longer needed, complete section II of the Notebook/Logbook Unclassified Cover Sheet. Cantact the records specialist assigned to your organization to obtain concurrence on the record retention schedule. 
THIS PACE INTENTIONALLY LEFT BLANK 


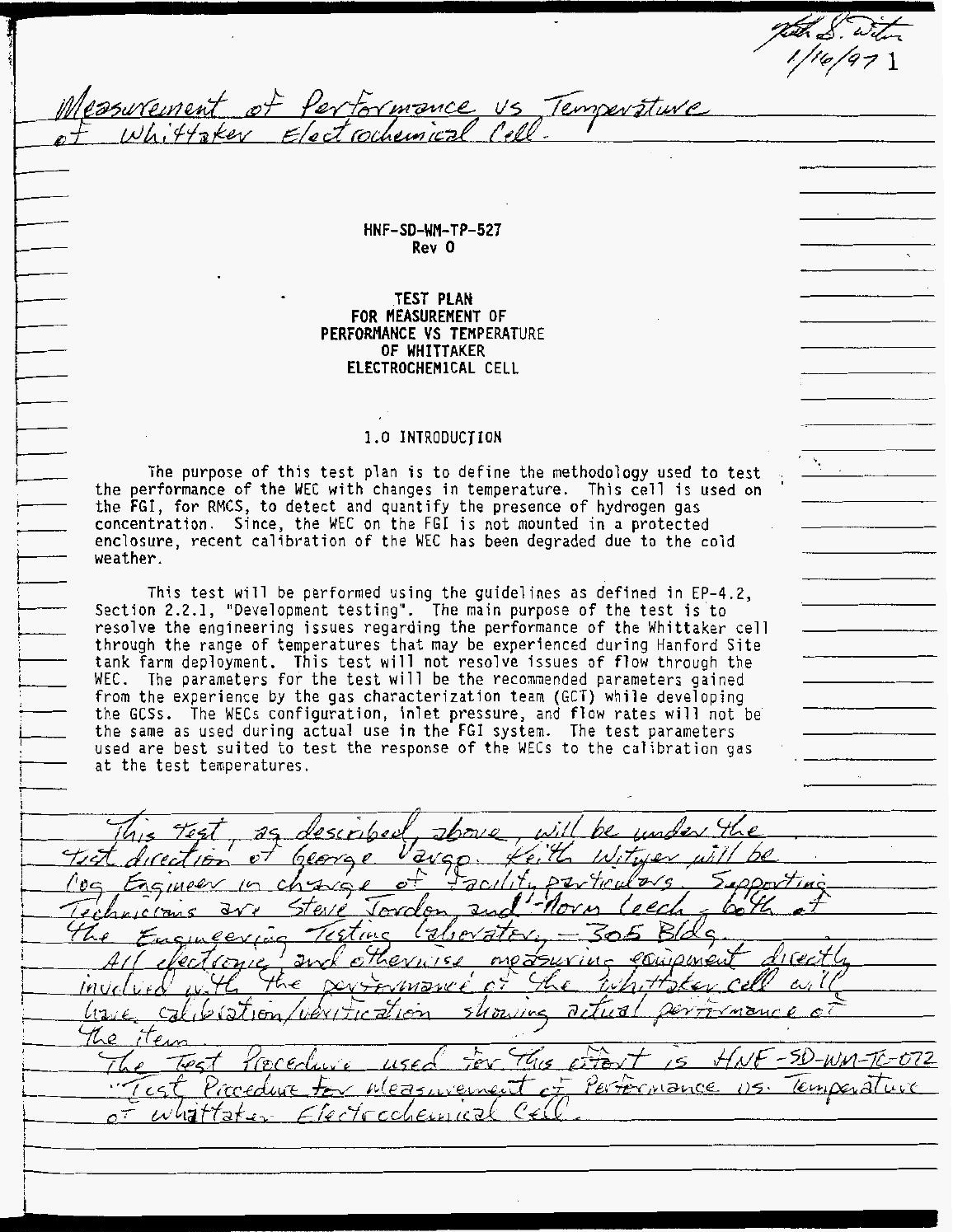


THIS PAGE INTENTIONALLY LEFT BLANK 
$\vec{\pi}+x^{n}+1$ ropumas 7 वराल गयाग

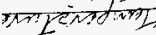
LbhE वृत AP.

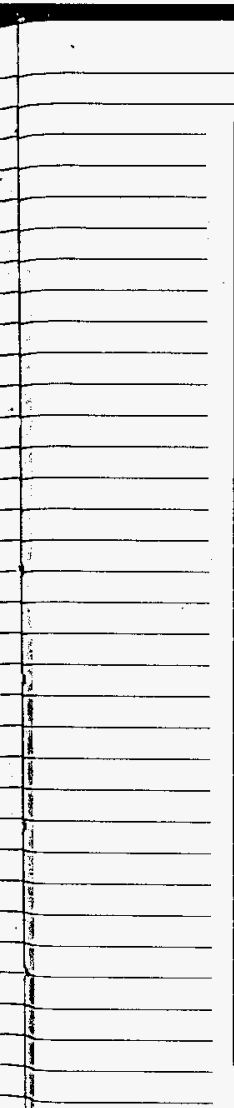

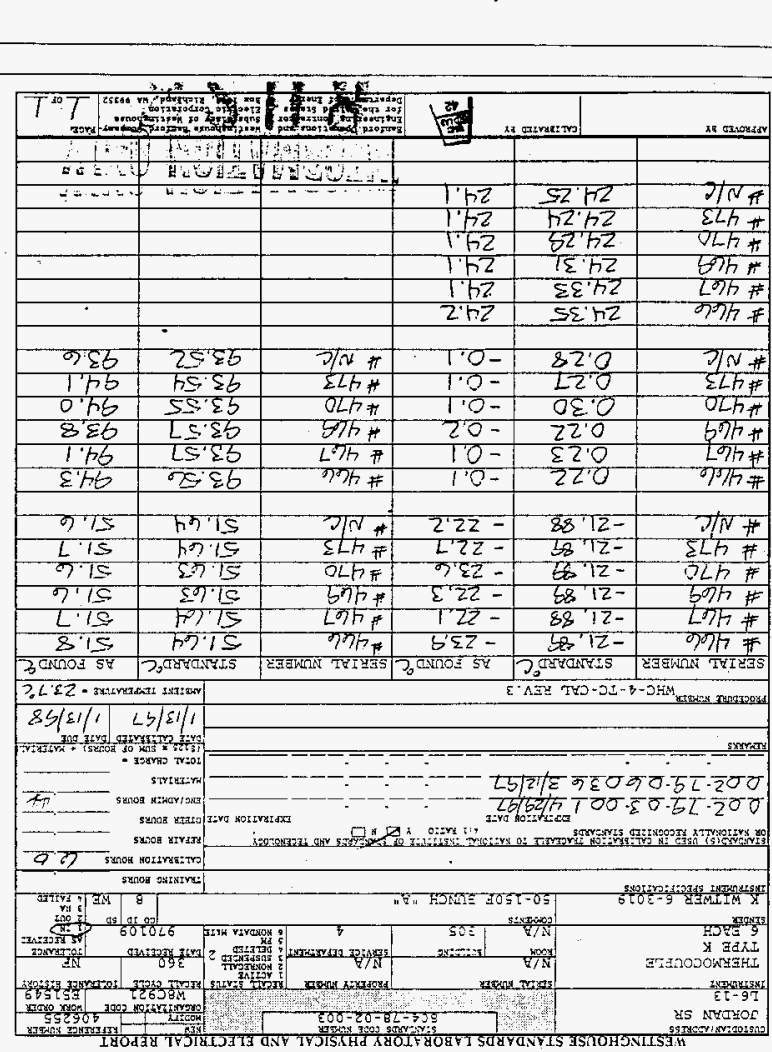

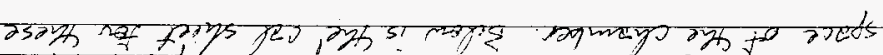

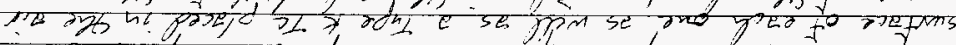

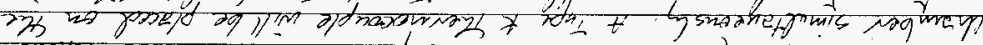

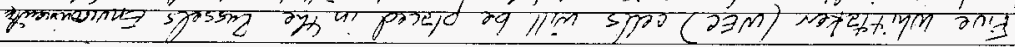

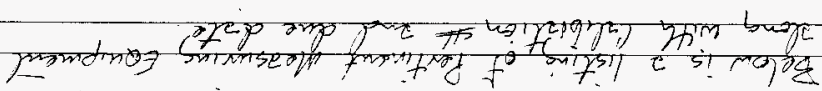


THIS PAGE INTENTIONALLY LEFT BLANK 


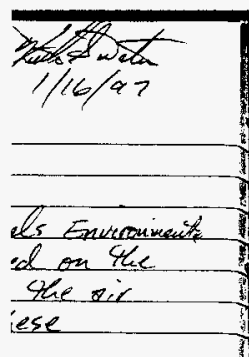

4 Howlett Pickard 9000 savies rearputar with an He 3497 Acquistion Control lant will wowitor and record the Tempersture inputs. (Also possibl the millidit oufouts trom sire Intrinsic Isqutors. An Omeg's CC-505a Temperature Calbrator will be used to verity displaned \& reconded temperatures to the computor. Belfow is the cal sheet tor the calibrator. The HP unit will record entpats from both the WEC's $d$ intriusic isolators. 
THIS PAGE INTENTIONALLY LEFT BLANK 
4

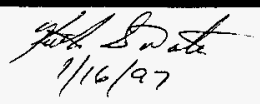

Omega $C_{L}-505$ a cal shect-cont.

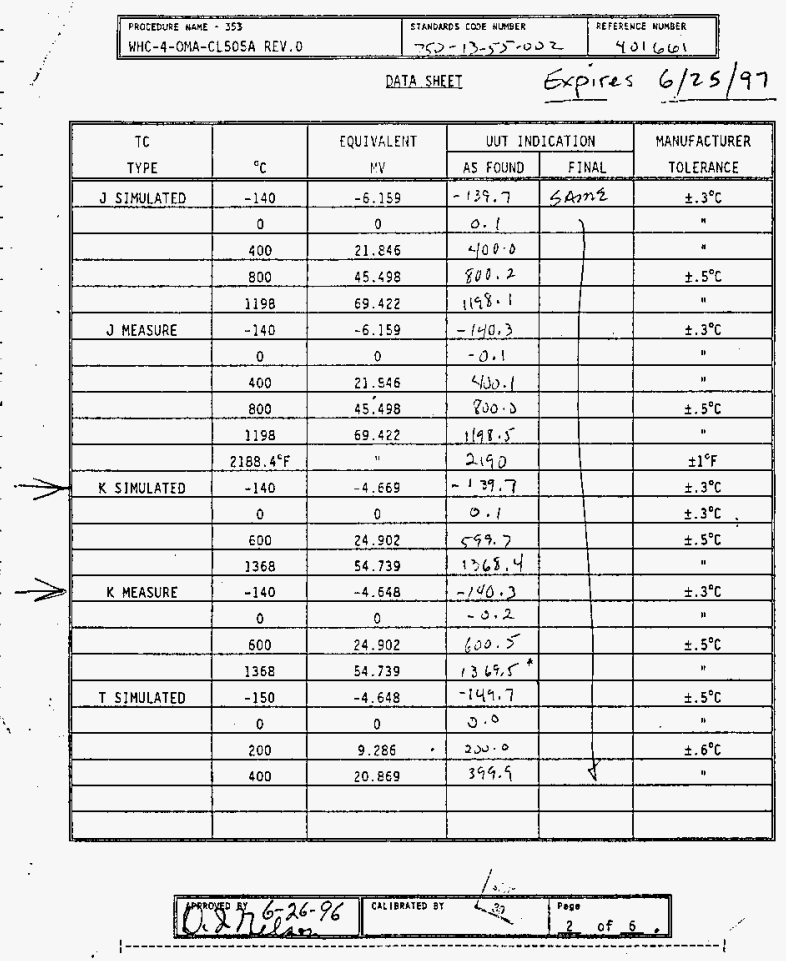


THIS PAGE INTENTIONALLY

LEFT BLANK 


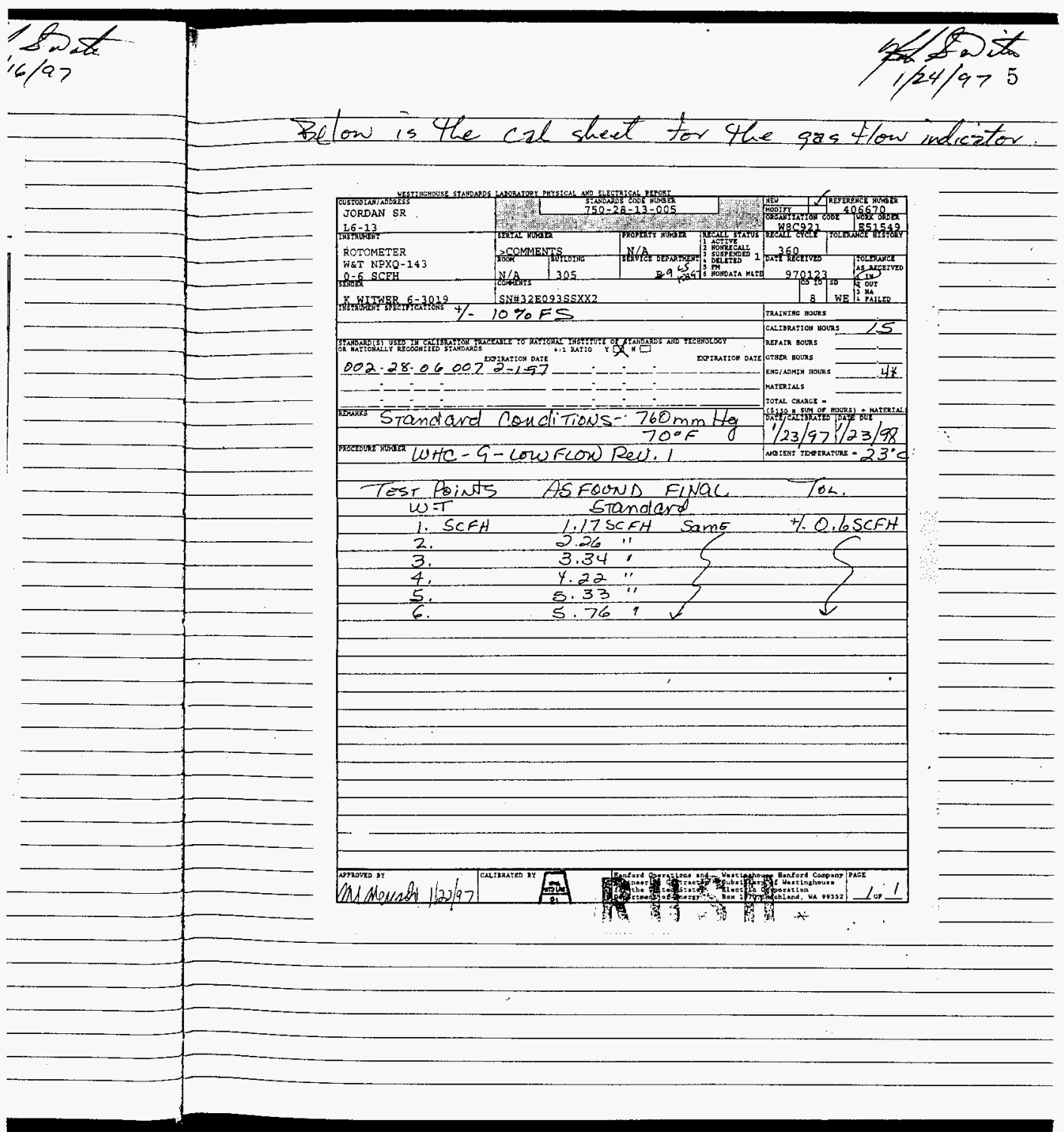


THIS PAGE INTENTIONALLY

LEFT BLANK 
6

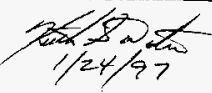

The calibration Gas to be used will be a $1 \%$ dudrogen $499 \%$ air misture the cartitication ot analysis for this perticuler cylindor is quven below.

\section{$01 / 20 / 87^{\circ} \quad 11: 56 \quad 25098764945$

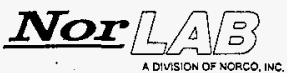

ELO

Q1001

Calibration Gases \& Equipment

\section{CERTIFICATE OF ANALYSIS}

Norco

Kennewick Wzehouse

102 E. Columbia Dr

Kennewick, WA 99336-0000

Cylinder Number: TWCO41277

Po Number: None

Norco Order Number. 720091-00

Component

Hydrogen

Air

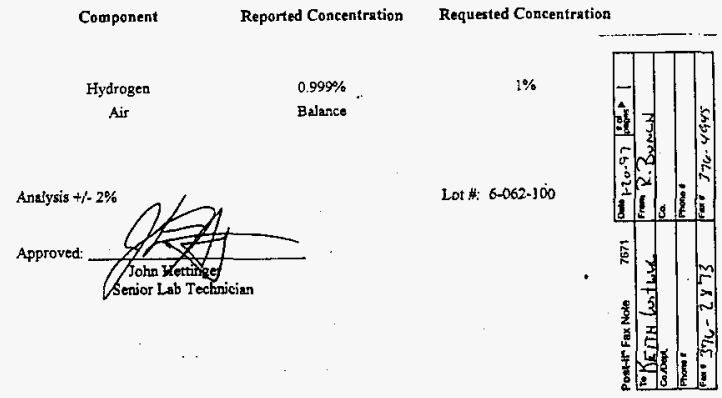

Date: March 4, 1996

Phone (208) 336-i643 $\begin{aligned} & \text { 1121 W. Amity. Boise, ID } 83705 \\ & \text { - Fax (208) 384-1720 - Watts } 1-800-657-6672\end{aligned}$

The carrier gas is pere $\mathrm{N}_{2}$ and docs not require for is suppled with uny centiticition coformation 
THIS PAGE INTENTIONALLY

LEFT BLANK 


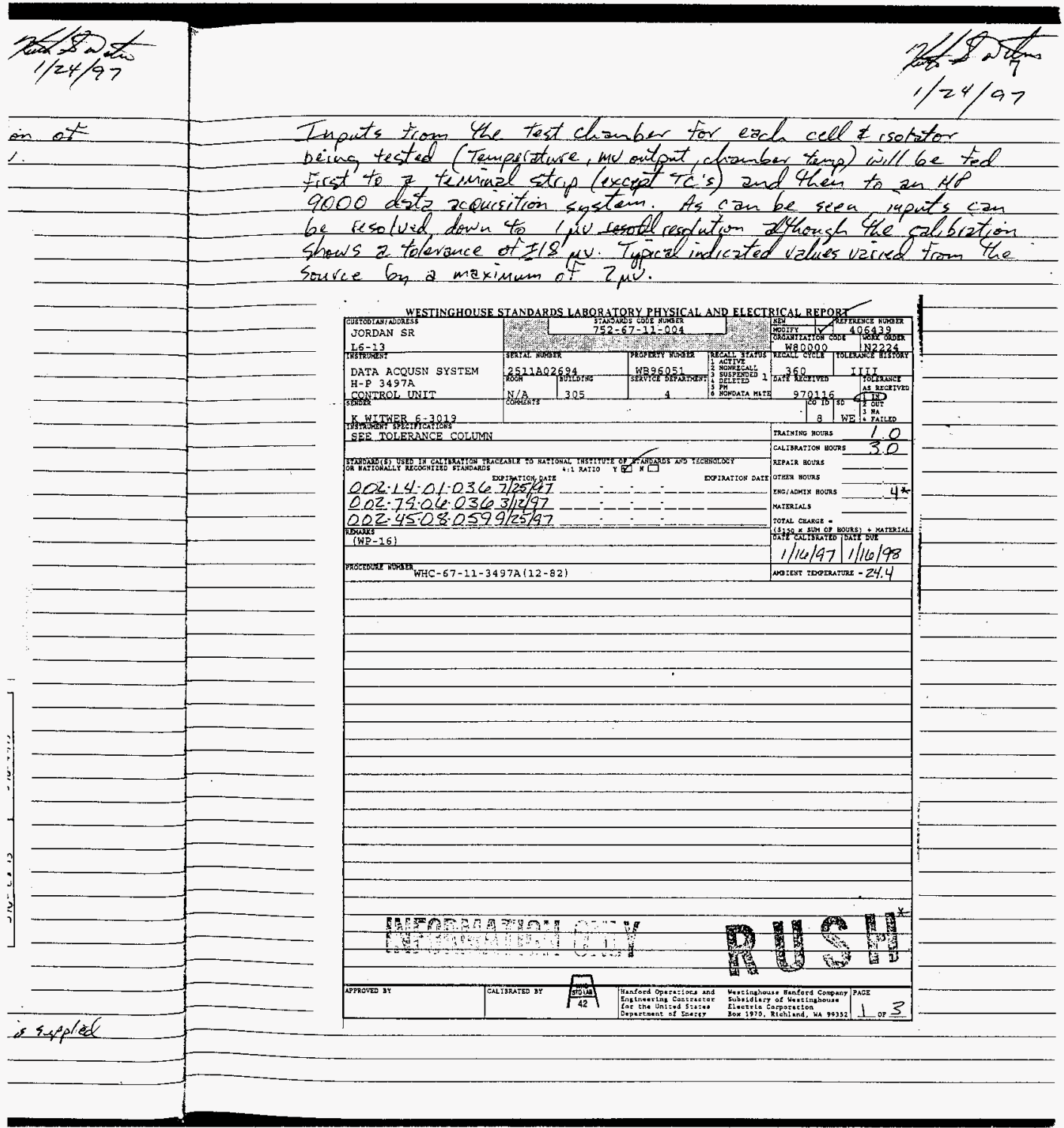


THIS PAGE INTENTIONALLY LEFT BLANK 


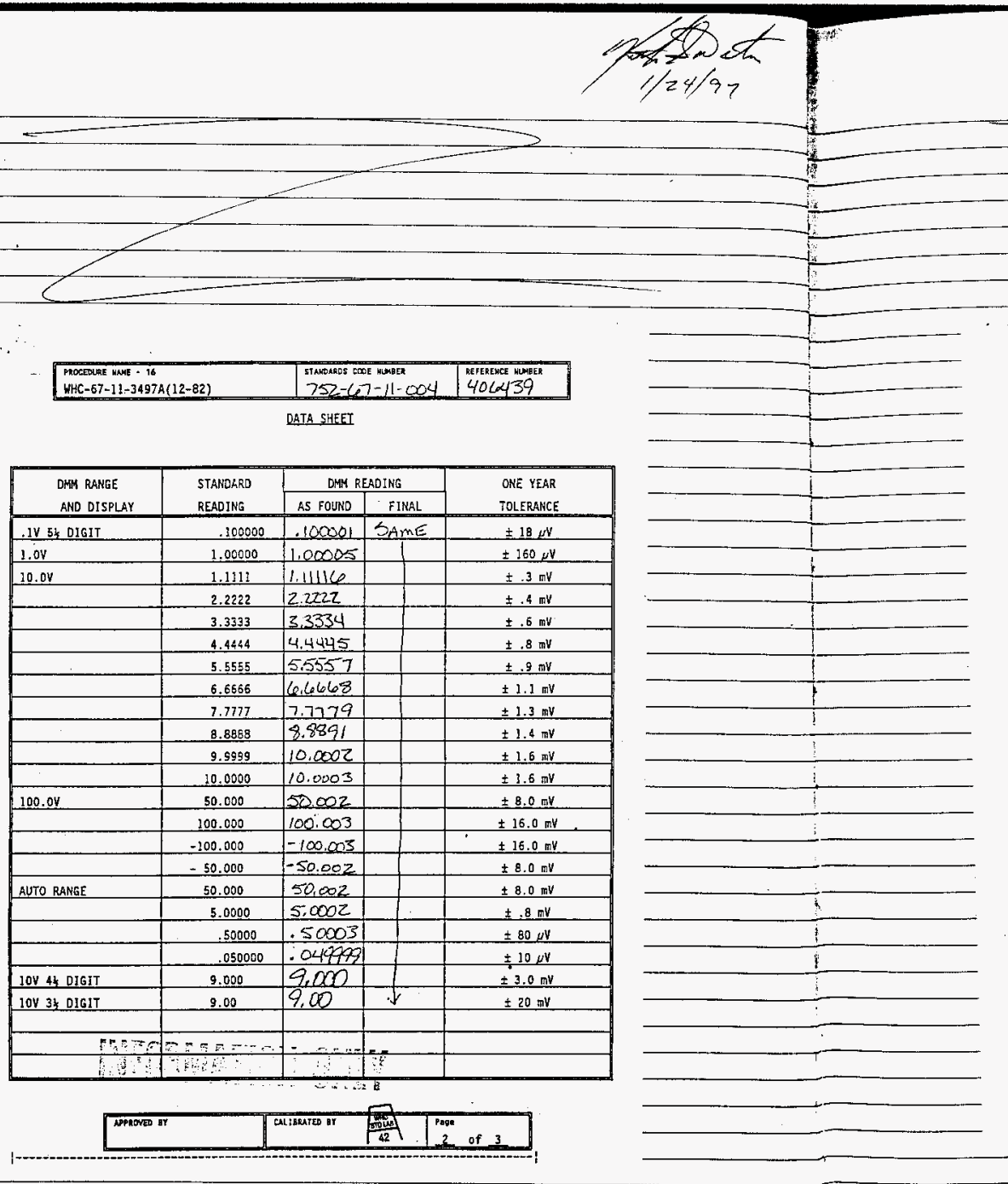


THIS PAGE INTENTIONALLY LEFT BLANK 


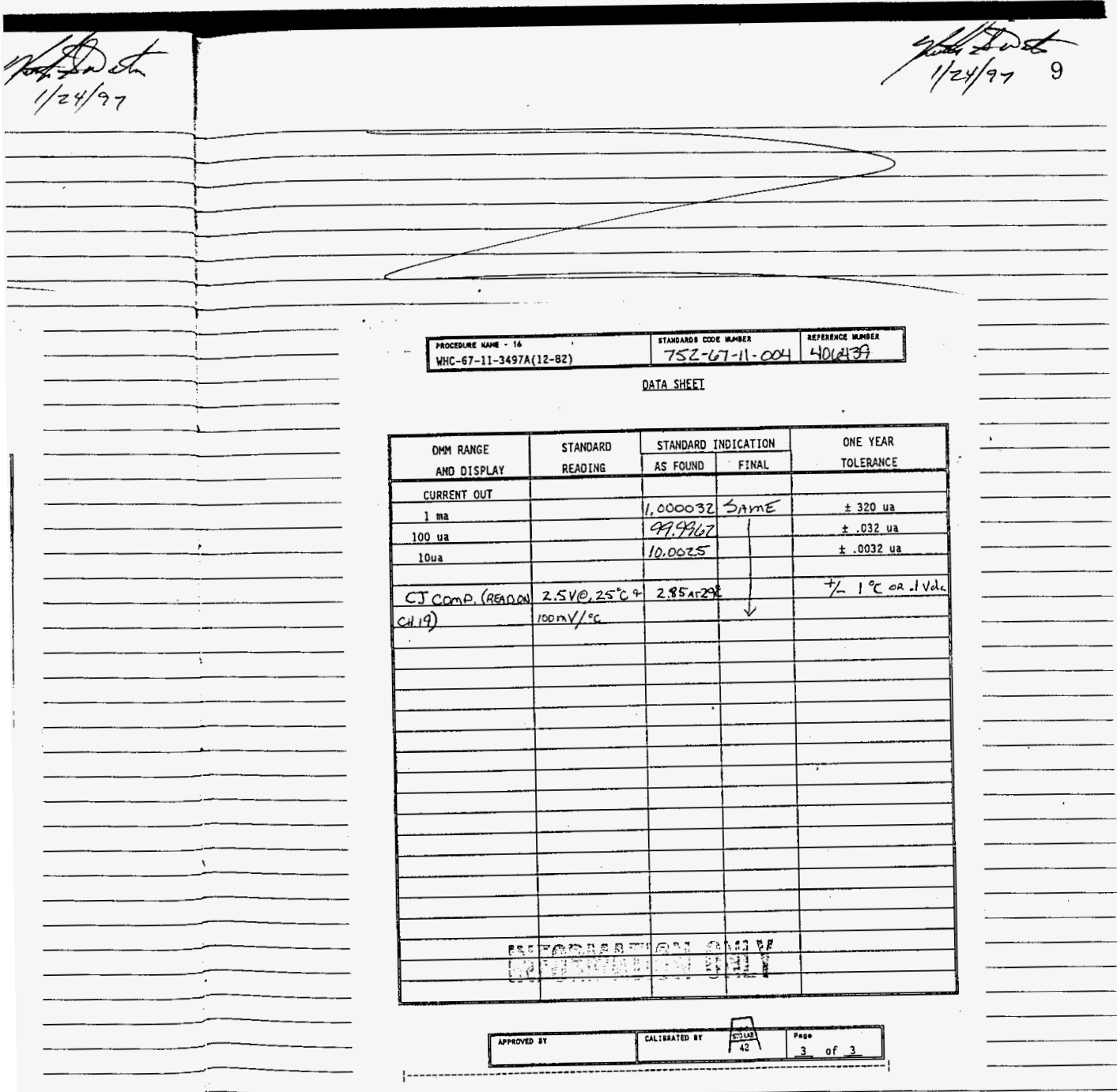


THIS PAGE INTENTIONALLY LEFT BLANK 


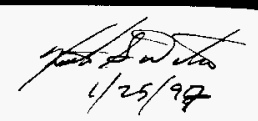

The following table is copied ont of the test procedure and is used heve to summavize test equip used tor testing.

TEST PROCEDURE FOR MEASUREMENT OF PERFORMANCE VS TEMPERATURE WHITTAKER CELL

APPENDIX A: MEASUREMENT AND TEST EQUIPHENT RECORD

\begin{tabular}{|c|c|c|c|c|c|}
\hline Manufacturer & Model & Serial Ho. & $\begin{array}{c}\text { Calibration } \\
\text { Due } \\
\text { Date }\end{array}$ & $\begin{array}{c}\text { Cal ibration } \\
\text { Tracking Code }\end{array}$ & Use Description \\
\hline Qmega & CC505A & 193245687 & $6-25-97$ & $750-15-55-002$ & Cal/Vevify TC inents \\
\hline $\mathrm{HB}$ & $3497 \mathrm{~A}$ & 2511002694 & $1-16-98$ & $752-67-11.004$ & oltain Signal Inputs \\
\hline Fluke & 702 & 6240608 & $12-6-97$ & $750-13-71-001$ & Calibrate Pe Inputs \\
\hline Omeg 2 & Type K T.c. & Varions & $1-13.98$ & $804-78-02-003$ & Monitor Tempersture \\
\hline Posemiont & & & & & Monitor Pressure \\
\hline & & & & & \\
\hline & & & & & \\
\hline & & & & & \\
\hline & & & & & \\
\hline & & & & & \\
\hline & & & & & \\
\hline & & & & & \\
\hline & & & & & \\
\hline & & & & & \\
\hline & & & & & \\
\hline & & & & & \\
\hline & & & & & \\
\hline & & & 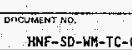 & \begin{tabular}{c|c} 
REvision \\
0
\end{tabular} & $\begin{array}{l}\text { PABENO } \\
\quad 26 \text { OF } 203\end{array}$ \\
\hline
\end{tabular}

Atmospherie pressines have beem obtained on tive seperate days from the 300 Area weather station. On each occascon the obtained values have been within 0.01 PSI. of the indicated value on our. Test Rosemont P.I.T.

* Todans value for atmopheric pressure from weather station, was 14.444 psia \& the Rosemont P.IT. Shows a value of 14.44 psia. 
THIS PAGE INTENTIONALLY LEFT BLANK 


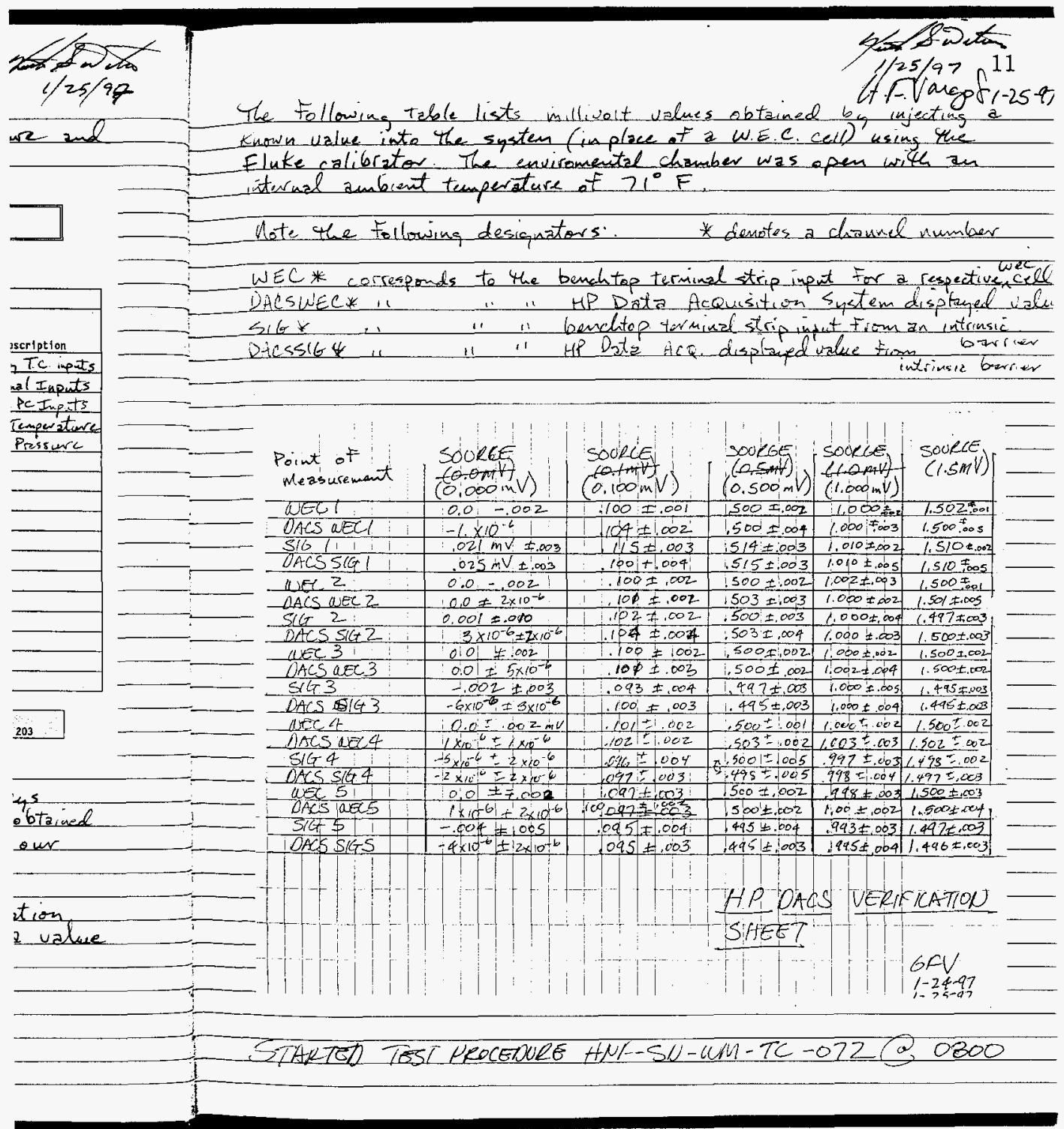


THIS PAGE INTENTIONALLY LEFT BLANK 
12

$$
\begin{aligned}
& \text { G.F. (lougo } \\
& 1-25-97
\end{aligned}
$$

CHANGE \#I TO HROCEAUE HNF-SO-WM-TC.OT2 (SEE APPONOKC EN I) CHANGOD CONFIGULATION OF SYSTEM TO WIRING DIAGRAM BELOW. TITS CHANGEO ADDEO AN ISOLAIION RELAY BETWEEN THE ONTPUT OF WELS है THE INPUT OF DNTRINSL BARRIES. THIS NEUS CONFIGLRATION PROUIDES THE option OF TAKING MEABUREMENTS ON THE WELS NSOLATEO EROM THE ISBS. APPROWOD BY G. FVALIO, OK, KS. WTWER, TK ROGNSON//24/97. G. Filaroo $1-24-900$
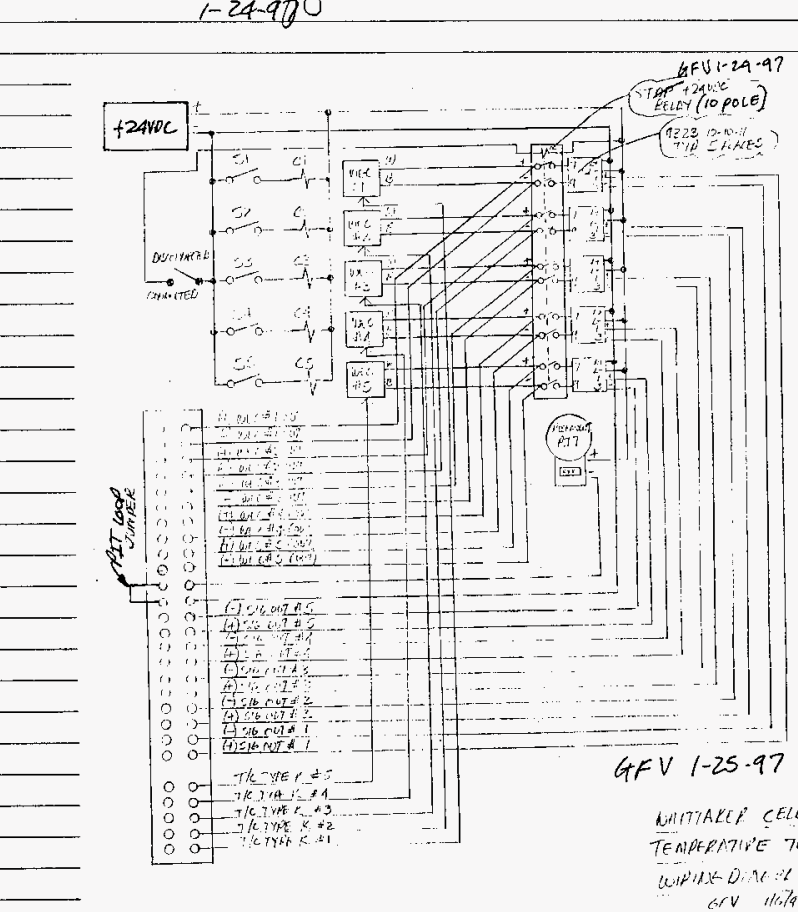
THIS PAGE INTENTIONALLY LEFT BLANK 
Fllougo $)^{n}$

2000 ENC

BELOW. TtS of WELS ह TROUIDES THE m THE ISPS. $24 / 97$.

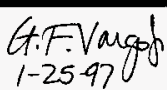

CAANGE \#2 TO PROCOURE HNF-SO-WM-TC OT2 (SEE ADPOONC CN\#2) OAANOEO INTTAL TEMPERATUKE (STEP 7.4) TO T40\% THIS WAS ON FOSTROCTIOOS FLOM TL ROOWWSON WHO WAS IN CONTACT WITH WHITTAKER PER\&ONREL \& E.J. WALDO IN THE WHITTAKEL FACTORY POMONA CA. IHIS NEW STARTING TOMPCRATUKE UAS RECOMMEDED BY WHTTAKER FACTOVY THE PROCEOURE WILL 60 DOWN IN TEMPELATURE, IF CELUSOPERATES CORRECTLY A $+40^{\circ} \mathrm{F}$ OR WILL GO UP IN TEMPERATUKE IF CELC FAILS.

$$
\text { ADPROCE BY: gFVargof } 1 / 25 / 97
$$

CAANGE \#3 TO PROCEDURE HNF SO-WM-TC OP2 (SEE APPGONC ENT3)

CHANGE NUMBER \#3 TO HNF-SD-WM-TC-072

File:whitch-1.pro

CHANGES TO $30 \%, 60 \%, 90 \%$ TEST

NOTE: This change allows the gas header supply line, to the cell, to be charged with the specific concentration of calibration gas $(30 \%, 60 \%$, $90 \%$ before allowing the gas to enter the cell. In this manner the transit time of the gas, from the gas divider to the input of the cell, is minimized.

30\% TEST

After

Step 7.19:

Step 7.30

Step 7.21:

Step 7.19

Step 7.22

60\% TEST

After

Step 7.22

Step 7.29:

Step $7: 30$

Step 7.23:

Step 7.19 ;

Step 7.20

Step 7:22:

Go to Step 7.29 only for 2 minutes

Purge for 2 minutes

Reset and start stopwatch

Take data

Go to to Step $7.27(0 \%$ calibration gas)

Purge for 2 minutes

Purge for 2 minutes

Reset and start stopwatch

Take data

90\% TEST

After

Step 7.22: Go to to Step 7.27 (0\% calibration gas)

Step 7.29: Purge for 2 minutes

Step $7: 30$

Step 7.25:

Step 7.19:

Step 7.20

Step $7: 22$
Purge for 2 minutes

Reset and start stopwatch

Take data

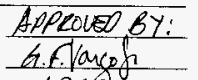
$1-2497$ 


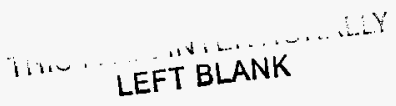


14 Groget.lougon

CAANGE A9TO PROCEDURE HNF-SO-WM-TL-OT2 (SEE APPOOONC EN\#4)

CHANGED PURGE TIME ATSP.7.32 FROM 15 MINUTES TO 2 MINUTES. THIS

ALCOWS THE TEST TIME TO BE REDOCED. THE TKANSPORT TIME OF

THE GAS FROM THE GAS DIVIDEL TO THE SOL WOID UALUE IS

APPROXIMATELY 25 SECONOS. THELF PORE, A LONGEK PURE TIME is NOT

REQuKeD.

$$
\text { APPROEEN: A.F.Varoj 1-25-97 }
$$

$1 / 25 / 99$

K-s.w.

Log notes

Takes 25 seconds for gas to at from divider to WEC cell

After running test, it has been taking 20 to 30 mmates to restore the wec cell and it still shows a higher initial value.

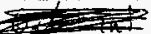

- Approx 12 secs to see indication on WEC cell aster a. qas is injected from solenord value. It 4 akes sloont 25 secerds affar gas is injected from dividor unit. Thes much of this is cell response fime - not ges transport time.

Tishten chambir door Iatch on best teat then shit oft. 14.77PSIA@ cotwued to is 3 were: . 
THIS PAGE INTENTIONALLY

LEFT BLANK 


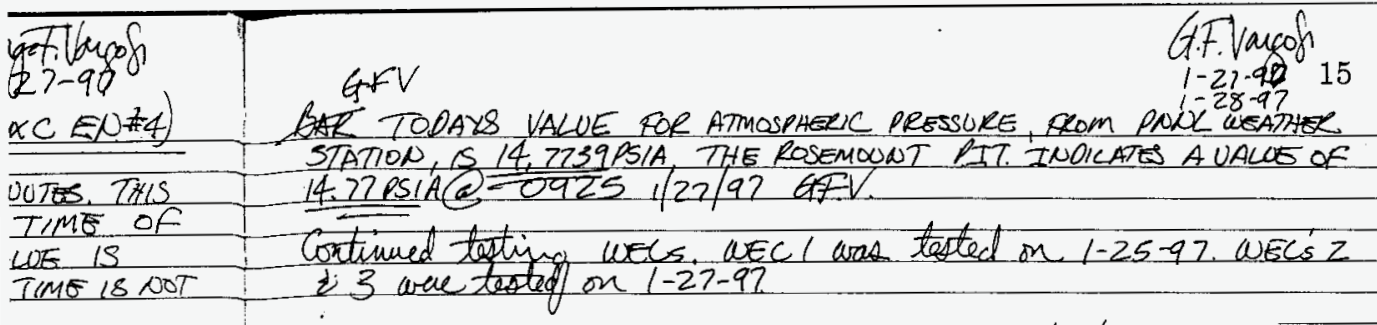

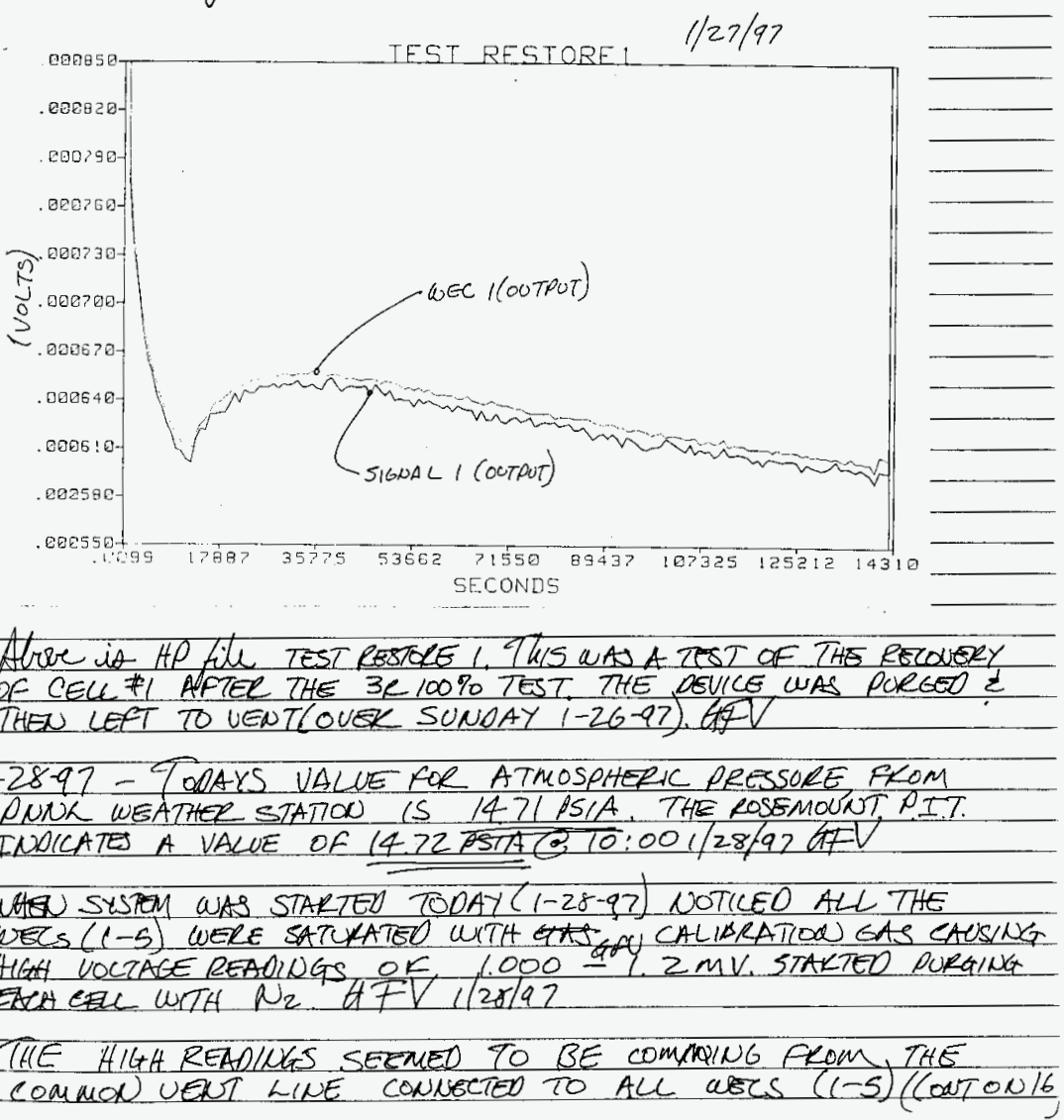


THIS PAGE INTENTIONALLY LEFT BLANK 
16

(CONT FROM 15$)$

ATlarget

CAAANGEO CODFIGULATON FLEM COMMON TO FNOWUOAL VENT ON AL WEC' $(1-5)$. RAD TEST 441 ( WEC $\left.40+40^{\circ} \mathrm{K}, 30 \%, 60 \% 20 \%\right)$ wTIt COMNON UQUT CONTINOED RESTING WEC4 FOR TEST 442

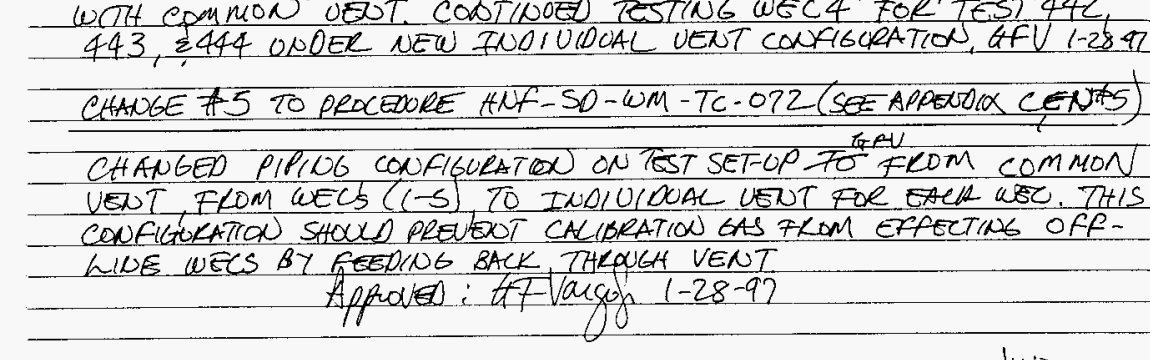

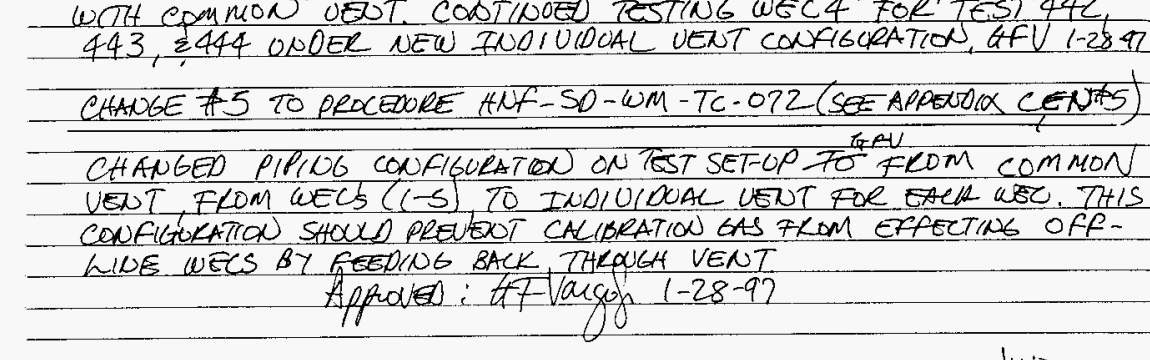

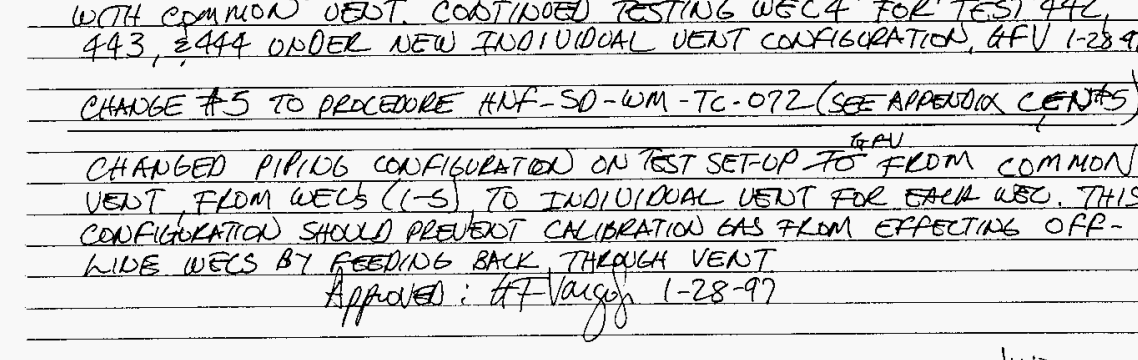

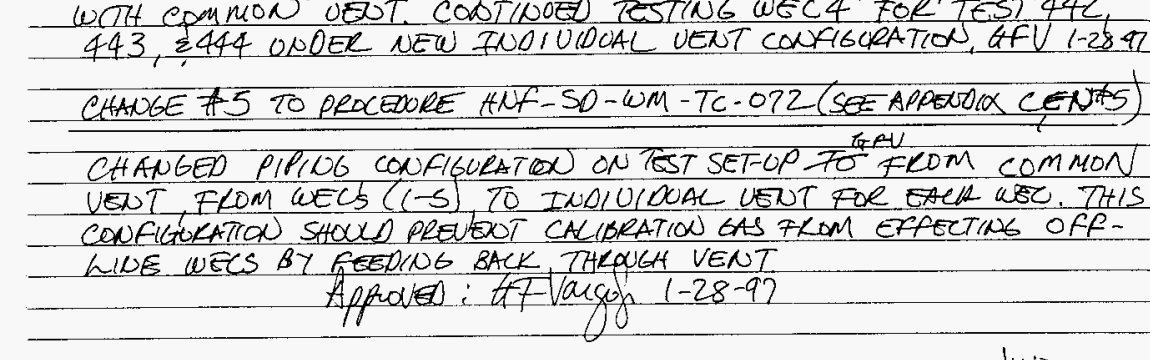

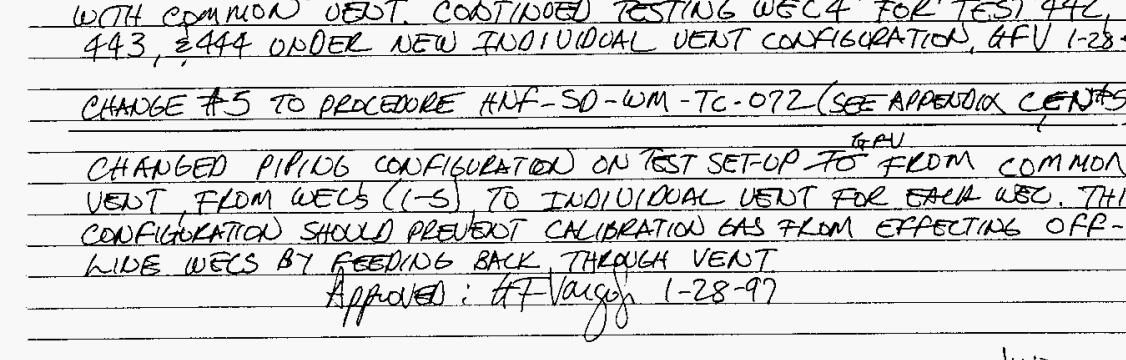

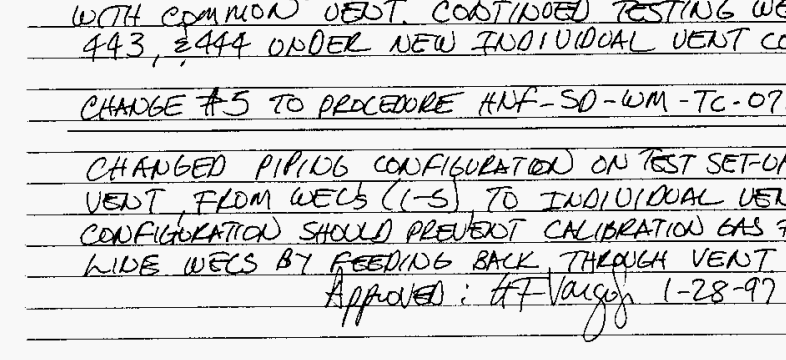

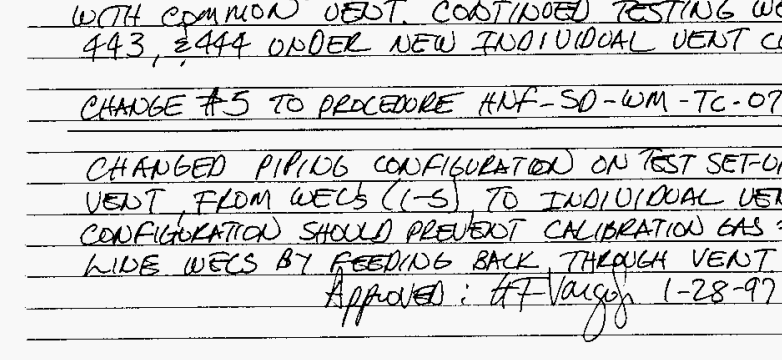

TOOAKS VA WEATHEL STR $06951 / 2$

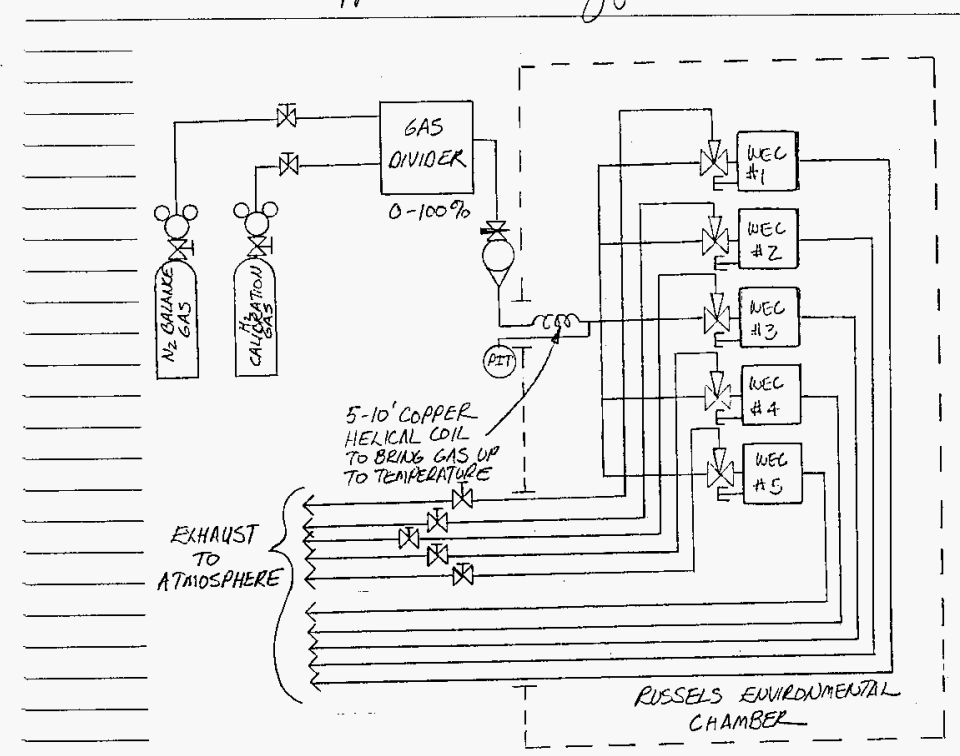

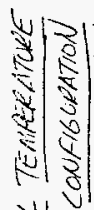

पै

ह 5

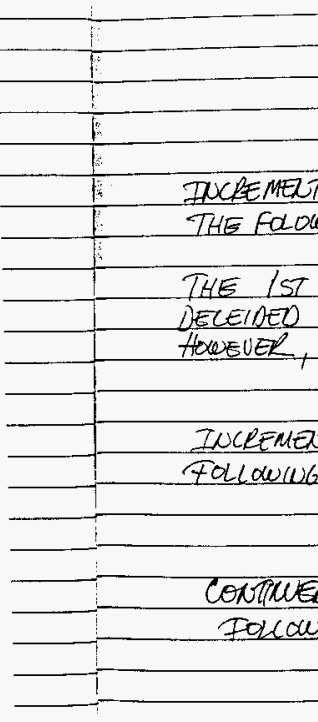

Coxtue COMPLETE of CELLS INCREMEAT CEL FAIL
PASSED 7LCREMSOT Fol cowir 
THW :... INTEW IUNALLY LEFT BLANK 


\section{Vlarged \\ ENT OX $60 \% 20 \%$ TEST 442 3 afV $1-28-9$ Oid Centas) I COMMON सL WEC. 7415 Tins off-}

TEAAXS VALUE FO ATMOSPHERIC PRESSURE IS 14.78 , FROM PNDL

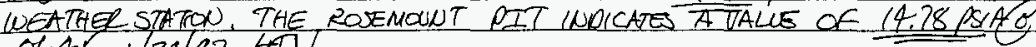
$06451 / 29 / 97$ AFV

COUPLETED TESTING ALL WECSLLS ON 1-28.-97, AT 40 E MATORIT OR CEUS FALLD RATE TEST \&FV-1-29-97. WEC 5 EXCESIUELY WOSY

INCREMETTE TEMPERATUKE TO SQ \% TESTA CEL ZC 100\% ह CEL FAILED ( HP FILE WEC 252). TESTED CELL 4 Q $100 \%$ \& CEL PASSED ( HP FILE WEC 452) GFV-1-29-9?

INCREMESTED TEMPERATURE TO 60\% TEST WECS (1-5) C 100\%WITH THE FOL LOWING RESLTS: WEC I (HP FILE 162): PASSED WEC 2 ( HP FILE 262): PASSEO WEC 3 ( HP FILE 362): FAILED WEL 4 (HP FILE 462): PASSED WEC5 (HP FILE 562): FAILED

\section{GFVargof $1-29-97$}

TNCREMETED TEMPELATORE TO 65 OF TESTED WEC 3C $100 \%$ WITH THE FQDWING RESUTS: WEC 3 (HP FILE 3G3): FAILED $(1 \mu \mathrm{V})$ WEC 3 (HPFILE WEL 364 ): PASSED $(7,3 \mu \mathrm{V})$ THE IST TEST HP FILE WEC 363, FAILED BY lMV E TEST WAS DELEIDED TO BE REPEATED. ZNO TEST, HP FILE WEC 364, PASSED BY $7.3 \mu \mathrm{V}$. HOWEUER, INUTIAL UALUE WAS HISHER $q_{\mu \mathrm{V}}$

$$
\text { GEVargof } 1-29-97
$$

INCREMENTED TEMPERATURE TO $70^{\circ} \mathrm{F}$ TESTED WEC $325(02100 \%$ WITI FOLLOWWG RESUTS: WEC3 (APDATA FILE WEC 372): PASSED WEC 5 (HP DATA FILE WEC 572 ): FAILED 4 tiangof. 1-299?

\section{CONTWED TESTING WECS $(1,2,4)$ @ $100 \%$, $70^{\circ} \mathrm{F}$. RESUTS AS} Ioncws: WEC I (HP DATA FILE 172): PASSED WEC 2 ( HP DATT FILE 272): PASSED WEE $3($ H DATA FILE 322$)$ : PASSED wec 4 $\operatorname{lic}_{29-97}+97$ $\frac{472}{1-29-97} a+4$ AF Vaugen $1-2997$ 7 tougen $(-28.9)$

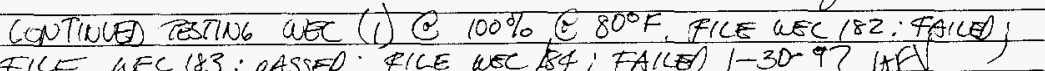
FILE WEC 183: PASSED; FICE WEC LSA: FAME) 1-30-9? IAD ) 
THIS PAGE INTENTIONALLY LEFT BLANK 
HWF-SD-WM-TRP-274, ReV. 0

18

TOPAYS VALUE FOR ATMOSAHERIC PRESEUEE IS 14.58 PSALOM

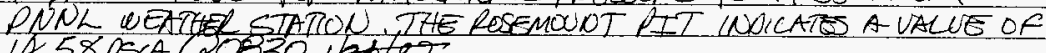
$14.58 \operatorname{PSA} A 30830+1967$.

$1 / 3 / 97$ inal

SEE RESUTTS ON BOTICA OF PALE A FOR ACTIUTIES ON $1 / 3 / 97$ ? CONTWNED berOW:

TODAYS TALUE POE ATMOSPHEAC PRESSURE IS $14.55^{\text {pSSAT }}$

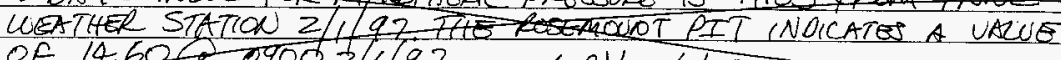
of $14.60009002 / 197$. $P$ PV $2 / 3197$

THE POUOWINS TESTS WELE CONDUCTED ON 1/3197:

WEC I HP FILE WEC 184): FAILEO Q $80^{\circ} \mathrm{F} \mathrm{(100 \% )}$ WEC 2 ( $H Q$ FILE WEC Z82): PASSED E 80\% (100\%) WEC 2 ( HPFILE WEC ZIZ) : PASSED \& $1000^{\circ}$ ( $100 \%$ ) WEC 4 (AP FILE WE 482): PASSED \& $80^{\circ}$ ( $100 \%$ ) WEC 4 ( APFILE WEC 412) : PASSED Q $100 \%(100 \%)$
WEC A ( APFILE WEC 422 ) : PASSED \& $120 \%(100 \%)$

THE FOLWWINB TESTS WEZE CONDUCTEO ON $2 / 1 / 97$ : WEC 2 (APFLE WEC 222): PASSED \& 120\% (100\%)

TODAYS VALUE FOR A TMOSPAERIC PRESUKE IS 14.55 PSIA FROM PNNL WEATHER STATION. FHE ROSEMONOT PIT FNOLATA A A DE DE $14.60 ? 09002 / 1 / 97$.

TODAYS VALOE FOR ATMOSPHCRIC PRESSURE IS 14.70 PSA FKOM PNNL WEATHER STATION. THE ROSEMONNT PIT FNDICATES A UALUE OF 14.7115 IA $09302 / 3 / 9$ ? GfV

CONTINUED TESTING AT $60^{\circ}$ F al aENaT

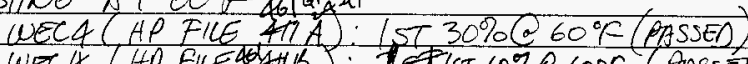

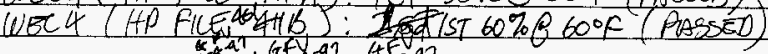

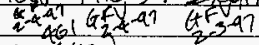
WEA ( $A P$ FUE HAC) :

Page 38 
THIS PAGE INTENTIONALLY LEFT BLANK 
HNF-SD-WM-TRP-274

Rev 0

8.4 ATTACHMENT 4: HNF-SD-WM-TC-072, Rev 0

Page 39 
THIS PAGE INTENTIONALLY LEFT BLANK 

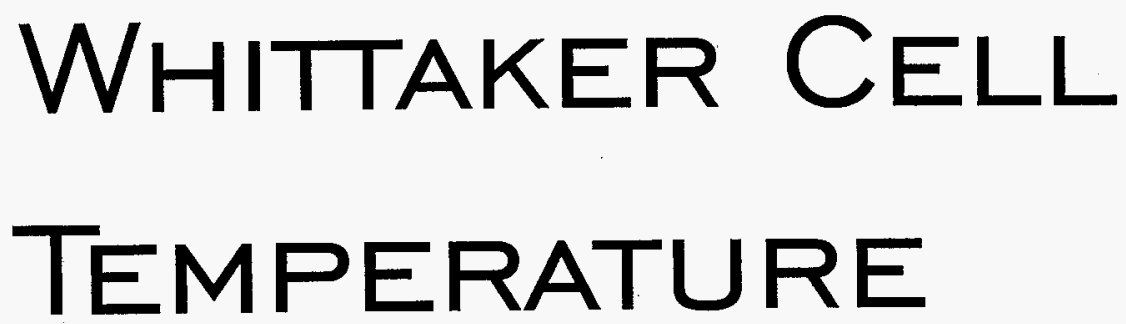

TESTING

Engineering Testing Laborratory - 305 Buillding Numaatec Hinford Comparny 
THIS PAGE INTENTIONALLY LEFT BLANK 
HNF-SD-WM-TRP-274, Rev. 0

\begin{tabular}{|c|c|}
\hline 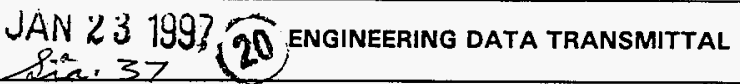 & 1. EDT 619113 \\
\hline
\end{tabular}

2. To: (Receiving Organization) DISTRIBUTION

5. Proj./Prog./Dept./Div.: CHARACTERIZATION 8. Originator Remarks: THIS DOCUMENT IS BEING TRANSMITTED FOR APPROVAL AND RELEASE

11. Receiver Remarks:

3. From: (Originating organization)
REMOTE SENSING AND SAMPLING
EQUIPMENT ENGINEERING
6. Design Authority/ Design Agent/Cog.
Engr::
E.J. WALDO
3. From: (originating Organization) REMOTE SENSING AND SAMPLING 6. Design Authority/ Design Agent/Cog. E.J. WALDO
4. Related EDT No.:

619112

7. Purchase Order Ho.:

$N / A$

9. Equip./Component No.: $N / A$

10. System/Bldg./Facility: $N / A$

12. Major Assm. Dwg. No.: $N / A$

13. Permit/Permit Application No.: N/A TEST CONTROL COPY

14. Required Response Date: $1 / 22 / 97$

\begin{tabular}{|c|c|c|c|c|c|c|c|c|c|c|}
\hline \multicolumn{7}{|c|}{ DATA TRANSMITTED } & \multirow{2}{*}{$\begin{array}{c}\text { (F) } \\
\text { Approval } \\
\text { Dosig- } \\
\text { notor }\end{array}$} & \multirow[b]{2}{*}{$\begin{array}{c}\text { (G) } \\
\text { Reason } \\
\text { for } \\
\text { Trans- } \\
\text { mittal }\end{array}$} & \multirow[b]{2}{*}{$\begin{array}{l}\text { (H) } \\
\text { Origi- } \\
\text { nator } \\
\text { Dispo- } \\
\text { sition }\end{array}$} & \multirow[b]{2}{*}{$\begin{array}{c}\text { (1) } \\
\text { Receiv- } \\
\text { er } \\
\text { Dispo- } \\
\text { sition }\end{array}$} \\
\hline $\begin{array}{l}|A| \\
\text { Itom } \\
\text { No. }\end{array}$ & \multicolumn{2}{|c|}{ (B) Document/Drawing No. } & $\begin{array}{l}\text { (C) } \\
\text { Sheet } \\
\text { No. }\end{array}$ & $\begin{array}{l}\text { (D) } \\
\text { Rev. } \\
\text { No. }\end{array}$ & \multicolumn{2}{|c|}{$\begin{array}{l}\text { (E) Title or Description of Data } \\
\text { Transmitted }\end{array}$} & & & & \\
\hline 1 & \multicolumn{2}{|c|}{ HNF-SD-WM-TC-072 } & ALL & 0 & \multicolumn{2}{|c|}{$\begin{array}{l}\text { TEST PROCEDURE FOR } \\
\text { MEASUREMENT OF } \\
\text { PERFORMANCE VS } \\
\text { TEMPERATURE OF } \\
\text { WHITTAKER } \\
\text { ELECTROCHEMICAL CELL }\end{array}$} & SQ & 1 & 1,2 & \\
\hline & & & & & & & & & & \\
\hline & & & & & & & & & & \\
\hline 16. & & & & & KEY & & & & & \\
\hline \multicolumn{2}{|c|}{ Approval Designator (F) } & \multicolumn{4}{|c|}{ Reason for Transmittal (G) } & \multicolumn{5}{|c|}{ Disposition $(\mathrm{H}) \&(1)$} \\
\hline \multicolumn{2}{|c|}{$\begin{array}{l}\text { E, S, Q, D or N/A } \\
\text { (see WHC-CM-3-5, } \\
\text { Sec. } 12.7 \text { ) }\end{array}$} & \multicolumn{2}{|c|}{$\begin{array}{l}\text { 1. Approval } \\
\text { 2. Release } \\
\text { 3. Information }\end{array}$} & iew & ow. Required\} & \multicolumn{2}{|c|}{$\begin{array}{l}\text { 1. Approved } \\
\text { 2. Approved w/comment } \\
\text { 3. Disapproved w/comment }\end{array}$} & \multicolumn{3}{|c|}{$\begin{array}{l}\text { 4. Reviewed no/comment } \\
\text { 5. Reviewed w/comment } \\
\text { 5. Receipt acknowledged }\end{array}$} \\
\hline
\end{tabular}

\begin{tabular}{|c|c|c|c|c|c|c|c|}
\hline \multicolumn{8}{|c|}{$\begin{array}{l}\text { 17. SIGNATURE/DISIRIBUTION } \\
\text { (Seo Approval Designator for roquired signatures) }\end{array}$} \\
\hline $\begin{array}{l}|G| \\
\text { Rea- } \\
\text { son }\end{array}$ & $\begin{array}{l}(H) \\
\text { Disp. }\end{array}$ & (J) Name & (K) Signature (L) Date, (M) MSIN & $\begin{array}{l}\text { (G) } \\
\text { Res- } \\
\text { son }\end{array}$ & $\begin{array}{l}(H) \\
\text { Disp. }\end{array}$ & \multicolumn{2}{|l|}{ (J) Namo } \\
\hline 1 & $f$ & \multicolumn{2}{|c|}{ Design Authority G.P. Jaf } & 1 & & \multicolumn{2}{|c|}{305 Facility Eng. K.s. Witug $/ /$ ald $16-13 /-2$} \\
\hline & & \multicolumn{2}{|c|}{ Design Agent } & 1 & & \multicolumn{2}{|c|}{305 Facility Mgr. M.J.7pobsigege L6-131r } \\
\hline 1 & 1 & \multicolumn{2}{|c|}{ Cog.Eng. E.J. Waldo Eviswd/z $1 / 2219, \$ 7-12$} & 1 & & \multirow{3}{*}{\multicolumn{2}{|c|}{ 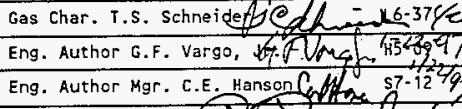 }} \\
\hline 1 & & \multicolumn{2}{|c|}{ 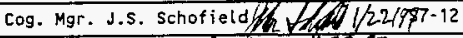 } & 1 & I & & \\
\hline I & 1 & \multicolumn{2}{|c|}{ 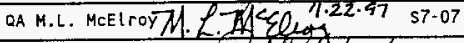 } & 1 & 1 & & \\
\hline 1 & & \multicolumn{2}{|c|}{ 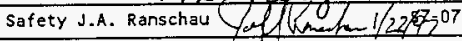 } & 1 & 1 & \multirow{2}{*}{\multicolumn{2}{|c|}{ 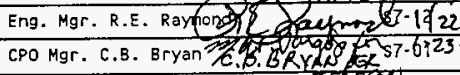 }} \\
\hline & & \multicolumn{2}{|c|}{ Env. } & 1 & 1 & & \\
\hline Signs & & $\log _{a} \frac{1-22}{\text { Dato }}$ & $\begin{array}{l}19 . \\
\text { futhorized Repesentativo Date } \\
\text { for Receiving Organization }\end{array}$ & $\begin{array}{l}20 . \\
\text { s.s. Schofie } \\
\text { Oegign Auth } \\
\text { Cognizant } M\end{array}$ & nager & $\frac{1 / 22 / 7 /}{\text { Dato }}$ & $\begin{array}{l}\text { 21. DOE APPROVAL (if CEgutred) } \\
\text { Ctrl. No. } \\
\text { I] Approved } \\
\text { II Approved w/coments } \\
\text { [] Disapproved w/comments }\end{array}$ \\
\hline
\end{tabular}





\section{TEST PROCEDURE FOR MEASUREMENT OF PERFORMANCE VS TEMPERATURE OF WHITTAKER ELECTROCHEMICAL CELL}

G. F. Vargo, Jr. SGN Eurisys Services Corporation, Richland, WA 99352

U.S. Department of Energy Contract DE-AC06-87Rt-1995-96RL 13200

EDT/ECN: $619113 . \quad$ UC:2070

Org Code: 08E00 Charge Code: N4H3B

B\&R Code: EW3120074 Total Pages: 204

Key Words: Whittaker, chamber, electrochemical, interlock

Abstract: This document is the test procedure to systematically test the Whittaker cells between the temperatures of $-20^{\circ} \mathrm{F}$ and $+120^{\circ} \mathrm{F}$. These sensors are used on the Rotary Mode Core Sampling (RMCS) flammable gas interlock (FGI), to detect and quantify hydrogen gas. This procedure supports the testing, that is being performed, after cold weather calibration attempts, on the whittaker cell, failed.

TRADEMARK DISCLAIMER. Reference herein to any specific commercial product, process, or service by trade name, trademark, manufacturer, or otherwise, does not necessarily constitute or inply its endorsenent, recomendation, or favoring by the United States Government or any agency thereof or its contractors or subcontractors.

Printed in the United States of America. To obtain copies of this document, contact: WHC/BCS Document Control Services, P.O. Box 1970, Mailstop H6-08, Richland HA 99352, Phone (509) 372-2420; Fax (509) 376-4989.
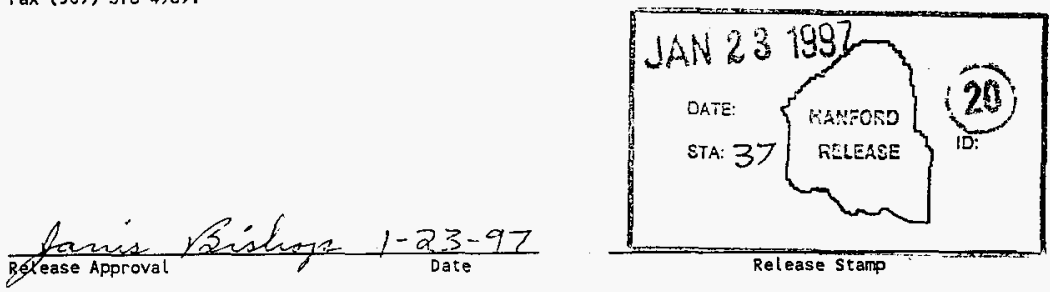

Approved for Public Release 
THIS PAGE INTENTIONALLY LEFT BLANK 
HNF-SD-WM-TC-072
Rev 0

TEST CONTROI GUP

TEST PROCEDURE FOR MEASUREMENT OF

PERFORMANCE VS TEMPERATURE OF WHITTAKER ELECTROCHEMICAL CELL

G. F. Vargo, Jr.

SGN Eurisys Services Corporation, Richland, WA 99352

U.S. Department of Energy Contract DE-AC06-87RL10930 January 1997 
HNF-SD-WM-TRP-274, Rev. 0

TEST PROCEDURE FOR MEASUREMENT OF PERFORMANCE VS TEMPERATURE OF WHITTAKER CELL

TABLE OF CONTENTS

ACRONYMS AND ABBREVIATIONS . . . . . . . . . . . . . . 7

1.0 PURPOSE $/ S C O P E \ldots \ldots \ldots \ldots$

2.0 REFERENCES . . . . . . . . . . . . . . . . 8

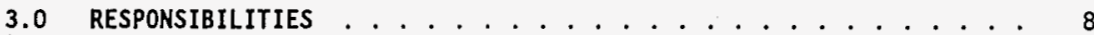

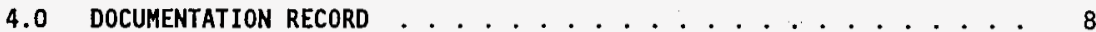

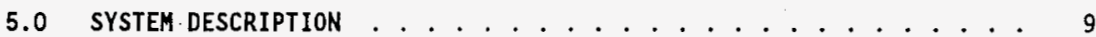

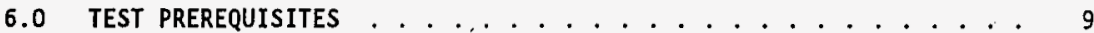

7.0 TEMPERATURE TEST . . . . . . . . . . . . . . . . . . . 10

8.0 APPENDIX A: MEASUREMENT AND TEST EQUIPMENT RECORD . . . . . . 16

9.0 APPENDIX B: DATA RECORD . . . . . . . . . . . . 17

9.1 DATA RECORD SHEET $111 \ldots \ldots \ldots$

9.2 DATA RECORD SHEET $112 \ldots$

9.3 DATA RECORD SHEET $113 \ldots \ldots \ldots$

9.4 DATA RECORD SHEET $114 \ldots \ldots \ldots$

9.5 DATA RECORD SHEET $121 \ldots \ldots$........... 22

9.6 DATA RECORD SHEET $122 \ldots \ldots . \ldots . . . . . . . .23$

9.7 DATA RECORD SHEET $123 \ldots \ldots . \ldots . . \ldots 24$

9.8 DATA RECORD SHEET $124 \ldots \ldots$. . . . . . . . . . 25

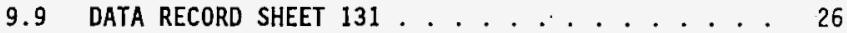

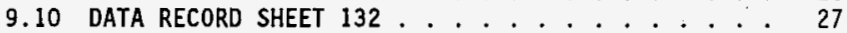

9.11 DATA RECORD SHEET 133 . . . . . . . . . . . . . . 28

9.12 DATA RECORD SHEET $134 \ldots \ldots . \ldots 29$

9.13 DATA RECORD SHEET $141 \ldots \ldots$

9.14 DATA RECORD SHEET $142 \ldots \ldots . \ldots . . . . . . . .31$

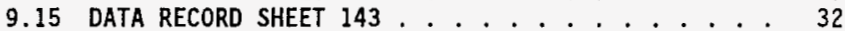

9.16 DATA RECORD SHEET $144 \ldots \ldots . \ldots . . . . . . . .33$

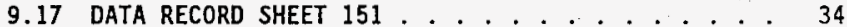

9.18 DATA RECORD SHEET $152 \ldots \ldots \ldots$

9.19 DATA RECORD SHEET $153 \ldots \ldots$........... 36

9.20 DATA RECORD SHEET $154 \ldots \ldots$. . . . . . . . . 37

9.21 DATA RECORD SHEET $161 \ldots \ldots$

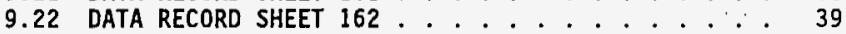

9.23 DATA RECORD SHEET $163 \ldots . \ldots 40$

9.24 DATA RECORD SHEET $164 \ldots \ldots$. . . . . . . . . 41

9.25 DATA RECORD SHEET $171 \ldots \ldots$. . . . . . . . . . 42

9.26 DATA RECORD SHEET $172 \ldots \ldots$. . . . . . . . 43

\begin{tabular}{|c|c|c|}
\hline $\begin{array}{l}\text { DOCUMENT NO } \\
\text { HNF-SD-WH-TC-072 }\end{array}$ & $\begin{array}{l}\text { REVISION } \\
0\end{array}$ & $\begin{array}{l}\text { PAGENO: } \\
2 \text { OF } 203\end{array}$ \\
\hline
\end{tabular}


BNF-SD-WM-TRP-274, Rev. 0

TEST PROCEDURE FOR MEASUREMENT OF PERFORMANCE VS TEMPERATURE OF WHITTAKER CELL

9.27 DATA RECORD SHEET $173 \ldots . . . . . . . . . . .44$

9.28 DATA RECORO SHEET $174 . . . . . . . . . . . . . .44$

9.29 DATA RECORD SHEET 181 ............. 46

9.30 DATA RECORD SHEET $182 \ldots . . . . . . . . .47$

9.31 DATA RECORD SHEET $183 . . . . . . . . . . . .48$

9.32 DATA RECORD SHEET 184 . . . . . . . . . . 49

9.34 DATA RECORD SHEET 212 ............ 51

9.35 DATA RECORD SHEET $213 . . . . . . . . . . . . .52$

9.36 DATA RECORD SHEET 214 ............. 53

9.37 DATA RECORD SHEET $221 . . . . . . . . . .554$

9.38 DATA RECORD SHEET $222 . . . . . . . . . . . .555$

9.39 DATA RECORD SHEET $223 . . . . . . . . . . . . . . .565$

9.40 DATA RECORD SHEET 224 ............. 57

9.41 DATA RECORD SHEET $231 . . . . . . . . . . .58$

9.42 DATA RECORD SHEET $232 \ldots . . . . . . . . . .59$

9.43 DATA RECORD SHEET $233 \ldots . . . . . . . . .60$

9.44 DATA RECORD SHEET $234 . . . . . . . . . . .961$

9.45 DATA RECORD SHEET $241 \ldots . . . . . . . . .62$

9.46 DATA RECORD SHEET $242 . . . . . . . . . . . . . .663$

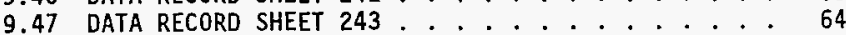

9.48 DATA RECORD SHEET $244 . . . . . . . . . .665$

9.49 DATA RECORD SHEET $251 . . . . . . . . . . . .666$

9.50 DATA RECORD SHEET 252 ............ 67

9.51 DATA RECORD SHEET $253 . . . . . . . . . . . . .68$

9.52 DATA RECORD SHEET 254 ............ 69

9.53 DATA RECORD SHEET 261 ............. 70

9.54 DATA RECORD SHEET 262 ............. 71

9.55 DATA RECORD SHEET $263 . . . . . . . . . . . . .72$

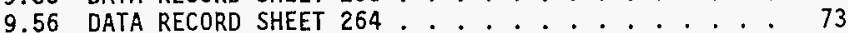

9.57 DATA RECORD SHEET $271 . . . . . . . . . . . .974$

9.58 DATA RECORD SHEET $272 . . . . . . . . . . . .975$

9.59 DATA RECORD SHEET 273 ............. . 76

9.60 DATA RECORD SHEET 274 . . . . . . . . . . . . . 77

9.61 DATA RECORD SHEET $281 \ldots . . . . . . . ., 48$

9.62 DATA RECORD SHEET $282 . . . . . . . . . . .79$

9.63 DATA RECORD SHEET $283 . . . . . . . . . . . .80$

9.64 DATA RECORD SHEET 284 ............. 81

9.65 DATA RECORD SHEET $311 . . . . . . . . . . . .82$

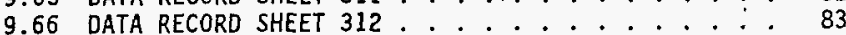

9.67 DATA RECORD SHEET 313 ............. 84

9.68 DATA RECORD SHEET 314 ............. 85

9.69 DATA RECORD SHEET $321 . . . . . . . . . . . . .86$

9.70 DATA RECORD SHEET 322 ............ 87

9.71 DATA RECORD SHEET 323 ............. 88

9.72 DATA RECORD SHEET 324 ............. . 89

9.73 DATA RECORD SHEET $331 . . . . . . . . . . . .990$

9.74 DATA RECORD SHEET 332 ............. . 91

\begin{tabular}{|c|c|c|}
\hline DOCUMENT NO. & REVISION & PAGE NO \\
\hline HNF-SD-KM-TC-072 & 0 & 3 OF 203 \\
\hline
\end{tabular}


HNF-SD-WM-TRP-274, Rev. 0

TEST PROCEDURE FOR MEASUREMENT OF PERFORMANCE VS TEMPERATURE OF WHITTAKER CELL

9.75 DATA RECORD SHEET $333 \ldots \ldots$. . . . . . . . 92

9.76 DATA RECORD SHEET $334 \ldots \ldots 93$

9.77 DATA RECORD SHEET $341 \ldots \ldots$. . . . . . . . . . . 94

9.78 DATA RECORD SHEET $342 \ldots \ldots . \ldots . \ldots 95$

9.79 DATA RECORD SHEET $343 \ldots \ldots . . \ldots . . . . . .96$

9.80 DATA RECORD SHEET $344 \ldots \ldots . \ldots . . \ldots 97$

9.81 DATA RECORD SHEET $351 \ldots \ldots$. . . . . . . . . . . 98

9.82 DATA RECORD SHEET $352 \ldots \ldots 99$

9.83 DATA RECORD SHEET $353 \ldots \ldots$. . . . . . . . 100

9.84 DATA RECORD SHEET $354 \ldots \ldots$. . . . . . . . . . 101

9.85 DATA RECORD SHEET $361 \ldots \ldots . . \ldots . . . . . . .102$

9.86 DATA RECORD SHEET $362 \ldots \ldots$. . . . . . . . . . 103

9.87 DATA RECORD SHEET $363 \ldots \ldots$. . . . . . . . . 104

9.88 DATA RECORD SHEET $364 \ldots \ldots . \ldots 105$

9.89 DATA RECORD SHEET $371 \ldots \ldots$. . . . . . . . 106

9.90 DATA RECORD SHEET $372 \ldots \ldots$. . . . . . . . 107

9.91 DATA RECORD SHEET $373 \ldots \ldots$. . . . . . . 108

9.92 DATA RECORD SHEET $374 \ldots \ldots$. . . . . . . . . . 109

9.93 DATA RECORD SHEET $381 \ldots \ldots$. . . . . . . . 110

9.94 DATA RECORD SHEET $382 \ldots \ldots$. . . . . . . . . 111

9.95 DATA RECORD SHEET $383 \ldots \ldots$. . . . . . . . . . 112

9.96 DATA RECORD SHEET $384 \ldots \ldots \ldots$

9.97 DATA RECORD SHEET $411 \ldots \ldots$. . . . . . . . . . . 114

9.98 DATA RECORD SHEET $412 \ldots \ldots$. . . . . . . . . . 115

9.99 DATA RECORD SHEET $413 \ldots \ldots$. . . . . . . . . 116

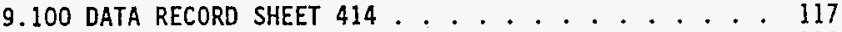

9.101 DATA RECORD SHEET $421 \ldots \ldots$. . . . . . . . . 118

9.102 DATA RECORD SHEET $422 \ldots \ldots$. . . . . . . . 119

9.103 DATA RECORD SHEET $423 \ldots \ldots$. . . . . . . . 120

9.104 DATA RECORD SHEET $424 \ldots \ldots$. . . . . . . . . 121

9.105 DATA RECORD SHEET 431 . . . . . . . . . . 122

9.106 DATA RECORD SHEET $432 \ldots \ldots$. . . . . . . . . 123

9.107 DATA RECORD SHEET $433 \ldots \ldots$. . . . . . . . . . . 124

9.108 DATA RECORD SHEET $434 \ldots \ldots$. . . . . . . . . . 125

9.109 DATA RECORD SHEET $441 \ldots \ldots . . . . . . . . . .126$

9.110 DATA RECORD SHEET $442 \ldots \ldots$. . . . . . . . . . . 127

9.111 DATA RECORD SHEET $443 \ldots \ldots$. . . . . . . . . . . 128

9.112 DATA RECORD SHEET 444 . . . . . . . . . . . . . . 129

9.113 DATA RECORD SHEET $451 \ldots \ldots 130$

9.114 DATA RECORD SHEET $452 \ldots \ldots$. . . . . . . . . . 131

9.115 DATA RECORD SHEET $453 \ldots \ldots$. . . . . . . 132

9.116 DATA RECORD SHEET $454 \ldots \ldots$. . . . . . . . . . . 133

9.117 DATA RECORD SHEET $461 \ldots \ldots \ldots$

9.118 DATA RECORD SHEET $462 \ldots \ldots$. . . . . . . . . . . 135

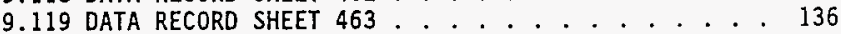

9.120 DATA RECORD SHEET $464 \ldots \ldots$

9.121 DATA RECORD SHEET $471 \ldots \ldots . \ldots 138$

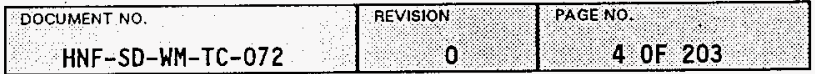


FWF-SD-WM-TRP-274, ReY. 0

TEST PROCEDURE FOR MEASUREMENT OF PERFORMANCE VS TEMPERATURE OF WHITTAKER CELL

9.122 DATA RECORD SHEET 472 . . . . . . . . . . . 139

9.123 DATA RECORD SHEET $473 \ldots . . . . . . . .140$

9.124 DATA RECORD SHEET 474 .............. . . 141

9.125 DATA RECORD SHEET $481 . . . . . . . . . . . . .142$

9.126 DATA RECORD SHEET $482 \ldots . . . . . . . . . . .143$

9.127 DATA RECORD SHEET $483 \ldots . . . . . . . . . .144$

9.128 DATA RECORD SHEET $484 . . . . . . . . . . . .145$

9.129 DATA RECORD SHEET 511 . . . . . . . . . . . . 146

9.130 DATA RECORD SHEET 512 ............ 147

9.131 DATA RECORD SHEET 513 .............. 148

9.132 DATA RECORD SHEET $514 . . . . . . . . . . . . .149$

9.133 DATA RECORD SHEET 521............... 150

9.134 DATA RECORD SHEET 522 ............... 151

9.135 DATA RECORD SHEET $523 \ldots . . . . . . . .152$

9.136 DATA RECORD SHEET $524 \ldots . . . . . . . . . .153$

9.137 DATA RECORD SHEET 531 ............. 154

9.138 DATA RECORD SHEET $532 . . . . . . . . . . . . . .155$

9.139 DATA RECORD SHEET $533 . . . . . . . . . . . .156$

9.140 DATA RECORD SHEET 534 ............. 157

9.141 DATA RECORD SHEET 541.............. 158

9.142 DATA RECORD SHEET 542 .............. . . 159

9.143 DATA RECORD SHEET $543 . . . . . . . . . . . . . .160$

9.144 DATA RECORD SHEET 544 ............ . 161

9.145 DATA RECORD SHEET 551 ............. 162

9.146 DATA RECORD SHEET 552 ............. 163

9.147 DATA RECORD SHEET 553 .............. 164

9.148 DATA RECORD SHEET 554 ............. 165

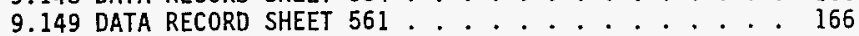

9.150 DATA RECORD SHEET $562 . . . . . . . . . . . . . . .167$

9.151 DATA RECORD SHEET $563 . . . . . . . . . . . . .168$

9.152 DATA RECORD SHEET 564 ............. 169

9.153 DATA RECORD SHEET $571 . . . . . . . . . . .170$

9.154 DATA RECORD SHEET $572 \ldots . . . . . . . .171$

9.155 DATA RECORD SHEET 573 .............. . 172

9.156 DATA RECORD SHEET 574 ............ . 173

9.157 DATA RECORD SHEET $581 . . . . . . . . . . . . . .174$

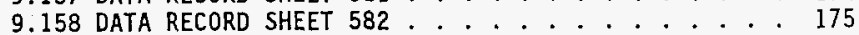

9.159 DATA RECORD SHEET $583 . . . . . . . . . . . . .176$

9.160 DATA RECORD SHEET 584 . . . . . . . . . 177

10.0 APPENDIX C: EXCEPTION RECORD . . . . . . . . . . . 178

11.0 APPENDIX D: TEST RECORD . . . . . . . . . . . . . 178

12.0 APPENDIX E: GAS BOTTLE RECORD ............... 180

DOCUMENT NO

HNF-SD-WM-TC-072 $\mid \begin{aligned} & \\ & \text { H }\end{aligned}$ 
(FinaT Procedure Acceptance Sheet) . . . . . . . . 181 (Test Plan for Measurement of Performance vs Temperature of Whittaker Cell) . . . . . . . . . . . . 182 
HNF-SD-WIM-TRP-274, Rev. 0

TEST PROCEDURE FOR MEASUREMENT OF PERFORMANCE VS TEMPERATURE OF WHITTAKER CELL

\section{ACRONYMS AND ABBREVIATIONS}

ETL Engineering Testing Laboratory

$T / C \quad$ Thermocouple

WEC Whittaker Electrochemical Cell

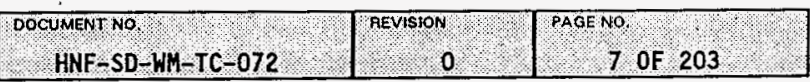




\subsection{PURPOSE/SCOPE}

This procedure will systematically evaluate the performance versus temperature of the Whittaker electrochemical cell in accordance with HNF-SDWM-TP-527. See Section 2.0 of this document. chamber.

This test will be performed in the $305 \mathrm{ETL}$ using the environmental test

\subsection{REFERENCES}

2.1 HNF-SD-WM-TP-527, Test Plan for Measurement of Performance vs. Temperature of Whittaker Electrochemical Cell, Rev. 0, SGN Eurisys Services Corporation, Richland, WA 99352, January 1997.

2.2 WHC-SD-WM-SAD-035, A Safety Assessment of Rotary Mode Core Sampling in Flammable Gas Single Shell Tanks, Rev OA, LoS Atamos National Laboratory, Los Alamos, New Mexico, August 1996.:

\subsection{RESPONSIBILITIES} procedure:

The following personnel will be required for the performance of this

- Test Director: The engineer assigned responsibility for the performance of this test.

- Test Personnel: One(1) or more engineers and/or technicians assigned to assist the Test Director during the performance of this test.

The key personnel designated to perform this test are identified in Section 3.1.1.7 of HNF-SD-WM-TP-527. See Attachment 2 of this document.

\subsection{DOCUMENTATION RECORD}

The appendices of this procedure shall be the document record. They are designated as follows:

- $\quad$ APPENDIX A: MEASUREMENT AND TEST EQUIPMENT RECORD

- APPENDIX B: DATA RECORD

- APPENDIX C: EXCEPTION RECORD

- APPENDIX D: TEST LOG RECORD

- APPENDIX E: GAS BOTTLE RECORD

These appendices designations are as defined in HNF-SD-WM-TP-527. See Attachment 2 of this document.

\begin{tabular}{|r|r|r|}
\hline DOCUMENT NO. & REVISION & PAGENO \\
HNF-SD-WM-TC-072 & 0 & $80 F \quad 203$ \\
\hline
\end{tabular}

\section{$46-1$}




\subsection{SYSTEM DESCRIPTION}

this document.

Reference Section(s) 1.0 and 2.0 of HNF-SD-WM-527. See Attachment 2 of

\subsection{TEST PREREQUISITES}

6.1 Prior to initiation of testing, the following conditions shall be verified:

6.1.1 The job hazards analysis(JHA), for performance activities, for this test is $305 \mathrm{ETL}$, has been performed and all personnel have signed the record sheet.

Verified. by:

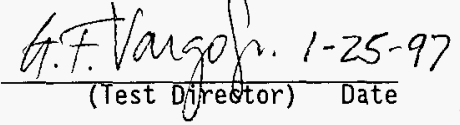

6.1.2 The information for a11 instruments and test equipment have been recorged in APPENDIR $A$.

Verified by: $\frac{G . F \text {. } M G 0) 1-25-97}{\text { (Test Dirgctor) Date }}$

6.1.3 The information for all gas bottles have been recorded in APPENDIX $E$.

verified by: $\frac{67 . F \cdot \operatorname{lacho} 1-25-97}{\text { (Test Diregtod) }}$

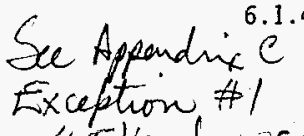

6.1 .4

A.F.Vargor 1-25-97

Sa Aptoundac Excation $\$ 5$ G.t. vagon $1-28.97$
The test apparatus has been configured, connected, and tested, according to FIGURES 1 and 2 of HNF-SD-WM-TP527 in the environmental test chamber, the $T / C$ readout for the chamber is operational, and the door of the chamber has been closed. See Attachment 2 of this document.

Verified by:

$$
\frac{4.7 \text { Vagof } 1-2597}{\text { (Test qurector) Date }}
$$

The atmospheric pressure has been verified by calling the Hanford weather service(373-2716) in the 300 area.
DOCUMENT NO

HNF-SD-WH-TC-O72
REVISION

0

PAGENO.

9 OF 203

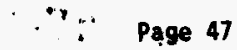




\section{TEST PROCEDURE FOR MEASUREMENT OF PERFORMANCE VS TEMPERATURE OF} WHITTAKER CELL

ROSGMO0NT LEAD: 14.44 PSIA

Atmospheric pressure: $\frac{14.444 \text { SSIA } 0620 /-25.97}{\text { Reading Time Date }}$

verified by: $\frac{4 . t \text { Vangoh } 1-25-97}{\text { (Test Dofedetor) Date }}$

6.2 Prior to initiation of testing, the following equipment shall be available for use:

\subsubsection{Two(2) calibrated microvoltmeter(s), capable of} measuring circuit voltage to $.1 \mathrm{mV}+/-.01 \mathrm{mV}$. Record in Appendix A.

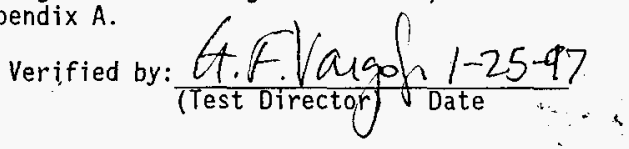

NOTE: The 305 ETL Hewlett Packard (HP) microvolt data acquisition system will be used as the microvoltmeter readout device capable of measuring circuit voltage to $.1 \mathrm{mV}+/-.01 \mathrm{mV}$. The calibrated microvoltmeters will be used to verify the HP voltage readings.

6.2.2 $T / C$ readout device capable of reading Type $K T / C$ to $+1-3.96^{\circ} \mathrm{F}$. Record in Appendix A.

verified by: $\frac{\text { Af. F Mgo , }(-25-97}{\text { (Test Diredtor) Date }}$

NOTE: The $305 \mathrm{ETL}$ Hewlett Packard (HP) T/C data acquisition system will be used as the readout device capable of reading Type $K T / C s$ to $+/-$ $3.96^{\circ} \mathrm{F}$. Furthermore, the 305 ETL Omega temperature calibrator will be used to verify the HP temperature readings.

\subsection{TEMPERATURE TEST}

7.1 If any step in this section cannot be successfuliy performed or results in an abnormal condition, then record a description of the condition in Appendix $C$.

7.1.1 For each discrepancy recorded, enter an identifying number in the "EXCEPTION NUMBER" column of Appendix $C$.

\begin{tabular}{|c|c|c|}
\hline $\begin{array}{l}\text { DOCUMENT NO } \\
\text { HNF-SD-WM-TC-OT2 }\end{array}$ & REVISION & $\begin{array}{lll}\text { PAGENO } & \\
10 & \text { OF } & 203\end{array}$ \\
\hline
\end{tabular}

\section{$47-1$}




\section{TEST PROCEDURE FOR MEASUREMENT OF PERFORMANCE VS TEMPERATURE OF WHITTAKER CELL}

7.1.2 Reproduce Appendix $C$ as required, and attach the additional pages to this procedure, to record all discrepancies noted during testing.

WARNING: This test involves the use of bottled gas under high pressure. Operating personnel must be continuously on the alert for leaks from any gas lines, fittings, or devices. Any leaks are to be corrected immediately by appropriate action.

7.2 Ensure that the five(5) 3-way solenoid valves(V6,V7, V8,V9,V10) are in the de-energized ("VENT") position by opening the five(5) solenoid control switches(S1,S2,S3,S4,S5).

NOTE: When the 3-way solenoid vaive(s) $\left(V_{6}, V 7, V 8, V 9, V 10\right)$ are DE-ENERGIZED the gas header is 1 ined up VENT TO ATMOSPHERE(VENT) through the manual vent valve(s)(V11,V12,V13,V14,V15).

When the 3-way solenoid valve(s)(V6,V7,V8,V9,V10) are ENERGIZED the gas header is lined up to the WHITTAKER CELL(WEC).

7.3 Ensure that all the manual vent valves (V11,V12,V13,V14,V15) from the five(5) WECS, are in the closed position by turning each valve operator, on each valve, clockwise and by observing no gas flow on flawmeter(FI).

7.4 Energize the environmental test chamber and begin to heat up to

$120^{\circ} \mathrm{F}$. When temperature is reached and stabilized go to Step 7.5
Sce Abjeind 4.5 Ensure power is de-energized to the +24 Vdc system power supply(PS C Exceftion 2 1) with a zero energy check using a test meter.

7.6 Connect a microvolt readout device(HP microvolt data acquisition system) to the output terminals terminating the $(+)$ and $(-)$ leads of the Whittaker cell under test. Plus $(+)$ lead of microvoltmeter device connects to $(+)$ lead from the cell and $(-)$ lead of the microvolt device connects to the $(-)$ lead of the cell.

7.7 Connect a microvolt readout device(HP microvolt data acquisition system) to the output terminals terminating the $(+)$ and $(-)$ leads of the respective 9323/10-10-11 Stahl intrinsic voltage isolating repeater, of the Whittaker cell under test. Plus (t) lead of microvoltmeter device connects to $(+)$ lead from the barrier and $(-)$ lead of the microvolt device connects to the $(-)$ lead of the barrier.

\begin{tabular}{|r|r|r|}
\hline DOCUMENT NO & AEVISION & PAGENO \\
HNF-SD-WM-TC-072 & 0 & 11 of 203 \\
\hline
\end{tabular}




\section{TEST PROCEDURE FOR MEASUREMENT OF PERFORMANCE VS TEMPERATURE OF WHITTAKER CELL}

7.8 Connect the $T / C$ readout device(HP $T / C$ data acquisition system) to the $T / C$ attached to the Whittaker cell under test.

7.9 Energize the $+24 \mathrm{Vdc}$ power suppiy(PS 1) to the system. Verify live power by check with a test meter.

7.10. Ensure that the gas divider(GI) is selected to the $0 \%(100 \%$ balance gas) on the selector switch.

7.11 Ensure that the balance gas is on by opening the bottle stop 'valve(VI) and observing the bottle pressure and the header output pressure past the regulator(R1).

7.12 Ensure that regulated balance gas pressure is reading 20 psi. by adjustment of the regulator(R1). Clockwise(CW) rotation of the adjustment knob increases the pressure, counter clockwise(CCW). decreases the pressure.

7.13 Ensure that the regulated balance gas is energized to the gas divider by opening of the balance gas isolation valve(V3) operator in the CCW direction.

7.14 Ensure that the calibration gas is on by opening the bottle stop valve(V2) and observing the bottle pressure and the output pressure past the regulator(R2).

7.15 Ensure that regulated calibration gas pressure is reading between 22 and 24 psi. by adjustment of the regulator(R2). CW rotation of the adjustment knob increases the pressure, CCW decreases the pressure.

7.16 Ensure that the regulated calibration gas is energized to the gas divider by opening of the calibration gas isolation valve(V4) operator in the CCW direction.

7.17 Ensure that the 3 way solenoid valve(V6,V7,V8,V9,V10), to wittaker cell under test, is in venting to atmosphere("VENT") position by opening the respective manual vent isolation valve(V11,V12,V13,V14,V15) operator, in the CCW direction, and by closing(CW), and then re-opening(CCW). When valve is closed there should be a momentary loss of flow observed on flow meter(FI). Adjust the needle flow valve(V5) for $2 \mathrm{cu}$. ft/hr flow rate and pressure $+1-2.0^{\prime \prime}$ W.C. (of atmospheric pressure), by using the inline flowmeter $(F I)$ indication and the reading from the Rosemount pressure indicating transmitter(PIT 1).

7.18 Purge the input gas line to atmosphere, to the Whittaker cell

\begin{tabular}{|c|c|c|}
\hline DOCUMENT NO & AEVISLON & PAGENO 1. \\
\hline HNF-SD-WM-TC-072 & 0 & 12 of 203 \\
\hline
\end{tabular}


HNF-SD-WH-TRP-274, Rev. 0

CHANGE NUMBER \#3 TO HNF-SD-WM-TC-072

Filo:whitchg1.pro

CHANGES TO $30 \%, 60 \%, 90 \%$ TEST

NOTE: This change allows the gas header supply line, to the cell, to be charged with the specific concentration of calibration gas $(30 \%, 60 \%$, $90 \%)$ before allowing the gas to enter the cell. In this manner the transit time of the gas, from the gas divider to the input of the cell, is minimized.

\section{$30 \%$ TEST}

After Step 7.19: Go to Step 7.29 only for 2 minutes

Step 7.30

Step 7.21: Purge for 2 minutes

Step 7.19: Reset and start stopwatch

Step 7:20

Step 7.22: Take data

\section{$60 \%$ TEST}

After

Step 7.22: Go to to Step 7.27 ( $0 \%$ calibration gas)

Step 7.29: Purge for 2 minutes

Step $7: 30$

Step 7.23: Purge for 2 minutes

Step 7.19: Reset and start stopwatch

Step 7.20

Step 7:22: Take data

90\% TEST

After

Step 7.22: Go to to Step 7.27 (0\% calibration gas)

Step 7.29: Purge for 2 minutes

Step $7: 30$

Step 7.25: Purge for 2 minutes

Step 7.19: Reset and start stopwatch

Step 7.20

Step 7:22: Take data 
HNF-SA-WM-TRP-2T4, Rev 0

This page intentionally Blank

49-1 


\section{TEST PROCEDURE FOR MEASUREMENT OF PERFORMANCE VS TEMPERATURE OF WHITTAKER CELL}

under test, for approximately 2 minutes(from Step 7.17).

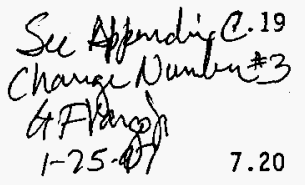

After 2 minutes of purge energize the solenoid valve $(V 6, V 7, V 8, V 9, V 10)$, to the Whittaker under test, by actuation of the respective solenoid control $\operatorname{switch}(S 1, S 2, S 3, S 4, S 5)$ to the "WEC" position.

.20 Verify that the 3 way solenoid valve(V6, V7, V8, V9, V10), to the Whittaker cell under test, is energized, and gas is flowing through the cell, by closing, and then re-opening, the respective manual vent isolation valve(V11,V12,V13,V14,V15) for the whittaker under test. There should be no interruption to gas flowing on flow meter(F1).

NOTE: The 3 way solenoid may not actuate correctly at the extreme test temperatures. If the correct flow of gas cannot be verified, for a particular step in the procedure, actuate the switch from "WEC" to "VENT" until proper flow is observed.

7.21 Move selector switch, on gas divider, to $30 \%$ position. Start stop watch.

7.22 At 2 minutes(120s), at 14 minutes and 30 seconds( $870 \mathrm{~s})$, and at 15 minutes $(900 \mathrm{~s})$ record the voltage output from the $\mathrm{HP} / \mathrm{microvoltmeter}$ system in Appendix B. Also, record one value for the gas pressure from PT 1 , the gas flow from $F 1$, the environmental chamber temperature, and the WEC T/C temperature, from the HP, in Appendix B. Reset stop watch.

7.23 Move selector switch, on gas divider, to $60 \%$ position. Start stop watch.

7.24 Repeat Step 7.22

7.25 Move selector switch, on gas divider, to $90 \%$ position. Start stop watch.

7.26 Repeat Step 7.22

7.27 Ensure that the gas divider(G1) is selected to the $0 \%(100 \%$ balance gas) on the selector switch.

7.28 Purge the Whittaker cell under test for 15 minutes.

\begin{tabular}{|c|c|c|}
\hline DOCUMENT NO & REVISION & PAGENO: \\
\hline HNF-SD-WM-TC-072 & 0 & 13 of 203 \\
\hline
\end{tabular}


7.29 After 15 minutes of purge de-energize the solenoid vaive(v6, $V 7$, V8, $V 9, V 10)$, to the Whittaker under test, by actuation of the respective solenoid control switch $(\$ 1, \$ 2, \$ 3, \$ 4, \$ 5)$ to the "VENT" position.

7.30 Verify that the 3 way solenoid valve(V6,V7,V8,V9,V10), to the Whittaker cell under test, is de-energized, and valve is in venting to atmosphere position by closing, and then re-opening, the respective manual vent isolation valve(V11,V12,V13,V14,V15) for the Whittaker under test. When the vlave is closed there should be a momentary loss of flow observed on flow meter(Fl).

7.31 Move selector switch, on gas divider, to $100 \%$ position.

7.32 Purge the input gas line to atmosphere, to the Whittaker cell under test, for approximately 75 minutes.

After 15 minutes of purge energize the solenoid valve (V6,V7, V8, V9, V10), to the Whittaker under test, by actuation of the respective solenoid control switch(S1,S2,S3,S4,S5) to the "WEC" position.

7.34 Verify that the 3 way solenoid valve(V6,V7, V8, V9, V10), to the Whittaker cell under test, is energized, and gas is flowing through the cell, by closing, and then re-opening, the respective manual vent isolation valve(V11,V12,V13,V14,V15) for the Whittaker under test. There should be no interruption to gas flowing on flow meter(F1).

7.35 At every 15 seconds for 2 minutes (15s, 30s, 45s, 60s, 75s, $90 \mathrm{~s}$, $105 \mathrm{~s}, 120 \mathrm{~s})$ and at 14 minutes and 30 seconds(870s) and at 15 minutes $(900 \mathrm{~s})$, record the voltage output from $\mathrm{HP} /$ microvoltmeter system in Appendix $B$. Also, record one value for the gas: pressure from PT 1 , the gas flow from $F 1$, the environmental chamber temperature, and the WEC T/C temperature, from the HP, in Appendix B.

7.36 Ensure that the gas divider(G1) is selected to the $0 \%(100 \%$ balance gas) on the selector switch.

7.37 Repeat Steps 7.28 through 7.36 two(2) more times then go to Step 7.38 .

7.38 After 15 minutes of purge to the Whittaker cell under test, repeat Steps $7.2,7.3$.

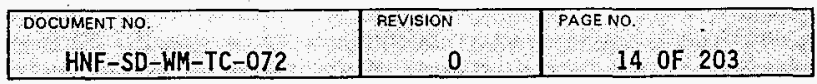

\section{$50-1$}


7.39 If this is the last Whittaker cell to be tested, at the same temperature, go to Step 7.40. If this is not the last Whittaker cel1, to be tested, repeat Steps 7.5 through 7.38 until all Whittaker cells have been tested at the same temperature.

7.40 Decrease the temperature to the environmental chamber by $20^{\circ} \mathrm{F}$. If this temperature IS NOT $-20^{\circ} \mathrm{F}$, and is stable, repeat Steps 7.5 through 7.39. If this temperature Is $-20^{\circ} \mathrm{F}$, and is stable, repeat Steps 7.5 through 7.39 , then go to Step 7.41 .

7.41 Testing as directed by this procedure has been completed. Any discrepancies have been listed on Appendix $C$.

Test Director:

Date:

\begin{tabular}{|c|c|c|}
\hline DOCUMENT NO & REVISTON & PAGENO: \\
\hline $\mathrm{HNF}-\mathrm{SD}-\mathrm{NH}-\mathrm{TC}-072$ & 0 & 15 of 203 \\
\hline
\end{tabular}


TEST PROCEDURE FOR MEASUREMENT OF PERFORMANCE VS TEMPERATURE WHITAKER CELL

8.0 APPENDIX A: MEASUREMENT AND TEST EQUIPMENT RECORD

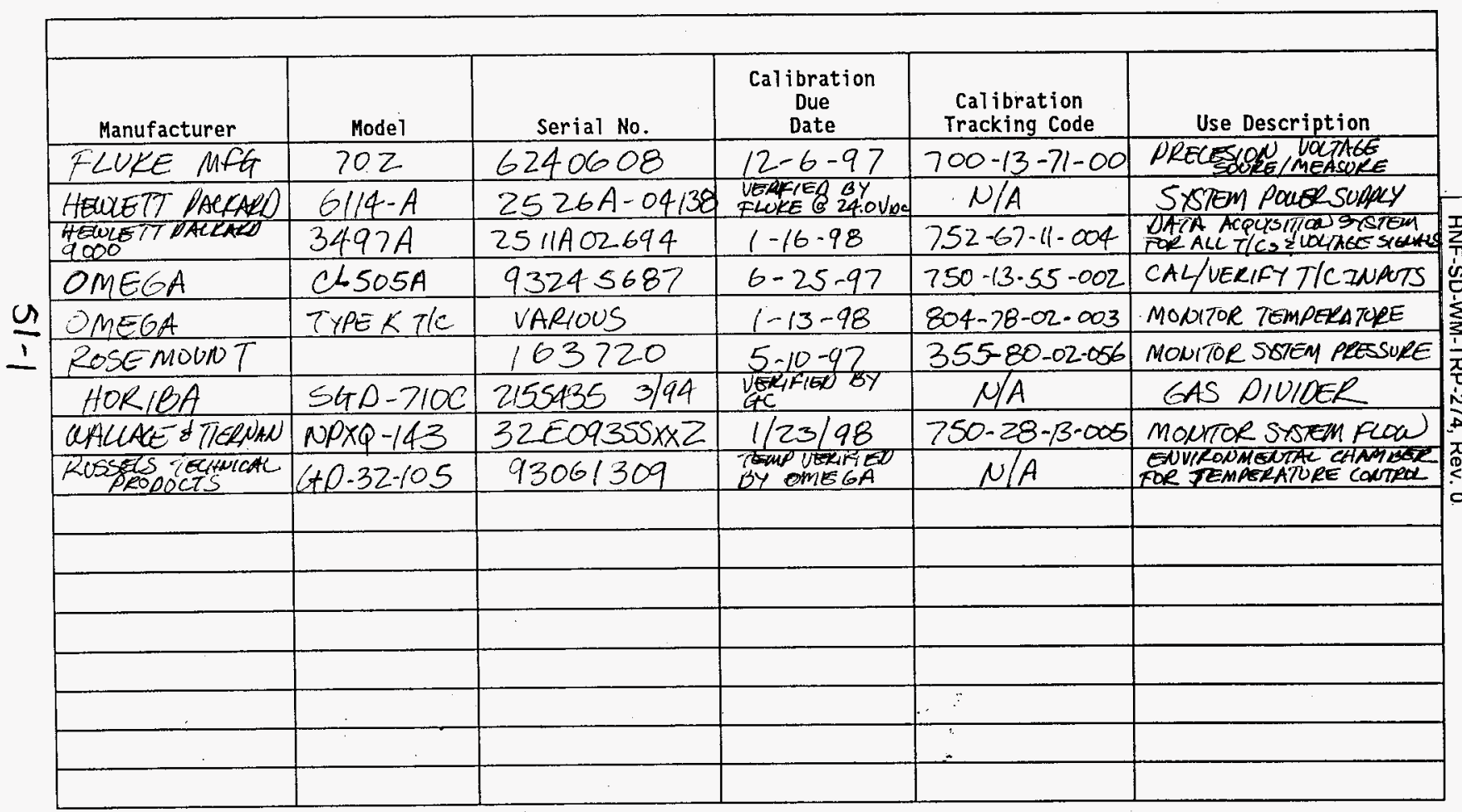

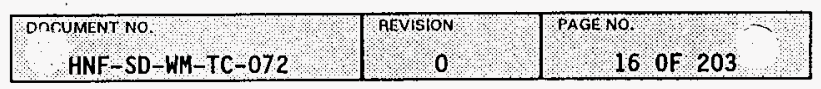




\subsection{APPENDIX B: DATA RECORD}

\section{DATA RECORD TEST NUMBER KEY}

$$
X Y Z
$$

$X$ : Whittaker Identification Number (WIN) I -5

$Y:$ Temperature Identification Number (TIN) $1-8$

$\begin{array}{cccc}1: & -20^{\circ} \mathrm{F} & 5: & +60^{\circ} \mathrm{F} \\ 2: & 0{ }^{\circ} \mathrm{F} & 6: & +80^{\circ} \mathrm{F} \\ 3: & +20^{\circ} \mathrm{F} & 7: & +100^{\circ} \mathrm{F} \\ 4: & +40^{\circ} \mathrm{F} & 8: & +120^{\circ} \mathrm{F}\end{array}$

Z: Test Identification Number (TEIN) $1-4$

1: $30 \%, 60 \%, 90 \%$

2: 1st. $100 \%$

3: 2nd. $100 \%$

4: $\quad 3 r d .100 \%$ 


\subsection{DATA RECORD SHEET 111}

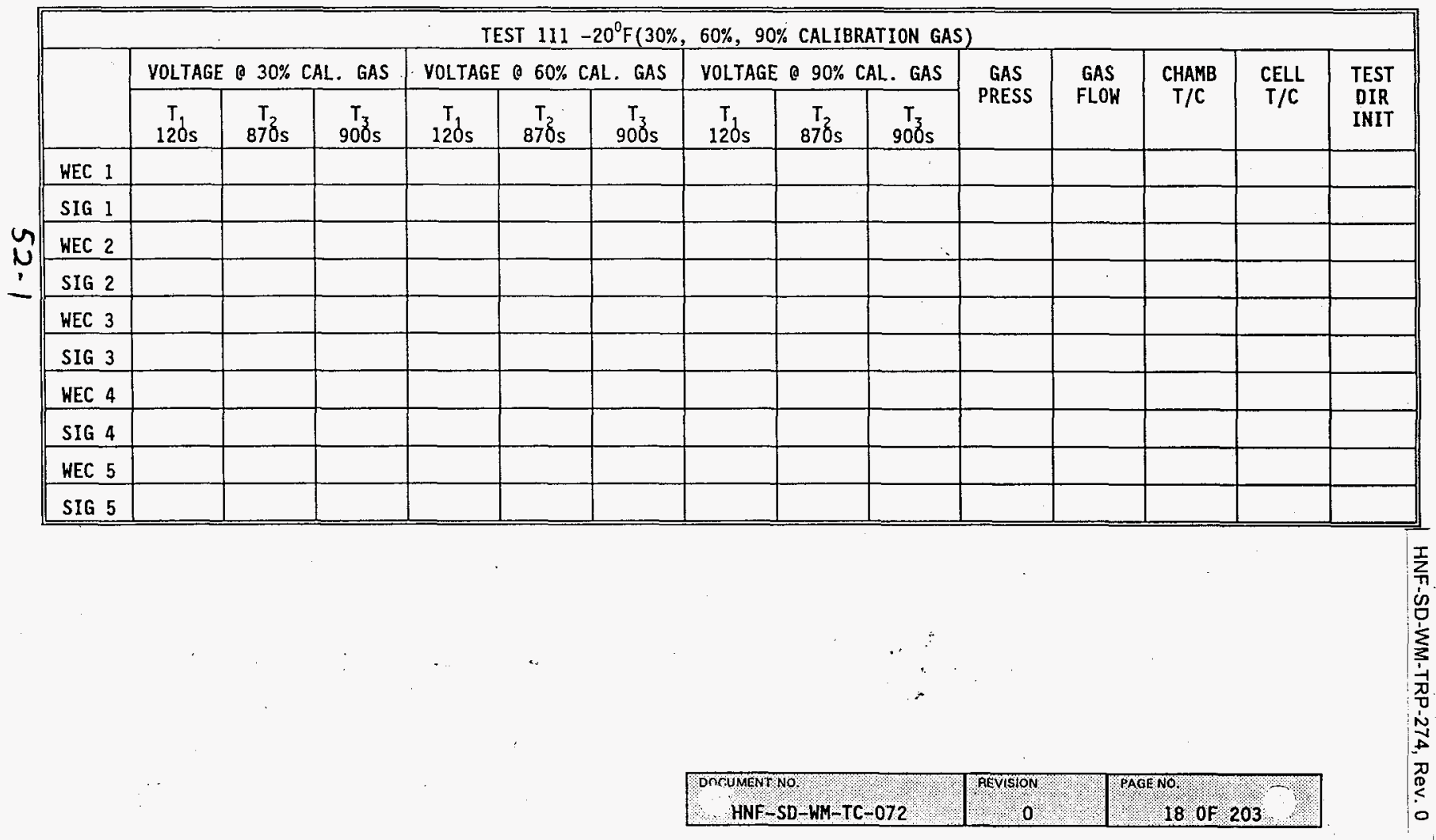




\subsection{DATA RECORD SHEET 112}

\begin{tabular}{|c|c|c|c|c|c|c|c|c|c|c|c|c|c|c|c|}
\hline \multicolumn{16}{|c|}{ TEST $1120-20^{\circ} \mathrm{F}$ (1ST. $100 \%$ CALIBRATION RATE TEST) } \\
\hline & \multicolumn{10}{|c|}{ VOLTAGE } & \multirow{2}{*}{$\begin{array}{c}\text { GAS } \\
\text { PRESS }\end{array}$} & \multirow{2}{*}{$\begin{array}{l}\text { GAS } \\
\text { FLOW }\end{array}$} & \multirow{2}{*}{$\begin{array}{l}\text { CHAM } \\
T / C\end{array}$} & \multirow{2}{*}{$\begin{array}{l}\text { CELL } \\
\text { T/C }\end{array}$} & \multirow{2}{*}{$\begin{array}{l}\text { TEST } \\
\text { DIR. } \\
\text { INIT }\end{array}$} \\
\hline & $\begin{array}{l}T_{1} \\
15 s\end{array}$ & $\begin{array}{l}\mathrm{T}_{2} \\
30 \mathrm{~s}\end{array}$ & $\begin{array}{r}\mathrm{T}_{3} \\
45^{2} \mathrm{~s}\end{array}$ & $\begin{array}{c}T_{4} \\
60 \mathrm{~s}\end{array}$ & $\begin{array}{c}T_{5} \\
75 \mathrm{~s}\end{array}$ & $\begin{array}{l}T_{b}^{6} \\
90 \mathrm{~s}\end{array}$ & $\begin{array}{c}{ }_{10} F_{\mathrm{s}} \\
\end{array}$ & $\begin{array}{c}T_{8} \\
120 \mathrm{~s}\end{array}$ & $\begin{array}{c}\mathrm{T}_{\mathrm{g}} \\
870 \mathrm{~s}\end{array}$ & $\begin{array}{l}\mathrm{T}_{10 \mathrm{o}} \\
900 \mathrm{~s}\end{array}$ & & & & & \\
\hline \multicolumn{16}{|l|}{ WEC 1} \\
\hline \multicolumn{16}{|l|}{ SIG I } \\
\hline \multicolumn{16}{|l|}{ WEC 2} \\
\hline \multicolumn{16}{|l|}{ SIG 2} \\
\hline \multicolumn{16}{|l|}{ WEC 3} \\
\hline \multicolumn{16}{|l|}{ SIG 3} \\
\hline WEC 4 & & & & & & & & & & & & & & & 宽 \\
\hline SIG 4 & & & & & & & & & & & & & & & 으 \\
\hline \multicolumn{16}{|l|}{ WEC 5} \\
\hline SIG 5 & & & & & & & & & & & & & & & \\
\hline
\end{tabular}




\subsection{DATA RECORD SHEET 113}

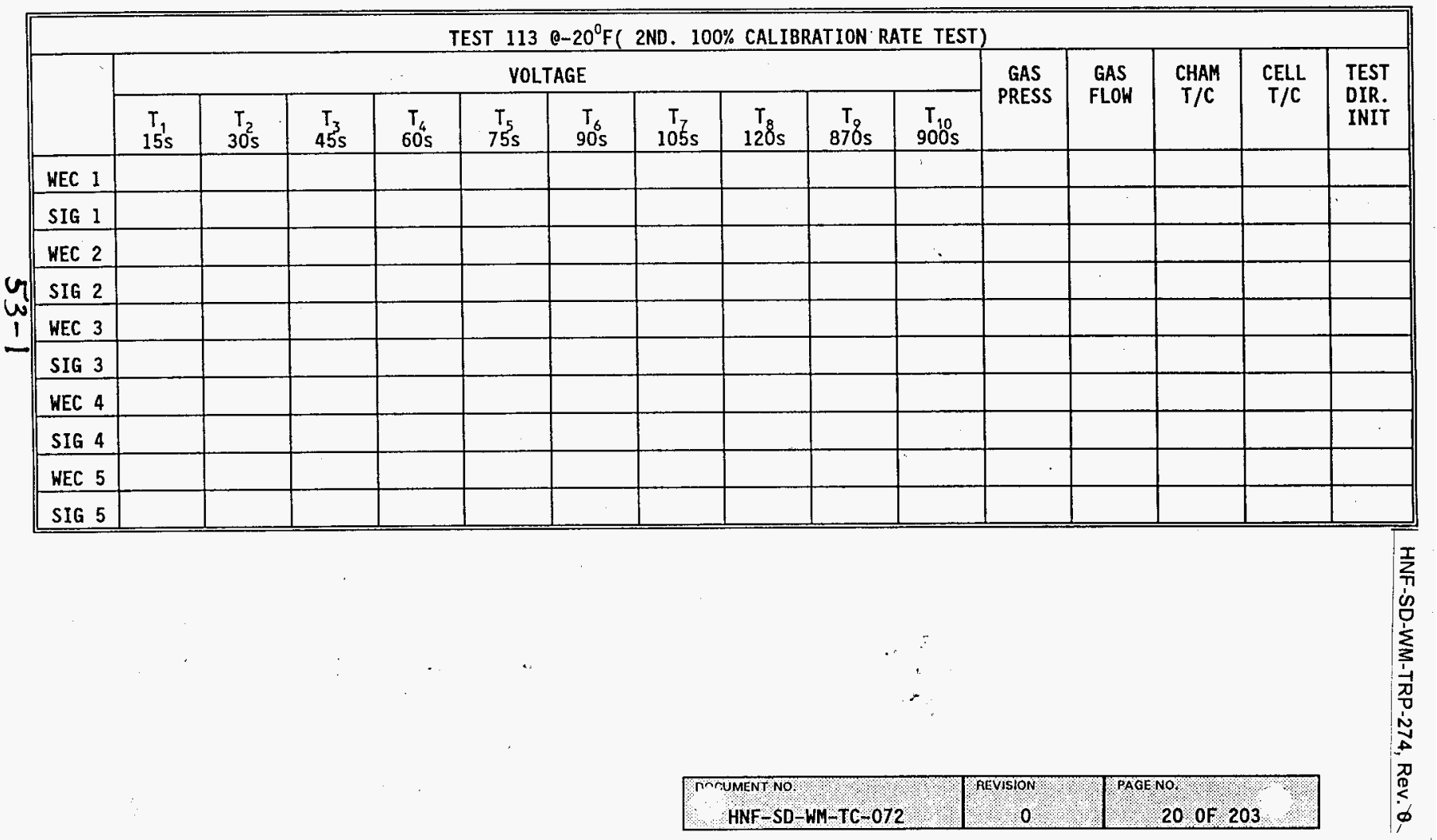




\subsection{DATA RECORD SHEET 114}

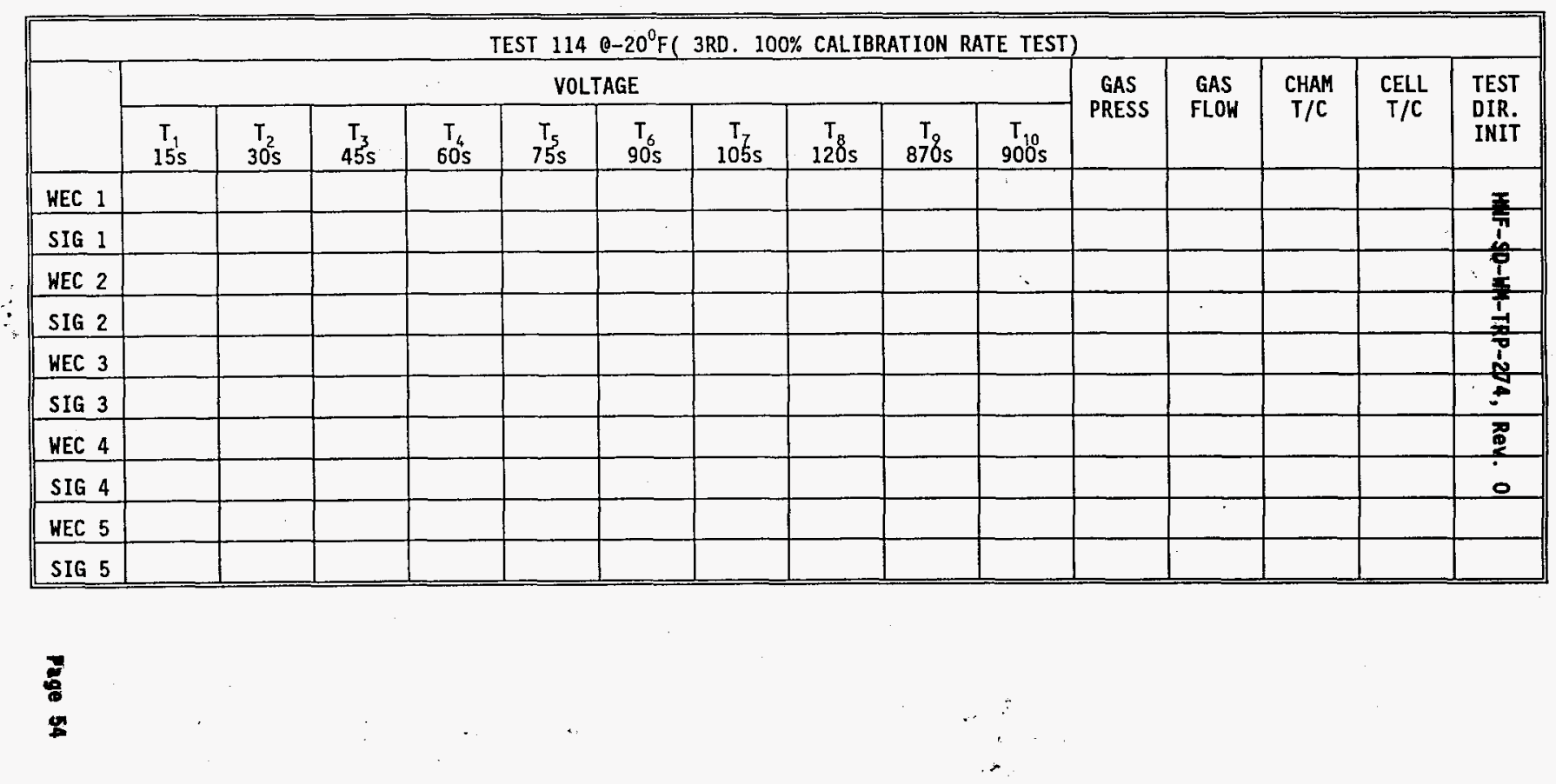

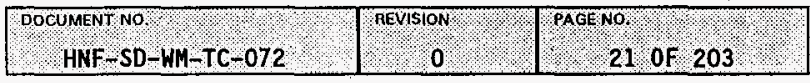


TEST PROCEDURE FOR MEASUREMENT OF PERFORMANCE VS TEMPERATURE WHITTAKER CELL

\subsection{DATA RECORD SHEET 121}

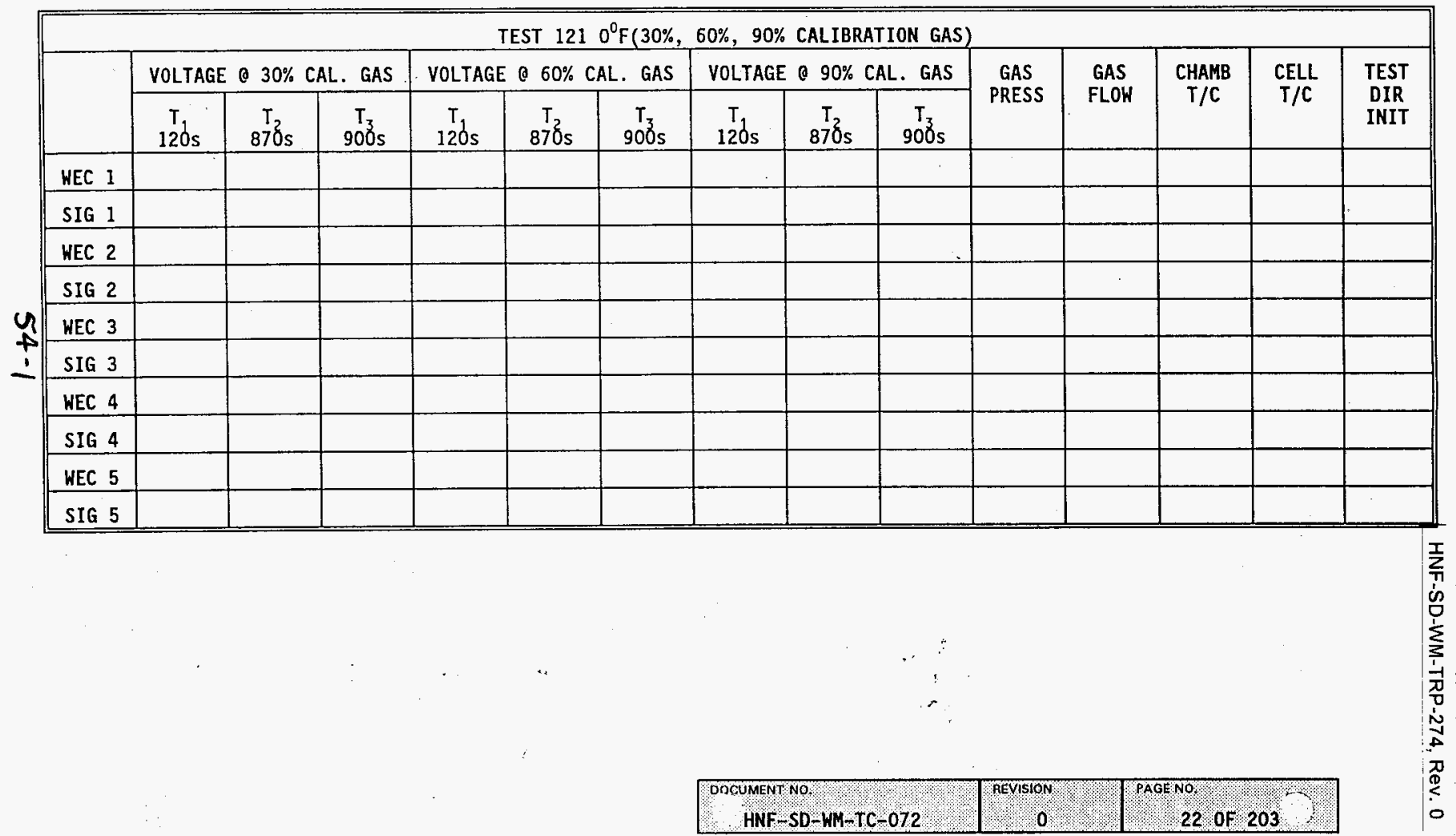




\subsection{DATA RECORD SHEET 122}

\begin{tabular}{|c|c|c|c|c|c|c|c|c|c|c|c|c|c|c|c|}
\hline \multicolumn{16}{|c|}{ TEST $12200^{\circ} \mathrm{F}$ ( 1ST. $100 \%$ CALIBRATION RATE TEST) } \\
\hline & \multicolumn{10}{|c|}{ VOLTAGE } & \multirow{2}{*}{$\begin{array}{l}\text { GAS } \\
\text { PRESS }\end{array}$} & \multirow{2}{*}{$\begin{array}{l}\text { GAS } \\
\text { FLOH }\end{array}$} & \multirow{2}{*}{$\begin{array}{l}\text { CHAM } \\
\text { T/C }\end{array}$} & \multirow{2}{*}{$\begin{array}{l}\text { CELL } \\
T / C\end{array}$} & \multirow{2}{*}{$\begin{array}{l}\text { TEST } \\
\text { DIR. } \\
\text { INIT }\end{array}$} \\
\hline & $\begin{array}{l}T_{1} \\
15 \mathrm{~s}\end{array}$ & $\begin{array}{r}\mathrm{T}_{2} \\
30 \mathrm{~s}\end{array}$ & $\begin{array}{r}T_{3} \\
455 \mathrm{~s}\end{array}$ & $\begin{array}{l}T_{4} \\
605\end{array}$ & $\begin{array}{c}T_{5} \\
75 \mathrm{~s}\end{array}$ & $\begin{array}{l}\mathrm{T}_{6} \\
90 \mathrm{~s}\end{array}$ & ${ }_{105}^{\mathrm{T}} \mathrm{T}_{\mathrm{s}}$ & $\begin{array}{r}T_{8} \\
120 \mathrm{~s} \\
\end{array}$ & $\begin{array}{r}T_{\sigma_{0}} \\
870 s\end{array}$ & $\begin{array}{r}T_{10} \\
900 \mathrm{~s} \\
\end{array}$ & & & & & \\
\hline \multicolumn{16}{|l|}{ HEC 1} \\
\hline \multicolumn{16}{|l|}{ SIG 1} \\
\hline \multicolumn{16}{|l|}{ WEC 2} \\
\hline \multicolumn{16}{|l|}{ SIG 2} \\
\hline \multicolumn{16}{|l|}{ HEC 3} \\
\hline SIG 3 & & & & & & & & & & & & & & & \pm \\
\hline WEC 4 & & & & & & & & & & & & & & & $\mathbb{Z}$ \\
\hline \multicolumn{16}{|l|}{ SIG 4} \\
\hline \multirow{2}{*}{\multicolumn{16}{|c|}{ HEC 5}} \\
\hline SIG 5 & & & & & & & & & & & & & & & \\
\hline
\end{tabular}

용
요 


\subsection{DATA RECORD SHEET 123}

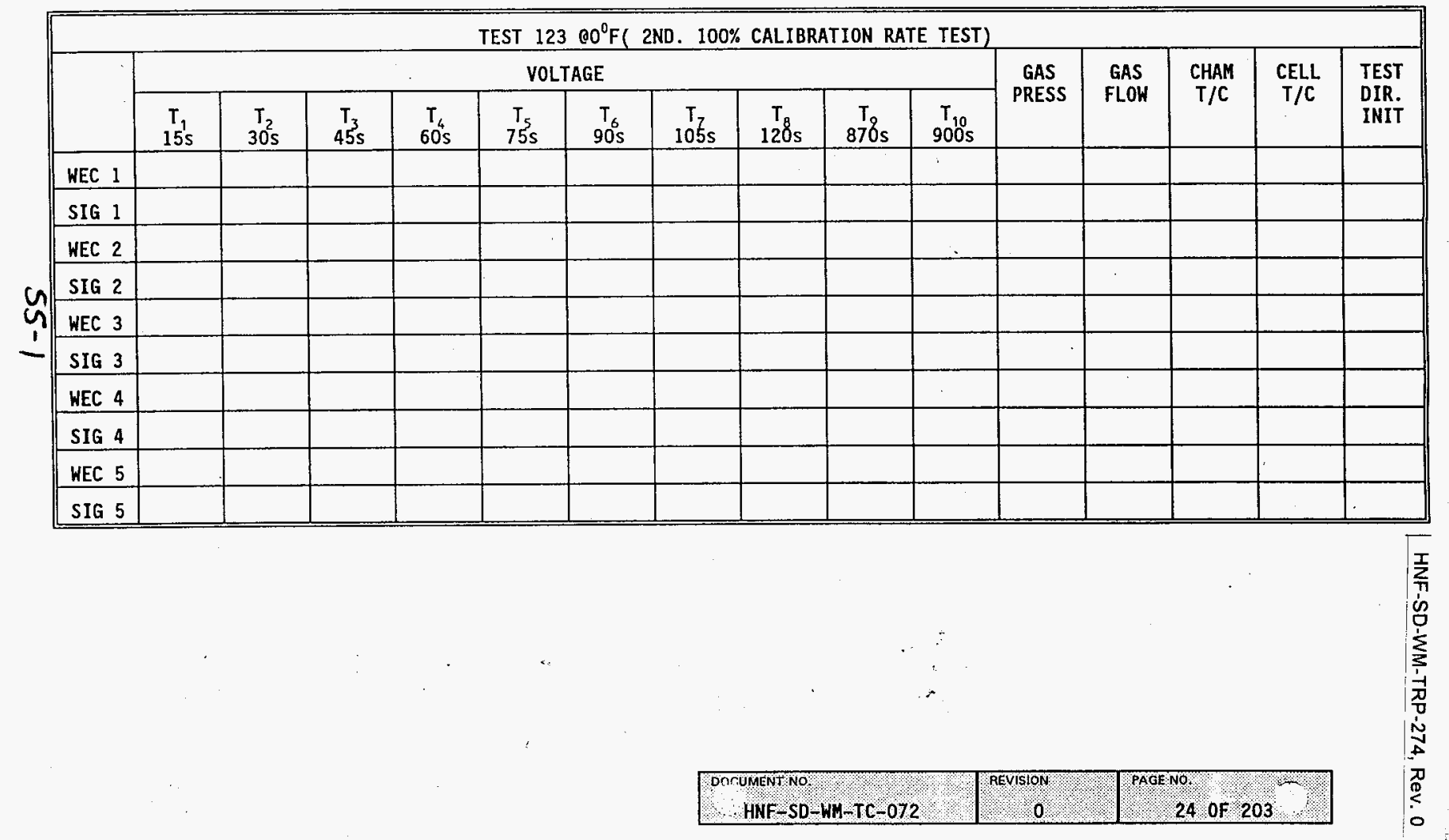




\subsection{DATA RECORD SHEET 124}

\begin{tabular}{|c|c|c|c|c|c|c|c|c|c|c|c|c|c|c|c|}
\hline \multicolumn{16}{|c|}{ TEST $12460^{\circ} \mathrm{F}$ (3RD. 100\% CALIBRATION RATE TEST) } \\
\hline & \multicolumn{10}{|c|}{ VOLTAGE } & \multirow{2}{*}{$\begin{array}{c}\text { GAS } \\
\text { PRESS }\end{array}$} & \multirow{2}{*}{$\begin{array}{l}\text { GAS } \\
\text { FLOW }\end{array}$} & \multirow{2}{*}{$\begin{array}{l}\text { CHAM } \\
\text { T/C }\end{array}$} & \multirow{2}{*}{$\begin{array}{c}\text { CELL } \\
T / C\end{array}$} & \multirow{2}{*}{$\begin{array}{l}\text { TEST } \\
\text { DIR. } \\
\text { INIT }\end{array}$} \\
\hline & $\begin{array}{r}T_{1} \\
15 \mathrm{~s} \\
\end{array}$ & $\begin{array}{c}T_{2} \\
30 \mathrm{~s} \\
\end{array}$ & $\begin{array}{r}T_{3} \\
45 \mathrm{~s} \\
\end{array}$ & $\begin{array}{r}T_{4} \\
60 \mathrm{~s} \\
\end{array}$ & $\begin{array}{c}T_{5} \\
75 \mathrm{~s} \\
\end{array}$ & $\begin{array}{c}T_{6} \\
90 \mathrm{~s}\end{array}$ & $\begin{array}{c}\mathrm{T}_{7} \\
105 \mathrm{~s}\end{array}$ & $\begin{array}{c}\mathrm{T}_{8} \\
120 \mathrm{~s} \\
\end{array}$ & $\begin{array}{c}\mathrm{T} \\
87 \mathrm{~s}_{\mathrm{s}} \\
\end{array}$ & $\begin{array}{r}T_{10} \\
900 \mathrm{~s} \\
\end{array}$ & & & & & \\
\hline \multicolumn{16}{|l|}{ WEC 1} \\
\hline \multicolumn{16}{|l|}{ SIG I } \\
\hline \multicolumn{16}{|l|}{ WEC 2} \\
\hline \multicolumn{16}{|l|}{ SIG 2} \\
\hline \multicolumn{16}{|l|}{ WEC 3} \\
\hline \multicolumn{16}{|l|}{ SIG 3} \\
\hline \multicolumn{16}{|l|}{ WEC 4} \\
\hline SIG 4 & & & & & & & & & & & & & & & 0 \\
\hline \multicolumn{16}{|l|}{ WEC 5} \\
\hline SIG 5 & & & & & & & & & & & & & & & \\
\hline
\end{tabular}

용 


\subsection{DATA RECORD SHEET 131}

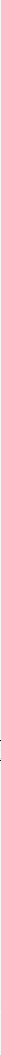


9.10 DATA RECORD SHEET 132

\begin{tabular}{|c|c|c|c|c|c|c|c|c|c|c|c|c|c|c|c|}
\hline \multicolumn{16}{|c|}{ TEST $1320+20^{\circ} \mathrm{F}(1 \mathrm{ST} .100 \%$ CALIBRATION RATE TEST) } \\
\hline & \multicolumn{10}{|c|}{ VOLTAGE } & \multirow{2}{*}{$\begin{array}{c}\text { GAS } \\
\text { PRESS }\end{array}$} & \multirow{2}{*}{$\begin{array}{l}\text { GAS } \\
\text { FLOW }\end{array}$} & \multirow{2}{*}{$\begin{array}{c}\text { CHAN } \\
T / C\end{array}$} & \multirow{2}{*}{$\underset{\mathrm{T} / \mathrm{C}}{\text { CELL }}$} & \multirow{2}{*}{$\begin{array}{l}\text { TEST } \\
\text { DIR. } \\
\text { INIT }\end{array}$} \\
\hline & $\begin{array}{c}T_{1} \\
15 \mathrm{~s}\end{array}$ & $\begin{array}{r}T_{2} \\
30 \mathrm{~s} \\
\end{array}$ & $\begin{array}{r}T_{3} \\
45^{2} \mathrm{~s} \\
\end{array}$ & $\begin{array}{c}\mathrm{T}_{4} \\
60 \mathrm{~s} \\
\end{array}$ & $\begin{array}{r}T_{5} \\
75 s \\
\end{array}$ & $\begin{array}{c}T_{6} \\
90 \mathrm{~S} \\
\end{array}$ & ${ }_{105 \mathrm{~s}}$ & $\begin{array}{c}T_{8} \\
120 \mathrm{~s} \\
\end{array}$ & $\begin{array}{c}T_{8} \\
870 \mathrm{~s}\end{array}$ & $\begin{array}{c}\mathrm{T}_{10} \\
900 \mathrm{~s}\end{array}$ & & & & & \\
\hline \multicolumn{16}{|l|}{ HEC 1} \\
\hline \multicolumn{16}{|l|}{ SIG 1} \\
\hline \multicolumn{16}{|l|}{ WEC 2} \\
\hline \multicolumn{16}{|l|}{ SIG 2} \\
\hline \multicolumn{16}{|l|}{ WEC 3} \\
\hline \multicolumn{16}{|l|}{ SIG 3} \\
\hline \multicolumn{16}{|l|}{ WEC 4} \\
\hline SIG 4 & & & & & & & & & & & & & & & 0 \\
\hline \multicolumn{16}{|l|}{ WEC 5} \\
\hline SIG 5 & & & & & & & & & & & & & & & \\
\hline
\end{tabular}

0
0
0 


\subsection{DATA RECORD SHEET 133}

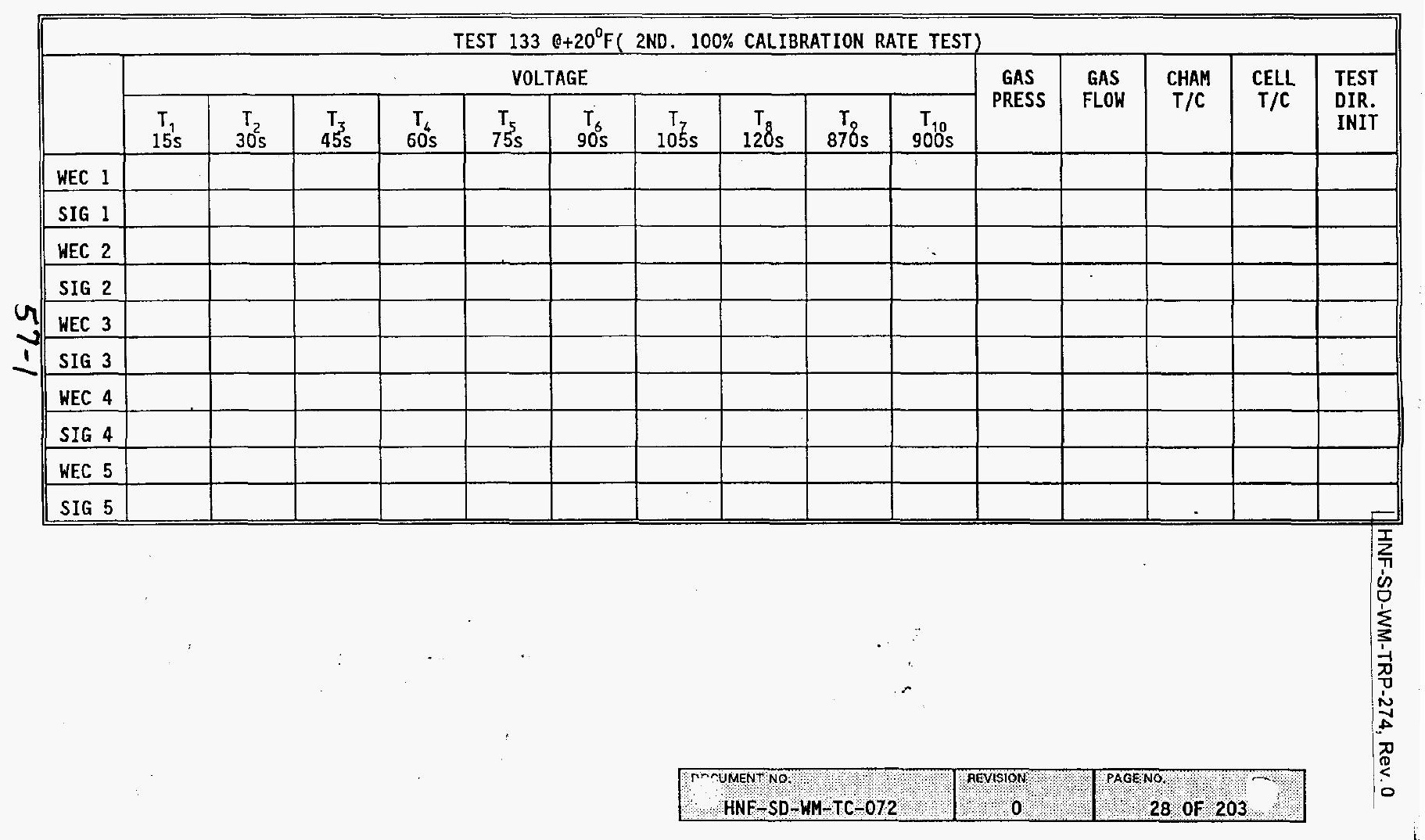


9.12 DATA RECORD SHEET 134

\begin{tabular}{|c|c|c|c|c|c|c|c|c|c|c|c|c|c|c|c|}
\hline \multicolumn{16}{|c|}{ TEST $1340+20^{\circ} \mathrm{F}$ (3RD. $100 \%$ CALIBRATION RATE TEST) } \\
\hline & \multicolumn{10}{|c|}{ VOLTAGE } & \multirow{2}{*}{$\begin{array}{l}\text { GAS } \\
\text { PRESS }\end{array}$} & \multirow{2}{*}{$\begin{array}{l}\text { GAS } \\
\text { FLOW }\end{array}$} & \multirow{2}{*}{$\begin{array}{c}\text { CHAM } \\
\mathrm{T} / \mathrm{C}\end{array}$} & \multirow{2}{*}{$\begin{array}{l}\text { CELL } \\
\mathrm{T} / \mathrm{C}\end{array}$} & \multirow{2}{*}{$\begin{array}{l}\text { TEST } \\
\text { DIR. } \\
\text { INIT }\end{array}$} \\
\hline & $\begin{array}{c}\mathrm{T}_{1} \\
15 \mathrm{~s}\end{array}$ & $\begin{array}{r}\mathrm{T}_{2} \\
30 \mathrm{~s} \\
\end{array}$ & $\begin{array}{r}\mathrm{T}_{3} \\
45 \mathrm{~s} \\
\end{array}$ & $\begin{array}{r}T_{4} \\
60 \mathrm{~s} \\
\end{array}$ & $\begin{array}{l}r_{5} \\
75 \mathrm{~s}\end{array}$ & $\begin{array}{c}T_{6} \\
90 \mathrm{~s}\end{array}$ & $\begin{array}{c}\mathrm{T}_{\mathrm{T}} \\
105 \mathrm{~s}\end{array}$ & $\begin{array}{c}\mathrm{T}_{\mathrm{g}} \\
120 \mathrm{~s}\end{array}$ & $\begin{array}{c}\mathrm{T} / \mathrm{O} \\
870 \mathrm{~s}\end{array}$ & $\begin{array}{r}\mathrm{T}_{10} \\
900 \mathrm{~s} \\
\end{array}$ & & & & & \\
\hline \multicolumn{16}{|l|}{ WEC 1} \\
\hline \multicolumn{16}{|l|}{ SIG 1} \\
\hline \multicolumn{16}{|l|}{ WEC 2} \\
\hline \multicolumn{16}{|l|}{ SIG 2} \\
\hline \multicolumn{16}{|l|}{ WEC 3} \\
\hline \multicolumn{16}{|l|}{ SIG 3} \\
\hline WEC 4 & & & & & & & & & & & & & & & 疍 \\
\hline SIG 4 & & & & & & & & & & & & & & & 은 \\
\hline \multicolumn{16}{|l|}{ WEC 5} \\
\hline SIG 5 & & & & & & & & & & & & & & & \\
\hline
\end{tabular}

8 
9.13 DATA RECORD SHEET 141

SUREMENT OF PERFORMANCE VS TEMPERATURE

WHITAKER CELL

TEST PROCEDURE FOR MEAS UR

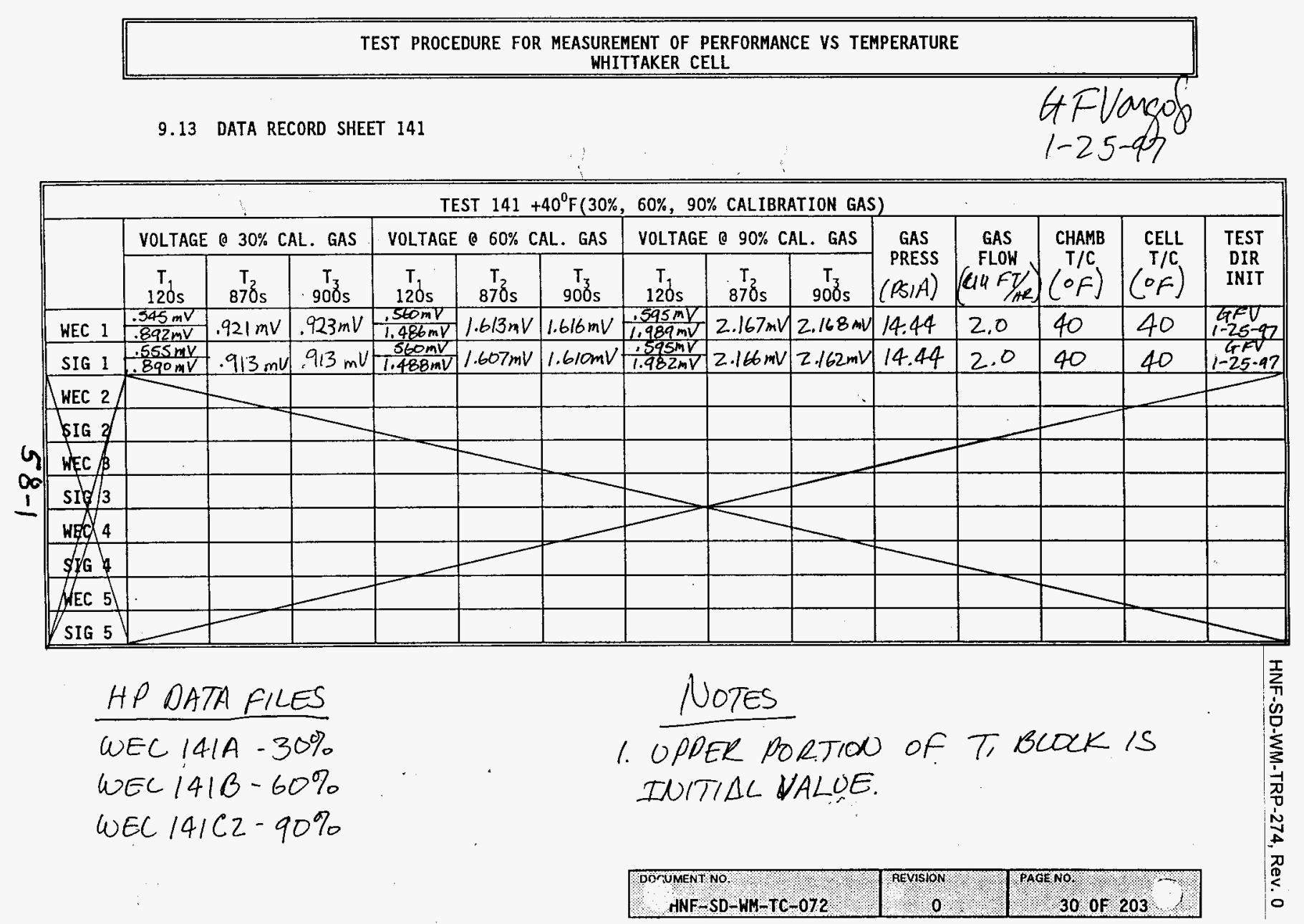


TEST PROCEDURE FOR MEASUREMENT OF PERFORMANCE VS TEMPERATURE WHITAKER CELL

9.14 DATA RECORD SHEET 142

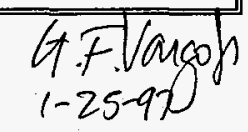

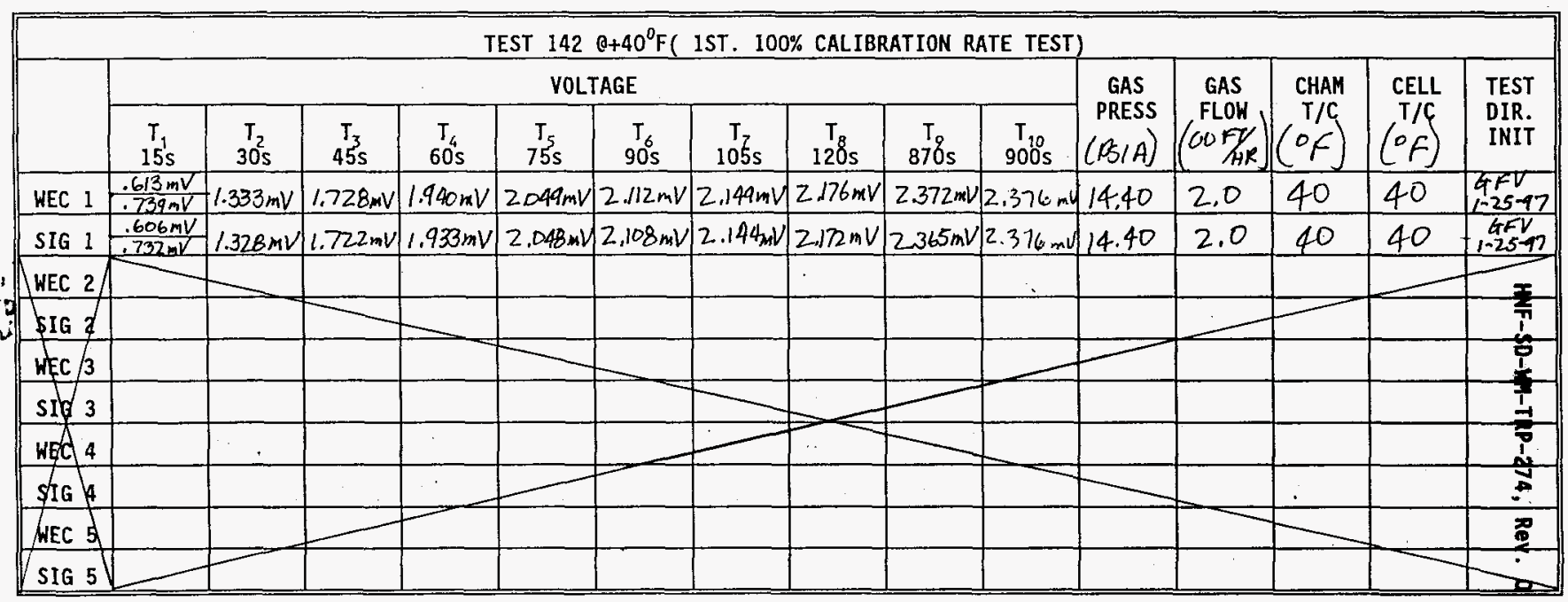

$=\frac{\text { HP DATA FILE }}{\text { DEC } 1422-15 T 100 \%}$

NOTES

1. UPPER PORTION OF TI BCOCK IS initial value.

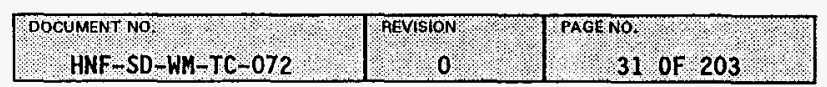




\begin{tabular}{|c|c|c|c|c|c|c|c|c|c|c|c|c|c|c|c|}
\hline \multicolumn{16}{|c|}{ TEST $1430+40^{\circ} \mathrm{F}$ ( $2 \mathrm{ND} .100 \%$ CALIBRATION RATE TEST) } \\
\hline & \multicolumn{10}{|c|}{ VOLTAGE } & \multirow{2}{*}{$\begin{array}{c}\text { GAS } \\
\text { PRESS } \\
(A S, A) \\
\end{array}$} & \multirow{2}{*}{$\begin{array}{c}\text { GAS } \\
\text { FLOW } \\
(C \cup F T / R R)\end{array}$} & \multirow{2}{*}{$\begin{array}{l}\text { CHAM } \\
\text { T/C } \\
(\circ \mathrm{F})\end{array}$} & \multirow{2}{*}{$\begin{array}{l}\text { CELL } \\
T / C \\
\left({ }^{\circ} f\right)\end{array}$} & \multirow{2}{*}{$\begin{array}{l}\text { TEST } \\
\text { DIR. } \\
\text { INIT }\end{array}$} \\
\hline & $\begin{array}{c}\mathrm{T}_{1} \\
15 \mathrm{~s} \\
\end{array}$ & $\begin{array}{r}\mathrm{T}_{2} \\
30 \mathrm{~s} \\
\end{array}$ & $\begin{array}{r}T_{3} \\
45 \\
\end{array}$ & $\begin{array}{r}T_{4} \\
60 \mathrm{~s} \\
\end{array}$ & $\begin{array}{r}T_{5} \\
75 \mathrm{~s} \\
\end{array}$ & $\begin{array}{c}T_{6} \\
90 s \\
\end{array}$ & $\begin{array}{c}T_{Z} \\
105 \mathrm{~s} \\
\end{array}$ & $\begin{array}{r}T_{8} \\
120 \mathrm{~s} \\
\end{array}$ & $\begin{array}{c}T_{9} \\
87 \delta_{s}\end{array}$ & $\begin{array}{l}\mathrm{T}_{10} \\
900 \mathrm{~s}\end{array}$ & & & & & \\
\hline WEC I & $\begin{array}{ll}.638 \mathrm{mV} \\
.733 \mathrm{mV} \\
\end{array}$ & $1.343 \mathrm{mV}$ & $1.761 \mathrm{mV}$ & $1.970 \mathrm{mV}$ & $2.079 \mathrm{mV}$ & $2.144 \mathrm{mV}$ & $2.180 \mathrm{ml}$ & $2.208 \mathrm{mV}$ & $2.404 \mathrm{mV}$ & $2400 \mathrm{mV}$ & 14.41 & 2.0 & 40 & 40 & $\begin{array}{l}6 F V \\
1-25-10\end{array}$ \\
\hline SIG 1 & $\begin{array}{r}.663 \mathrm{mV} \\
.638 \mathrm{mV} \\
.767 \mathrm{mV} \\
\end{array}$ & $1.343 \mathrm{WV}$ & $1.76 \mathrm{mV}$ & $1.965 \mathrm{mV}$ & $2.07 \mathrm{mV}$ & $2,138 \mathrm{mV}$ & $2.175 \mathrm{mV}$ & $2.207 \mathrm{mV}$ & $2,398 \mathrm{mV}$ & $2.406 \mathrm{mV}$ & 14.41 & 2.0 & 40 & 40 & $\begin{array}{c}4+25 \\
1-25-97\end{array}$ \\
\hline WEC 2 & & 3 & & & & & & & & & & & & & $I_{I}$ \\
\hline SIG 2 & & & & & & & & & & & & 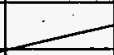 & & & i \\
\hline WEC 3 & & & & & & & & & & & & & & & 空 \\
\hline $\sin 3$ & & & & & & & & & & & & & & & $\sum_{3}^{3}$ \\
\hline WEC 4 & & & & & & & & & + & & & & & & 富 \\
\hline 51614 & & & & & & & & & & & 3 & & & & $\stackrel{\sim}{\sim}$ \\
\hline MEC 5 & & & 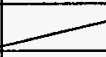 & & & & & & & & & & & & 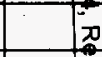 \\
\hline SIG 5 & & & & & & & & & & & & & & & \\
\hline
\end{tabular}

HP DATA FILE

WEC 143-200 100\%.

\section{NOTES}

1. OPPER PORTION OF TI BLOCK IS YUTTIAL UALUE 2. PURGE TIME ON CEL $30 \mathrm{~m} 60 \%$ 


$$
\begin{aligned}
& \exists 07 \forall \cap 7 \forall 1 L Q A
\end{aligned}
$$

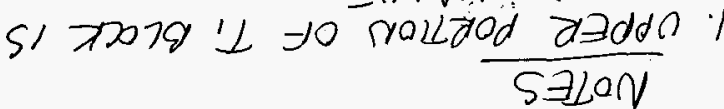

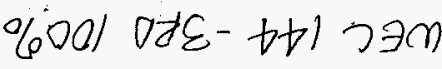

\begin{tabular}{|c|c|c|c|c|c|c|c|c|c|c|c|c|c|c|c|}
\hline$a$ & & & & & & & & & & & & & & & S 9IS \\
\hline वे & & 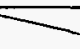 & & & & & & & & & & 工 & & & S J3M \\
\hline 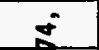 & & & & & & & & & & & & & & & t) 015 \\
\hline & & & & & & & & & & & & & & & 6 ba \\
\hline$I$ & & & & & & & & & & & & & & & $\varepsilon$ AIs \\
\hline & & & & 1 & & & & & & 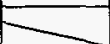 & & & & & $\varepsilon / \partial \exists \mu$ \\
\hline 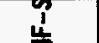 & & 7 & & & & & & & & & & $x^{2}$ & & & F VIS \\
\hline & & & & & & & & & & & & & & & $253 M$ \\
\hline Lb-sc-1 & ob & ot & 0.2 & $|b| t \mid$ & $h m s g t z$ & $4 w 28 b^{2} z$ & $h m \varepsilon s z z$ & $14+52=2$ & 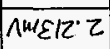 & Ambtr'z & Amsconz & 140281 & 1meot'l & 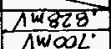 & I 9IS \\
\hline 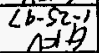 & ot & $a t$ & 0.2 & $10 * t 1$ & $\Lambda m a b b^{\prime} z$ & $M^{m} L 8 b^{\prime} z$ & $1 w+8 z^{\prime} z$ & $14852 \cdot 2$ & $A^{\prime}<\angle Z^{\prime} Z$ & Nusglz & $\Lambda^{m} g \varepsilon \triangle Z$ & $A^{*} \varepsilon z 8 \%$ & $\lambda^{m} 6001$ & $\frac{A^{m} b 28^{\circ}}{A^{m} 10 L^{\circ}}$ & I $33 M$ \\
\hline LINI & (-) & (to) & $\left(\sum_{L \rightarrow H}^{H} m\right)$ & $(t / s d)$ & $\begin{array}{l}5006 \\
0 l_{1}\end{array}$ & $\delta_{1}^{50 / 8}$ & $\begin{array}{l}\text { SOZII } \\
\text { I }\end{array}$ & squor & $\begin{array}{l}506 \\
906 \\
1\end{array}$ & $\begin{array}{l}\text { SgL } \\
\xi_{1}\end{array}$ & $\begin{array}{l}\text { s09 } \\
1\end{array}$ & $\begin{array}{l}s_{5} \text { t } \\
\varepsilon_{1}\end{array}$ & $\begin{array}{l}50 \varepsilon \\
2_{1}\end{array}$ & $\begin{array}{c}\text { sG I } \\
1_{1}\end{array}$ & \\
\hline ISJI & כברา & WYHJ & SHg & SWY & \multicolumn{10}{|c|}{$\exists 9 \forall 170 \Lambda$} & \\
\hline
\end{tabular}

$$
\begin{aligned}
& \text { छान } \forall \forall \forall O d H
\end{aligned}
$$

$$
\text { yourontin }
$$




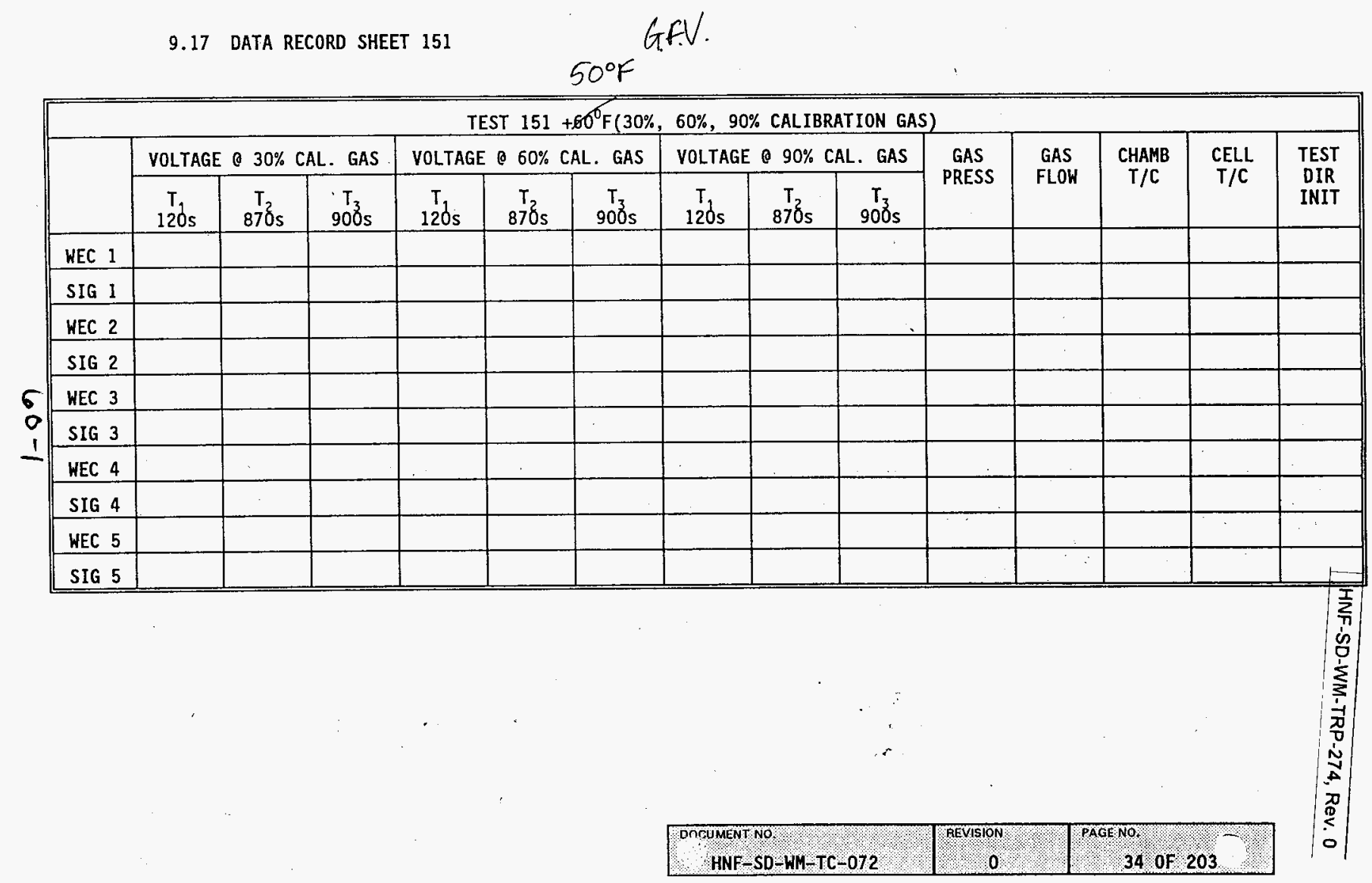


TEST PROCEDURE FOR MEASUREMENT OF PERFORMANCE VS TEMPERATURE WHITTAKER CELL

9.18 DATA RECORD SHEET 152

$60^{\circ} \mathrm{F}$ G.F.V.

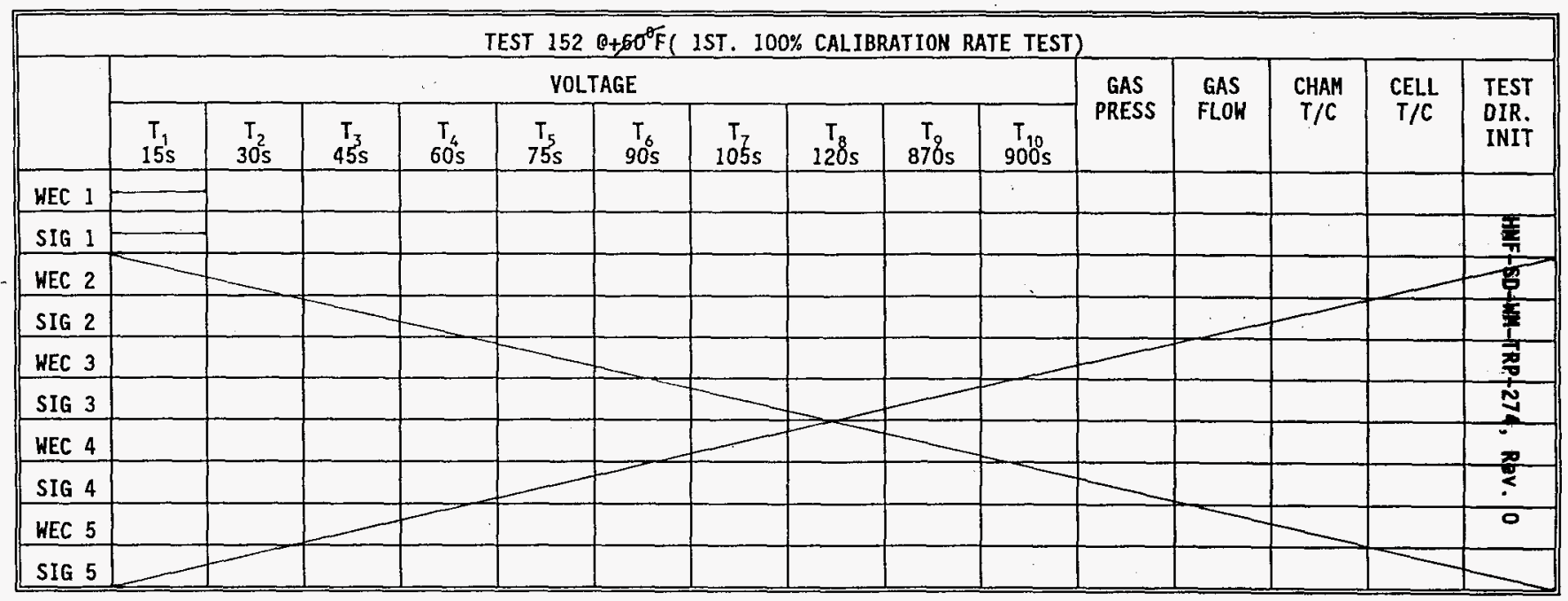

HP DATA FILE

WE C ।
Notes

1. UPPER PORTION OF TI SLOCK is iniTial value.

$$
\text { DOCUMENT }
$$




\subsection{DATA RECORD SHEET 153}

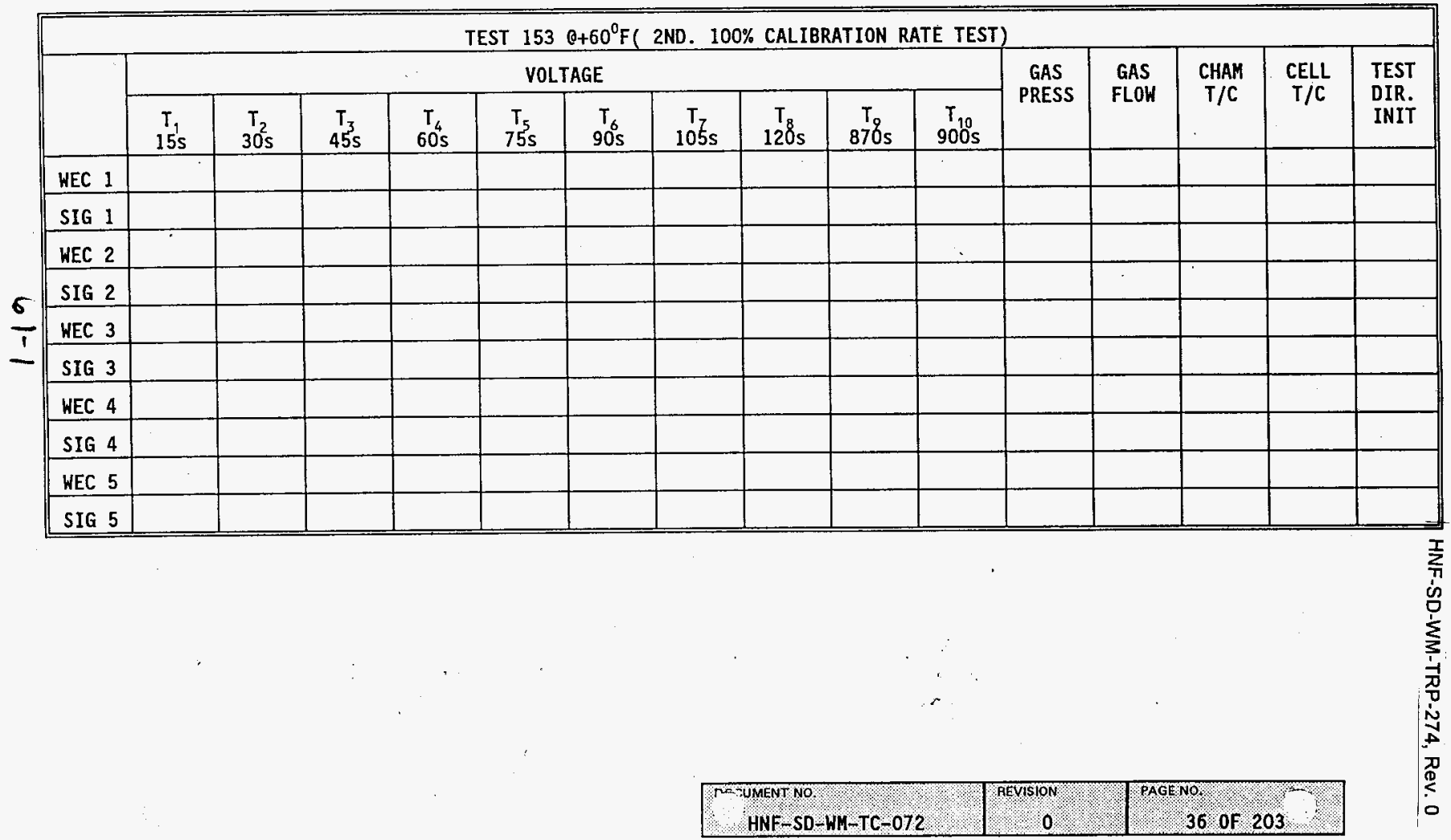




\subsection{DATA RECORD SHEET 154}

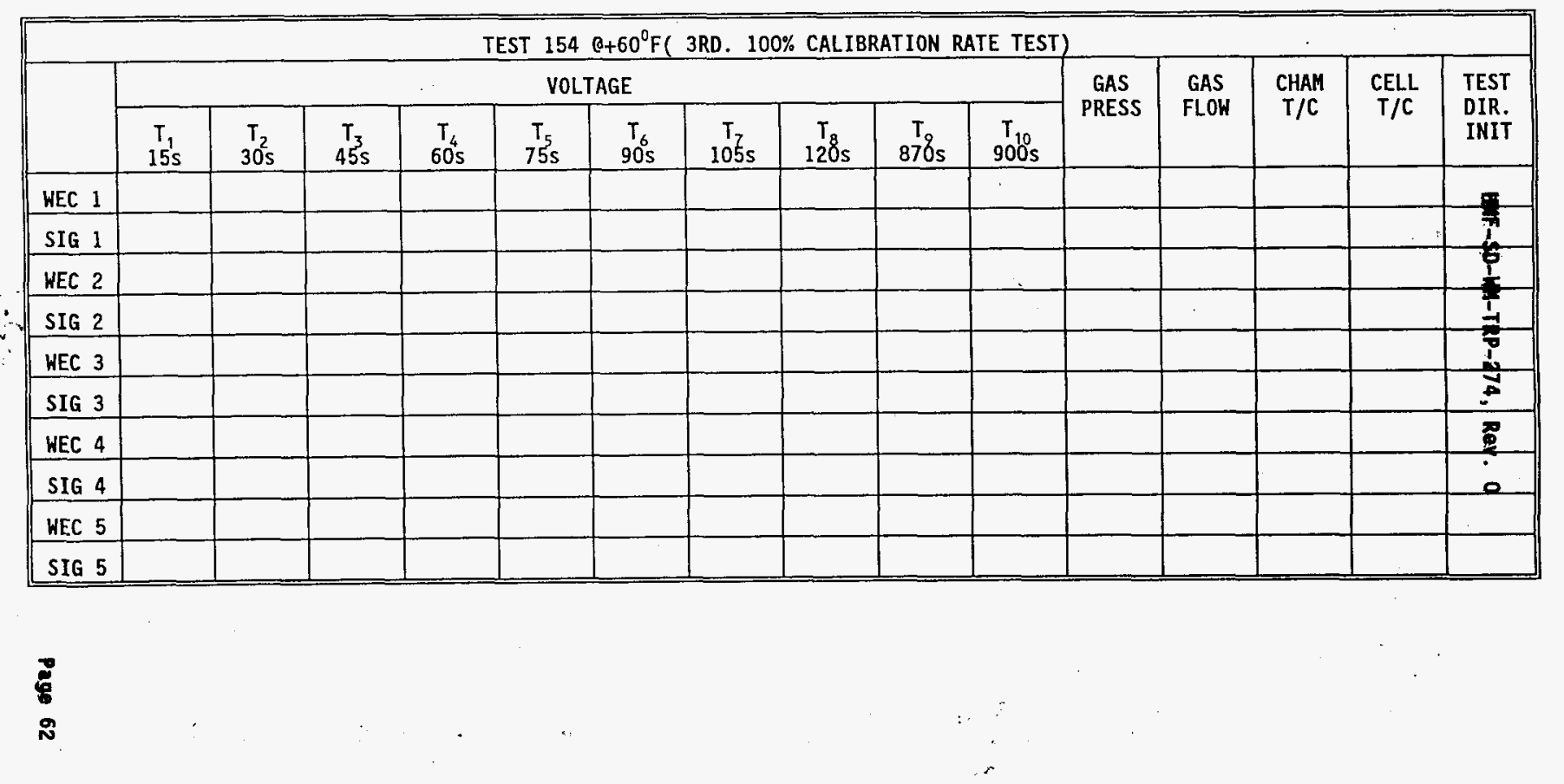

\begin{tabular}{|c|c|c|}
\hline $\begin{array}{l}\text { DOCUMENTNO } \\
\text { HNF - SD - WM-TC-072 }\end{array}$ & REVISION & PAGENOF 37 OF 203 \\
\hline
\end{tabular}




\subsection{DATA RECORD SHEET 161}

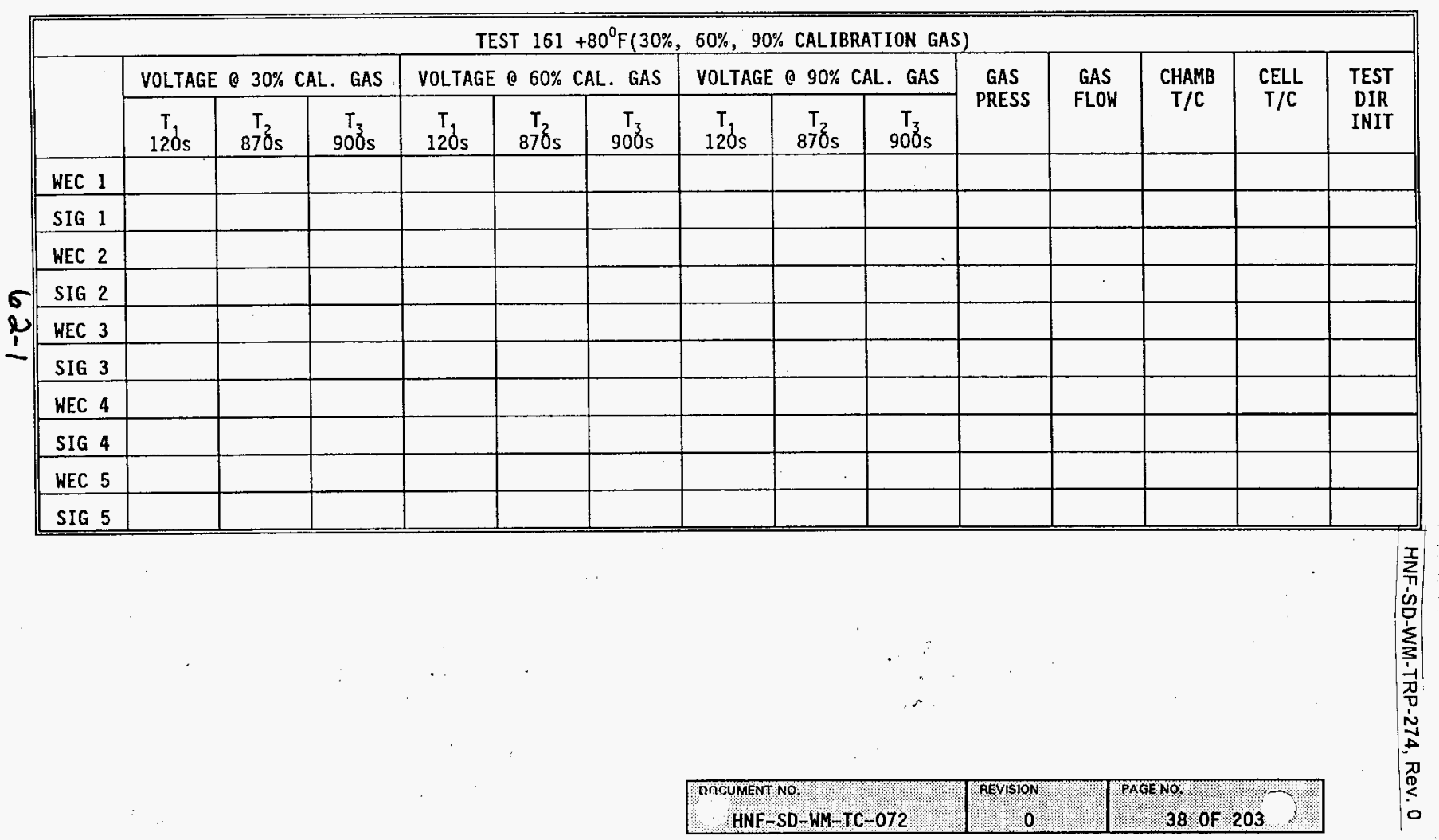




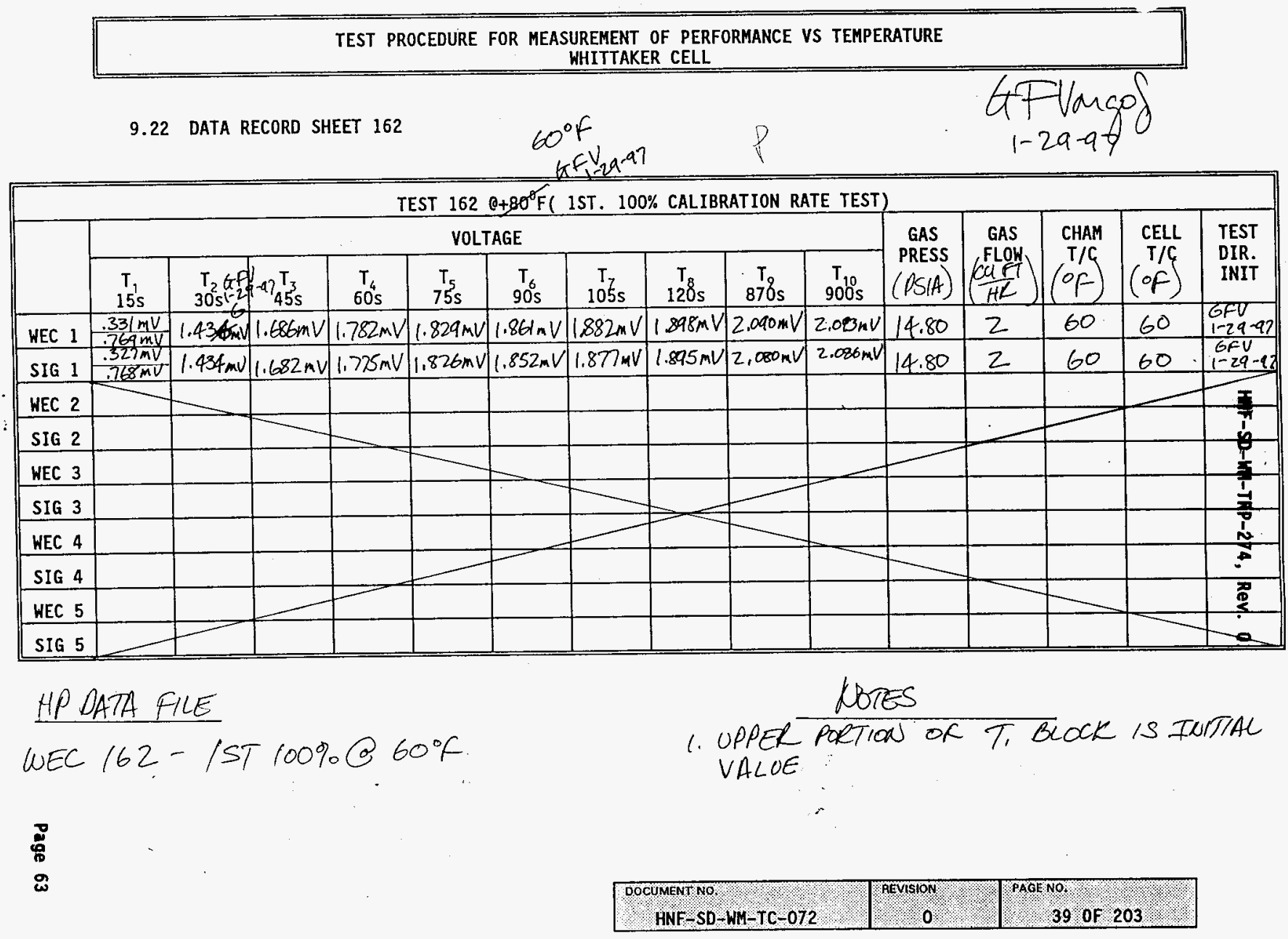




\subsection{DATA RECORD SHEET 163}

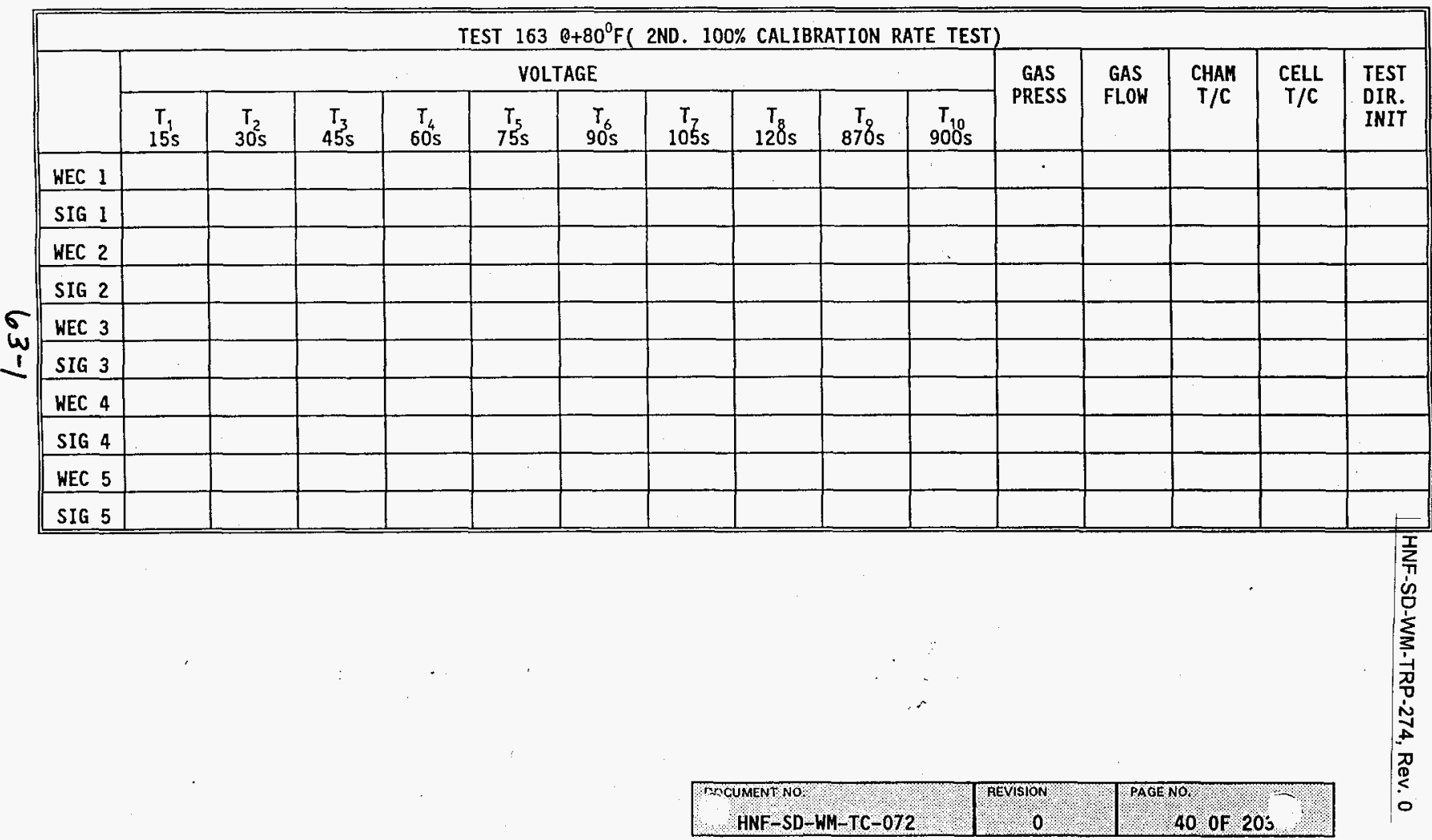




\subsection{DATA RECORD SHEET 164}

\begin{tabular}{|c|c|c|c|c|c|c|c|c|c|c|c|c|c|c|c|}
\hline \multicolumn{16}{|c|}{ TEST $1640+80^{\circ} \mathrm{F}$ (3RD. $100 \%$ CALIBRATION RATE TEST) } \\
\hline & \multicolumn{10}{|c|}{ VOLTAGE } & \multirow{2}{*}{$\begin{array}{c}\text { GAS } \\
\text { PRESS }\end{array}$} & \multirow{2}{*}{$\begin{array}{l}\text { GAS } \\
\text { FLOW }\end{array}$} & \multirow{2}{*}{$\begin{array}{l}\text { CHAM } \\
\mathrm{T} / \mathrm{C}\end{array}$} & \multirow{2}{*}{$\frac{\text { CELL }}{T / C}$} & \multirow{2}{*}{$\begin{array}{l}\text { TEST } \\
\text { DIR. } \\
\text { INIT }\end{array}$} \\
\hline & $\begin{array}{r}T_{1} \\
15 \mathrm{~s} \\
\end{array}$ & $\begin{array}{r}\mathrm{T}_{2} \\
30 \mathrm{~s} \\
\end{array}$ & $\begin{array}{r}T_{3} \\
45 \mathrm{~s} \\
\end{array}$ & $\begin{array}{r}T_{4} \\
60 \mathrm{~s} \\
\end{array}$ & $\begin{array}{r}T_{5} \\
75 \mathrm{~s} \\
\end{array}$ & $\begin{array}{r}T_{6} \\
90 \mathrm{~s} \\
\end{array}$ & $\begin{array}{c}\mathrm{T} \\
105 \mathrm{~s}\end{array}$ & $\begin{array}{c}\mathrm{T}_{8} \\
120 \mathrm{~s} \\
\end{array}$ & $\begin{array}{c}\mathrm{T} / \mathrm{g} \\
870 \mathrm{~s}\end{array}$ & $\begin{array}{c}\mathrm{T}_{10} \\
900 \mathrm{~s} \\
\end{array}$ & & & & & \\
\hline \multicolumn{16}{|l|}{ WEC 1} \\
\hline \multicolumn{16}{|l|}{ SIG 1} \\
\hline \multicolumn{16}{|l|}{ WEC 2} \\
\hline \multicolumn{16}{|l|}{ SIG 2} \\
\hline \multicolumn{16}{|l|}{ WEC 3} \\
\hline \multicolumn{16}{|l|}{ SIG 3} \\
\hline \multicolumn{15}{|l|}{ WEC 4} & 刃 \\
\hline \multicolumn{16}{|l|}{ SIG 4} \\
\hline \multicolumn{16}{|l|}{ WEC 5} \\
\hline SIG 5 & & & & & & & & & & & & & & & \\
\hline
\end{tabular}

8
8
8

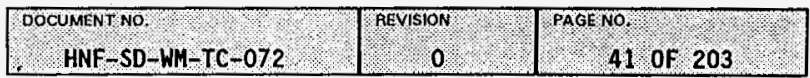




\subsection{DATA RECORD SHEET 171}

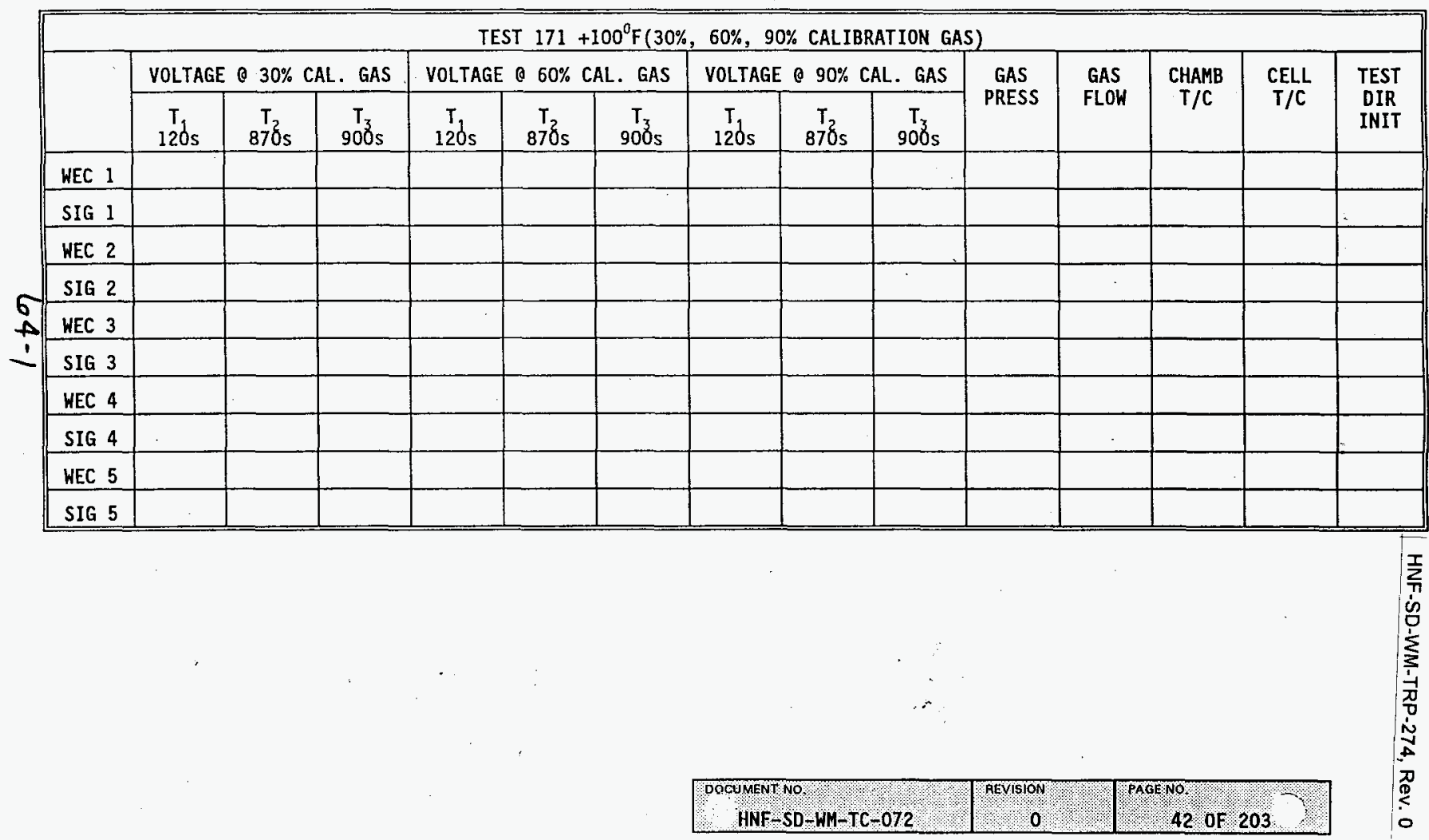


TEST PROCEDURE FOR MEASUREMENT OF PERFORMANCE VS TEMPERATURE

WHITAKER CELL

9.26 DATA RECORD SHEET 172

$$
10^{\circ} \times\left(4+\frac{1}{1-29-97}\right.
$$

GFVargof $1-29-97$

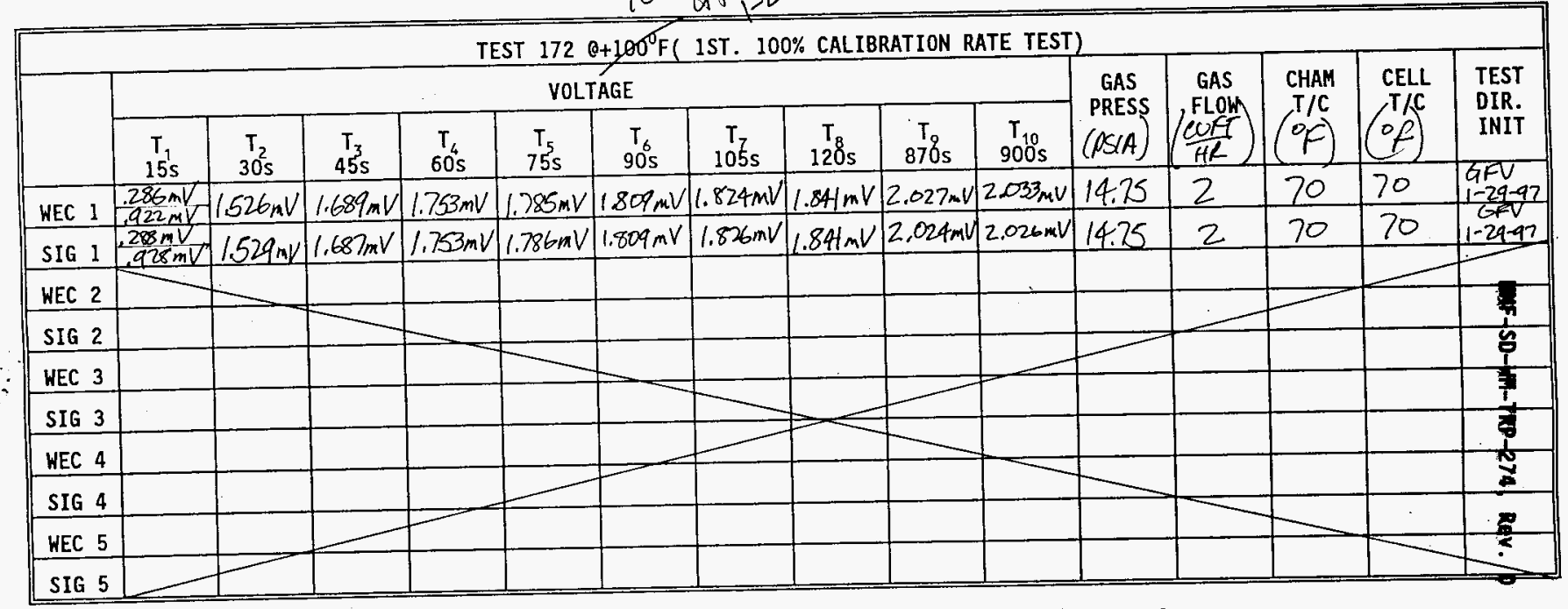

HP DATA EOE

WED 172 - 1 st $100 \% 870 \%$

1. UPPER PORTIOW OF T, BLOCK is IUTRILL UALUE. 8
8
8

DOCUMENT NO.


9.27 DATA RECORD SHEET 173

$$
80^{\circ} \times \mathrm{N}_{-3}-9 \text { ? }
$$

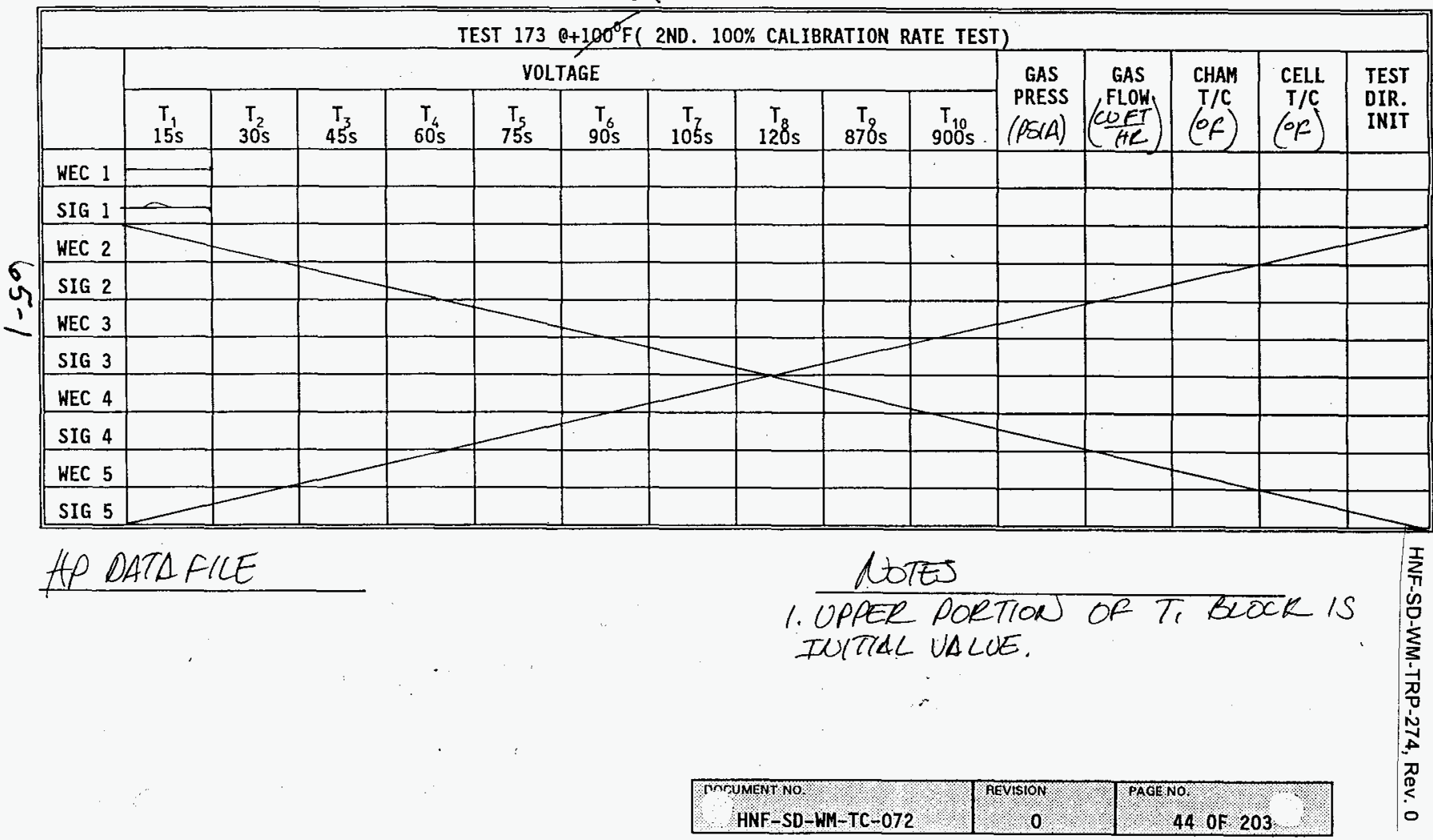




\subsection{DATA RECORD SHEET 174}

\begin{tabular}{|c|c|c|c|c|c|c|c|c|c|c|c|c|c|c|c|}
\hline \multicolumn{16}{|c|}{ TEST $1740+100^{\circ} \mathrm{F}$ (3RD. $100 \%$ CALIBRATION RATE TEST) } \\
\hline & \multicolumn{10}{|c|}{ VOLTAGE } & \multirow{2}{*}{$\begin{array}{l}\text { GAS } \\
\text { PRESS }\end{array}$} & \multirow{2}{*}{$\begin{array}{l}\text { GAS } \\
\text { FLOW }\end{array}$} & \multirow{2}{*}{$\frac{\text { CHAM }}{T / C}$} & \multirow{2}{*}{$\begin{array}{l}\text { CELL } \\
T / C\end{array}$} & \multirow{2}{*}{$\begin{array}{l}\text { TEST } \\
\text { DIR. } \\
\text { INIT }\end{array}$} \\
\hline & $\begin{array}{r}T_{1} \\
15 \mathrm{~s} \\
\end{array}$ & $\begin{array}{r}\mathrm{T}_{2} \\
30 \mathrm{~s} \\
\end{array}$ & $\begin{array}{r}T_{3} \\
45^{3} \mathrm{~s} \\
\end{array}$ & $\begin{array}{r}T_{4} \\
60 \mathrm{~s} \\
\end{array}$ & $\begin{array}{c}T_{5} \\
75 \mathrm{~s}\end{array}$ & $\begin{array}{c}T_{6} \\
905 \\
905\end{array}$ & $\begin{array}{c}\mathrm{T}_{\mathrm{T}} \\
105 \mathrm{~s}\end{array}$ & $\begin{array}{r}\mathrm{T}_{\mathrm{g}} \\
120 \mathrm{~s} \\
\end{array}$ & $\begin{array}{r}\mathrm{T}_{\mathrm{Q}} \\
870 \mathrm{~s} \\
\end{array}$ & $\begin{array}{r}T \\
9005 \\
9005\end{array}$ & & & & & \\
\hline HEC 1 & & & & & & & & & & & & & & & \\
\hline SIG 1 & & & & & & & & & & & & & & & $\frac{5}{7}$ \\
\hline MEC 2 & & & & & & & & & & & & & & & s \\
\hline SIG 2 & & & & & & & & & & & & & & & $\frac{7}{1}$ \\
\hline WEC 3 & & & & & & & & & & & & & & & 점 \\
\hline SIG 3 & & & & & & & & & & & & & & & $\underline{ \pm}$ \\
\hline WEC 4 & & & & & & & & & & & & & & & סקי \\
\hline SIG 4 & & & & & & & & & & & & & & & \\
\hline WEC 5 & & & & & & & & & & & & & & & 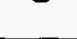 \\
\hline SIG 5 & & & & & & & & & & & & & & & \\
\hline
\end{tabular}

\begin{tabular}{|c|c|c|}
\hline DOCÜMENT NO & REVISTOON & PAGENO \\
\hline HNF-SD - WH-TC-072 & 0 & 45 OF 203 \\
\hline
\end{tabular}


9.29 DATA RECORD SHEET 181

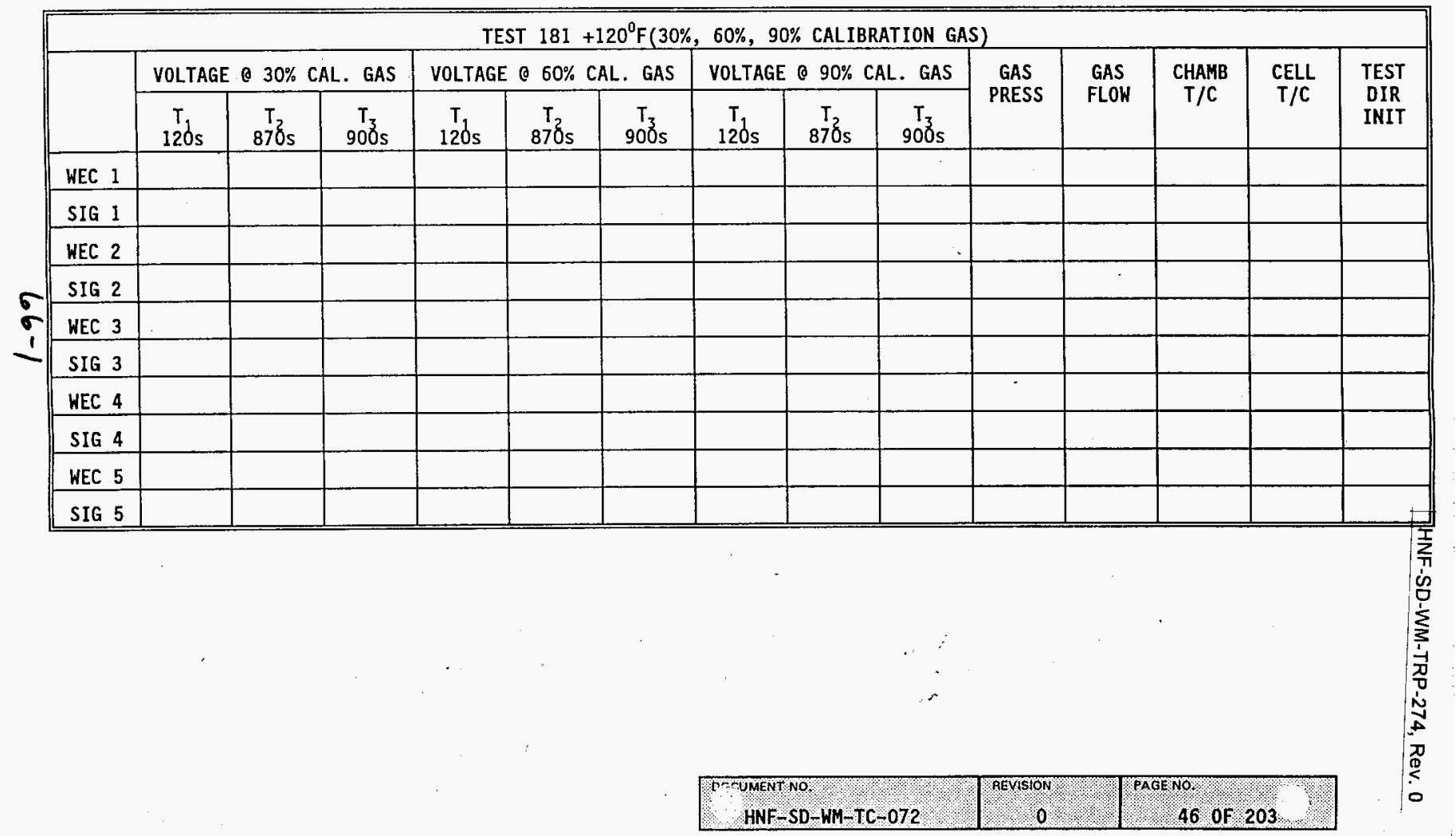


TEST PROCEDURE FOR MEASUREMENT OF PERFORMANCE VS TEMPERATURE WHITTAKER CELL

9.30 DATA RECORD SHEET 182 4.F.Vargof
$1-30$ - ens

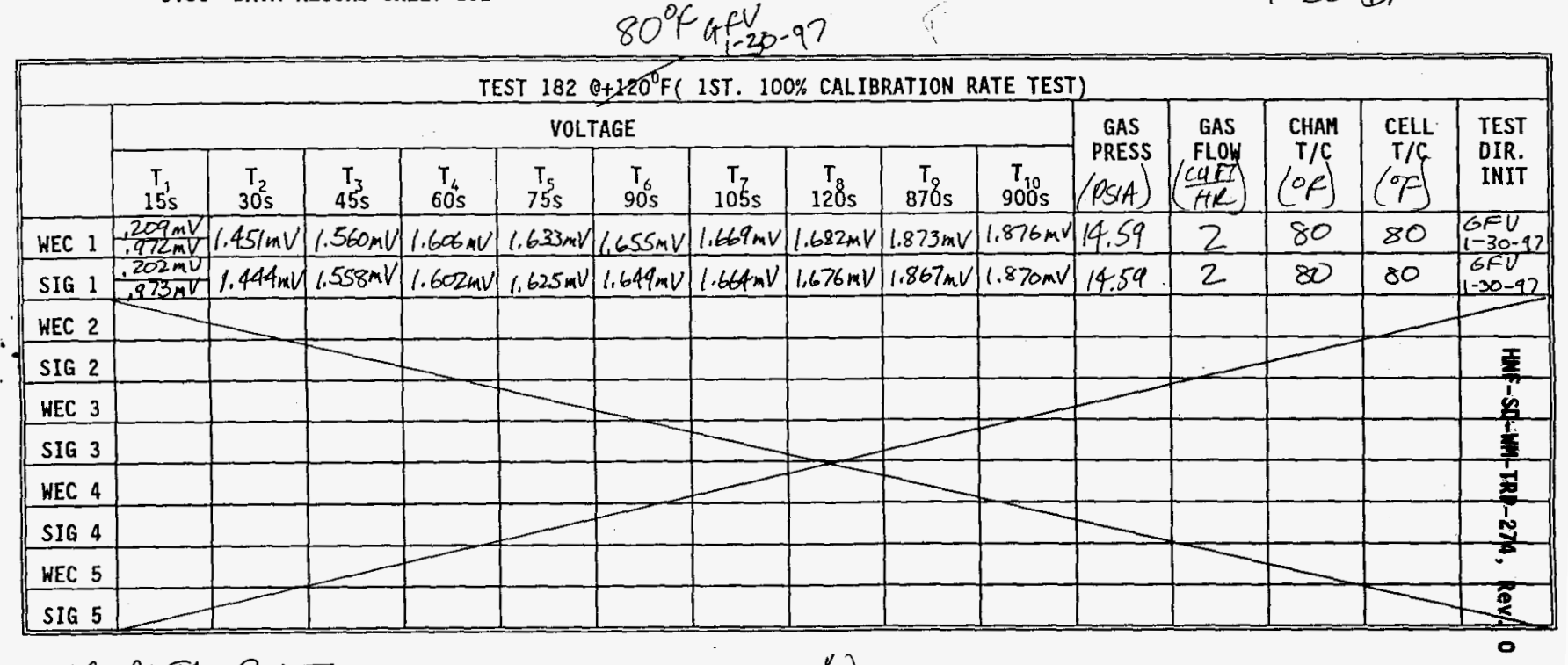

HP DATA FILE

wee 182 - $15+100 \%$ e $80 \%$
Pores

1. UPPEA PSKTIOA OF TI BCOCK is juttar value

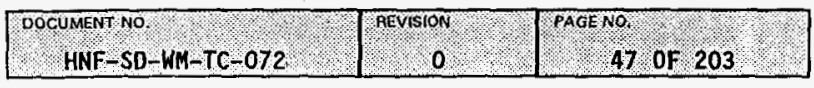


TEST PROCEDURE FOR MEASUREMENT OF PERFORMANCE VS TEMPERATURE WHITAKER CELL

9.31 DATA RECORD SHEET 183

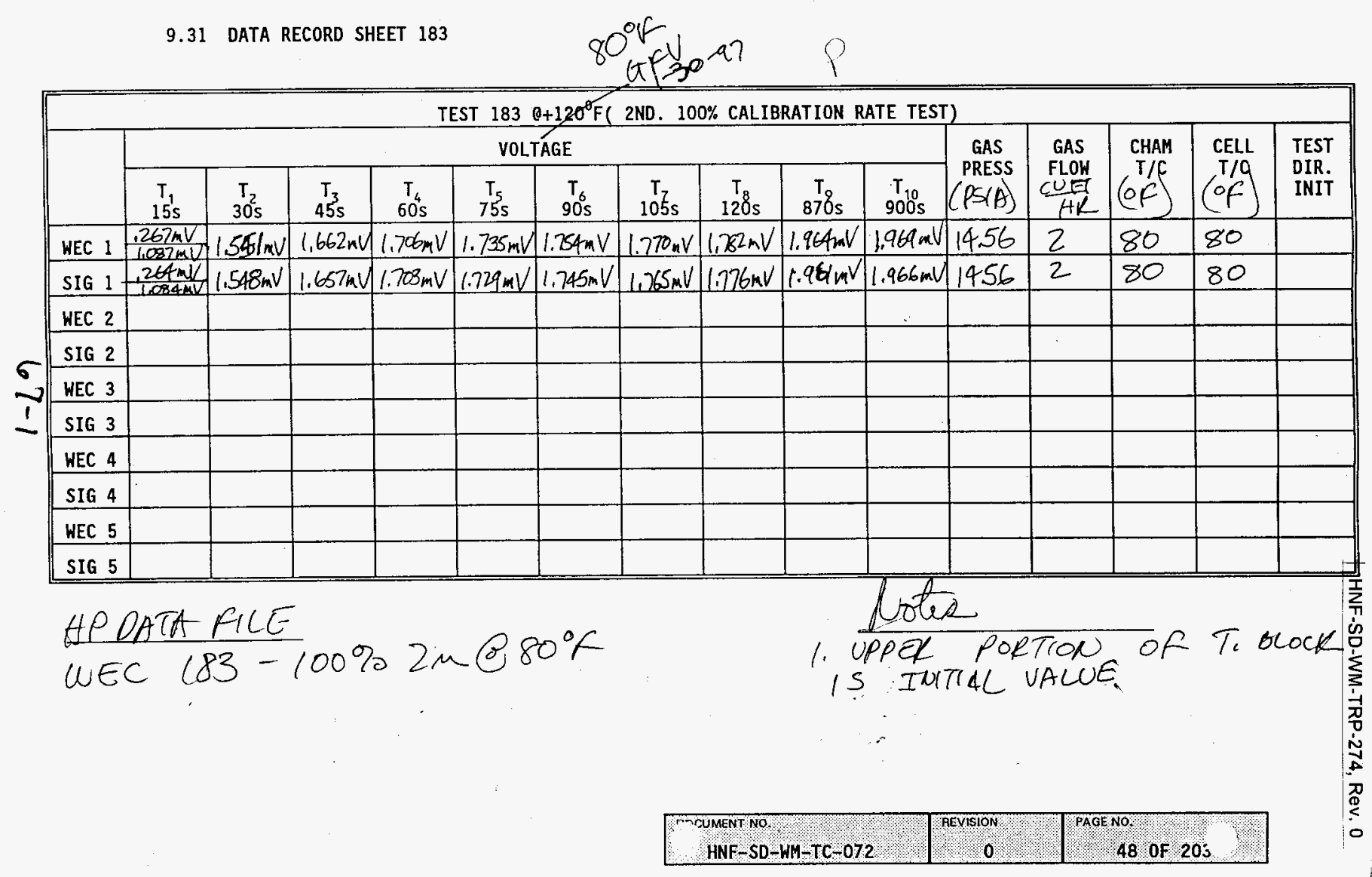




\section{TEST PROCEDURE FOR MEASUREMENT OF PERFORMANCE VS TEMPERATURE} WHITTAKER CELL

\subsection{DATA RECORD SHEET 184}

$$
30^{\circ} \mathrm{F}+50,33^{-97}
$$

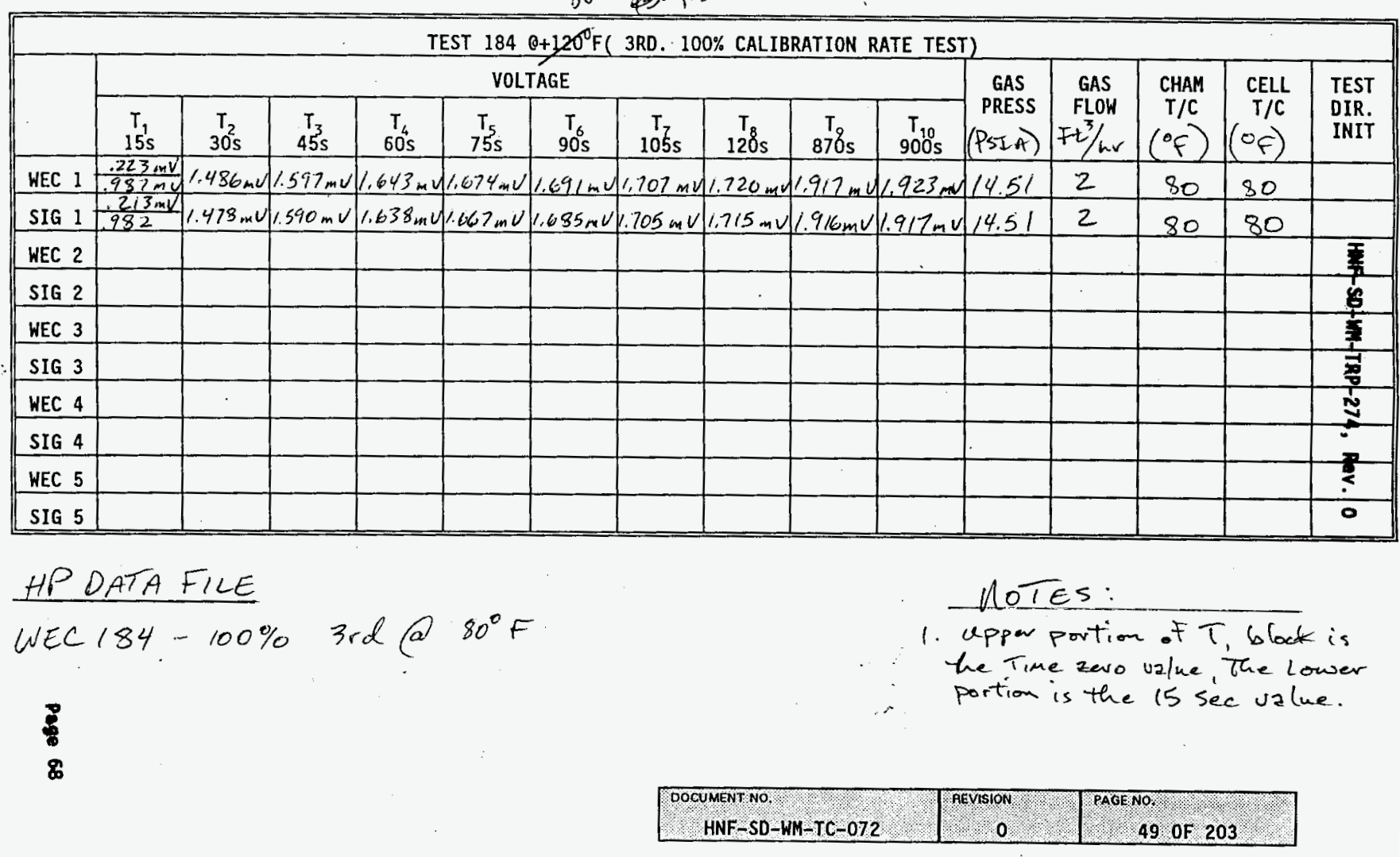




\subsection{DATA RECORD SHEET 211}

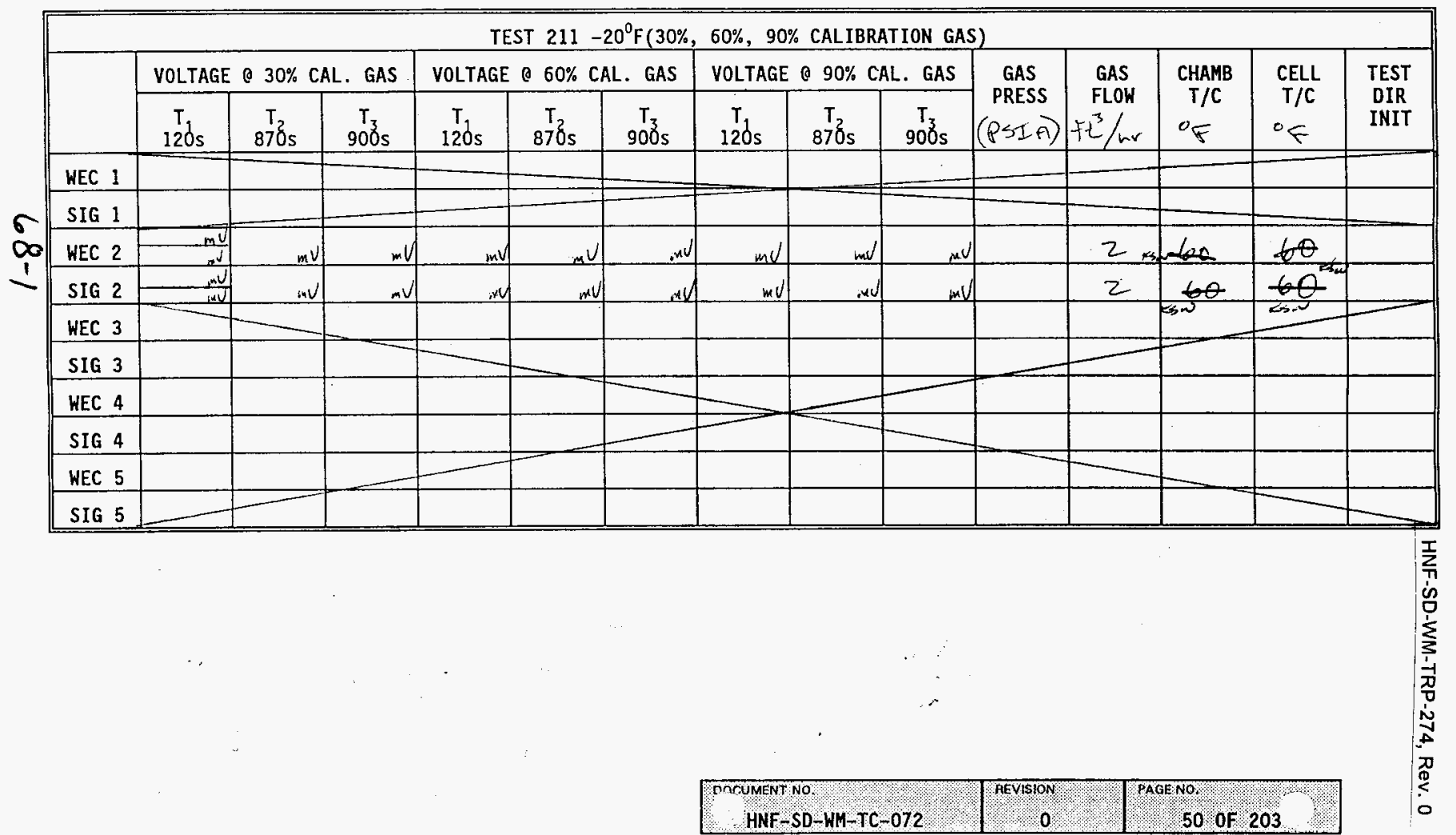




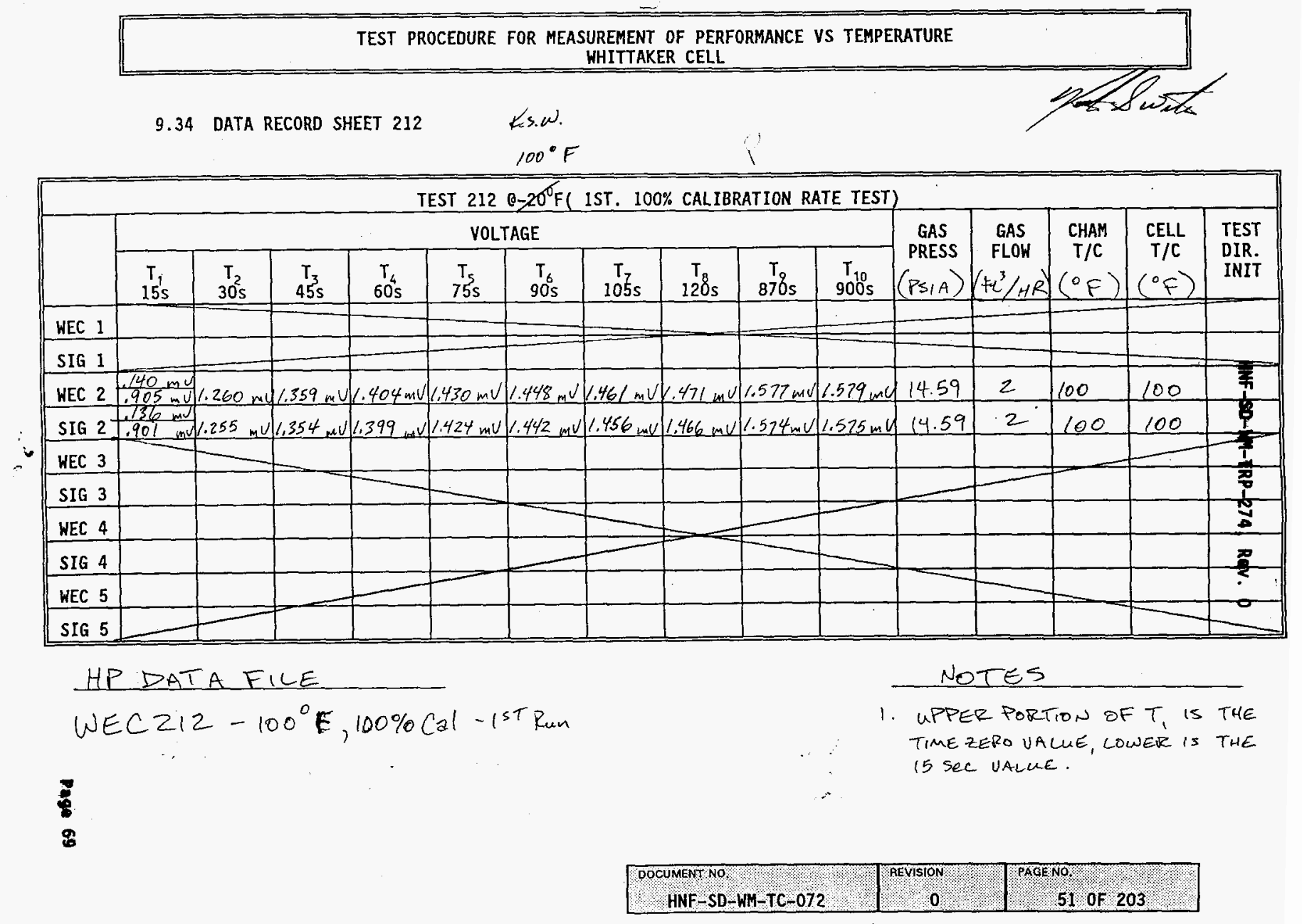


9.35 DATA RECORD SHEET 213

\begin{tabular}{|c|c|c|c|c|c|c|c|c|c|c|c|c|c|c|c|}
\hline \multicolumn{16}{|c|}{ TEST $2130-20^{\circ} \mathrm{F}$ ( 2ND. $100 \%$ CALIBRATION RATE TEST) } \\
\hline & \multicolumn{10}{|c|}{ VOLTAGE } & \multirow{2}{*}{$\begin{array}{c}\text { GAS } \\
\text { PRESS }\end{array}$} & \multirow{2}{*}{$\begin{array}{l}\text { GAS } \\
\text { FLOW }\end{array}$} & \multirow{2}{*}{$\begin{array}{l}\text { CHAM } \\
\mathrm{T} / \mathrm{C}\end{array}$} & \multirow{2}{*}{$\begin{array}{c}\text { CELL } \\
\mathrm{T} / \mathrm{C}\end{array}$} & \multirow{2}{*}{$\begin{array}{l}\text { TEST } \\
\text { DIR. } \\
\text { INIT }\end{array}$} \\
\hline & $\begin{array}{r}\mathrm{T}_{1} \\
15 \mathrm{~s} \\
\end{array}$ & $\begin{array}{r}\mathrm{T}_{2} \\
30 \mathrm{~s} \\
\end{array}$ & $\begin{array}{r}T_{3} \\
45^{3} \mathrm{~s} \\
\end{array}$ & $\begin{array}{r}T_{4} \\
60 \mathrm{~s} \\
\end{array}$ & $\begin{array}{r}T_{5} \\
75 \mathrm{~s} \\
\end{array}$ & $\begin{array}{l}T_{6} \\
905\end{array}$ & $\begin{array}{c}\mathrm{T}_{\mathrm{r}} \\
105 \mathrm{~s}\end{array}$ & $\begin{array}{r}\mathrm{T}_{8} \\
120 \mathrm{~s} \\
\end{array}$ & $\begin{array}{c}\mathrm{T} \\
870 \mathrm{~s} \\
\end{array}$ & $\begin{array}{c}\mathrm{T}_{10} \\
900 \mathrm{~s}\end{array}$ & & & & & \\
\hline \multicolumn{16}{|l|}{ HEC I } \\
\hline \multicolumn{16}{|l|}{ SIG 1} \\
\hline \multicolumn{16}{|l|}{ WEC 2} \\
\hline \multicolumn{16}{|l|}{ SIG 2} \\
\hline \multicolumn{16}{|l|}{ HEC 3} \\
\hline SIG 3 & & & & & & & & & & & & & & & \\
\hline WEC 4 & & & & & & & & & & & & & & & \\
\hline SIG 4 & & & & & & & & & & & & & & & \\
\hline WEC 5 & & & & & & & & & & & & & & & \\
\hline SIG 5 & & & & & & & & & & & & & & & \\
\hline
\end{tabular}




\subsection{DATA RECORD SHEET 214}

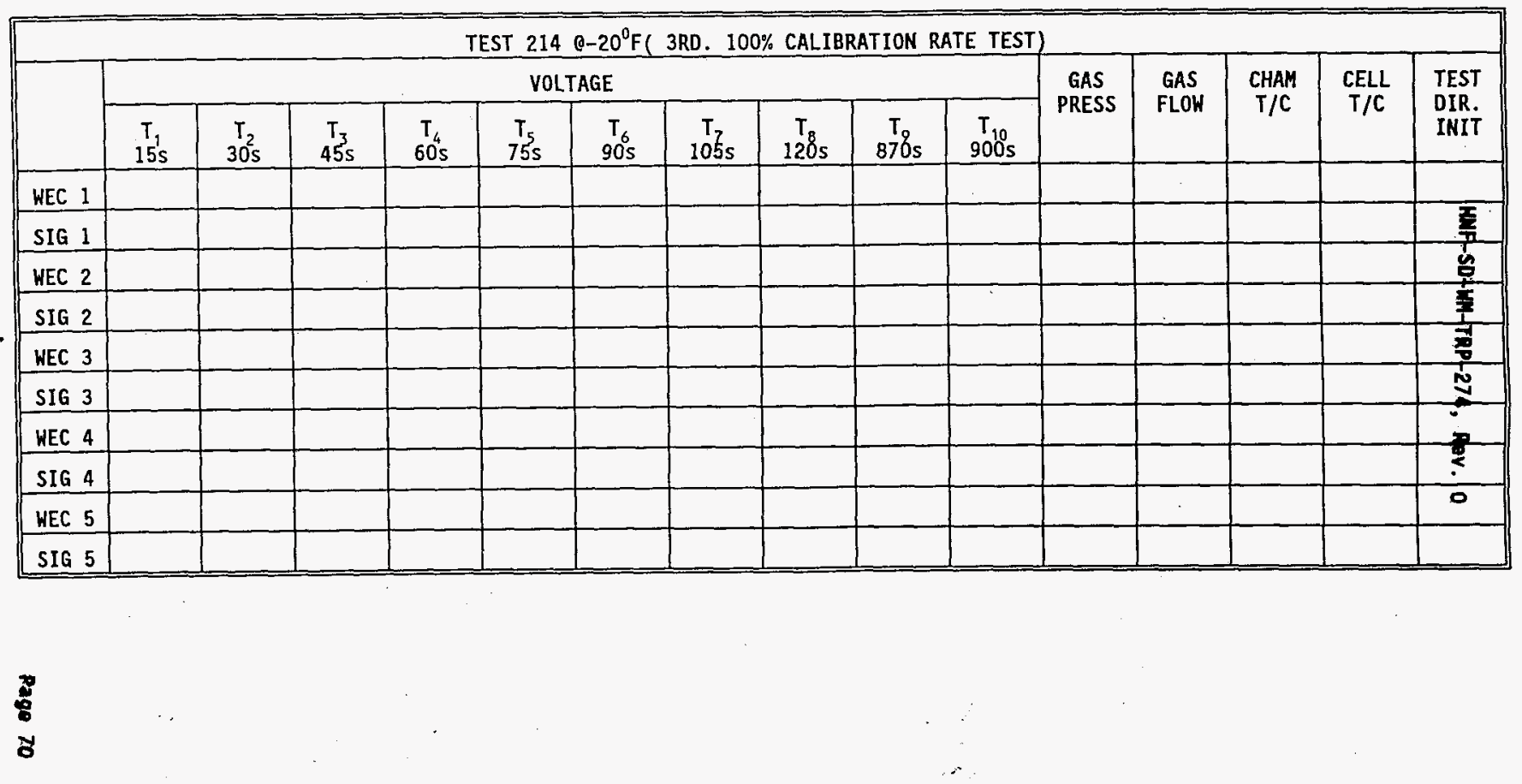




\section{TEST PROCEDURE FOR MEASUREMENT OF PERFORMANCE VS TEMPERATURE}

WHITTAKER CELL

\subsection{DATA RECORD SHEET 221}

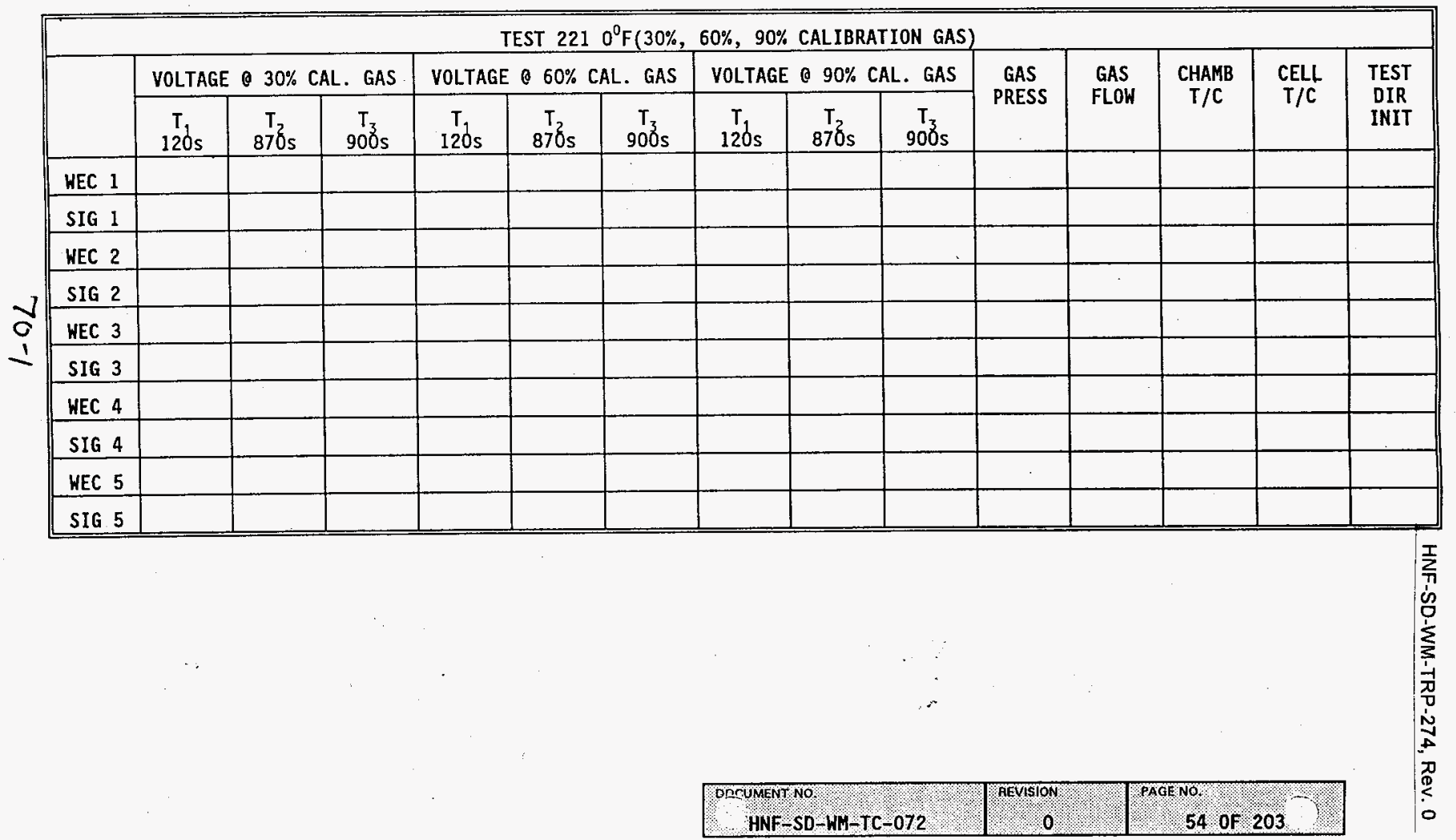




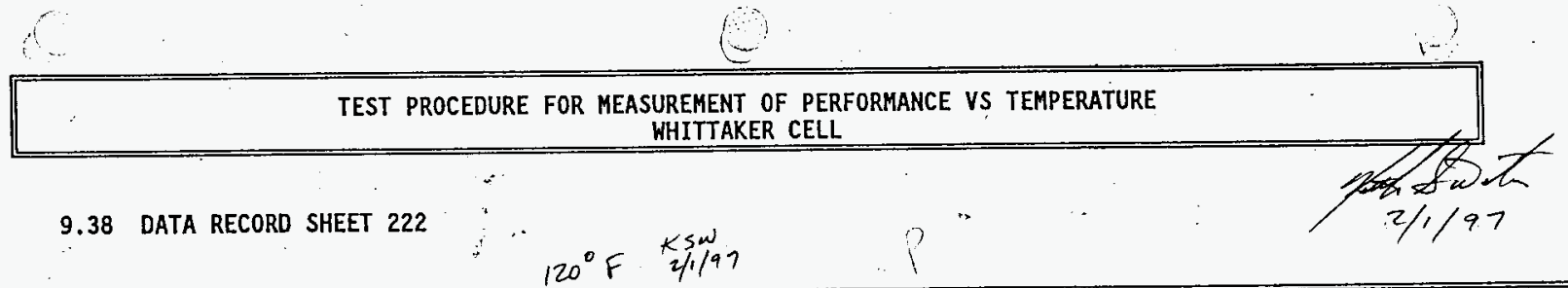

\begin{tabular}{|c|c|c|c|c|c|c|c|c|c|c|c|c|c|c|c|}
\hline \multicolumn{16}{|c|}{ TEST $22290^{\circ} \mathrm{F}$ ( $15 \mathrm{ST} .100 \%$ CALIBRATION RATE TEST) } \\
\hline WEC 1 & & & & & & & & & & & & - & & & \\
\hline SIG 1 & & & & & & & & & & & & & & & \\
\hline WEC 2 & $\frac{.178 \mathrm{mv}}{1.132 \mathrm{mv}}$ & $1.376 \mathrm{~m}$ & $1.443 \mathrm{mV}$ & $1.475 \mathrm{mV}$ & $1.494 \mathrm{~m} \mathrm{~V}$ & $1.509 \mathrm{~m} v$ & $1.519 \mathrm{mV}$ & $1.529 \mathrm{~m}$ & $1.625 \mathrm{ma}$ & $1.626 \mathrm{mv}$ & 14.60 & 2 & 120 & 120 & 4 \\
\hline SIG 2 & $\begin{array}{r}.174 \mathrm{mv} \\
.124 \mathrm{mv} \\
\end{array}$ & $1.373 \mathrm{mV}$ & $1.439 \mathrm{mu}$ & $1.472,4$ & $1.490 \mathrm{mV}$ & $1.506 \mathrm{mu}$ & $\angle .515 \mathrm{mC}$ & $1.525 \mathrm{mV}$ & $6.622 \mathrm{mu}$ & $1,623 \mathrm{mV}$ & 14.60 & 2 & 120 & 120 & \\
\hline WEC 3 & & & & & & & & & & & & & & & \\
\hline SIG 3 & & & & & & & & & & & & & & & \\
\hline WEC 4 & & & & & & & & & & & & & & & \\
\hline SIG 4 & & & & & & & & & & & & & & $\cdots$ & \\
\hline WEC 5 & & & & & & & & & & & & & & & 0 \\
\hline SIG 5 & & & & & & & & & & & & & & & \\
\hline
\end{tabular}

\section{HP DATA FILE}

WEC22Z-15TRUN100\%@120 F
NoTES

1. UPPER PORTION OF $T$, IS FOR time zero value, lowete is for $15 \mathrm{Sec}$ VALUE

จำ 


\subsection{DATA RECORD SHEET 223}

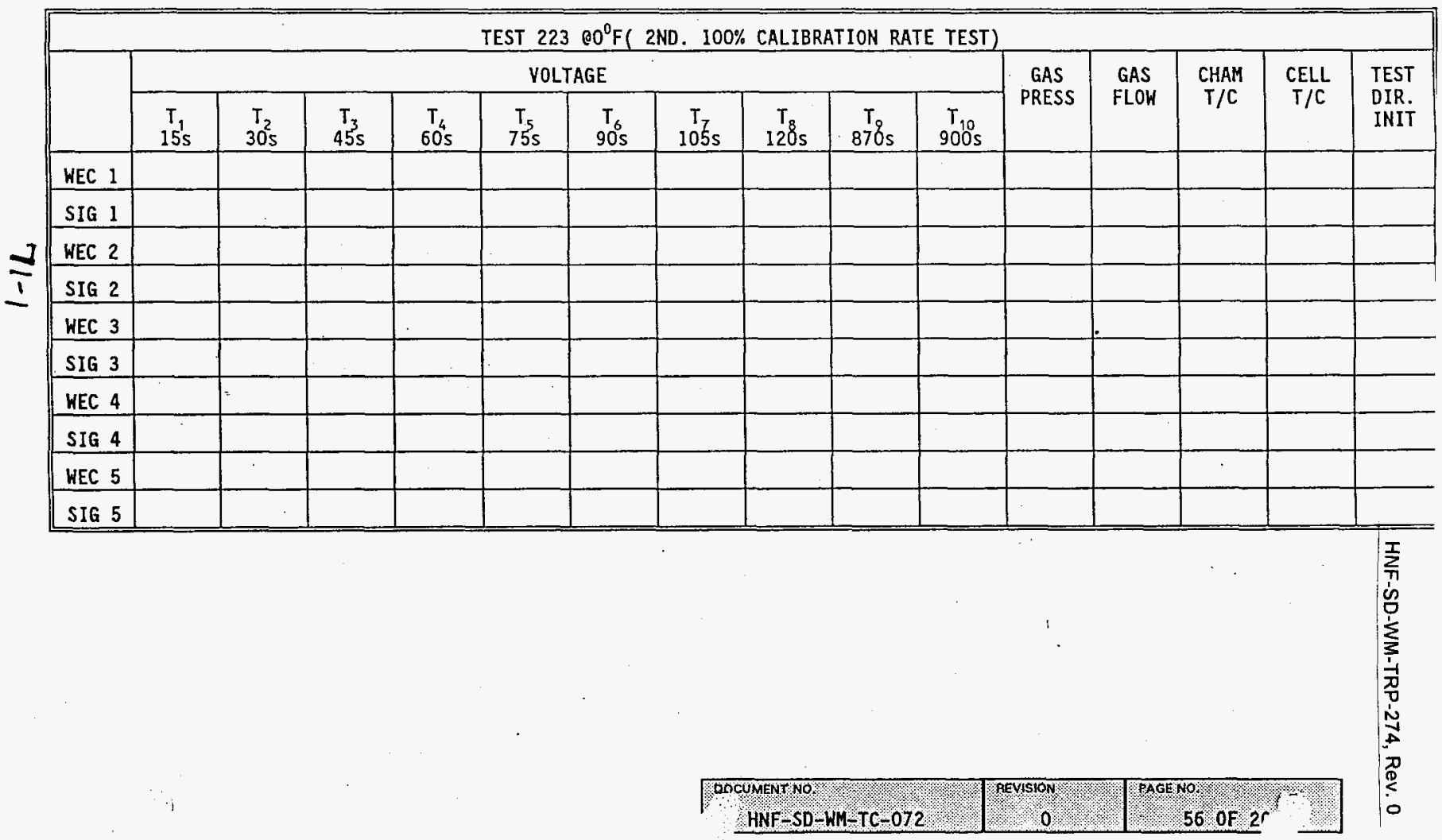




\subsection{DATA RECORD SHEET 231}

\begin{tabular}{||c|c|c|c|c|c|c|c|c|c|c|c|c|c|c|}
\hline \multicolumn{10}{|c|}{ TEST 231 +20 $0^{\circ}$ (30\%, 60\%, 90\% CALIBRATION GAS) } \\
\hline
\end{tabular}




\section{TEST PROCEDURE FOR MEASUREMENT OF PERFORMANCE VS TEMPERATURE}

WHITTAKER CELL

9.42 DATA RECORD SHEET 232

\begin{tabular}{|c|c|c|c|c|c|c|c|c|c|c|c|c|c|c|c|}
\hline \multicolumn{16}{|c|}{ TEST $2320+20^{\circ} \mathrm{F}$ ( $1 \mathrm{ST}$. $100 \%$ CALIBRATION RATE TEST) } \\
\hline & \multicolumn{10}{|c|}{ VOLTAGE } & \multirow{2}{*}{$\begin{array}{c}\text { GAS } \\
\text { PRESS }\end{array}$} & \multirow{2}{*}{$\begin{array}{l}\text { GAS } \\
\text { FLOW }\end{array}$} & \multirow{2}{*}{$\begin{array}{l}\text { CHAM } \\
\mathrm{T} / \mathrm{C}\end{array}$} & \multirow{2}{*}{$\begin{array}{c}\text { CELL } \\
T / C\end{array}$} & \multirow{2}{*}{$\begin{array}{l}\text { TEST } \\
\text { DIR. } \\
\text { INIT }\end{array}$} \\
\hline & $\begin{array}{r}T \\
15 s \\
\end{array}$ & $\begin{array}{r}T_{2} \\
30 s \\
\end{array}$ & $\begin{array}{r}T_{3} \\
45 \mathrm{~s} \\
\end{array}$ & $\begin{array}{r}T_{4} \\
60 \mathrm{~s} \\
\end{array}$ & $\begin{array}{r}T_{5} \\
75 \mathrm{~s} \\
\end{array}$ & $\begin{array}{r}T_{6} \\
90 \mathrm{~s} \\
\end{array}$ & $\begin{array}{c}\mathrm{T}_{\mathrm{T}} \\
105 \mathrm{~s}\end{array}$ & $\begin{array}{r}T_{8} \\
120 \mathrm{~s} \\
\end{array}$ & $\begin{array}{c}\mathrm{T} \\
870 \mathrm{~s}\end{array}$ & $\begin{array}{c}T_{10} \\
900 \mathrm{~s}\end{array}$ & & & & & \\
\hline \multicolumn{16}{|l|}{ WEC 1} \\
\hline SIG 1 & & & & & & & & & & & & & & & 票 \\
\hline \multicolumn{16}{|l|}{ HEC 2} \\
\hline SIG 2 & & & & & & & & & & & & & & & $\frac{1}{3}$ \\
\hline WEC 3 & & & & & & & & & & & & & & & 辛 \\
\hline \multicolumn{16}{|l|}{ SIG 3} \\
\hline \multicolumn{16}{|l|}{ WEC 4} \\
\hline SIG 4 & & & & & & & & & & & & & & & $\stackrel{0}{\varphi}$ \\
\hline WEC 5 & & & & & & & & & & & & & & & 0 \\
\hline$\overline{\text { SIG } 5}$ & & & & & & & & & & & & & & & \\
\hline
\end{tabular}

के
के 
TEST PROCEDURE FOR MEASUREMENT OF PERFORMANCE VS TEMPERATURE WHITTAKER CELL

9.43 DATA RECORD SHEET 233

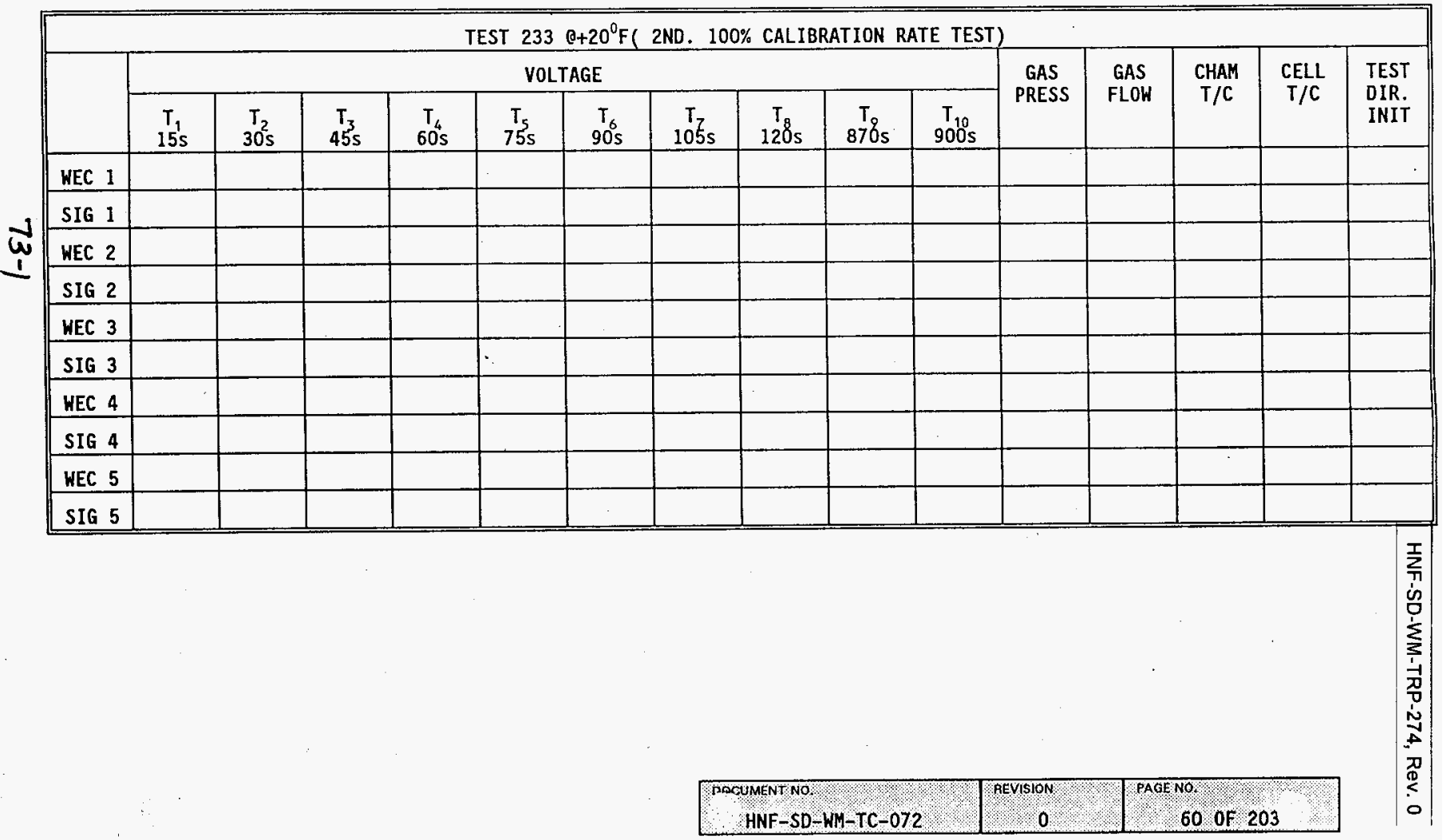




\subsection{DATA RECORD SHEET 234}

\begin{tabular}{|c|c|c|c|c|c|c|c|c|c|c|c|c|c|c|c|}
\hline \multicolumn{16}{|c|}{ TEST $234 \mathrm{C}^{+}+20^{\circ} \mathrm{F}$ (3RD. 100\% CALIBRATION RATE TEST) } \\
\hline & \multicolumn{10}{|c|}{ VOLTAGE } & \multirow{2}{*}{$\begin{array}{l}\text { GAS } \\
\text { PRRESS }\end{array}$} & \multirow{2}{*}{$\begin{array}{l}\text { GAS } \\
\text { FLOW }\end{array}$} & \multirow{2}{*}{ CHAM } & \multirow{2}{*}{ CELL } & \multirow{2}{*}{$\begin{array}{l}\text { TEST } \\
\text { IIR. } \\
\text { INIT }\end{array}$} \\
\hline & $\underset{15 s}{T}$ & $\begin{array}{c}T_{2} \\
305\end{array}$ & ${ }_{455}^{T}$ & ${ }_{60}^{T_{6}^{6}}$ & $\begin{array}{c}T_{5} \\
75 s\end{array}$ & $\begin{array}{l}T_{6} \\
90^{6}\end{array}$ & $\begin{array}{c}T_{1} \xi_{5} \\
1055\end{array}$ & $\begin{array}{c}\mathrm{T}_{8} \\
12 \mathrm{~s}\end{array}$ & ${ }_{870 \mathrm{~s}}^{\top}$ & $\begin{array}{c}T_{100} \\
900 \mathrm{~s}\end{array}$ & & & & & \\
\hline \multicolumn{16}{|l|}{ HEC 1} \\
\hline \multicolumn{16}{|l|}{$\operatorname{SIG} 1$} \\
\hline \multicolumn{16}{|l|}{ HEC 2} \\
\hline \multirow{2}{*}{\multicolumn{16}{|c|}{$\begin{array}{ll}\text { SIG } 2 \\
\text { HEC }\end{array}$}} \\
\hline & & & & & & & & & & & & & & & $\frac{1}{3}$ \\
\hline \multicolumn{16}{|l|}{ SIG 3} \\
\hline \multicolumn{16}{|l|}{ KEC 4} \\
\hline SIG 4 & & & & & & & & & & & & & & & 疍 \\
\hline HEC 5 & & & & & & & & & & & & & & & 으 \\
\hline SIG 5 & & & & & & & & & & & & & & & \\
\hline
\end{tabular}

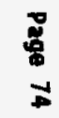


TEST PROCEDURE FOR MEASUREMENT OF PERFORMANCE VS TEMPERATURE WHITTAKER CELL

9.45 DATA RECORD SHEET 241

G.Flangof

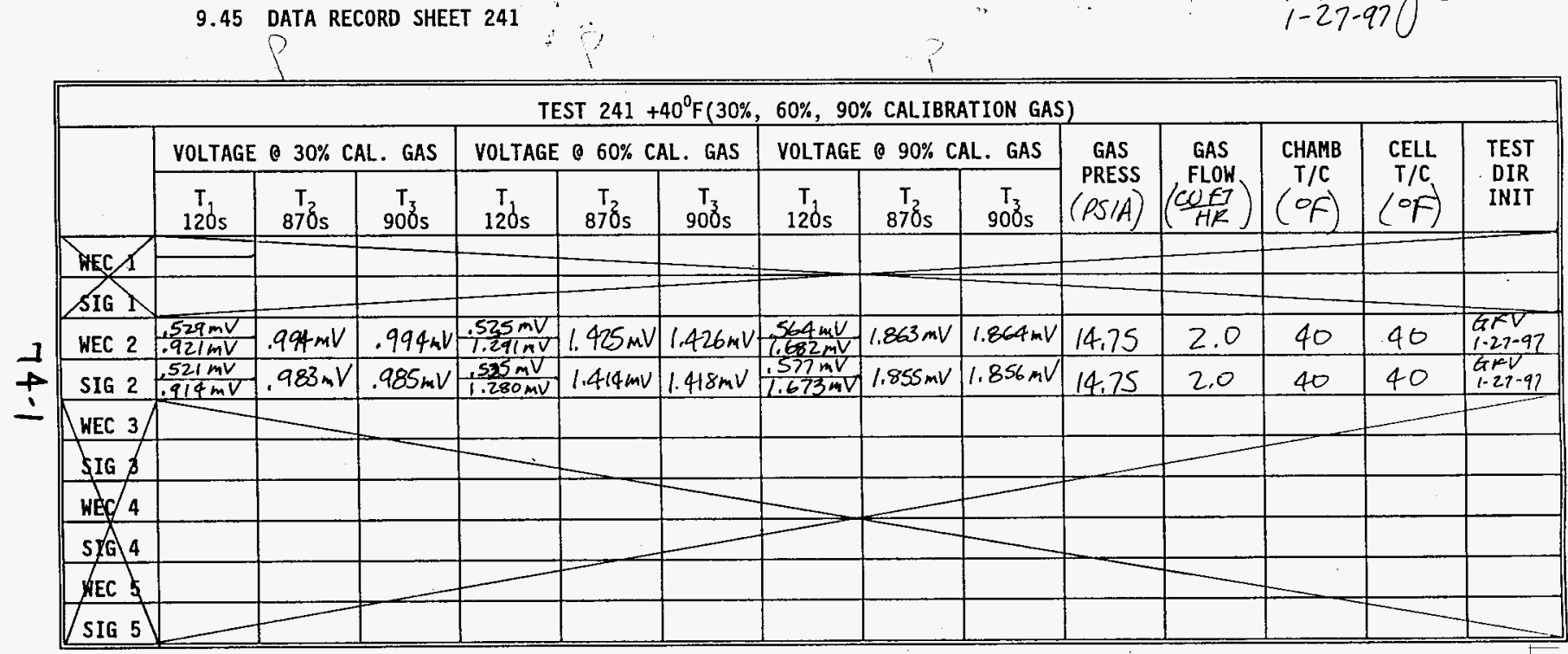

HP OATA FILES

WEC 241A-30\%

wec $2416-60 \%$

weC $241 C-90 \%$
1. upper poktion of tiblock is inttal value.

\begin{tabular}{|c|l|l|l|}
\hline DOCUMENT NO \\
HNF-SD-WH-TC-072
\end{tabular} 
TEST PROCEDURE FOR MEASUREMENT OF PERFORMANCE VS TEMPERATURE WHITAKER CELL

9.46 DATA RECORD SHEET 242

$$
\text { G.F.Varges }
$$

TEST $2420+40^{\circ} \mathrm{F}$ ( 1 ST. $100 \%$ CALIBRATION RATE TEST)

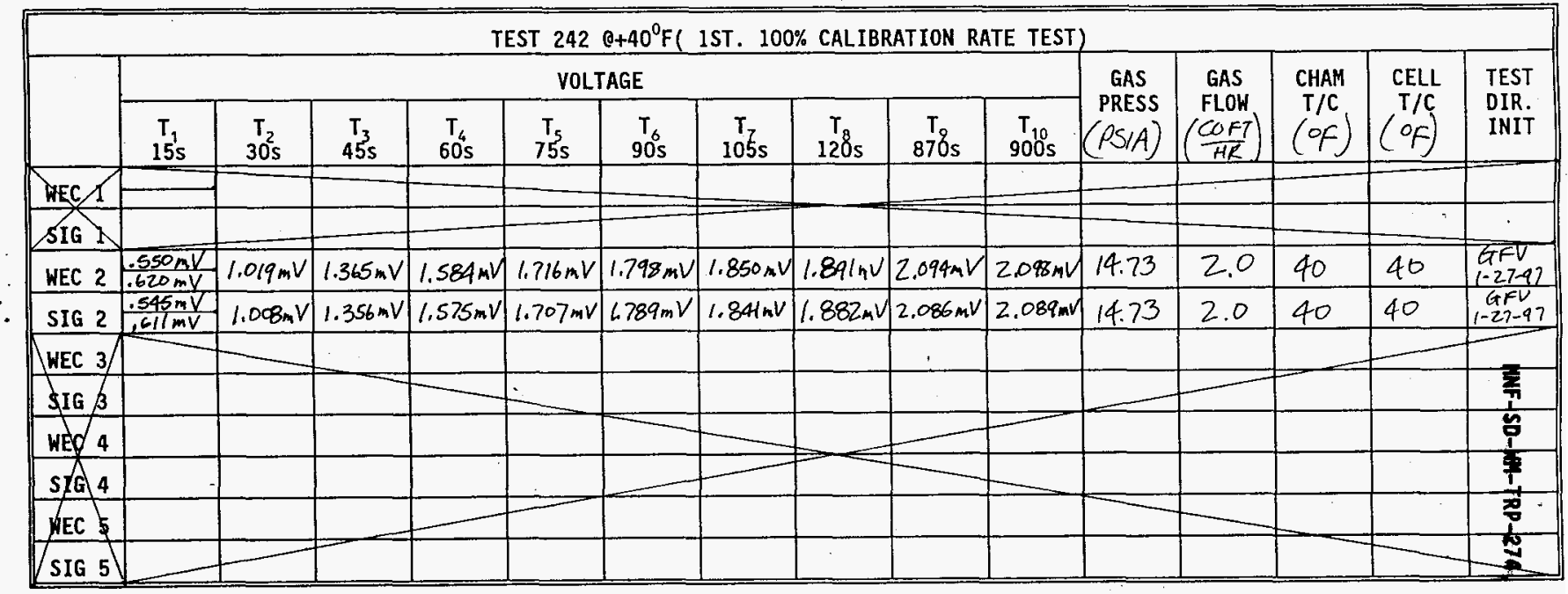

HP DATA FILES

$\therefore$ WE C $242-$ l st $100 \%$
1. UPPER PORTION OF TI BLCCK IS INTTLL VALUE:

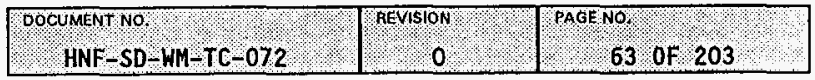


TEST PROCEDURE FOR MEASUREMENT OF PERFORMANCE VS TEMPERATURE WHITAKER CELL

9.47 DATA RECORD SHEET 243

4.F.Vargof

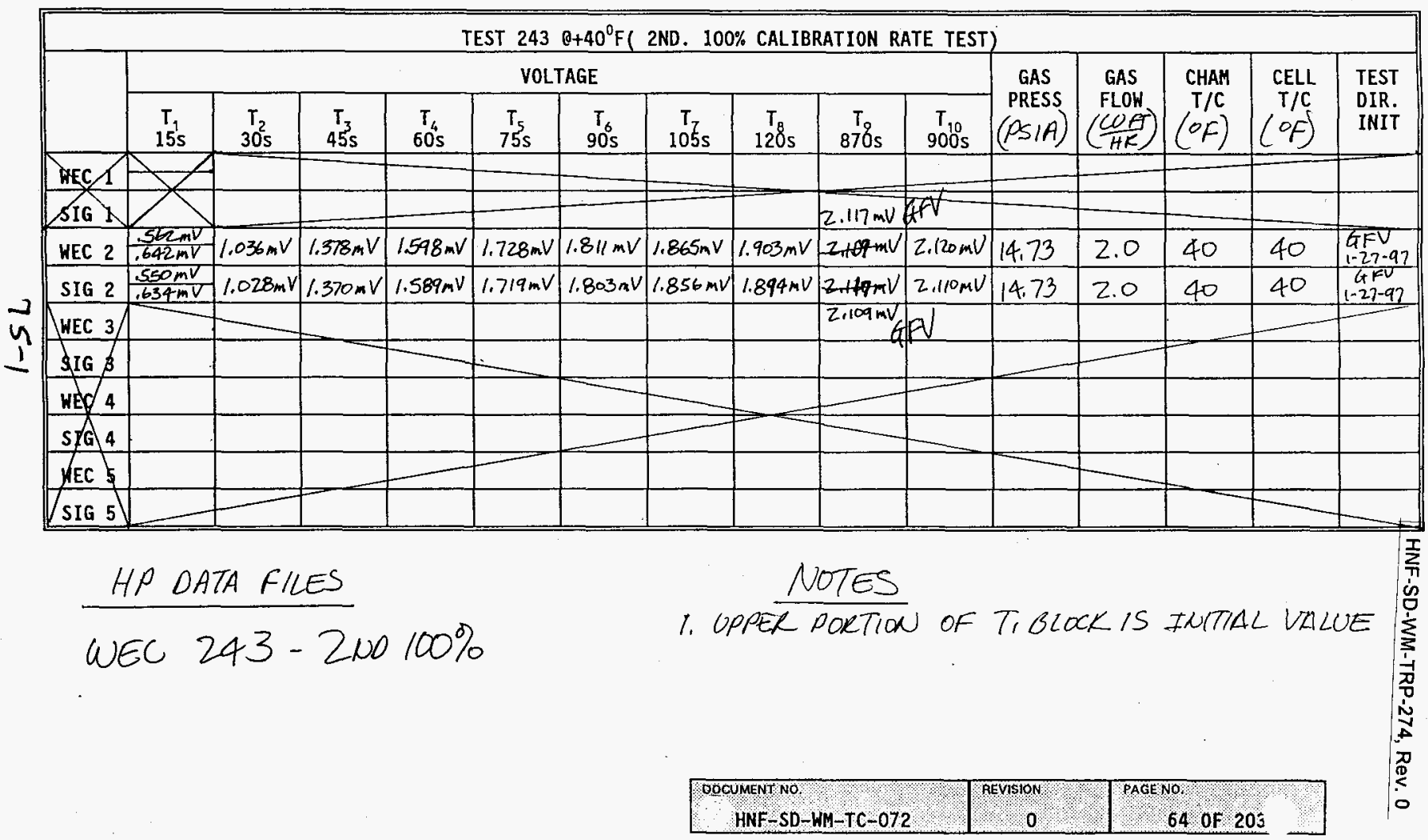


TEST PROCEDURE FOR MEASUREMENT OF PERFORMANCE VS TEMPERATURE WHITTAKER CELL

9.48 DATA RECORD SHEET 244 A.t. Varcob

TEST $2440+40^{\circ} \mathrm{F}$ (3RD. $100 \%$ CALIBRATION RATE TEST) VOLTAGE

\begin{tabular}{|c|c|c|c|c|c|c|c|c|c|c|c|c|c|c|}
\hline & & & & & VOL & AGE & & & & & GAS & GAS & CHAM & CELL \\
\hline & ${ }_{15}^{T} \mathrm{~s}$ & $\begin{array}{c}T_{2} \\
30^{2} \mathrm{~s}\end{array}$ & $\begin{array}{r}T_{3} \\
45 s \\
\end{array}$ & $\begin{array}{c}T_{4} \\
605\end{array}$ & $\begin{array}{c}T_{5} \\
755\end{array}$ & $\begin{array}{c}T_{6} \\
90 s\end{array}$ & ${ }_{105 \mathrm{~s}}$ & $\begin{array}{c}T_{8} \\
120 \mathrm{~s} \\
\end{array}$ & $\begin{array}{c}T_{8} \\
870 \mathrm{~s}\end{array}$ & $\begin{array}{c}T_{10} \\
900 \mathrm{~s}\end{array}$ & $(\rho S / A)$ & $\left(\frac{10}{H K}\right)$ & & \\
\hline HEC $\angle 1$ & & & & & & & & & & & & & & \\
\hline SIG & & & & $G+V$ & & & & & & & & & & \\
\hline HEC 2 & $\frac{.57\left(\frac{\mathrm{mV}}{.646 \mathrm{mV}}\right.}{}$ & $1.034 \mathrm{mV}$ & $1.377 \mathrm{mV}$ & $+.584 \mathrm{mV}$ & $1.728 \mathrm{mV}$ & $1.812 \mathrm{mV}$ & $1.868 \mathrm{mV}$ & $1.906 \mathrm{mV}$ & $2.125 \mathrm{mV}$ & $2.124 \mathrm{mV}$ & 14.72 & 2.0 & 40 & 40 \\
\hline SIG 2 & $\begin{array}{r}.56 \times \mathrm{mV} \\
.639 \mathrm{mV}\end{array}$ & $1.026 \mathrm{mV}$ & $1.368 \mathrm{mV}$ & $1.584 \mathrm{mV}$ & $1.720 \mathrm{mV}$ & $1.803 \mathrm{mV}$ & $1,860 \mathrm{mV}$ & $1.897 \mathrm{mV}$ & $2.116 \mathrm{mV}$ & $\mathrm{z.11} / \mathrm{mV}$ & 14.72 & 2.0 & 40 & 40 \\
\hline HEC 3 & & & & & & & & & & & & & & \\
\hline SIG $\beta$ & & & & & & & & & & & & & & \\
\hline WEd 4 & & & & & & & & & & & & & & \\
\hline SIG 4 & & & & & & & & & & & & & & \\
\hline c 5 & & & 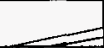 & & & & & & & & & & & \\
\hline IG 5 & & & & & & & & & & & & & & \\
\hline
\end{tabular}

HP DATA FILES

WEC 244 - 3RD $100 \%$

1. UPPER PORTION OF. TI BLOCK IS INTTILL VALL

ํํำ
ने 


\begin{tabular}{|c|c|c|c|c|c|c|c|c|c|c|c|c|c|c|}
\hline & & & & & & & & & & & & & & S YIS \\
\hline & & & & & & & & & & & & & & G J3M \\
\hline & & & & & & & & & & & & & & $\square$ IIS \\
\hline & & & & & & & & & & & & & & $\nabla J 9 M$ \\
\hline & & & & & & & & & & & & & & $\varepsilon$ IIS \\
\hline & & & & & & & & & & & & & & $\varepsilon \mathrm{JJM}$ \\
\hline & & & & & & & & & & & & & & 2 פIS \\
\hline & & & & & & & & & & & & & & $2 \mathrm{JJM}$ \\
\hline & & & & & & & & & & & & & & I FIS \\
\hline & & & & & & & & & & & & & & I J JMM \\
\hline \multirow{2}{*}{$\begin{array}{l}\text { IINI } \\
\text { XIO } \\
\text { IS } 1\end{array}$} & \multirow{2}{*}{$\begin{array}{c}5 / 1 \\
7173\end{array}$} & \multirow{2}{*}{$\begin{array}{c}2 / 1 \\
\text { gWVHJ }\end{array}$} & \multirow{2}{*}{$\begin{array}{l}\text { Mo7. } \\
\text { SWg }\end{array}$} & \multirow{2}{*}{$\begin{array}{c}\text { ss } 3 y d d \\
\text { sHg }\end{array}$} & $\begin{array}{c}\text { solo6 } \\
\sum_{1}\end{array}$ & $\mathrm{~s}_{\perp} \mathrm{Q}_{1}$ & sozI & $\begin{array}{c}5006 \\
\Sigma_{1}\end{array}$ & $\mathrm{~s}_{1}^{\mathrm{s} / 8}$ & ${ }_{1}^{s p 2 I}$ & $\begin{array}{c}\text { solob } \\
\perp\end{array}$ & $\mathrm{s}_{1}^{5018}$ & spZI & \\
\hline & & & & & \multicolumn{3}{|c|}{ S४9 • • } & \multicolumn{3}{|c|}{ 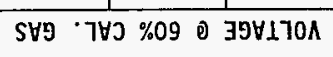 } & \multicolumn{3}{|c|}{ SHY ' } & \\
\hline
\end{tabular}




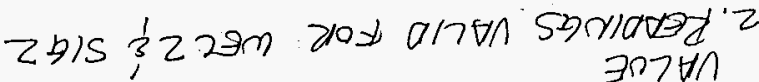

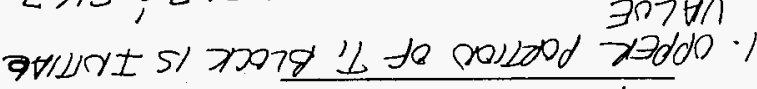

$$
\begin{aligned}
& \% 00 / 151-25223 m
\end{aligned}
$$

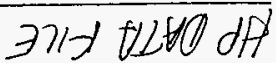

安

\begin{tabular}{|c|c|c|c|c|c|c|c|c|c|c|c|c|c|c|c|}
\hline 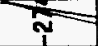 & $\widetilde{S}$ & & & & & & & & & & & & 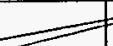 & 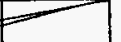 & S YIS \\
\hline 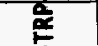 & & & 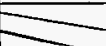 & 7 & & & & & & & 7 & & & & 9 $23 M$ \\
\hline$\frac{1}{4}$ & & & . & 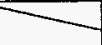 & 7 & - & & $\longrightarrow$ & 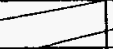 & - & & & & & 7 IIS \\
\hline के & & & & & & $\$<$ & & 34 & 2 & & & & & & $\square \mathrm{JPM}$ \\
\hline 董 & & & 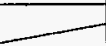 & & & 8 & & 2 & & & 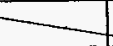 & & & & $\varepsilon$ IIS \\
\hline & 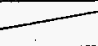 & & & T & & & & & & 3 & & & & & $\varepsilon \mathrm{J} \mathrm{MM}$ \\
\hline $\begin{array}{ll}\cos 82-1 \\
x \rightarrow b 2\end{array}$ & OS & OS & $\sum$ & 2861 & $\pi w / 8 b^{\circ}$ & $\Lambda \times b<b^{\prime} \mid$ & 14SLLV & $\bar{M}^{m}<p^{\prime} \mid$ & $\Lambda^{w} \| L^{\prime}$ & $\Lambda^{14} E 59 \%$ & AWOAST & $A N g \varepsilon^{\prime \prime}$ & $\Lambda^{\omega}\left(90^{\circ}\right)$ & 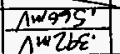 & 2 OIS \\
\hline$\frac{10-82-1}{4-1}$ & 05 & OS & 2 & $28 \times 1$ & Amobb' & 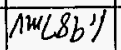 & $\mu^{m} \angle L^{\prime} 1$ & 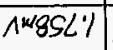 & 1wozl' & hwe $(99)$ & 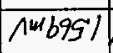 & hwortil & $1 \overline{1004}$ & 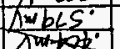 & $2 \mathrm{JIM}$ \\
\hline & & & & & & & & & & & & & & & I פIS \\
\hline & & & & & & & & & & & & & & & I $\mathrm{JJM}$ \\
\hline IINI & $(-t)$ & $\left(t_{0}\right)$ & $\left(\frac{2 H}{900}\right)$ & $(t / s d)$ & $\begin{array}{l}5006 \\
01\end{array}$ & $\mathrm{~s}_{1}^{\mathrm{s} L 8}$ & $\begin{array}{c}\text { sozz } \\
1\end{array}$ & squot & $\begin{array}{l}506 \\
q_{1}\end{array}$ & $\begin{array}{l}s g_{1} L \\
s_{1}\end{array}$ & $\begin{array}{l}509 \\
11\end{array}$ & हst & $\begin{array}{l}\text { SOE } \\
{ }_{2}^{2}\end{array}$ & $\begin{array}{l}\text { sqI }_{1} \\
\text { lst }_{1}\end{array}$ & \\
\hline $1 S 31$ & $7 / 1$ & WWHO & SWg & $\begin{array}{l}\text { SWg } \\
\text { SWg }\end{array}$ & & & & & ב & $170 \AA$ & & & & & \\
\hline
\end{tabular}

59100

$$
\begin{aligned}
& \text { Yosmon-ty } \\
& \Lambda+\infty \text { tos . }
\end{aligned}
$$


HNF-SD-WM-TPP- 274 Rev. 0

This Page intentionally blank 
TEST PROCEDURE FOR MEASUREMENT OF PERFORMANCE VS TEMPERATURE

WHITTAKER CELL

\subsection{DATA RECORD SHEET 254}

TEST $2540+60^{\circ} \mathrm{F}$ (3RD. 100\% CALIBRATION RATE TEST)

\begin{tabular}{|c|c|c|c|c|c|c|c|c|c|c|c|c|c|c|c|}
\hline & \multicolumn{10}{|c|}{ VOLTAGE } & \multirow{2}{*}{$\begin{array}{c}\text { GAS } \\
\text { PRESS }\end{array}$} & \multirow{2}{*}{$\begin{array}{l}\text { GAS } \\
\text { FLOW }\end{array}$} & \multirow{2}{*}{$\begin{array}{c}\text { CHAM } \\
\mathrm{T} / \mathrm{C}\end{array}$} & \multirow{2}{*}{$\begin{array}{c}\text { CELL } \\
\mathrm{T} / \mathrm{C}\end{array}$} & \multirow{2}{*}{$\begin{array}{l}\text { TEST } \\
\text { DIR. } \\
\text { INIT }\end{array}$} \\
\hline & $\begin{array}{c}T_{1} \\
15 s \\
\end{array}$ & $\begin{array}{r}\mathrm{T}_{2} \\
30 \mathrm{~s} \\
\end{array}$ & $\begin{array}{r}T_{3} \\
45 s \\
\end{array}$ & $\begin{array}{r}T_{4} \\
60 \mathrm{~s} \\
\end{array}$ & $\begin{array}{r}T_{5} \\
75 \mathrm{~s} \\
\end{array}$ & $\begin{array}{r}\mathrm{T}_{6} \\
90 \mathrm{~s} \\
\end{array}$ & ${ }_{105}^{\mathrm{T}} \mathrm{s}$ & $\begin{array}{c}\mathrm{T}_{8} \\
120 \mathrm{~s} \\
\end{array}$ & $\begin{array}{c}\mathrm{T} \\
870 \mathrm{~s} \\
\end{array}$ & $\begin{array}{r}T_{10} \\
900 \mathrm{~s} \\
\end{array}$ & & & & & \\
\hline \multicolumn{16}{|l|}{ WEC 1} \\
\hline \multicolumn{16}{|l|}{ SIG 1} \\
\hline \multicolumn{16}{|l|}{ WEC 2} \\
\hline \multicolumn{16}{|l|}{ SIG 2} \\
\hline \multicolumn{16}{|l|}{ HEC 3} \\
\hline \multicolumn{16}{|l|}{ SIG 3} \\
\hline \multicolumn{16}{|l|}{ WEC 4} \\
\hline \multicolumn{16}{|l|}{ SIG 4} \\
\hline WEC 5 & & & & & & & & & & & & & & & 0 \\
\hline SIG 5 & & & & & & & & & & & & & & & \\
\hline
\end{tabular}

HP DATA FILE

NOTES

1

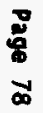




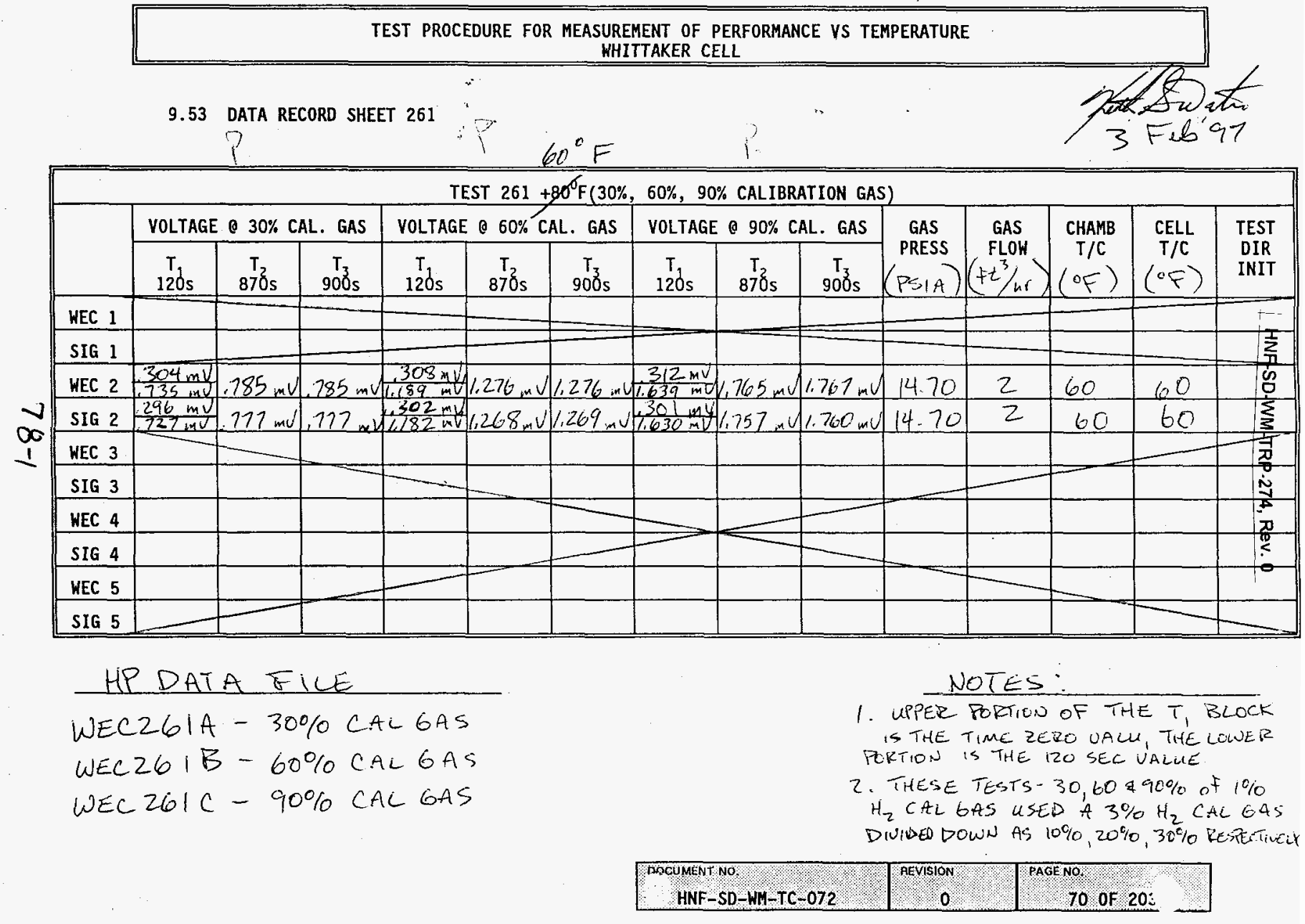


TEST PROCEDURE FOR MEASUREMENT OF PERFORMANCE VS TEMPERATURE

WHITTAKER CELL

9.54 DATA RECORD SHEET 262

$60^{\circ} \mathrm{F}$

$n$

bave

TEST $2620+80^{\circ} \mathrm{F}$ (1ST. $100 \%$ CALIBRATION RATE TEST)

\begin{tabular}{|c|c|c|c|c|c|c|c|c|c|c|c|c|c|c|c|}
\hline & \multicolumn{10}{|c|}{ VOLTAGE } & \multirow{2}{*}{$\begin{array}{c}\text { GAS } \\
\text { PRESS } \\
(P S, P)\end{array}$} & \multirow{2}{*}{$\begin{array}{l}\text { GAS } \\
\text { FLOW } \\
5 i^{3} / \mathrm{hr}\end{array}$} & \multirow{2}{*}{$\begin{array}{c}\text { CHAM } \\
\text { T/C } \\
\left({ }^{\circ} F\right)\end{array}$} & \multirow{2}{*}{$\begin{array}{c}\text { CELL } \\
T / C \\
\left({ }^{\circ} F\right)\end{array}$} & \multirow{2}{*}{$\begin{array}{l}\text { TEST } \\
\text { DIR. } \\
\text { INIT }\end{array}$} \\
\hline & $\begin{array}{c}T_{1} \\
15 s \\
\end{array}$ & $\begin{array}{r}\mathrm{T}_{2} \\
30 \mathrm{~s} \\
\end{array}$ & $\begin{array}{r}T_{3} \\
45 s \\
\end{array}$ & $\begin{array}{r}T_{4} \\
60 \mathrm{~s} \\
\end{array}$ & $\begin{array}{r}T_{5} \\
75 s \\
\end{array}$ & $\begin{array}{r}T_{6} \\
90 \mathrm{~s} \\
\end{array}$ & $\begin{array}{c}\mathrm{T}_{7} \\
105 \mathrm{~s} \\
\end{array}$ & $\begin{array}{r}T_{8} \\
120 \mathrm{~s} \\
\end{array}$ & $\begin{array}{r}T_{g_{2}} \\
870 \mathrm{~s} \\
\end{array}$ & $\begin{array}{r}\mathrm{T}_{10} \\
900 \mathrm{~s} \\
\end{array}$ & & & & & \\
\hline WEC 1 & & & & & & & & & 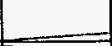 & & & & & & \\
\hline SIG 1 & & & & & & & & & & & & & & & 工立 \\
\hline WEC 2 & $.317 \mathrm{mb}$ & $1.142 \mathrm{mb}$ & $1.417 \mathrm{mV}$ & $1.547 \mathrm{~m}$ & $1.617 \mathrm{mc}$ & $1.659 \mathrm{ac}$ & $1.690 \mathrm{ml}$ & $1.70 \mathrm{mb}$ & $1.853 \mathrm{mv}$ & $1.854 \mathrm{me}$ & 14.80 & 2 & 60 & 60 & is \\
\hline SIG 2 & $\frac{312}{1594=0}$ & $1.137 \mathrm{mb}$ & $1.411 \mathrm{mv}$ & $1.542 \mathrm{mV}$ & $1.613 \mathrm{nV}$ & $.652 \mathrm{mV}$ & $1.483 \mathrm{mb}$ & $1.705_{\mathrm{nV}}$ & $.847 \mathrm{mu}$ & $1.847 \mathrm{me}$ & 14.80 & 2 & 60 & 60 & $\frac{1}{3}$ \\
\hline WEC 3 & & & & & & & & & & & & & & $\longrightarrow$ & 童 \\
\hline SIG 3 & & & & & E & & & & & & & & & & $\stackrel{1}{*}$ \\
\hline HEC 4 & & & & & & & & & & & & & & & \\
\hline SIG 4 & & & & & & & & & & & & & & & 要 \\
\hline WEC 5 & & & & & & & & & & & & 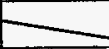 & & & 0 \\
\hline SIG 5 & & & & & & & & & & & & & & & \\
\hline
\end{tabular}

HP DATA FILE

WEC $26211^{5 T} 100 \% @ 60^{\circ} \mathrm{F}$

:
NOTES

1. UPPER PORTION OF $T$,

BLOCK is TIME zero valie, LOWER PORTION IS 15 SEC UALUC. 
TEST PROCEDURE FOR MEASUREMENT OF PERFORMANCE VS TEMPERATURE

WHITTAKER CELL

\subsection{DATA RECORD SHEET 263}

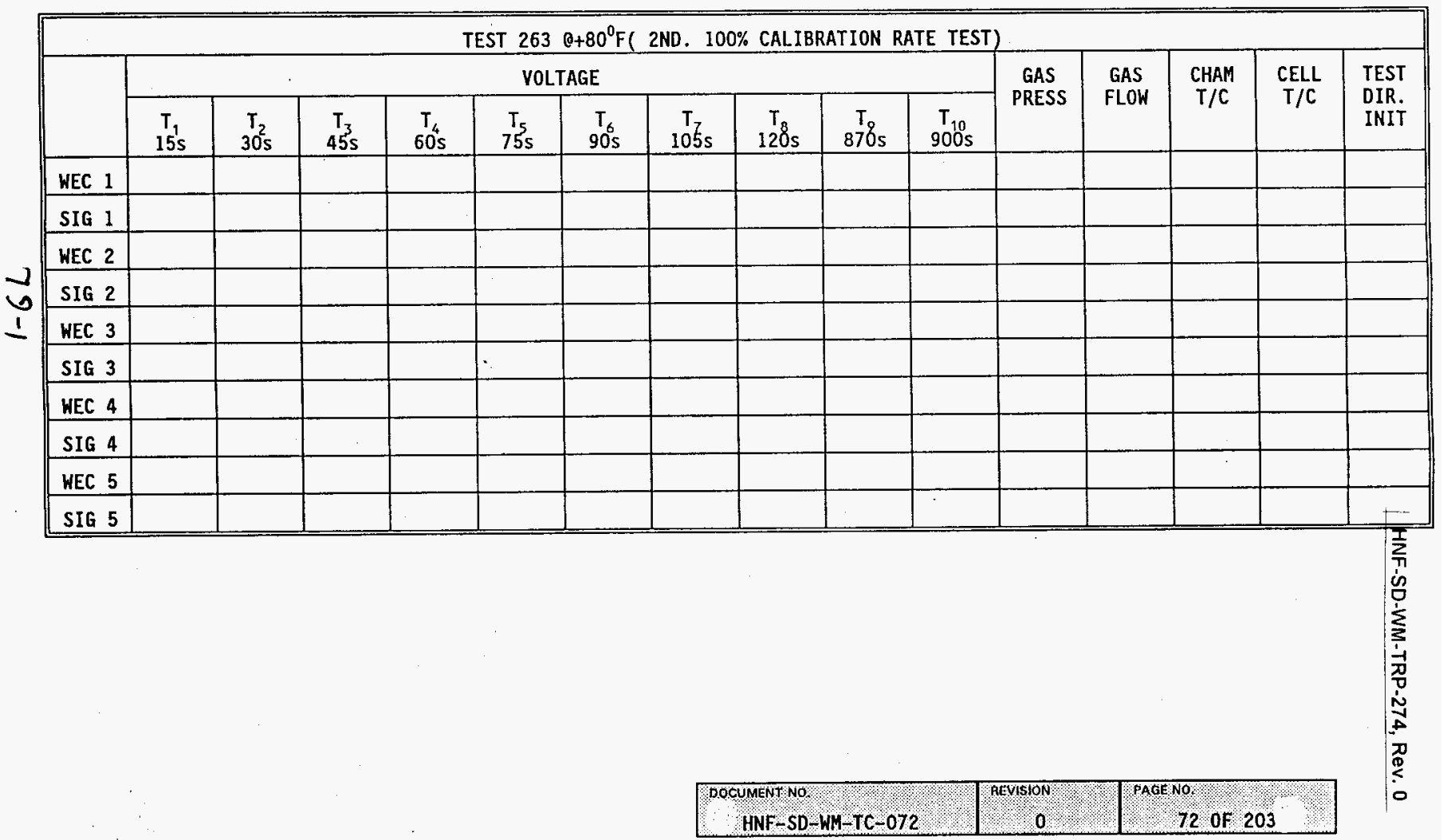


TEST PROCEDURE FOR MEASUREMENT OF PERFORMANCE VS TEMPERATURE WHITTAKER CELL

9.56 DATA RECORD SHEET 264

\begin{tabular}{|c|c|c|c|c|c|c|c|c|c|c|c|c|c|c|c|}
\hline \multicolumn{16}{|c|}{ TEST $264 @+80^{\circ} \mathrm{F}$ (3RD. $100 \%$ CALIBRATION RATE TEST) } \\
\hline & \multicolumn{10}{|c|}{ VOLTAGE } & \multirow{2}{*}{$\begin{array}{c}\text { GAS } \\
\text { PRESS }\end{array}$} & \multirow{2}{*}{$\begin{array}{l}\text { GAS } \\
\text { FLOW }\end{array}$} & \multirow{2}{*}{$\begin{array}{l}\text { CHAM } \\
T / C\end{array}$} & \multirow{2}{*}{$\begin{array}{c}\text { CELL } \\
\text { T/C }\end{array}$} & \multirow{2}{*}{$\begin{array}{l}\text { TEST } \\
\text { DIR. } \\
\text { INIT }\end{array}$} \\
\hline & $\begin{array}{c}\mathrm{T}_{1} \\
15 \mathrm{~s}\end{array}$ & $\begin{array}{c}T_{2} \\
30 s\end{array}$ & ${ }_{45 \mathrm{~s}}^{T_{3}}$ & $\begin{array}{c}T_{6} \\
60 \mathrm{~s}\end{array}$ & $\begin{array}{c}T_{5} \\
75 s\end{array}$ & $\begin{array}{l}T_{6} \\
905\end{array}$ & $\begin{array}{c}\mathrm{T} T \\
105 \mathrm{~s}\end{array}$ & $\begin{array}{c}T_{1} \\
120 \mathrm{~s}\end{array}$ & $\begin{array}{l}{ }^{\top} o_{\mathrm{s}} \\
870 \mathrm{~s}\end{array}$ & $\begin{array}{c}T_{10} \\
900 \mathrm{~s}\end{array}$ & & & & & \\
\hline \multicolumn{16}{|l|}{ WEC 1} \\
\hline SIG 1 & & & & & & & & & & & & & & & 폴 \\
\hline \multicolumn{16}{|l|}{ HEC 2} \\
\hline \multicolumn{16}{|l|}{ SIG 2} \\
\hline \multicolumn{16}{|l|}{ KEC 3} \\
\hline \multicolumn{16}{|l|}{ SIG 3} \\
\hline \multicolumn{16}{|l|}{ WEC 4} \\
\hline SIG 4 & & & & & & & & & & & & & & & 产 \\
\hline WEC 5 & & & & & & & & & & & & & & & 0 \\
\hline SIG 5 & & & & & & & & & & & & & & & \\
\hline
\end{tabular}

8
8 
TEST PROCEDURE FOR MEASUREMENT OF PERFORMANCE VS TEMPERATURE

WHITTAKER CELL

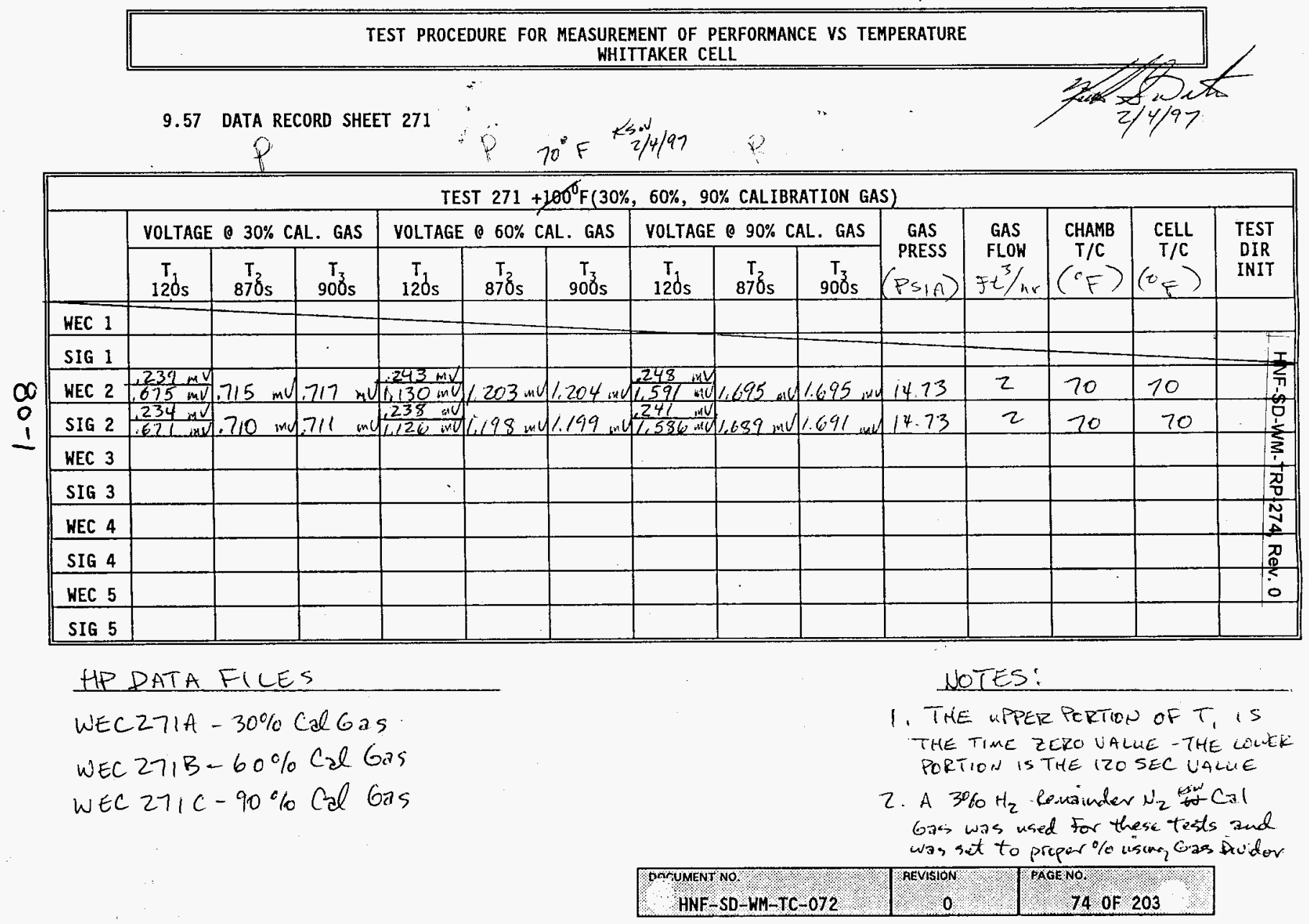


TEST PROCEDURE FOR MEASUREMENT OF PERFORMANCE VS TEMPERATURE WHITAKER CELL

9.58 DATA RECORD SHEET 272

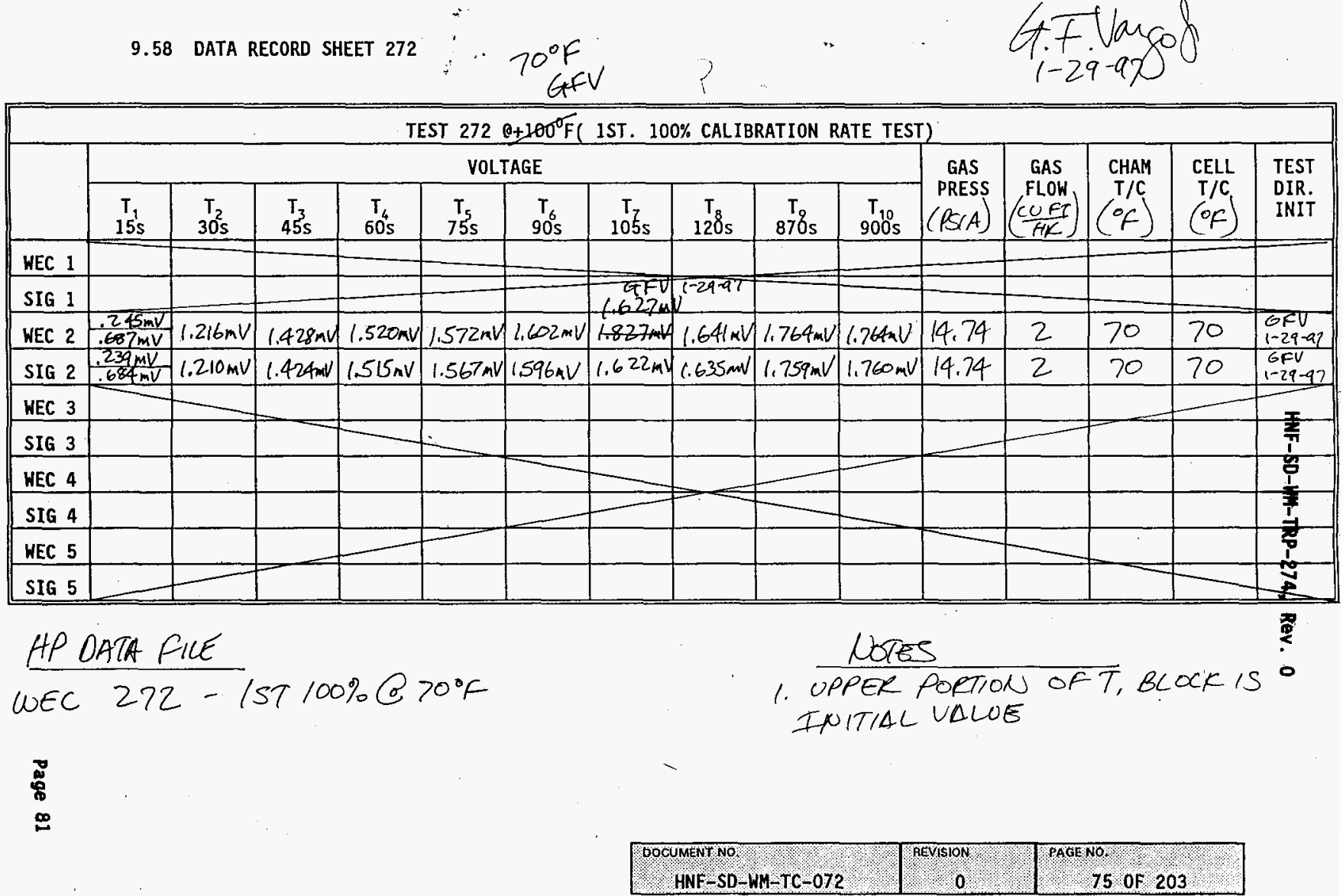


TEST PROCEDURE FOR MEASUREMENT OF PERFORMANCE VS TEMPERATURE

WHITTAKER CELL

\subsection{DATA RECORD SHEET 273}

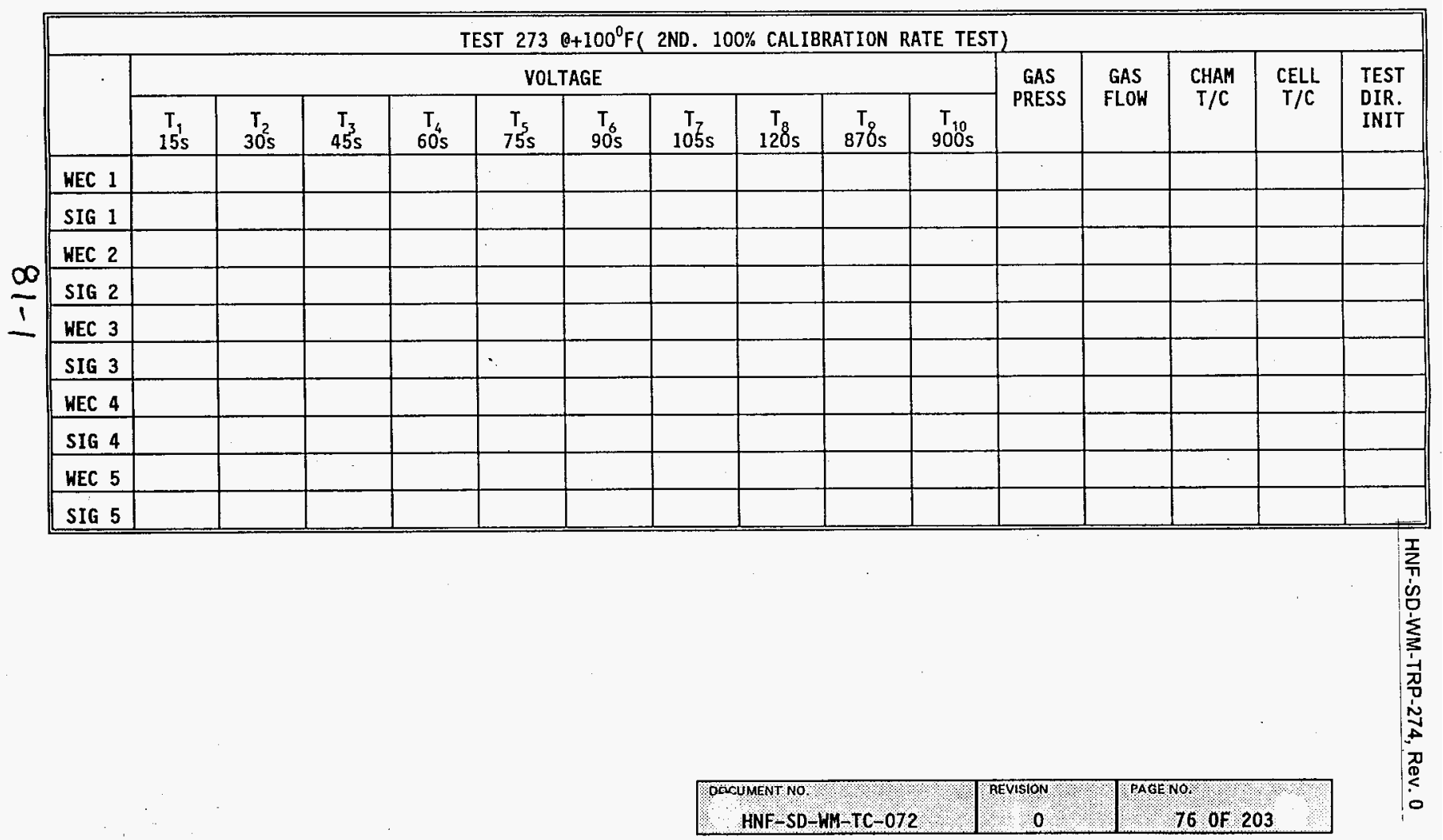


TEST PROCEDURE FOR MEASUREMENT OF PERFORMANCE VS TEMPERATURE

WHITTAKER CELL

9.60 DATA RECORD SHEET 274

TEST $2740+100^{\circ} \mathrm{F}$ (3RD. 100\% CALIBRATION RATE TEST)

\begin{tabular}{|c|c|c|c|c|c|c|c|c|c|c|c|c|c|c|c|}
\hline \multicolumn{16}{|c|}{ TEST $2740+100^{\circ} \mathrm{F}$ (3RD. $100 \%$ CALIBRATION RATE TEST) } \\
\hline & \multicolumn{10}{|c|}{ VOLTAGE } & \multirow{2}{*}{$\begin{array}{l}\text { GAS } \\
\text { PRESS }\end{array}$} & \multirow{2}{*}{$\begin{array}{l}\text { GAS } \\
\text { FLOW }\end{array}$} & \multirow{2}{*}{$\begin{array}{l}\text { CHAM } \\
\mathrm{T} / \mathrm{C}\end{array}$} & \multirow{2}{*}{$\begin{array}{c}\text { CELL } \\
T / C\end{array}$} & \multirow{2}{*}{$\begin{array}{l}\text { TEST } \\
\text { DIR. } \\
\text { INIT }\end{array}$} \\
\hline & $\begin{array}{r}T_{1}^{1} \\
15 s \\
\end{array}$ & $\begin{array}{r}\mathrm{T}_{2} \\
30 \mathrm{~s} \\
\end{array}$ & $\begin{array}{r}\mathrm{T}_{3}{ }^{3} \mathrm{~s} \\
45 \mathrm{~s}\end{array}$ & $\begin{array}{r}T_{4} \\
60{ }^{4} \\
\end{array}$ & $\begin{array}{r}T_{5} \\
755 \\
\end{array}$ & $\begin{array}{c}\mathrm{T}_{6} \\
90 \mathrm{~s}\end{array}$ & $\begin{array}{c}T^{T} z_{s} \\
105 s\end{array}$ & $\begin{array}{c}\mathrm{T}_{\mathrm{g}} \\
120 \mathrm{~s}\end{array}$ & $\begin{array}{c}T_{\mathrm{o}} \\
870 \mathrm{~s}\end{array}$ & $\begin{array}{c}T_{10} \\
900 s \\
\end{array}$ & & & & & \\
\hline \multicolumn{16}{|l|}{ WEC 1} \\
\hline SIG 1 & & & & & & & & & & & & & & & $\frac{7}{7}$ \\
\hline \multicolumn{16}{|l|}{ WEC 2} \\
\hline SIG 2 & & & & & & & & & & & & & & & $\frac{\bar{t}}{+\frac{1}{+}}$ \\
\hline WEC 3 & & & & & & & & & & & & & & & 齐 \\
\hline SIG 3 & & & & & & & & & & & & & & & $\underset{\pi}{\pi}$ \\
\hline \multicolumn{16}{|l|}{ HEC 4} \\
\hline SIG 4 & & & & & & & & & & & & & & & ? \\
\hline WEC 5 & & & & & & & & & & & & & & & 0 \\
\hline SIG 5 & & & & & & & & & & & & & & & \\
\hline
\end{tabular}

怘 
TEST PROCEDURE FOR MEASUREMENT OF PERFORMANCE VS TEMPERATURE

WHITTAKER CELL

\subsection{DATA RECORD SHEET $281 ;$}

TEST $281+120^{\circ} \mathrm{F}(30 \%, 60 \%, 90 \%$ CALIBRATION GAS $)$

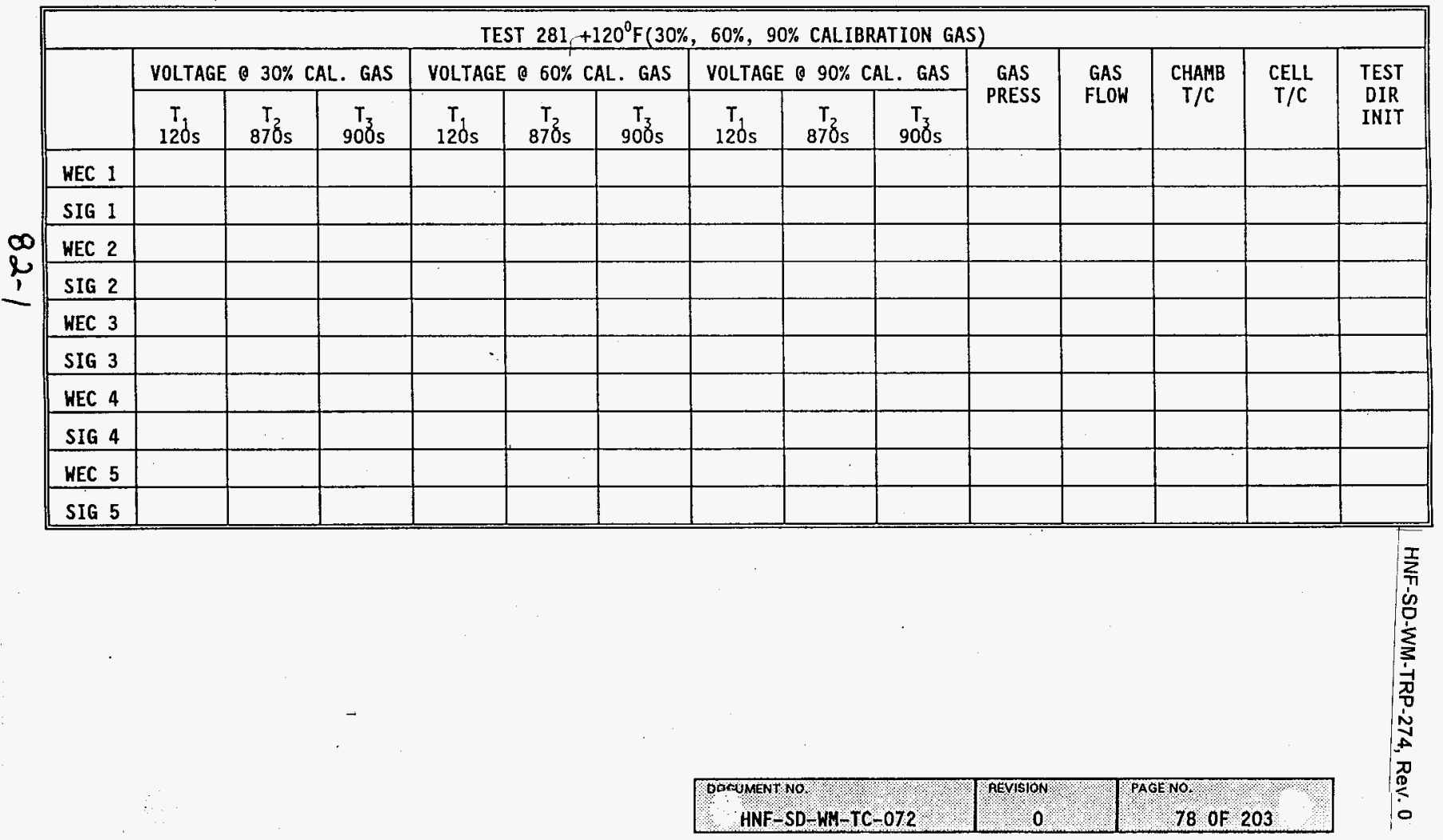


TEST PROCEDURE FOR MEASUREMENT OF PERFORMANCE VS TEMPERATURE WHITAKER CELL

9.62 DATA RECORD SHEET 282

$80^{\circ} \mathrm{F}$

$2 / 1 / 97$

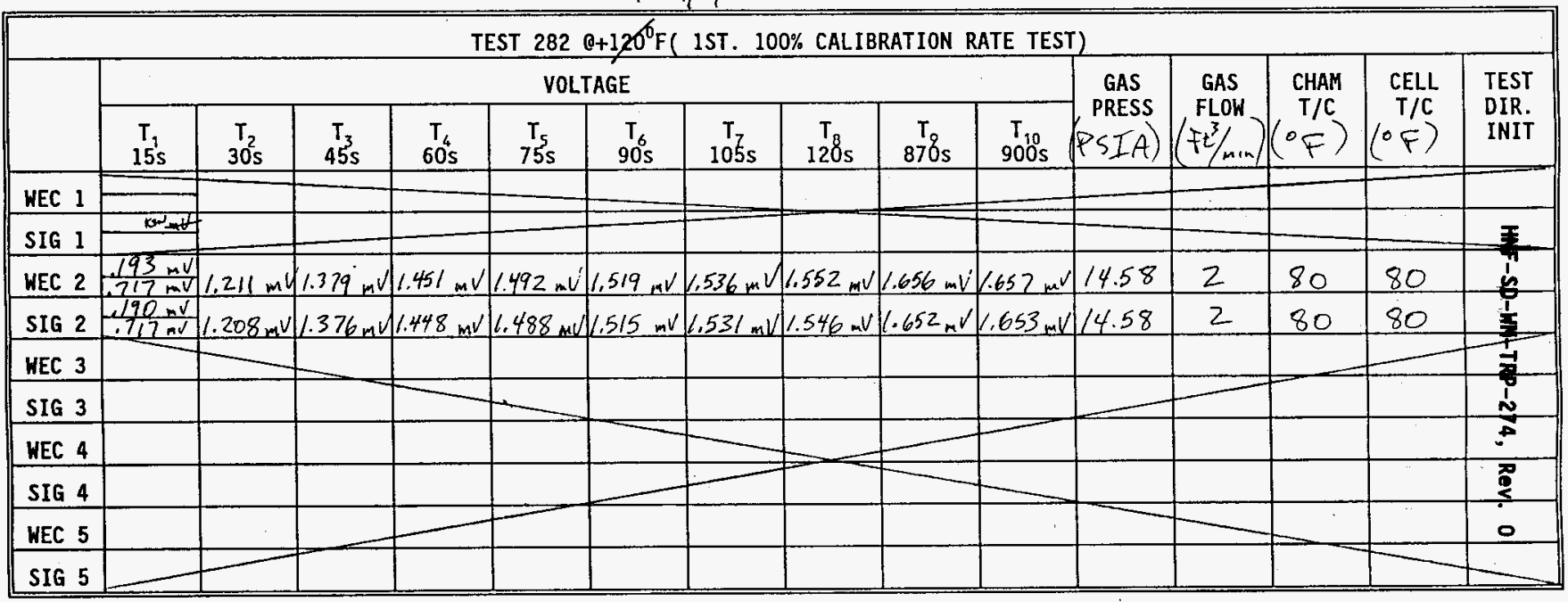

HP DATA FILE

WED $282-1^{5} \% 100 \% \propto 80^{\circ} \mathrm{F}$

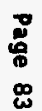

NOTES

1. UPPER PORTION OF $T_{1}$ BLOCK is initial value, lower portion is $15 \mathrm{sec}$ value.

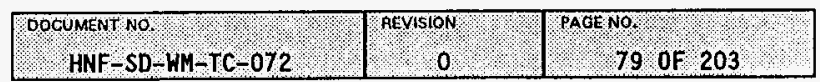


TEST PROCEDURE FOR MEASUREMENT OF PERFORMANCE VS TEMPERATURE

WHITTAKER CELL

\subsection{DATA RECORD SHEET 283}

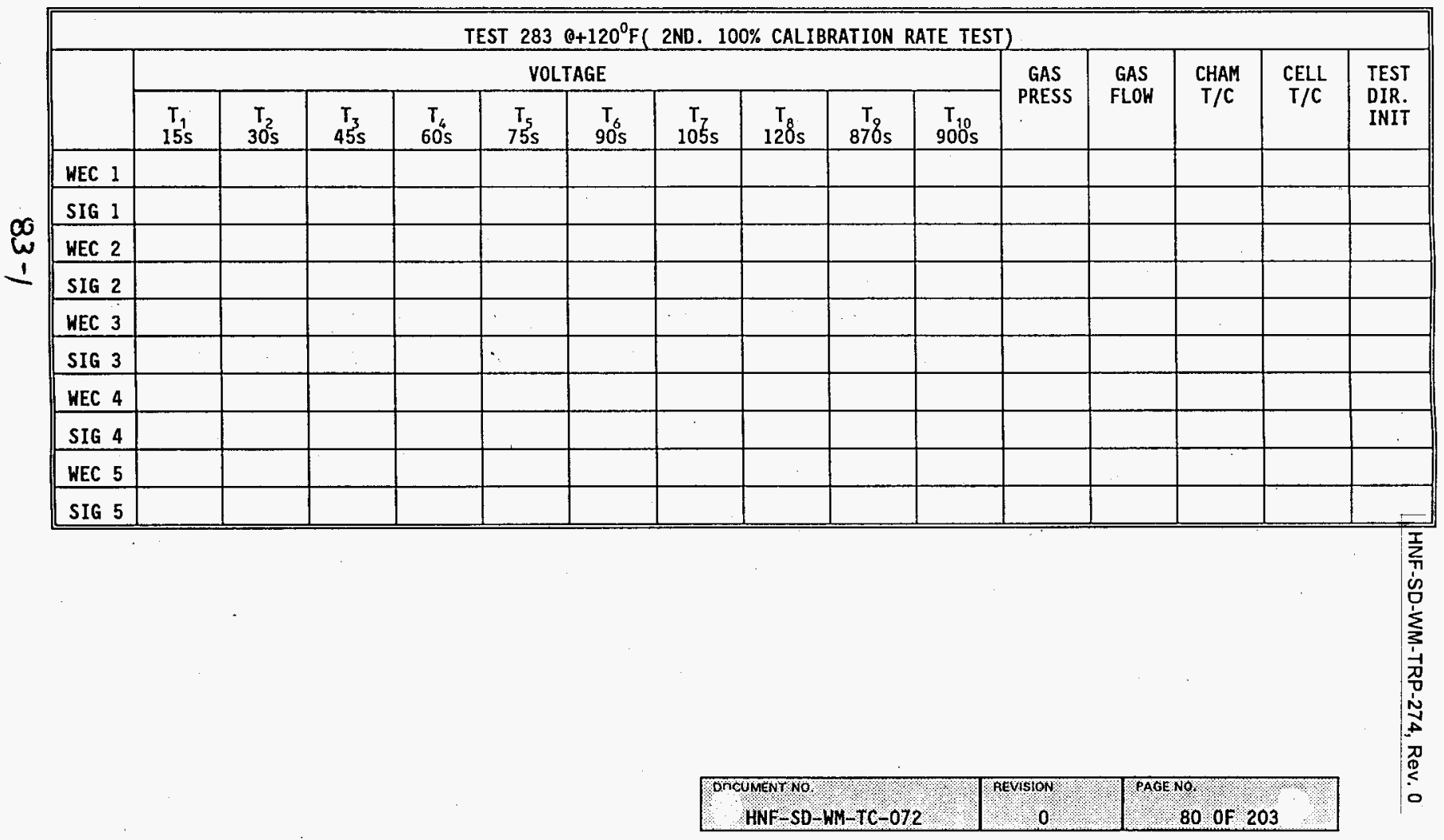


TEST PROCEDURE FOR MEASUREMENT OF PERFORMANCE VS TEMPERATURE

WHITTAKER CELL

\subsection{DATA RECORD SHEET 284}

\begin{tabular}{|c|c|c|c|c|c|c|c|c|c|c|c|c|c|c|c|}
\hline \multicolumn{16}{|c|}{ TEST $2840+120^{\circ} \mathrm{F}$ (3RD. $100 \%$ CALIBRATION RATE TEST) } \\
\hline & \multicolumn{10}{|c|}{ VOLTAGE } & \multirow{2}{*}{$\begin{array}{c}\text { GAS } \\
\text { PRESS }\end{array}$} & \multirow{2}{*}{$\begin{array}{l}\text { GAS } \\
\text { FLOW }\end{array}$} & \multirow{2}{*}{$\begin{array}{l}\text { CHAM } \\
T / C\end{array}$} & \multirow{2}{*}{$\begin{array}{l}\text { CELL } \\
T / C\end{array}$} & \multirow{2}{*}{$\begin{array}{l}\text { TEST } \\
\text { DIR. } \\
\text { INIT }\end{array}$} \\
\hline & $\begin{array}{c}T_{1} \\
15 s\end{array}$ & $\begin{array}{r}T_{2} \\
30 s \\
\end{array}$ & $\begin{array}{r}T_{3} \\
45 \mathrm{~s} \\
\end{array}$ & $\begin{array}{r}T_{4} \\
60 \mathrm{~s} \\
\end{array}$ & $\begin{array}{r}T_{5} \\
75 \mathrm{~s} \\
\end{array}$ & $\begin{array}{c}T_{6} \\
90 \mathrm{~s} \\
\end{array}$ & $\begin{array}{c}\mathrm{T}_{\mathrm{T}} \\
105 \mathrm{~s}\end{array}$ & $\begin{array}{c}T_{8} \\
120 \mathrm{~s} \\
\end{array}$ & $\begin{array}{r}\mathrm{T} \\
87 \% \mathrm{~s} \\
\end{array}$ & $\begin{array}{c}T_{10} \\
900 \mathrm{~s} \\
\end{array}$ & & & & & \\
\hline \multicolumn{16}{|l|}{ WEC 1} \\
\hline \multicolumn{16}{|l|}{ SIG 1} \\
\hline \multicolumn{16}{|l|}{ WEC 2} \\
\hline \multicolumn{16}{|l|}{ SIG 2} \\
\hline \multicolumn{16}{|l|}{ WEC 3} \\
\hline \multicolumn{16}{|l|}{ SIG 3} \\
\hline \multicolumn{16}{|l|}{ WEC 4} \\
\hline \multicolumn{16}{|l|}{ SIG 4} \\
\hline WEC 5 & & & & & & & & & & & & & & & 0 \\
\hline SIG 5 & & & & & & & & & & & & & & & \\
\hline
\end{tabular}

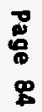


TEST PROCEDURE FOR MEASUREMENT OF PERFORMANCE VS TEMPERATURE WHITTAKER CELL

9.65 DATA RECORD SHEET 311

TEST $311-20^{\circ} \mathrm{F}(30 \%, 60 \%, 90 \%$ CALIBRATION GAS)

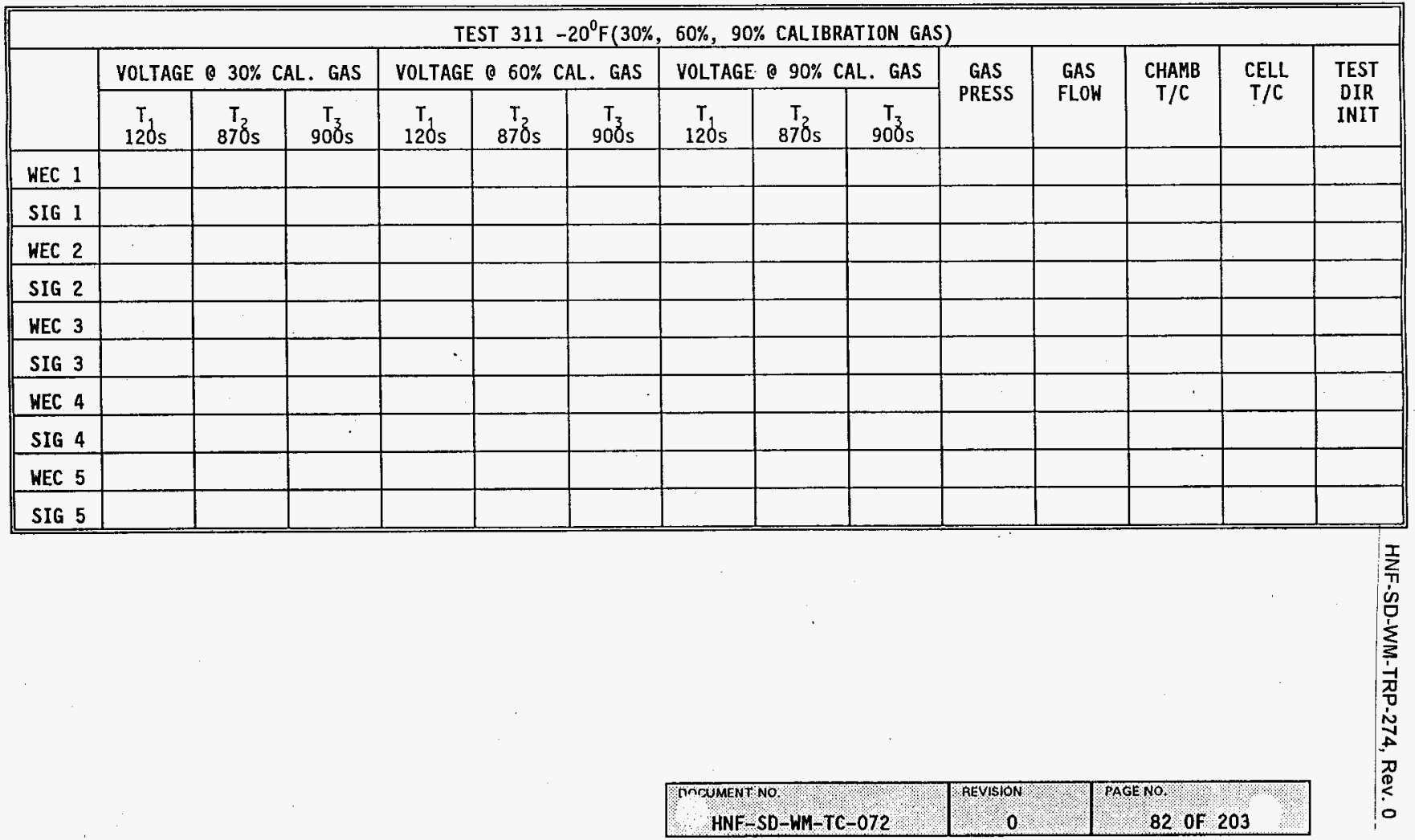


TEST PROCEDURE FOR MEASUREMENT OF PERFORMANCE VS TEMPERATURE

WHITTAKER CELL

\subsection{DATA RECORD SHEET 312}

\begin{tabular}{|c|c|c|c|c|c|c|c|c|c|c|c|c|c|c|c|}
\hline & \multicolumn{10}{|c|}{$\frac{\text { TEST } 3120-20^{\circ} \mathrm{F} \text { (1ST. 100\% CALIBRATION RATE TEST }}{\text { VOLTAGE }}$} & \multirow{2}{*}{$\begin{array}{l}\text { GAS } \\
\text { PRESS }\end{array}$} & \multirow{2}{*}{$\begin{array}{l}\text { GAS } \\
\text { FLOW }\end{array}$} & \multirow{2}{*}{$\underset{\mathrm{T} / \mathrm{C}}{\mathrm{CHAM}}$} & \multirow{2}{*}{$\begin{array}{l}\text { CELL } \\
T / C\end{array}$} & \multirow{2}{*}{$\begin{array}{l}\text { TEST } \\
\text { DIR. } \\
\text { INIT }\end{array}$} \\
\hline & $\begin{array}{c}T_{1} \\
15 \mathrm{~s}\end{array}$ & $\begin{array}{c}\mathrm{T}_{2} \\
30 \mathrm{~s}\end{array}$ & $\begin{array}{r}T_{3} \\
{ }_{45} \mathrm{~s}\end{array}$ & $\begin{array}{r}\mathrm{T}_{4} \\
60 \mathrm{~s} \\
\end{array}$ & $\begin{array}{r}T_{5} \\
75 \mathrm{~s} \\
\end{array}$ & $\begin{array}{c}T_{6} \\
90 \mathrm{~s}\end{array}$ & $\begin{array}{c}{ }^{T} Z_{s} \\
105 s\end{array}$ & $\begin{array}{c}\mathrm{T} \\
12 \delta_{\mathrm{s}}\end{array}$ & $\begin{array}{c}T^{\top} \delta_{\mathrm{s}} \\
870 \mathrm{~s}\end{array}$ & $\begin{array}{c}T_{10} \\
900 \mathrm{~s}\end{array}$ & & & & & \\
\hline \multicolumn{16}{|l|}{ WEC 1} \\
\hline \multicolumn{16}{|l|}{ SIG I } \\
\hline \multicolumn{16}{|l|}{ WEC 2} \\
\hline \multicolumn{16}{|l|}{ SIG 2} \\
\hline \multicolumn{16}{|l|}{ WEC 3} \\
\hline SIG 3 & & & & & & & & & & & & & & & $\mathbb{T}$ \\
\hline \multicolumn{16}{|l|}{ MEC 4} \\
\hline \multicolumn{16}{|l|}{ SIG 4} \\
\hline \multicolumn{16}{|l|}{ HEC 5} \\
\hline SIG 5 & & & & & & & & & & & & & & & \\
\hline
\end{tabular}

D
审
o 
TEST PROCEDURE FOR MEASUREMENT OF PERFORMANCE VS TEMPERATURE WHITTAKER CELL

\subsection{DATA RECORD SHEET 313}

TEST $3130-20^{\circ} \mathrm{F}$ ( 2ND. $100 \%$ CALIBRATION RATE TEST)

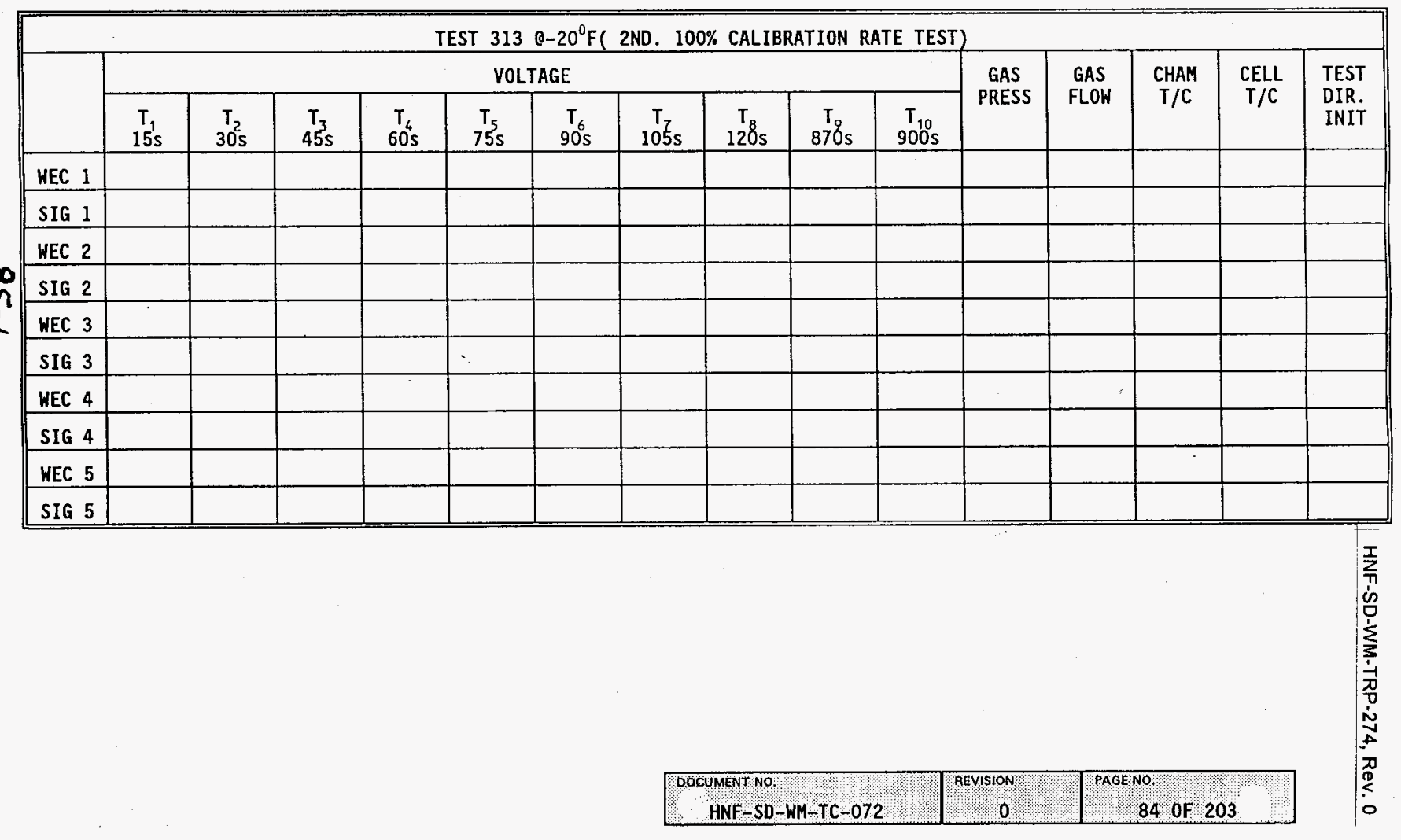


TEST PROCEDURE FOR MEASUREMENT OF PERFORMANCE VS TEMPERATURE WHITTAKER CELL

\subsection{DATA RECORD SHEET 314}

TEST $3140-20^{\circ} \mathrm{F}$ ( 3RD. 100\% CALIBRATION RATE TEST)

\begin{tabular}{|c|c|c|c|c|c|c|c|c|c|c|c|c|c|c|c|}
\hline & \multicolumn{10}{|c|}{ VOLTAGE } & \multirow{2}{*}{$\begin{array}{c}\text { GAS } \\
\text { PRESS }\end{array}$} & \multirow{2}{*}{$\begin{array}{l}\text { GAS } \\
\text { FLOW }\end{array}$} & \multirow{2}{*}{$\begin{array}{c}\text { CHAM } \\
\mathrm{T} / \mathrm{C}\end{array}$} & \multirow{2}{*}{$\begin{array}{c}\text { CELL } \\
T / C\end{array}$} & \multirow{2}{*}{$\begin{array}{l}\text { TEST } \\
\text { DIR. } \\
\text { INIT }\end{array}$} \\
\hline & $\begin{array}{r}T_{1} \\
15 \mathrm{~s} \\
\end{array}$ & $\begin{array}{r}\mathrm{T}_{2} \\
30 \mathrm{~s} \\
\end{array}$ & $\begin{array}{r}T_{3} \\
45 \mathrm{~s} \\
\end{array}$ & $\begin{array}{r}T_{4} \\
60 \mathrm{~s} \\
\end{array}$ & $\begin{array}{r}T_{5} \\
75 \mathrm{~s} \\
\end{array}$ & $\begin{array}{r}\mathrm{T}_{6} \\
90 \mathrm{~s} \\
\end{array}$ & $\begin{array}{c}T_{7} \\
105 s\end{array}$ & $\begin{array}{r}T_{8} \\
120 \mathrm{~s} \\
\end{array}$ & $\begin{array}{c}\mathrm{T}_{8} \\
870 \mathrm{~s}\end{array}$ & $\begin{array}{r}T_{10} \\
900 \mathrm{~s} \\
\end{array}$ & & & & & \\
\hline \multicolumn{16}{|l|}{ WEC 1} \\
\hline \multicolumn{16}{|l|}{ SIG 1} \\
\hline \multicolumn{16}{|l|}{ WEC 2} \\
\hline \multicolumn{16}{|l|}{ SIG 2} \\
\hline \multicolumn{16}{|l|}{ WEC 3} \\
\hline \multicolumn{16}{|l|}{ SIG 3} \\
\hline \multicolumn{16}{|l|}{ NEC 4} \\
\hline SIG 4 & & & & & & & & & & & & & & & 蛋 \\
\hline WEC 5 & & & & & & & & & & & & & & & 0 \\
\hline SIG 5 & & & & & & & & & & & & & & & \\
\hline
\end{tabular}

8

\begin{tabular}{|c|c|c|}
\hline DOCUMENT NO & AEVISION & PAGENO \\
\hline HNF-SD-WM-TC-072 & 0 & 85 or 203 \\
\hline
\end{tabular}




\subsection{DATA RECORD SHEET 321}

TEST $3210^{\circ} \mathrm{F}(30 \%, 60 \%, 90 \%$ CALIBRATION GAS $)$

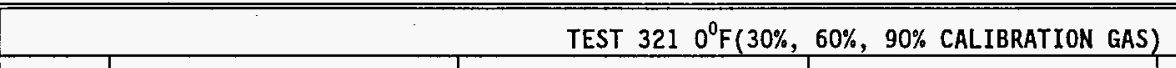

\begin{tabular}{|c|c|c|c|c|c|c|c|c|c|c|c|c|c|c|}
\hline & \multicolumn{3}{|c|}{ VOLTAGE \& $30 \%$ CAL. GAS } & \multicolumn{3}{|c|}{ VOLTAGE \& $60 \%$ CAL. GAS } & \multicolumn{3}{|c|}{ VOLTAGE @ $90 \%$ CAL. GAS } & \multirow{2}{*}{$\begin{array}{c}\text { GAS } \\
\text { PRESS }\end{array}$} & \multirow{2}{*}{$\begin{array}{l}\text { GAS } \\
\text { FLOW }\end{array}$} & \multirow{2}{*}{$\underset{\mathrm{T} / \mathrm{C}}{\text { CHAMB }}$} & \multirow{2}{*}{$\begin{array}{c}\text { CELL } \\
T / C\end{array}$} & \multirow{2}{*}{$\begin{array}{c}\text { TEST } \\
\text { DIR } \\
\text { INIT }\end{array}$} \\
\hline & $\begin{array}{c}T_{1} \\
120 \mathrm{~s}\end{array}$ & $\begin{array}{c}T_{2} \\
870 \mathrm{~s}\end{array}$ & ${ }_{900 \mathrm{~s}}^{\mathrm{T}_{3}}$ & $\begin{array}{c}\mathrm{T}_{1} \\
120 \mathrm{~s}\end{array}$ & $\begin{array}{c}T_{2} \\
870 \mathrm{~s}\end{array}$ & $\begin{array}{c}\mathrm{T}_{3} \\
900 \mathrm{~s}\end{array}$ & $\begin{array}{c}\mathrm{T}_{\mathrm{d}} \\
120 \mathrm{~s} \\
\end{array}$ & $\begin{array}{c}\mathrm{T}_{2} \\
870 \mathrm{~s} \\
\end{array}$ & $\begin{array}{c}T_{3} \\
900 s\end{array}$ & & & & & \\
\hline \multicolumn{15}{|l|}{ WEC 1} \\
\hline \multicolumn{15}{|l|}{ SIG I } \\
\hline \multicolumn{15}{|l|}{ WEC 2} \\
\hline \multicolumn{15}{|l|}{ SIG 2} \\
\hline \multicolumn{15}{|l|}{ WEC 3} \\
\hline \multicolumn{15}{|l|}{ SIG 3} \\
\hline \multicolumn{15}{|l|}{ WEC 4} \\
\hline \multicolumn{15}{|l|}{ SIG 4} \\
\hline \multicolumn{15}{|l|}{ HEC 5} \\
\hline SIG 5 & & & & & & & & & & & & & & \\
\hline
\end{tabular}




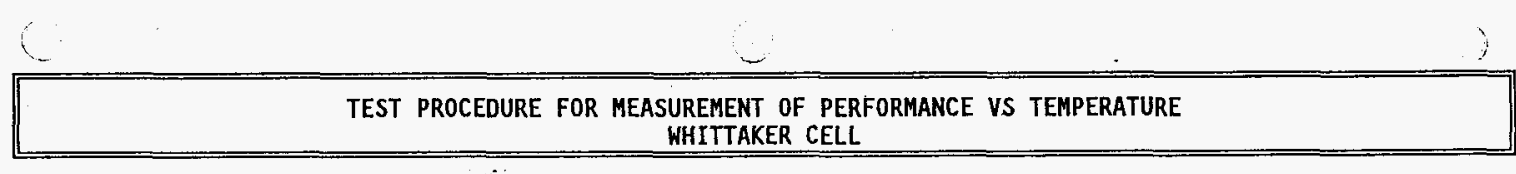

9.70 DATA RECORD SHEET 322

\begin{tabular}{||c|c|c|c|c|c|c|c|c|c|c|c|c|c|c|c||}
\hline \multicolumn{10}{||c|}{ TEST 322 $00^{\circ} \mathrm{F}$ ( 1 15T. 100\% CAL IBRATION RATE TEST) } \\
\hline
\end{tabular}

8
8
8 
TEST PROCEDURE FOR MEASUREMENT OF PERFORMANCE VS TEMPERATURE

WHITTAKER CELL

9.71 DATA RECORD SHEET 323

TEST $32300^{\circ} \mathrm{F}$ ( 2ND. 100\% CALIBRATION RATE TEST)

\section{VOLTAGE}

\begin{tabular}{|c|c|c|c|c|c|c|c|c|c|c|c|}
\hline & \multicolumn{10}{|c|}{ VOLTAGE } & \multirow{2}{*}{$\begin{array}{c}\text { GAS } \\
\text { PRESS }\end{array}$} \\
\hline & $\begin{array}{c}T_{1} \\
15 \mathrm{~s} \\
\end{array}$ & $\begin{array}{r}\mathrm{T}_{2} \\
300 \mathrm{~s} \\
\end{array}$ & $\begin{array}{r}T_{3} \\
45 \mathrm{~s} \\
\end{array}$ & $\begin{array}{r}T_{4} \\
600 \mathrm{~s} \\
\end{array}$ & $\begin{array}{r}T_{5} \\
75 \mathrm{~s} \\
\end{array}$ & $\begin{array}{r}\mathrm{T}_{6} \\
900 \mathrm{~s} \\
\end{array}$ & $\begin{array}{c}\mathrm{T}_{7} \\
105 \mathrm{~s} \\
\end{array}$ & $\begin{array}{r}\mathrm{T}_{8} \\
120 \mathrm{~s} \\
\end{array}$ & $\begin{array}{c}\mathrm{T} / \mathrm{s} \\
870 \mathrm{~s}\end{array}$ & $\begin{array}{c}\mathrm{T}_{10} \\
900 \mathrm{~s}\end{array}$ & \\
\hline \multicolumn{12}{|l|}{ WEC 1} \\
\hline SIG 1 & & & & & & & & & & & \\
\hline WEC 2 & & & & & & & & & & & \\
\hline SIG 2 & & & & & & & & & & & \\
\hline WEC 3 & & & & & & & & & & & \\
\hline SIG 3 & & & & & & & & & & & \\
\hline HEC 4 & & & & & & & & & & & \\
\hline SIG 4 & & & & & & & & & & & \\
\hline WEC 5 & & & & & & & & & & & \\
\hline SIG 5 & & & & & & & & & & & \\
\hline
\end{tabular}




\subsection{DATA RECORD SHEET 324}

\begin{tabular}{|c|c|c|c|c|c|c|c|c|c|c|c|c|c|c|c|}
\hline \multicolumn{16}{|c|}{ TEST $3240^{\circ} 0^{\circ} \mathrm{F}$ (3RD. $100 \%$ CALIBRATION RATE TEST) } \\
\hline & \multicolumn{10}{|c|}{ VOLTAGE } & \multirow{2}{*}{$\begin{array}{l}\text { GAS } \\
\text { PRESS }\end{array}$} & \multirow{2}{*}{$\begin{array}{l}\text { GAS } \\
\text { FLOW }\end{array}$} & \multirow{2}{*}{$\begin{array}{l}\text { CHAM } \\
\mathrm{T} / \mathrm{C}\end{array}$} & \multirow{2}{*}{$\begin{array}{l}\text { CELL } \\
\mathbf{T} / \mathbf{C}\end{array}$} & \multirow{2}{*}{$\begin{array}{l}\text { TEST } \\
\text { oIR. } \\
\text { INI }\end{array}$} \\
\hline & $\begin{array}{r}T_{1} \\
15 s\end{array}$ & $\begin{array}{c}T_{2} \\
30 \mathrm{~S}\end{array}$ & $\begin{array}{r}T_{3} \\
45 s \\
\end{array}$ & $\begin{array}{r}T_{4} \\
60 \mathrm{~s}\end{array}$ & $\begin{array}{l}T_{5} \\
75_{5}\end{array}$ & $\begin{array}{c}\mathrm{T}_{6} \\
90 \mathrm{~S}\end{array}$ & $\begin{array}{c}\mathrm{T}_{2} \\
{ }_{105 \mathrm{~s}}\end{array}$ & $\begin{array}{c}\mathrm{T}_{8} \\
120 \mathrm{~s}\end{array}$ & $\begin{array}{c}{ }^{\top} \mathrm{s}_{\mathrm{s}} \\
87 \mathrm{os}^{2}\end{array}$ & $\begin{array}{l}T_{10} \\
900 \mathrm{~s}\end{array}$ & & & & & \\
\hline \multicolumn{16}{|l|}{ WEC 1} \\
\hline \multicolumn{16}{|l|}{ SIG 1} \\
\hline \multicolumn{16}{|l|}{ WEC 2} \\
\hline \multicolumn{16}{|l|}{ SIG 2} \\
\hline \multicolumn{16}{|l|}{ HEC 3} \\
\hline \multicolumn{16}{|l|}{ SIG 3} \\
\hline WEC 4 & & & & & & & & & & & & & & & 圣 \\
\hline \multicolumn{16}{|l|}{ SIG 4} \\
\hline \multicolumn{16}{|l|}{ WEC 5} \\
\hline SIG 5 & & & & & & & & & & & & & & & \\
\hline
\end{tabular}

8
0
0

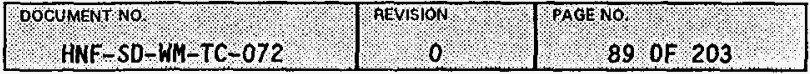


TEST PROCEDURE FOR MEASUREMENT OF PERFORMANCE VS TEMPERATURE WHITTAKER CELL

9.73 DATA RECORD SHEET 331

TEST $331+20^{\circ} \mathrm{F}(30 \%, 60 \%, 90 \%$ CALIBRATION GAS)

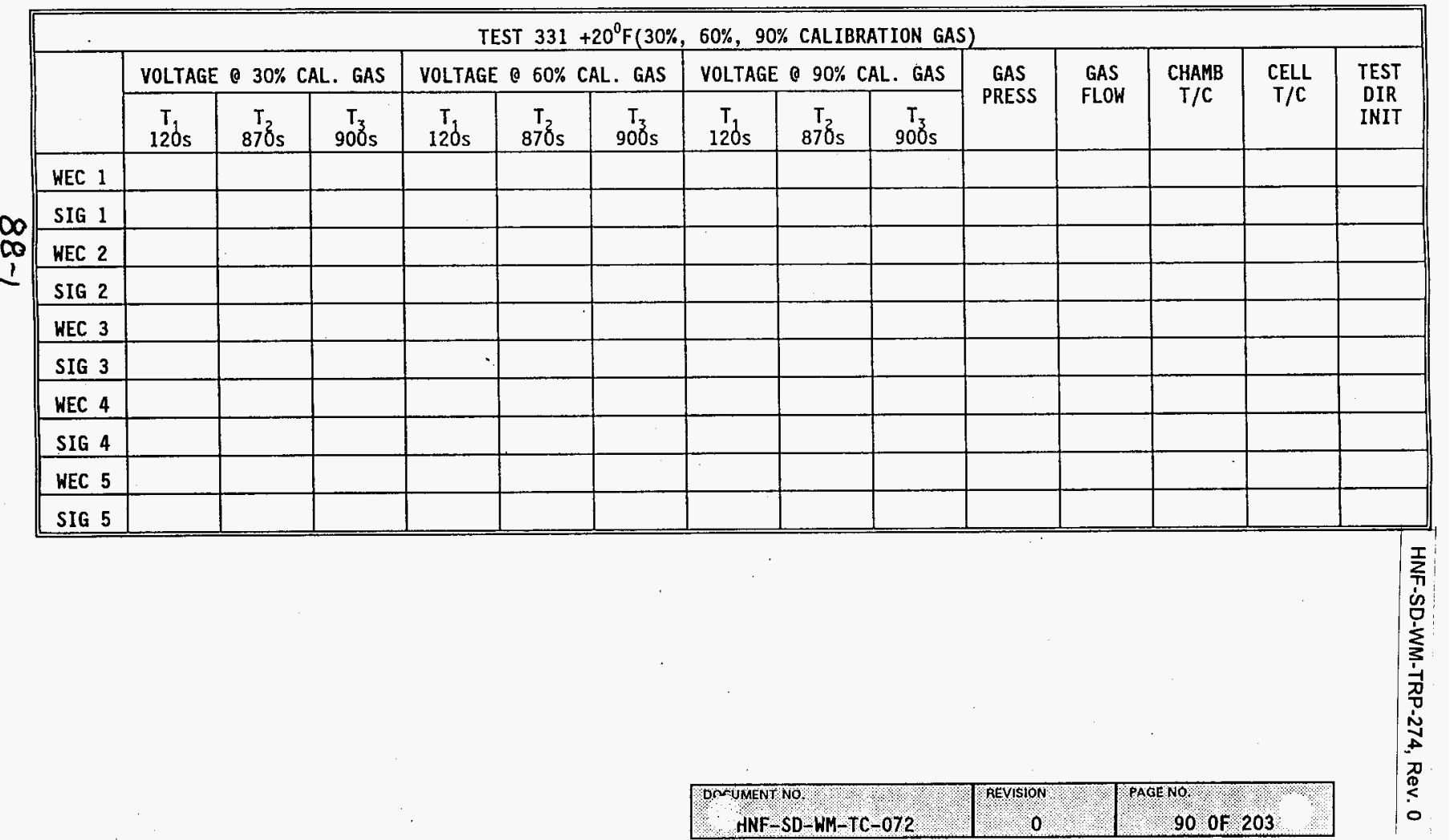


TEST PROCEDURE FOR MEASUREMENT OF PERFORMANCE VS TEMPERATURE WHITTAKER CELL

9.74 DATA RECORD SHEET 332

\begin{tabular}{|c|c|c|c|c|c|c|c|c|c|c|c|c|c|c|c|}
\hline \multicolumn{16}{|c|}{ TEST $332 \Theta+20^{\circ} \mathrm{F}(1 \mathrm{ST} . \quad 100 \%$ CALIBRATION RATE TEST) } \\
\hline & \multicolumn{10}{|c|}{ VOLTAGE } & \multirow{2}{*}{$\begin{array}{c}\text { GAS } \\
\text { PRESS }\end{array}$} & \multirow{2}{*}{$\begin{array}{l}\text { GAS } \\
\text { FLOW }\end{array}$} & \multirow{2}{*}{$\begin{array}{l}\text { CHAM } \\
T / C\end{array}$} & \multirow{2}{*}{$\begin{array}{l}\text { CELL } \\
T / C\end{array}$} & \multirow{2}{*}{$\begin{array}{l}\text { TEST } \\
\text { DIR } \\
\text { INIT }\end{array}$} \\
\hline & $\begin{array}{r}T_{1}^{1} \\
{ }_{1}^{15} \mathrm{~s}\end{array}$ & $\begin{array}{r}\mathrm{T}_{2} \\
30 \mathrm{~s} \\
\end{array}$ & $\begin{array}{r}\mathrm{T}_{3} \\
45 \mathrm{~s} \\
\end{array}$ & $\begin{array}{c}T_{4} \\
600^{2}\end{array}$ & $\begin{array}{r}T_{5}^{5} \\
75 s^{2}\end{array}$ & $\begin{array}{r}T_{6} \\
90 \mathrm{~s} \\
\end{array}$ & $\begin{array}{c}T^{T} \\
105 s\end{array}$ & $\begin{array}{c}\mathrm{T}_{8} \mathrm{~S}_{1} \\
\end{array}$ & $\begin{array}{c}\mathrm{T}_{\mathrm{T}} \\
870 \mathrm{~s}\end{array}$ & $\begin{array}{c}T_{10} \\
900 \mathrm{~s}\end{array}$ & & & & & \\
\hline WEC 1 & & & & & & & & & & & & & & & \\
\hline SIG I & & & & & & & & & & & & & & & $\frac{2}{7}$ \\
\hline WEC 2 & & & & & & & & & & & & & & & \% \\
\hline SIG 2 & & & & & & & & & & & & & & & 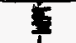 \\
\hline WEC 3 & & & & & & & & & & & & & & & 중 \\
\hline SIG 3 & & & & & & & & & & & & & & & $\underline{\sim}$ \\
\hline NEC 4 & & & & & & & & & & & & & & & 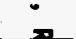 \\
\hline SIG 4 & & & & & & & & & & & & & & & $?$ \\
\hline HEC 5 & & & & & & & & & & & & & & & o \\
\hline SIG 5 & & & & & & & & & & & & & & & \\
\hline
\end{tabular}

品 


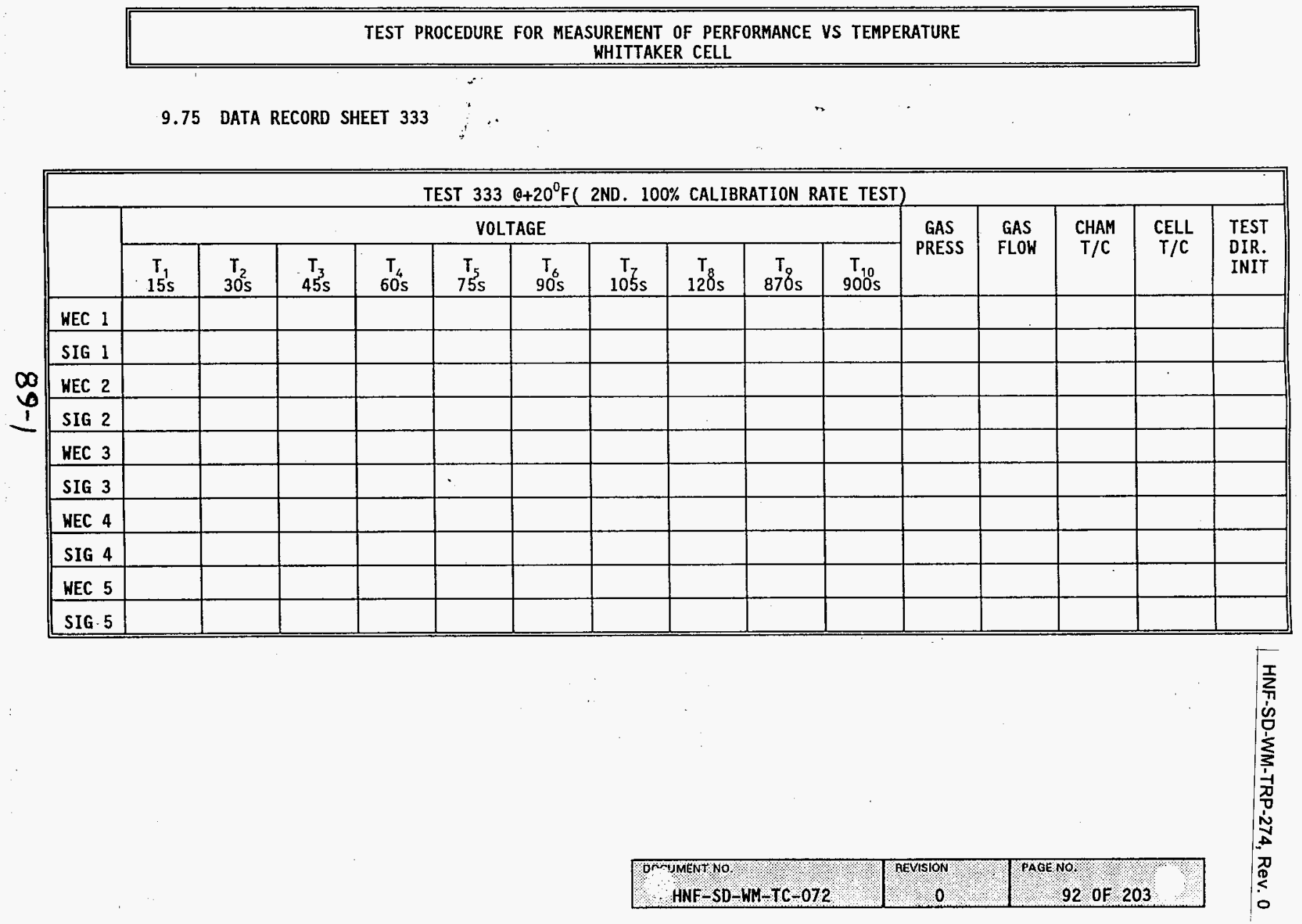




\begin{tabular}{|c|c|c|c|c|c|c|c|c|c|c|c|c|c|c|c|}
\hline & & & & & & & & & & & & & & & S 9IS \\
\hline & & & & & & & & & & & & & & & 9 J 34 \\
\hline 0 & & & & & & & & & & & & & & & 8 9IS \\
\hline $\overrightarrow{\widetilde{\alpha}}$ & & & & & & & & & & & & & & & $\square$ ग \\
\hline I & & & & & & & & & & & & & & & $\begin{array}{l}\varepsilon \text { IIS } \\
\end{array}$ \\
\hline$\frac{1}{2}$ & & & & & & & & & & & & & & & $\varepsilon \mathrm{J} \mathrm{JM}$ \\
\hline$\frac{-\frac{1}{2}}{\frac{1}{3}}$ & & & & & & & & & & & & & & & $\frac{2 \mathrm{gIS}}{2 \mathrm{TSH}}$ \\
\hline$\frac{1}{4}$ & & & & & & & & & & & & & & & I IIS \\
\hline 7 & & & & & & & & & & & & & & & I J3K \\
\hline \multirow{2}{*}{ 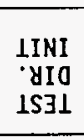 } & \multirow[b]{2}{*}{ כ/1 } & \multirow[b]{2}{*}{$\stackrel{3 / 1}{\text { WHH }}$} & \multirow[b]{2}{*}{$\begin{array}{l}\text { MO7f } \\
\text { S\$Y }\end{array}$} & \multirow{2}{*}{$\begin{array}{c}\text { SS SYYd } \\
\text { SYg }\end{array}$} & $\begin{array}{l}\text { sook } \\
0.10_{1}\end{array}$ & $s_{1} \angle 8$ & $\begin{array}{l}\text { sozI } \\
y_{1}\end{array}$ & sçol & $\begin{array}{l}\text { Sor } \\
\text { s.t. }\end{array}$ & $\begin{array}{l}\text { sgle } \\
s_{1}\end{array}$ & $\begin{array}{l}509 \\
1,1\end{array}$ & $\begin{array}{l}\text { sgt } \\
\varepsilon_{1}\end{array}$ & $\begin{array}{l}s_{0, \varepsilon} \\
?_{1}\end{array}$ & $\begin{array}{l}\text { SSGI } \\
S_{1}\end{array}$ & \\
\hline & & & & & \multicolumn{10}{|c|}{3981701} & \\
\hline
\end{tabular}




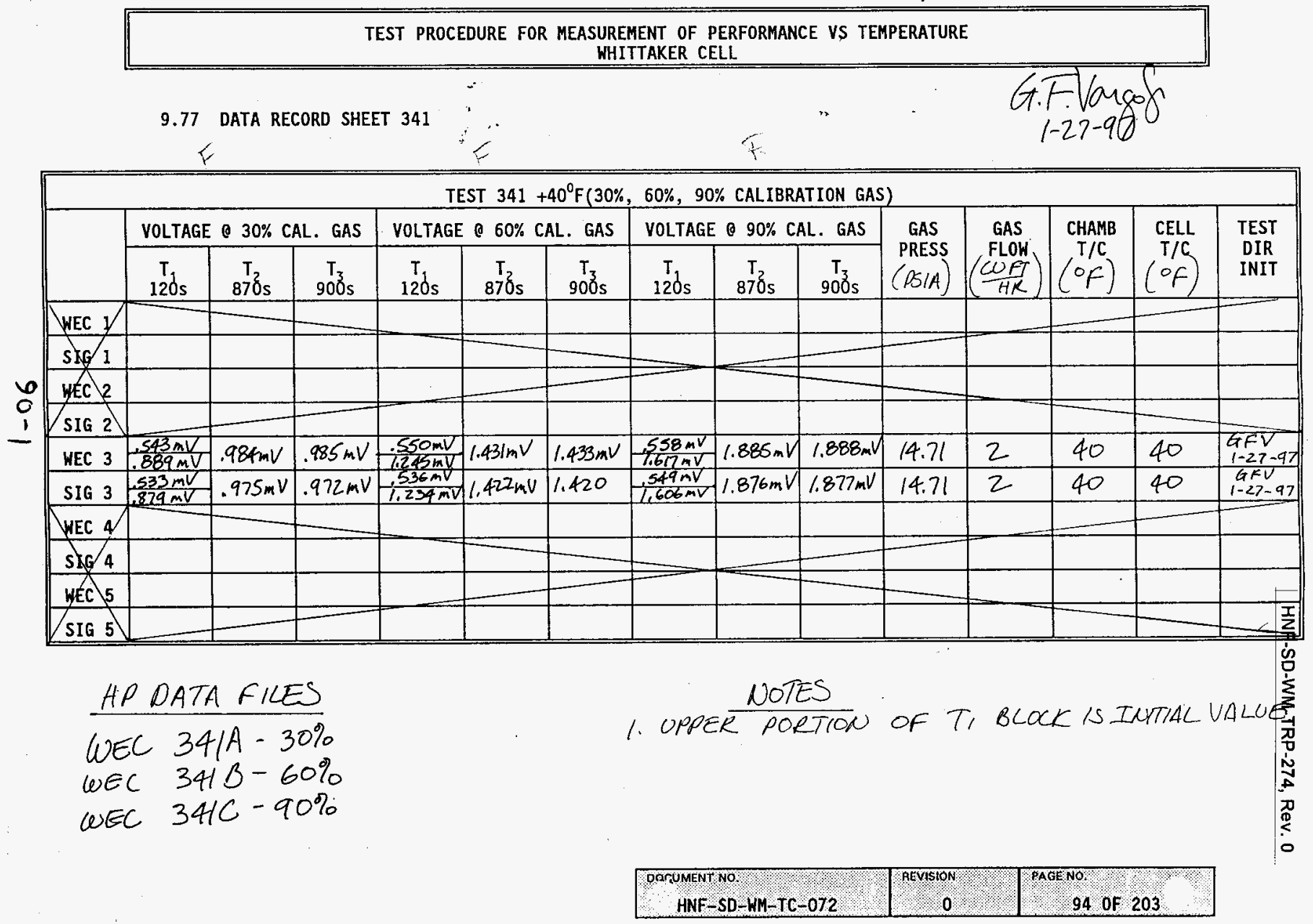


TEST PROCEDURE FOR MEASUREMENT OF PERFORMANCE VS TEMPERATURE

WHITTAKER CELL

\subsection{DATA RECORD SHEET 342}

$\div$

WhITAK

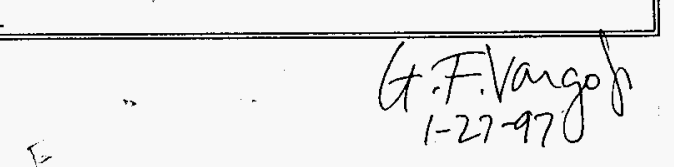

TEST $3420+40^{\circ} \mathrm{F}$ ( $15 T$. $100 \%$ CALIBRATION RATE TEST)

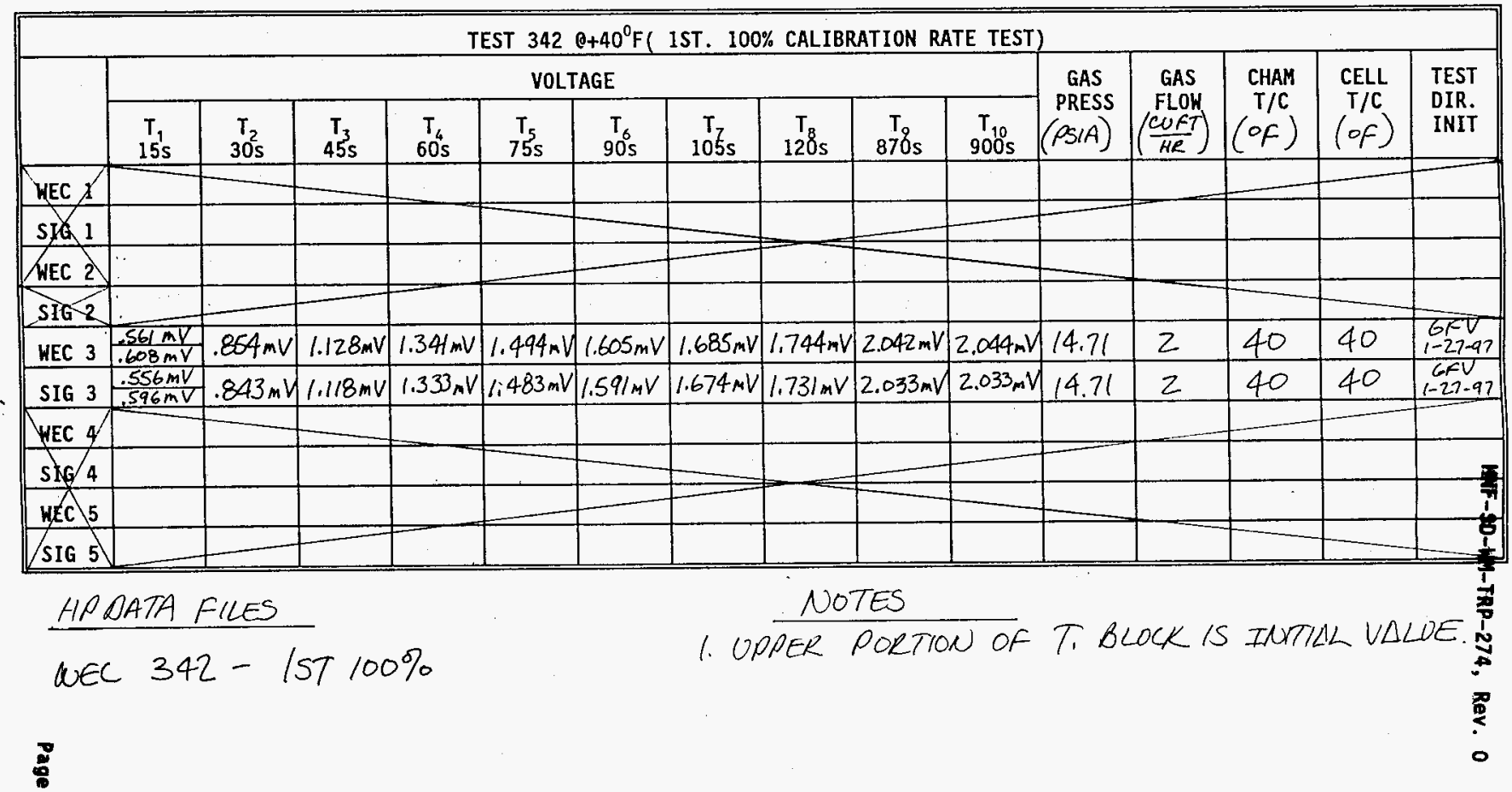

\begin{tabular}{|c|c|c|}
\hline DOCOMENTINO & AEVISION & PAGENO \\
\hline HNF-SD-WM-TC-072 & 0 & 95 of 203 \\
\hline
\end{tabular}

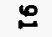


TEST PROCEDURE FOR MEASUREMENT OF PERFORMANCE VS TEMPERATURE

WHITTAKER CELL

\subsection{DATA RECORD SHEET 343}

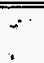

G.F.Vougoji

$1-27-99$

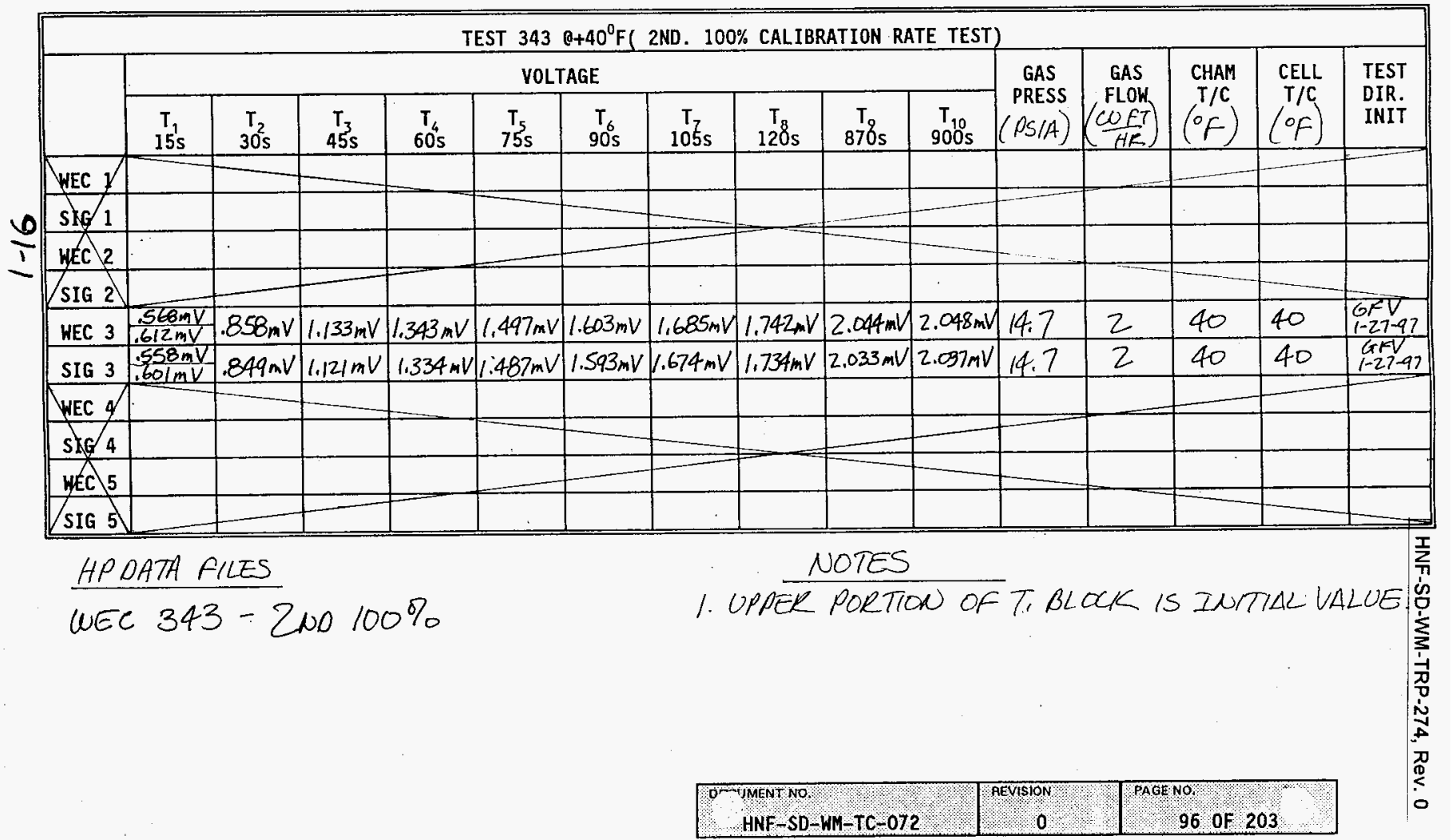




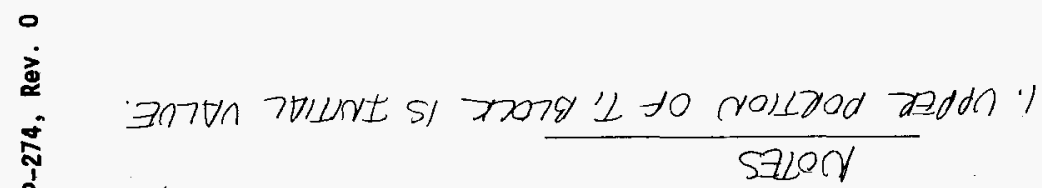

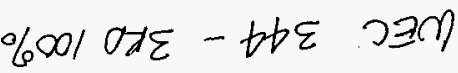

$$
\begin{aligned}
& \text { S्ञात VL } \forall O d t
\end{aligned}
$$

\begin{tabular}{|c|c|c|c|c|c|c|c|c|c|c|c|c|c|c|c|}
\hline$\frac{1}{2}$ & & 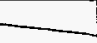 & & & & & & & & & & & 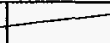 & & S 9IS \\
\hline 1. & & & & & & $m$ & & _ & $\ldots$ & & & & & & $9 \longdiv { J M }$ \\
\hline ti & & & & 1 & 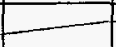 & & & & $x_{2}$ & 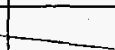 & & & & & DIS \\
\hline & - & & & & & & & & & & & & 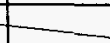 & & $653 \mathrm{~A}$ \\
\hline $\begin{array}{l}L b-12-1 \\
\wedge \mapsto 9\end{array}$ & $\infty$ & ob & 2 & $a l b l$ & $h^{m}+0^{\prime} 2$ & $n^{m} \mathrm{O} \mathrm{O}^{\circ} \mathrm{Z}$ & $\Lambda W_{b \varepsilon L} \cdot 1$ & $\Lambda^{\mathrm{m} / 894}$ & Limfog. & $\Lambda w / 6 b ! \mid$ & $\Lambda^{w_{0}} \mathrm{~s}^{\prime} \cdot$ & AWOEIT & $\Lambda^{N}+98^{\circ}$ & AmLog & $\varepsilon$ פIS \\
\hline $2 b-62-1$ & ob & ot & 2 & $O[D 1$ & $h^{\prime \prime} \varepsilon S O^{\prime} Z$ & hmoso'Z & $\Lambda^{m} / S L^{\prime}$ & AM2b9'1 & (1"ع & AMpOSI & $\left(1 m b t \varepsilon^{\prime}\right.$ & $\Lambda^{w} g \varepsilon|\cdot|$ & $14+98^{\circ}$ & 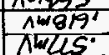 & $\varepsilon \quad J \exists M$ \\
\hline & & 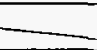 & & & & & & & & & & & 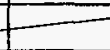 & & 2 9IS \\
\hline & & & & & & & & & $\ldots$ & & & & & & टेग71 \\
\hline & & & & & $\ldots$ & $\longrightarrow$ & & & 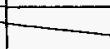 & & & & & & I 90 \\
\hline & $\ldots$ & & & & & & & & & & & & + & & 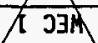 \\
\hline IINI & $\left(-t_{0}\right)$ & $(=10)$ & 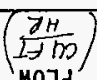 & $(\forall / S d)$ & $\begin{array}{l}\text { So06 } \\
0 t_{\perp}\end{array}$ & $\delta_{1}^{50 L 8}$ & solzt & squI & $\begin{array}{l}506 \\
906 \\
1\end{array}$ & $\begin{array}{c}\text { sgl } \\
\xi_{1}\end{array}$ & $\begin{array}{l}509 \\
11 \\
1\end{array}$ & $\begin{array}{l}\text { sqpt } \\
\varepsilon_{\perp}\end{array}$ & $\begin{array}{l}S 0 \varepsilon \\
z_{1}\end{array}$ & $\begin{array}{l}\text { SG] } \\
\zeta_{1}\end{array}$ & \\
\hline IS 31 & ר173 & WHHJ & SYY & SWG & & & & & בפ & $1170 \AA$ & & & & & \\
\hline
\end{tabular}

$$
\begin{aligned}
& 4 p-L z-1 \\
& \text { yonon t+ }
\end{aligned}
$$

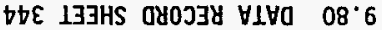


TEST PROCEDURE FOR MEASUREMENT OF PERFORMANCE VS TEMPERATURE WHITTAKER CELL

9.81 DATA RECORD SHEET 351

\begin{tabular}{|c|c|c|c|c|c|c|c|c|c|c|c|c|c|c|c|c|}
\hline \multicolumn{10}{|c|}{ TEST $351+600^{\circ}$ (30\%, 60\%, 90\% CALIBRATION GAS) } \\
\hline
\end{tabular}




\subsection{DATA RECORD SHEET 352}

.

\begin{tabular}{|c|c|c|c|c|c|c|c|c|c|c|c|c|c|c|c|}
\hline \multicolumn{16}{|c|}{ TEST $3520+60^{\circ} \mathrm{F}$ ( 1 ST. $100 \%$ CALIBRATION RATE TEST) } \\
\hline & \multicolumn{10}{|c|}{ VOLTAGE } & \multirow{2}{*}{$\begin{array}{c}\text { GAS } \\
\text { PRESS }\end{array}$} & \multirow{2}{*}{$\begin{array}{l}\text { GAS } \\
\text { FLOW }\end{array}$} & \multirow{2}{*}{$\begin{array}{l}\text { CHAM } \\
\text { T/C }\end{array}$} & \multirow{2}{*}{$\begin{array}{l}\text { CELL } \\
\mathrm{T} / \mathrm{C}\end{array}$} & \multirow{2}{*}{$\begin{array}{l}\text { TEST } \\
\text { DIRI } \\
\text { INIT }\end{array}$} \\
\hline & $T_{15 s}$ & $\begin{array}{c}T_{2} \\
30 s\end{array}$ & $\begin{array}{c}T_{3} \\
45 s\end{array}$ & $\begin{array}{c}T_{4} \\
60 s\end{array}$ & $\begin{array}{c}T_{5} \\
755\end{array}$ & $\begin{array}{l}T_{6} \\
90 s\end{array}$ & $\begin{array}{c}T_{7} \\
1055\end{array}$ & $\begin{array}{c}\mathrm{T}_{\mathrm{T}} \\
120 \mathrm{~s}\end{array}$ & $\begin{array}{c}T_{2} \\
87 \sigma_{s}\end{array}$ & $\begin{array}{c}T_{10} \\
900 \mathrm{~s}\end{array}$ & & & & & \\
\hline \multicolumn{16}{|l|}{ HEC I } \\
\hline \multicolumn{16}{|l|}{ SIG 1} \\
\hline \multicolumn{16}{|l|}{ WEC 2} \\
\hline \multicolumn{16}{|l|}{ SIG 2} \\
\hline \multicolumn{16}{|l|}{ NEC 3} \\
\hline \multicolumn{16}{|l|}{$\operatorname{SIG} 3$} \\
\hline \multicolumn{16}{|l|}{ WEC 4} \\
\hline \multicolumn{16}{|l|}{ SIG 4} \\
\hline \multicolumn{16}{|l|}{ HEC 5} \\
\hline SIG 5 & & & & & & & & & & & & & & & \\
\hline
\end{tabular}

8
8 
TEST PROCEDURE FOR MEASUREMENT OF PERFORMANCE VS TEMPERATURE WHITTAKER CELL

\subsection{DATA RECORD SHEET 353}

\begin{tabular}{|c|c|c|c|c|c|c|c|c|c|c|c|c|c|c|c|c|}
\hline \multicolumn{17}{|c|}{ TEST $3530+60^{\circ} \mathrm{F}(2 \mathrm{ND} .100 \%$ CALIBRATION RATE TEST $)$} \\
\hline & & \multicolumn{10}{|c|}{ VOLTAGE } & \multirow{2}{*}{$\begin{array}{l}\text { GAS } \\
\text { PRESS }\end{array}$} & \multirow{2}{*}{$\begin{array}{l}\text { GAS } \\
\text { FLOW }\end{array}$} & \multirow{2}{*}{$\begin{array}{l}\text { CHAM } \\
T / C\end{array}$} & \multirow{2}{*}{$\begin{array}{c}\text { CELL } \\
\mathrm{T} / \mathrm{C}\end{array}$} & \multirow{2}{*}{$\begin{array}{l}\text { TEST } \\
\text { DIR. }\end{array}$} \\
\hline & & $\begin{array}{c}T_{1}^{\prime} \\
15 s\end{array}$ & $\begin{array}{r}T \\
30 \\
\end{array}$ & $\begin{array}{r}T_{3} \\
45 s\end{array}$ & $\begin{array}{c}T_{4} \\
60\end{array}$ & $\begin{array}{c}T_{5} \\
75\end{array}$ & $\begin{array}{c}\mathrm{T}_{6} \\
90 \mathrm{~s}\end{array}$ & ${ }_{105}^{T} F_{s}$ & $\begin{array}{c}T_{8} \\
120 \mathrm{~s}\end{array}$ & $\begin{array}{c}{ }_{87} \\
87 \sigma_{s}\end{array}$ & $\begin{array}{c}T_{10}{ }_{90} \\
900 \mathrm{~s}\end{array}$ & & & & & \\
\hline & HEC 1 & & & & & & & & & & & & & & & \\
\hline & SIG 1 & & & & & & & & & & & & & & & \\
\hline & WEC 2 & & & & & & & & & & & & & & & \\
\hline & SIG 2 & & & & & & & & & & & & & & & \\
\hline & HEC 3 & & & & & & & & & & & & & & & \\
\hline & SIG 3 & & & & & & & & & & & & & & & \\
\hline & WEC 4 & & & & & & & & & & & & & & & \\
\hline & SIG 4 & & & & & & & & & & & & & & & \\
\hline & HEC 5 & & & & & & & & & & & & & & & \\
\hline & SIG 5 & & & & & & & & & & & & & & & \\
\hline
\end{tabular}




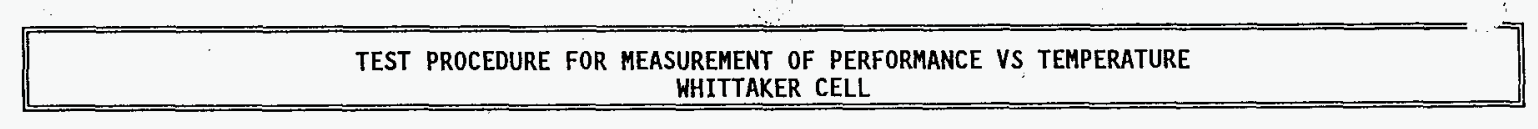

9.84 DATA RECORD SHEET 354

TEST $3540+60^{\circ} \mathrm{F}$ (3RD. 100\% CALIBRATION RATE TEST)

\begin{tabular}{|c|c|c|c|c|c|c|c|c|c|c|c|c|c|c|c|}
\hline \multicolumn{16}{|c|}{ TEST $354 @+60^{\circ} \mathrm{F}$ (3RD. $100 \%$ CALIBRATION RATE TEST) } \\
\hline & \multicolumn{10}{|c|}{ VOLTAGE } & \multirow{2}{*}{$\begin{array}{c}\text { GAS } \\
\text { PRESS }\end{array}$} & \multirow{2}{*}{$\begin{array}{l}\text { GAS } \\
\text { FLOW }\end{array}$} & \multirow{2}{*}{$\begin{array}{l}\text { CHAM } \\
\mathrm{T} / \mathrm{C}\end{array}$} & \multirow{2}{*}{$\begin{array}{c}\text { CELL } \\
T / C\end{array}$} & \multirow{2}{*}{$\begin{array}{l}\text { TEST } \\
\text { DIR. } \\
\text { INIT }\end{array}$} \\
\hline & $\begin{array}{r}\mathrm{T}_{1} \\
15 \mathrm{~s} \\
\end{array}$ & $\begin{array}{r}\mathrm{T}_{2} \\
30 \mathrm{~s} \\
\end{array}$ & $\begin{array}{r}T_{3}{ }^{3} \mathrm{~s} \\
\end{array}$ & $\begin{array}{c}T_{4} \\
60 \mathrm{~s}\end{array}$ & $\begin{array}{c}T_{5} \\
75_{5}\end{array}$ & $\begin{array}{r}T_{6} \\
90 \mathrm{~s}\end{array}$ & $\begin{array}{c}T_{T} \\
105 \mathrm{~s}\end{array}$ & $\begin{aligned} \mathrm{T}_{\mathrm{g}} \\
120 \mathrm{~s}\end{aligned}$ & $\begin{array}{c}T_{1} \\
870_{s}\end{array}$ & $\begin{array}{c}T_{10} \\
900 \mathrm{~s} \\
\end{array}$ & & & & & \\
\hline \multicolumn{16}{|l|}{ HEC 1} \\
\hline SIG 1 & & & & & & & & & & & & & & & 需 \\
\hline \multicolumn{16}{|l|}{ WEC 2} \\
\hline \multicolumn{16}{|l|}{ SIG 2} \\
\hline WEC 3 & & & & & & & & & & & & & & & 突 \\
\hline SIG 3 & & & & & 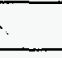 & & & & & & & & & & $\sqrt{3}$ \\
\hline \multicolumn{16}{|l|}{ WEC 4} \\
\hline SIG 4 & & & & & & & & & & & & & & & ?" \\
\hline WEC 5 & & & & & & & & & & & & & & & 0 \\
\hline SIG 5 & & & & & & & & & & & & & & & \\
\hline
\end{tabular}

$\stackrel{8}{:}$ 
TEST PROCEDURE FOR MEASUREMENT OF PERFORMANCE VS TEMPERATURE

WHITTAKER CELL

9.85 DATA RECORD SHEET 361

TEST $361+80^{\circ} \mathrm{F}(30 \%, 60 \%, 90 \%$ CALIBRATION GAS $)$

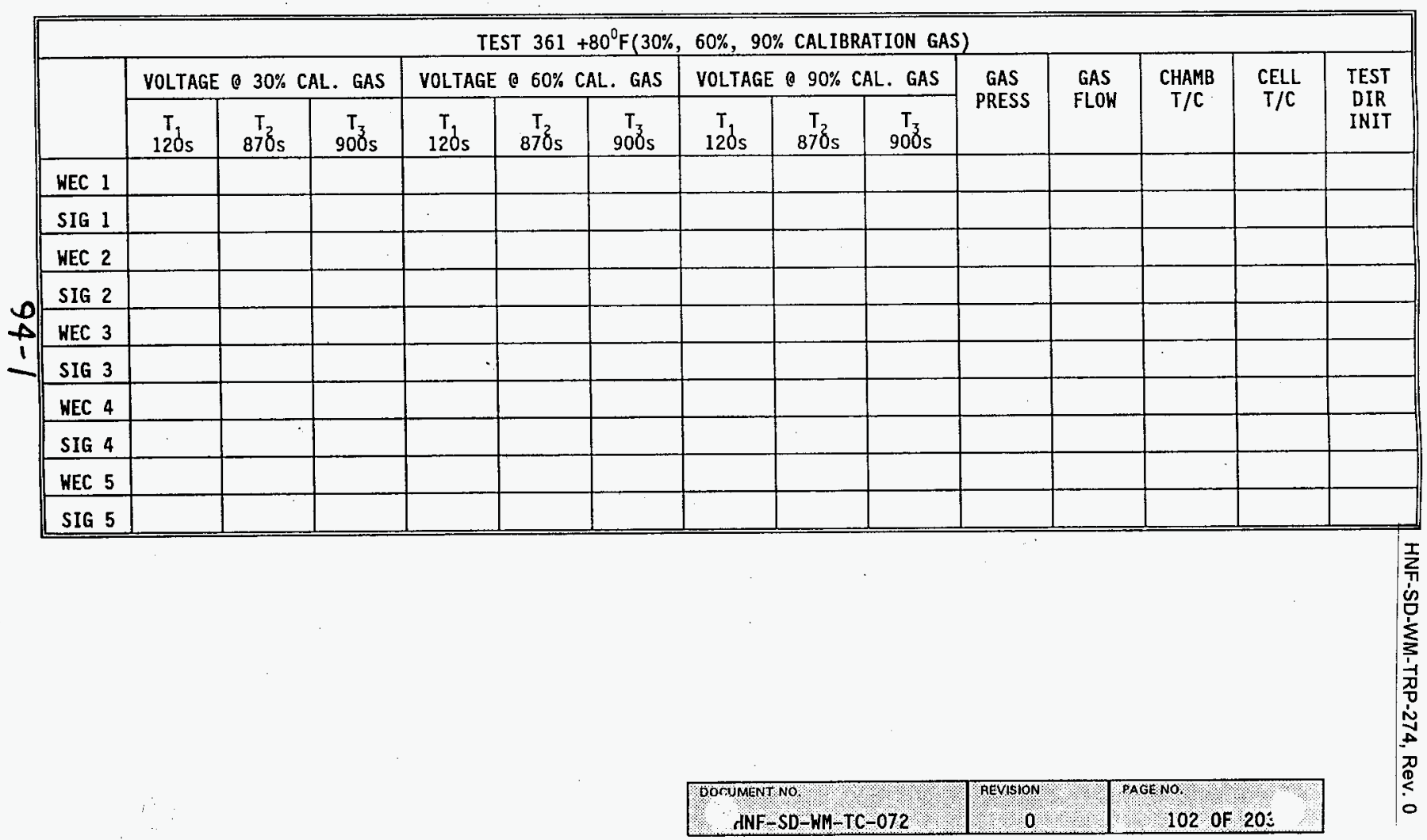


TEST PROCEDURE FOR MEASUREMENT OF PERFORMANCE VS TEMPERATURE WHITAKER CELL

9.86 DATA RECORD SHEET 362

$60^{\circ} \mathrm{F}_{\mathrm{GPV}_{-29}} \mathrm{a7}$

A.F.Vagos
$1-29-99$

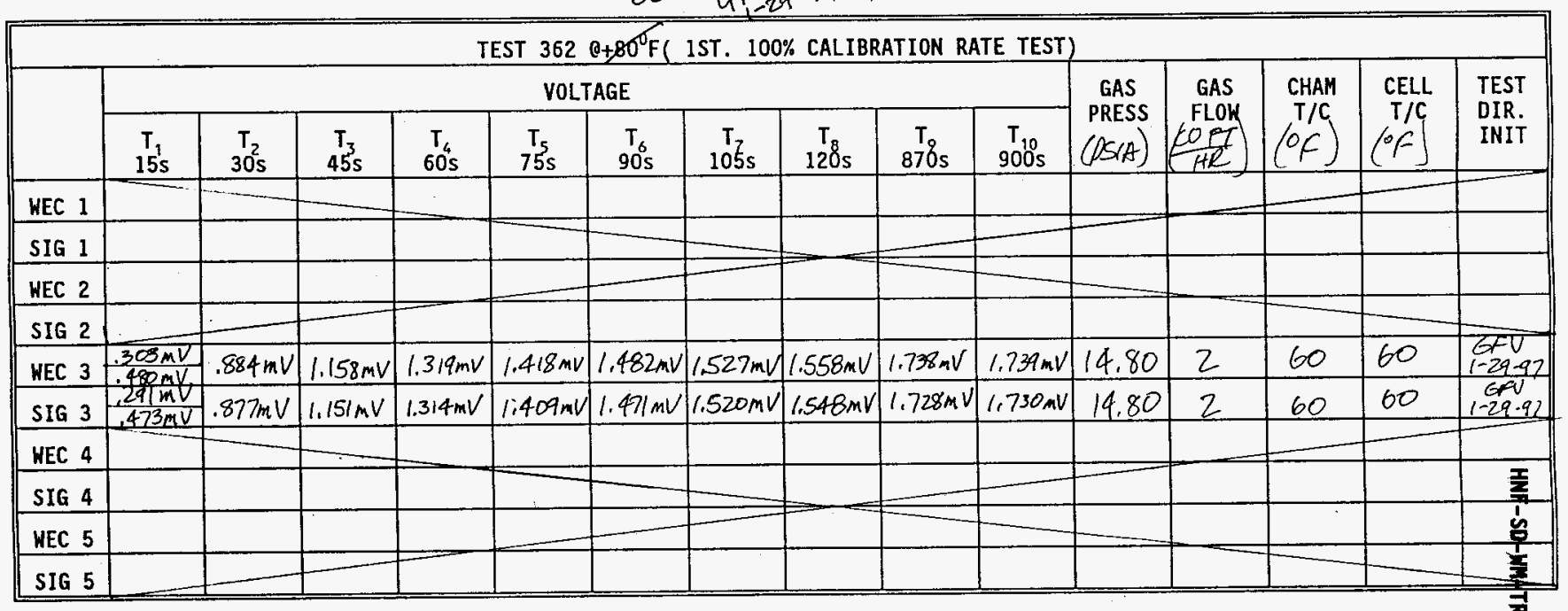

HP DATA FILE

WEE $362-1$ St $100 \% \mathrm{C} 60^{\circ} \mathrm{F}$
NoTES

1. uPPER PorTion of Ti BLock is intel value. 总

\begin{tabular}{|l|l|l}
\hline OOOOUMENT NO \\
HNF-SD-HM-TC-072
\end{tabular} 


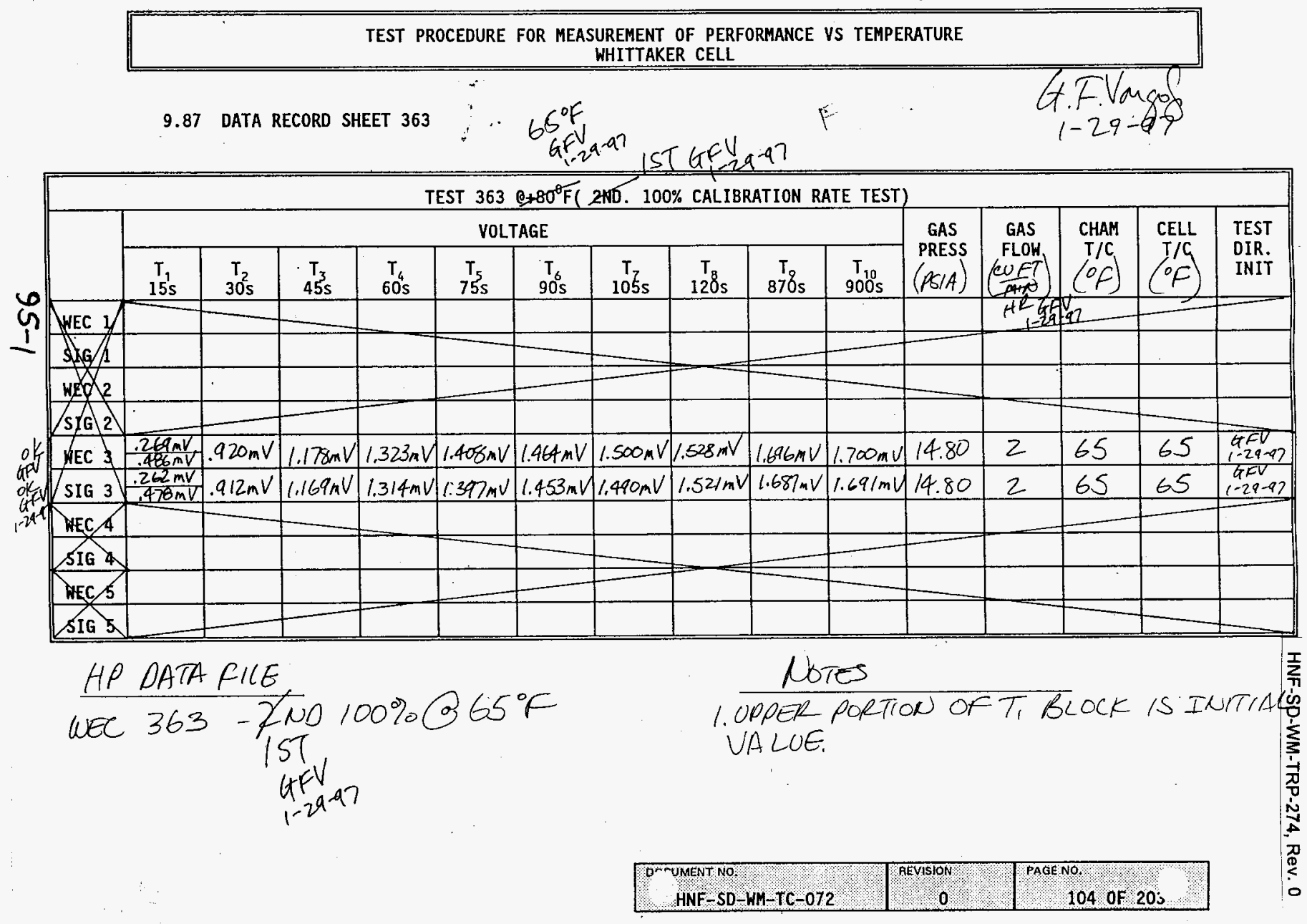


TEST PROCEDURE FOR MEASUREMENT OF PERFORMANCE VS TEMPERATURE WHITTAKER CELL

\subsection{DATA RECORD SHEET 371}

\begin{tabular}{|c|c|c|c|c|c|c|c|c|c|c|c|c|c|c|}
\hline \multicolumn{15}{|c|}{ TEST $371+100^{\circ} \mathrm{F}(30 \%, 60 \%, 90 \%$ CALIBRATION GAS $)$} \\
\hline & \multicolumn{3}{|c|}{ VOLTAGE \& $30 \%$ CAL. GAS } & \multicolumn{3}{|c|}{ VOLTAGE \& $60 \%$ CAL. GAS } & \multicolumn{3}{|c|}{ VOLTAGE O $90 \%$ CAL. GAS } & \multirow{2}{*}{$\begin{array}{c}\text { GAS } \\
\text { PRESS }\end{array}$} & \multirow{2}{*}{$\begin{array}{l}\text { GAS } \\
\text { FLOH }\end{array}$} & \multirow{2}{*}{$\underset{T / C}{\text { CHAMB }}$} & \multirow{2}{*}{$\begin{array}{l}\text { CELL } \\
\mathrm{T} / \mathrm{C}\end{array}$} & \multirow{2}{*}{$\begin{array}{l}\text { TEST } \\
\text { DIR } \\
\text { INIT }\end{array}$} \\
\hline & $\begin{array}{c}\mathrm{T} \\
12{ }_{\mathrm{S}}\end{array}$ & $\begin{array}{r}\mathrm{T}_{2} \\
870 \mathrm{~s} \\
\end{array}$ & $\begin{array}{c}\mathrm{T}_{3} \\
900 \mathrm{~s}\end{array}$ & $\begin{array}{r}\mathrm{T} \mathrm{s}_{\mathrm{s}} \\
120 \mathrm{~s}\end{array}$ & $\begin{array}{c}T_{2} \\
87 \delta_{s}\end{array}$ & $\begin{array}{c}\mathrm{T}_{3} \\
900 \mathrm{~s}\end{array}$ & $\begin{array}{c}\mathrm{T} \mathrm{T}_{\mathrm{s}} \\
120 \mathrm{~s}\end{array}$ & $\begin{array}{c}T^{\top} b_{s} \\
870\end{array}$ & $\begin{array}{c}\mathrm{T}_{\mathrm{z}} \\
900 \mathrm{~s}\end{array}$ & & & & & \\
\hline HEC 1 & & & & & & & & & & & & & & \\
\hline SIG 1 & & & & & & & & & & & & & & \\
\hline WEC 2 & & & & & & . & & & & & & & & \\
\hline SIG 2 & & & & & & & & & & & & & & \\
\hline HEC 3 & & & & & & & & & & & & & & \\
\hline SIG 3 & & & & & & & & & & & & & & \\
\hline MEC 4 & & & & & & & & & & & & & & \\
\hline SIG 4 & & & & & & & & & & & & & & \\
\hline HEC 5 & & & & & & & & & & & & & & \\
\hline SIG 5 & & & & & & & & & & & & & & \\
\hline
\end{tabular}


TEST PROCEDURE FOR MEASUREMENT OF PERFORMANCE VS TEMPERATURE WHITAKER CELL

9.90 DATA RECORD SHEET $372: \because 70^{0} \mathrm{~F}$

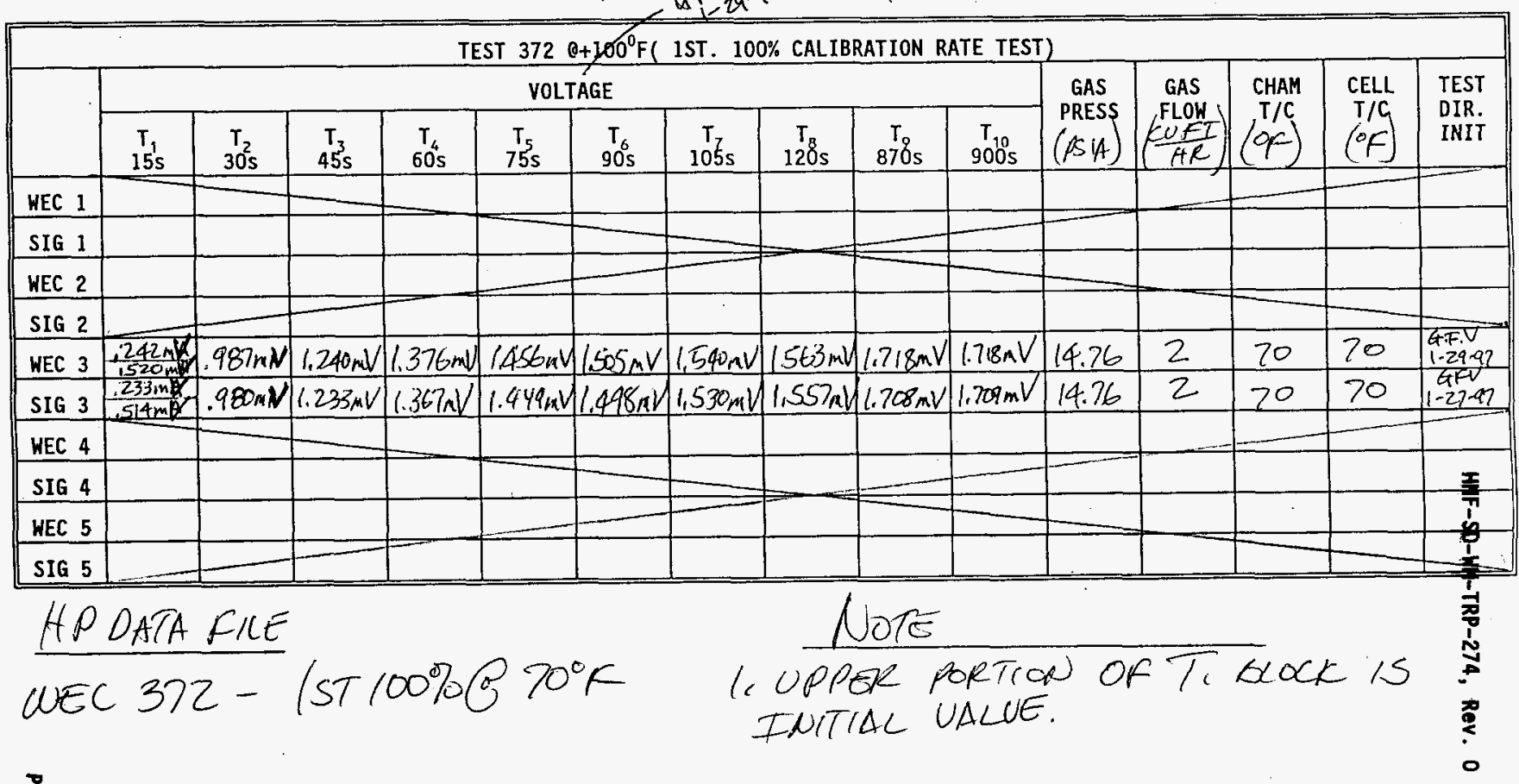

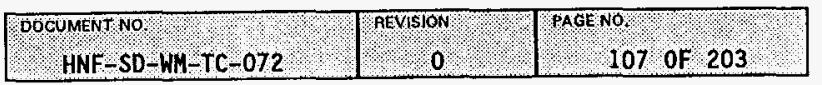


TEST PROCEDURE FOR MEASUREMENT OF PERFORMANCE VS TEMPERATURE WHITTAKER CELL

\subsection{DATA RECORD SHEET 373}

\begin{tabular}{|c|c|c|c|c|c|c|c|c|c|c|c|c|c|c|c|}
\hline \multicolumn{16}{|c|}{ TEST $3730+100^{\circ} \mathrm{F}$ (2ND. $100 \%$ CALIBRATION RATE TEST) } \\
\hline & \multicolumn{10}{|c|}{ VOLTAGE } & \multirow{2}{*}{$\begin{array}{c}\text { GAS } \\
\text { PRESS }\end{array}$} & \multirow{2}{*}{$\begin{array}{l}\text { GAS } \\
\text { FLOW }\end{array}$} & \multirow{2}{*}{$\begin{array}{l}\text { CHAM } \\
\mathrm{T} / \mathrm{C}\end{array}$} & \multirow{2}{*}{$\begin{array}{l}\text { CELL } \\
T / C\end{array}$} & \multirow{2}{*}{$\begin{array}{l}\text { TEST } \\
\text { DIR. } \\
\text { INIT }\end{array}$} \\
\hline & $\begin{array}{c}T_{1} \\
15 s\end{array}$ & $\begin{array}{c}T_{2} \\
30 \mathrm{~s}\end{array}$ & $\begin{array}{r}T_{3} \\
45 s \\
\end{array}$ & $\begin{array}{r}T_{4} \\
600 \mathrm{~s}\end{array}$ & $\begin{array}{r}T_{5} \\
75 \mathrm{~s} \\
\end{array}$ & $\begin{array}{c}\mathrm{T}_{6} \\
90^{\circ} \mathrm{s}\end{array}$ & $\begin{array}{c}T_{7} \\
105 s \\
\end{array}$ & $\begin{array}{c}\mathrm{T}_{8} \\
120 \mathrm{~s} \\
\end{array}$ & $\begin{array}{c}T_{0} \\
870 \mathrm{~s}\end{array}$ & $\begin{array}{c}T_{10} \\
900 s\end{array}$ & & & & & \\
\hline \multicolumn{16}{|l|}{ WEC I } \\
\hline \multicolumn{16}{|l|}{ SIG 1} \\
\hline \multicolumn{16}{|l|}{ WEC 2} \\
\hline \multicolumn{16}{|l|}{ SIG 2} \\
\hline \multicolumn{16}{|l|}{ HEC 3} \\
\hline \multicolumn{16}{|l|}{ SIG 3} \\
\hline \multicolumn{16}{|l|}{ WEC 4} \\
\hline \multicolumn{16}{|l|}{ SIG 4} \\
\hline \multicolumn{16}{|l|}{ WEC 5} \\
\hline SIG 5 & & & & & & & & & & & & & & & \\
\hline
\end{tabular}

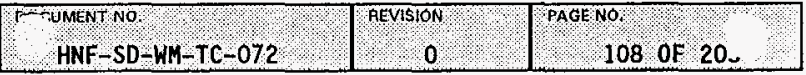


TEST PROCEDURE FOR MEASUREMENT OF PERFORMANCE VS TEMPERATURE

WHITTAKER CELL

9.92 DATA RECORD SHEET 374

TEST $3740+100^{\circ} \mathrm{F}$ (3RD. 100\% CALIBRATION RATE TEST)

\begin{tabular}{|c|c|c|c|c|c|c|c|c|c|c|c|c|c|c|c|}
\hline & \multicolumn{10}{|c|}{ VOLTAGE } & \multirow{2}{*}{$\begin{array}{c}\text { GAS } \\
\text { PRESS }\end{array}$} & \multirow{2}{*}{$\begin{array}{l}\text { GAS } \\
\text { FLOW }\end{array}$} & \multirow{2}{*}{$\begin{array}{l}\text { CHAM } \\
T / C\end{array}$} & \multirow{2}{*}{$\begin{array}{c}\text { CELL } \\
\text { T/C }\end{array}$} & \multirow{2}{*}{$\begin{array}{l}\text { TEST } \\
\text { DIR. } \\
\text { INIT }\end{array}$} \\
\hline & $\begin{array}{c}\mathrm{T}_{15}^{1} \mathrm{~s} \\
\end{array}$ & $\begin{array}{c}\mathrm{T}_{2} \\
30 \mathrm{~s}\end{array}$ & $\begin{array}{r}T_{3} \\
45 \mathrm{~s} \\
\end{array}$ & $\begin{array}{l}T_{6} \\
60 \mathrm{~s}\end{array}$ & $\begin{array}{r}T_{5} \\
7_{5} \\
\end{array}$ & $\begin{array}{c}T_{6}{ }_{9} \\
90 \mathrm{~S}\end{array}$ & $\begin{array}{c}T_{7} \\
105 \mathrm{~s}\end{array}$ & $\begin{array}{r}\mathrm{T}_{8} \\
120 \mathrm{~s}\end{array}$ & $\begin{array}{c}T^{\top} g_{s} \\
870\end{array}$ & $\begin{array}{l}T_{10} \\
900 \mathrm{~s}\end{array}$ & & & & & \\
\hline \multicolumn{16}{|l|}{ WEC 1} \\
\hline \multicolumn{16}{|l|}{ SIG 1} \\
\hline WEC 2 & & & & & & & & & & & & & & & 覃 \\
\hline SIG 2 & & & & & & & & & & & & & & & is \\
\hline HEC 3 & & & & & & & & & & & & & & & 亁 \\
\hline SIG 3 & & & & & & & & & & & & & & & 령 \\
\hline \multicolumn{16}{|l|}{ WEC 4} \\
\hline \multicolumn{16}{|l|}{ SIG 4} \\
\hline HEC 5 & & & & & & & & & & & & & & & 象 \\
\hline SIG 5 & & & & & & & & & & & & & & & 0 \\
\hline
\end{tabular}

8
8
8

HNF-SD-WM-TC-072 100109 of 203


TEST PROCEDURE FOR MEASUREMENT OF PERFORMANCE VS TEMPERATURE

WHITTAKER CELL

\subsection{DATA RECORD SHEET 381}

TEST $381+120^{\circ} \mathrm{F}(30 \%, 60 \%, 90 \%$ CALIBRATION GAS $)$

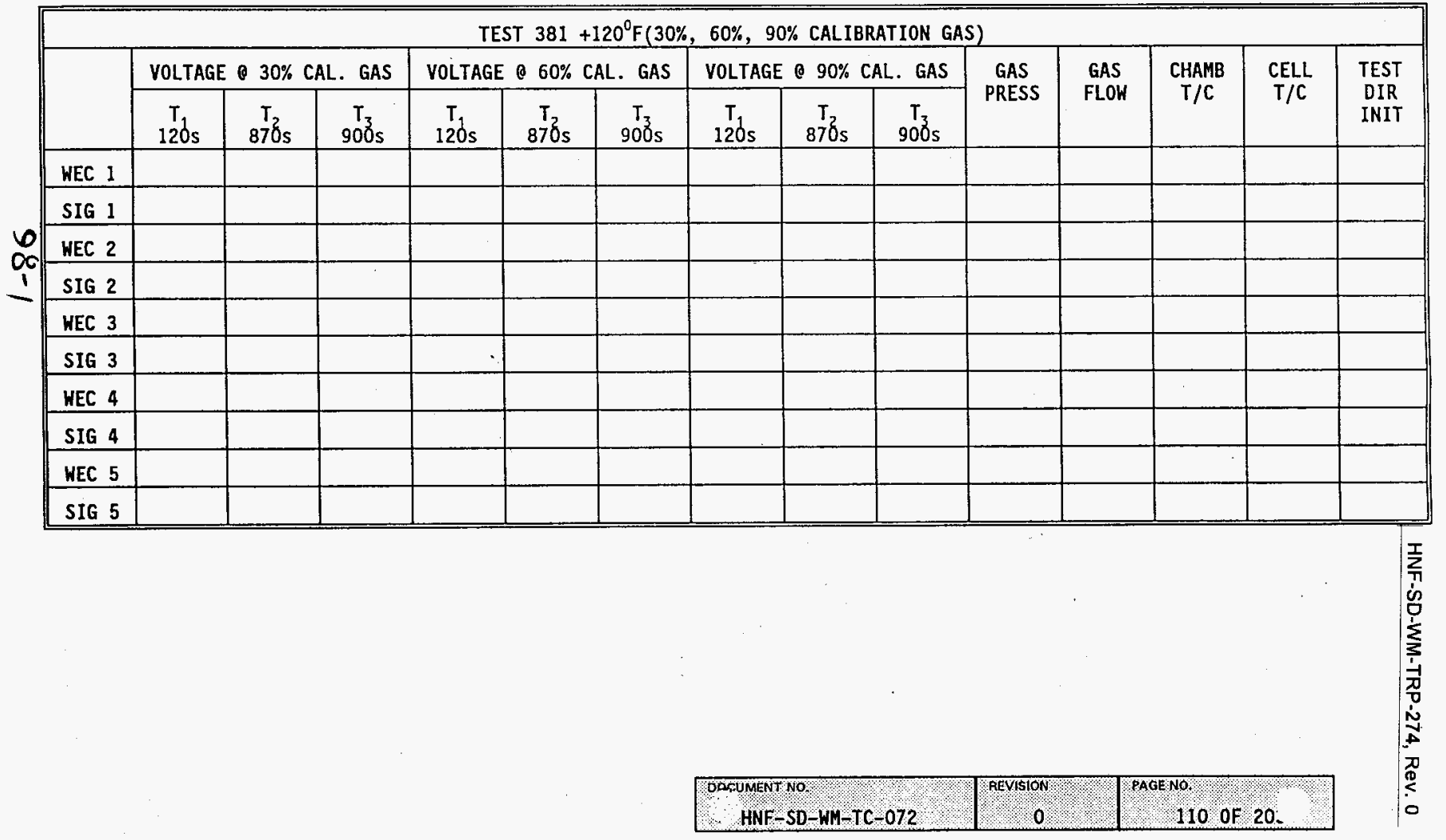


TEST PROCEDURE FOR MEASUREMENT OF PERFORMANCE VS TEMPERATURE

WHITTAKER CELL

9.94 DATA RECORD SHEET 382

\begin{tabular}{|c|c|c|c|c|c|c|c|c|c|c|c|c|c|c|c|}
\hline \multicolumn{16}{|c|}{ IEST $382 \theta+120^{\circ} \mathrm{F}$ ( IST. $100 \%$ CALIBRATION RATE TEST) } \\
\hline & \multicolumn{10}{|c|}{ VOLTAGE } & \multirow{2}{*}{$\begin{array}{l}\text { GAS } \\
\text { PRESS }\end{array}$} & \multirow{2}{*}{$\begin{array}{l}\text { GAS } \\
\text { FLOW }\end{array}$} & \multirow{2}{*}{$\begin{array}{l}\text { CHAM } \\
\mathrm{T} / \mathrm{C}\end{array}$} & \multirow{2}{*}{$\begin{array}{l}\text { CELL } \\
\mathrm{T} / \mathrm{C}\end{array}$} & \multirow{2}{*}{$\begin{array}{l}\text { TEST } \\
\text { DIR. } \\
\text { INIT }\end{array}$} \\
\hline & $\begin{array}{c}T_{1}^{1} \\
15 s\end{array}$ & $\begin{array}{c}\mathrm{T}_{2} \\
30 \mathrm{~s}\end{array}$ & $\begin{array}{c}T_{3} \\
45 s\end{array}$ & $\begin{array}{c}T_{4} \\
60 \mathrm{~s}\end{array}$ & $\begin{array}{l}T_{5} \\
75 s\end{array}$ & $\begin{array}{c}T_{6} \\
90 s\end{array}$ & $\begin{array}{c}T_{1} \\
105 \mathrm{~s}\end{array}$ & $\begin{array}{c}\mathrm{T}_{8} \\
120 \mathrm{~s}\end{array}$ & $\begin{array}{c}\mathrm{T}_{\mathrm{O}} \\
870 \mathrm{~s}\end{array}$ & $\begin{array}{l}T_{10} \\
900 \mathrm{~s}\end{array}$ & & & & & \\
\hline \multicolumn{16}{|l|}{ WEC 1} \\
\hline \multicolumn{16}{|l|}{ SIG 1} \\
\hline \multicolumn{16}{|l|}{ WEC 2} \\
\hline \multicolumn{16}{|l|}{ SIG 2} \\
\hline \multicolumn{16}{|l|}{ WEC 3} \\
\hline \multicolumn{16}{|l|}{ SIG 3} \\
\hline \multicolumn{16}{|l|}{ HEC 4} \\
\hline \multicolumn{16}{|l|}{ SIG 4} \\
\hline HEC 5 & & & & & & & & & & & & & & & 으 \\
\hline SIG 5 & & & & & & & & & & & & & & & \\
\hline
\end{tabular}

8
8
8 
TEST PROCEDURE FOR MEASUREMENT OF PERFORMANCE VS TEMPERATURE

WHITTAKER CELL

\subsection{DATA RECORD SHEET 383}

TEST $3830+120^{\circ} \mathrm{F}$ ( 2ND. $100 \%$ CALIBRATION RATE TEST)

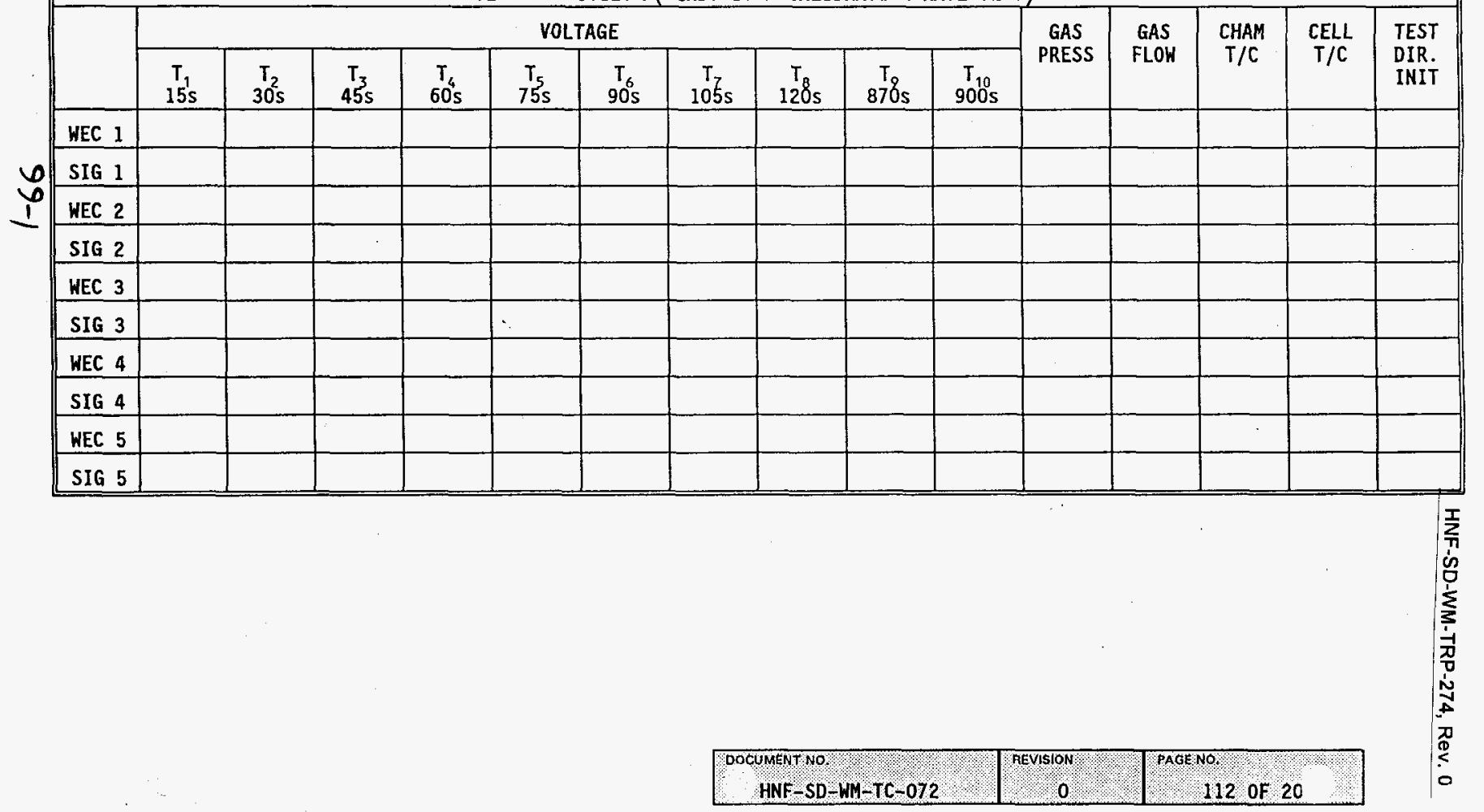




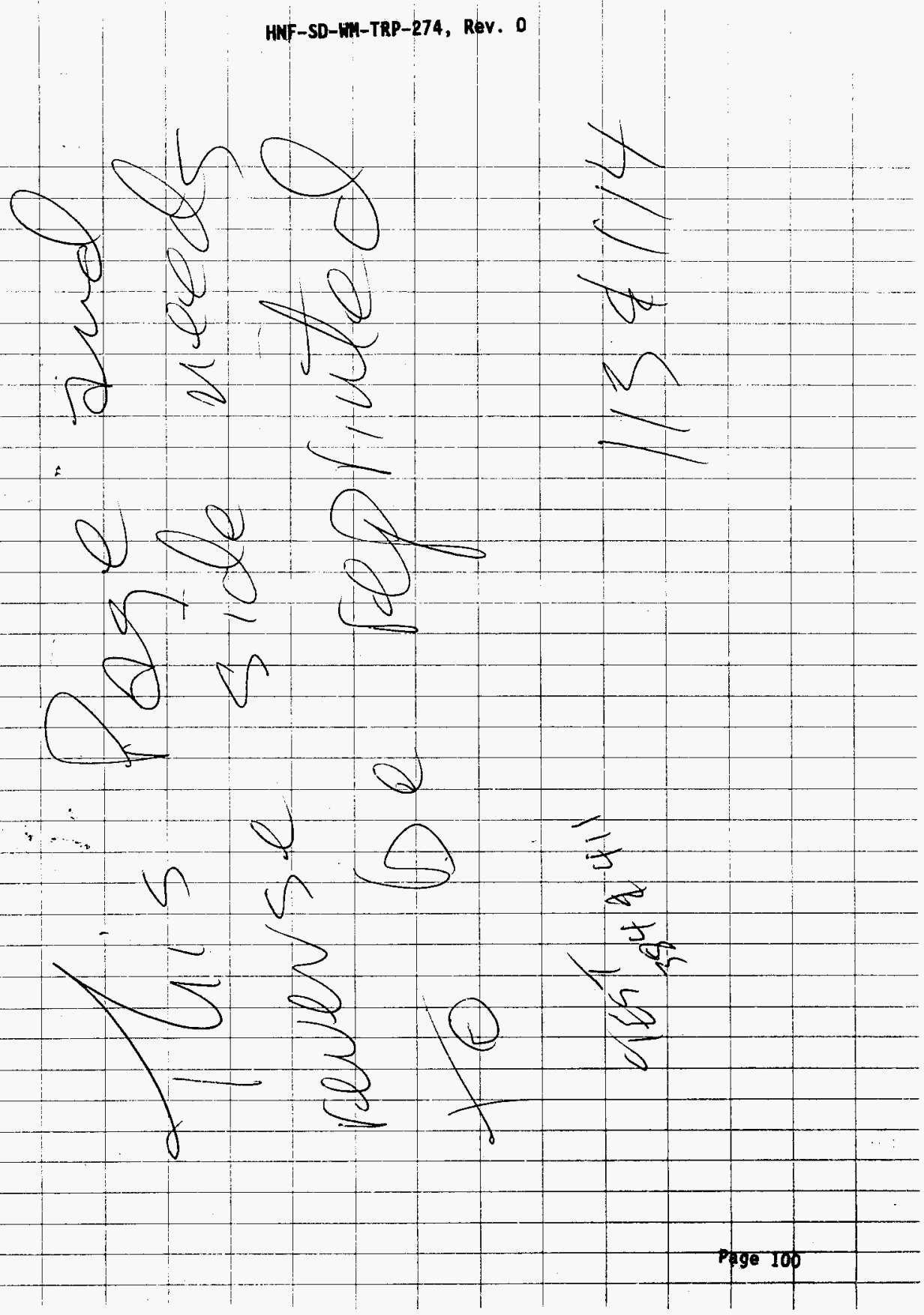


HNF-SP-2WN-TRP- 274 , her 0

This Page Intentionally Blank

$100-1$ 
TEST PROCEDURE FOR MEASUREMENT OF PERFORMANCE VS TEMPERATURE WHITAKER CELL

9.98 DATA RECORD SHEET 412

$100^{\circ} \mathrm{F}, 1 / 31 / 97$ $1 / 31 / 97$

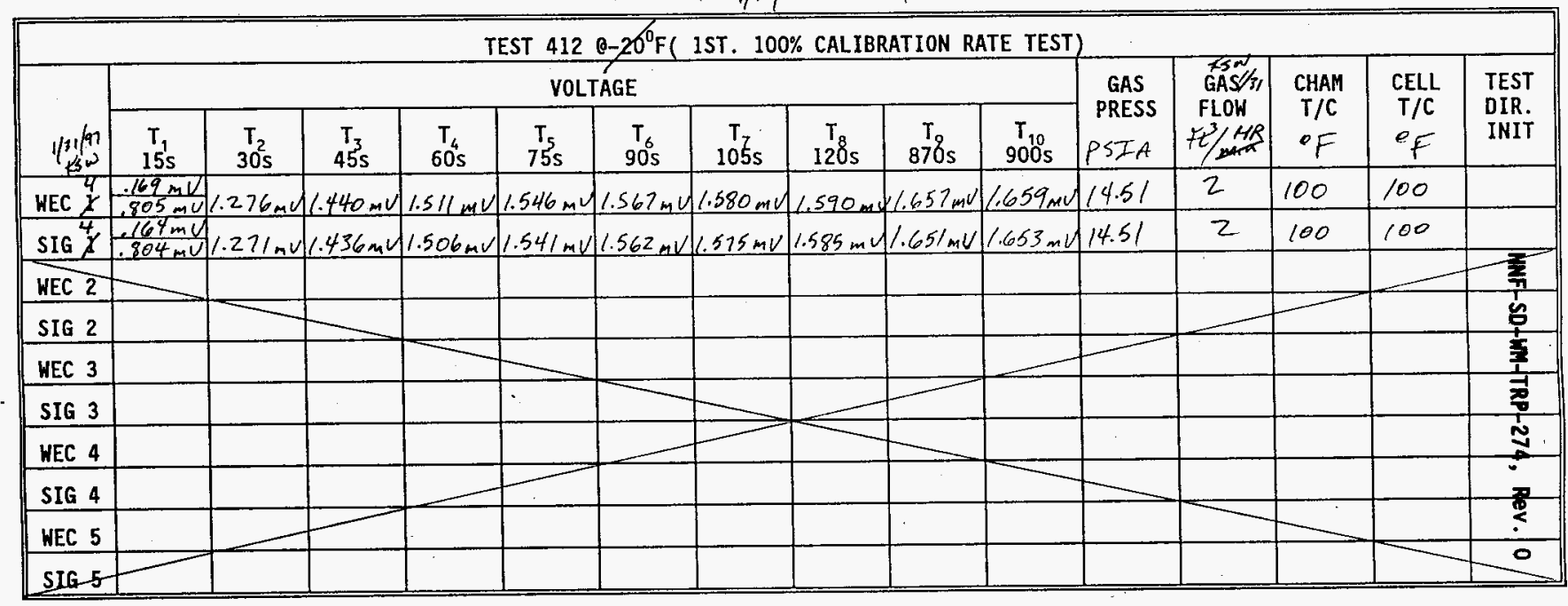

HP DATA FILE

WED $412-1^{\text {ST } \operatorname{Run} 100 \%} \odot 100^{\circ} \mathrm{F}$
NOTES

The top entry of $T_{1}$ is the initial cell value@ Time $\phi$. The bottom entry is the value 15 seconds.

莡
음

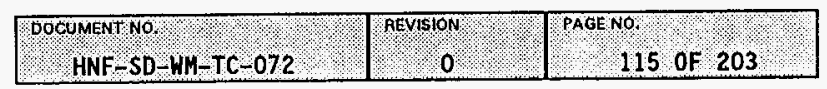




\subsection{DATA RECORD SHEET 413}

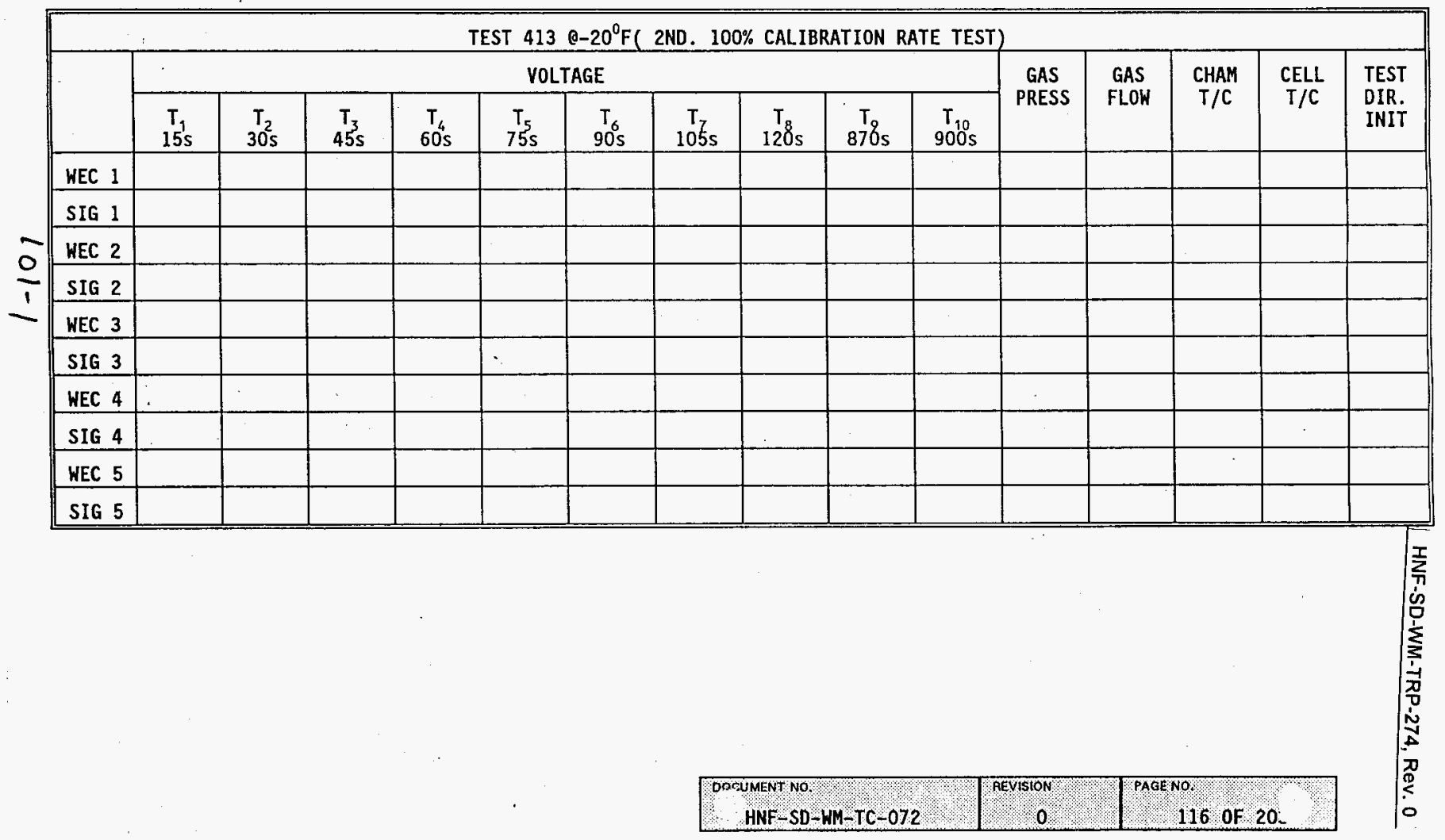


TEST PROCEDURE FOR MEASUREMENT OF PERFORMANCE VS TEMPERATURE

\section{WHITTAKER CELL}

9.100 DATA RECORD SHEET 414

TEST $4140-20^{\circ} \mathrm{F}$ ( 3RD, 100\% CALIBRATION RATE TEST)

\begin{tabular}{|c|c|c|c|c|c|c|c|c|c|c|c|c|c|c|c|}
\hline & \multicolumn{10}{|c|}{ VOLTAGE } & \multirow{2}{*}{$\begin{array}{c}\text { GAS } \\
\text { PRESS }\end{array}$} & \multirow{2}{*}{$\begin{array}{l}\text { GAS } \\
\text { FLOW }\end{array}$} & \multirow{2}{*}{$\begin{array}{l}\text { CHAM } \\
\mathrm{T} / \mathrm{C}\end{array}$} & \multirow{2}{*}{$\begin{array}{l}\text { CELL } \\
\text { T/C }\end{array}$} & \multirow{2}{*}{$\begin{array}{l}\text { TEST } \\
\text { DIR. } \\
\text { INIT }\end{array}$} \\
\hline & $\begin{array}{r}T_{1} \\
15 s \\
\end{array}$ & $\begin{array}{r}T_{2} \\
30 \mathrm{~s} \\
\end{array}$ & $\begin{array}{r}T_{3} \\
45 s \\
\end{array}$ & $\begin{array}{r}T_{4} \\
60 \mathrm{~s} \\
\end{array}$ & $\begin{array}{r}T_{5} \\
75 \mathrm{~s} \\
\end{array}$ & $\begin{array}{r}T_{6} \\
90 \mathrm{~s} \\
\end{array}$ & $\begin{array}{c}\mathrm{T}_{7} \\
105 \mathrm{~s}\end{array}$ & $\begin{array}{c}T_{8} \\
120 \mathrm{~s} \\
\end{array}$ & $\begin{array}{r}T_{8} \\
870 \mathrm{~s} \\
\end{array}$ & $\begin{array}{r}T_{10} \\
900 \mathrm{~s} \\
\end{array}$ & & & & & \\
\hline \multicolumn{16}{|l|}{ WEC 1} \\
\hline \multicolumn{16}{|l|}{ SIG 1} \\
\hline \multicolumn{16}{|l|}{ WEC 2} \\
\hline \multicolumn{16}{|l|}{ SIG 2} \\
\hline \multicolumn{16}{|l|}{ HEC 3} \\
\hline \multicolumn{16}{|l|}{ SIG 3} \\
\hline WEC 4 & & & & & & & & & & & & & & & 8 \\
\hline SIG 4 & & & & & & & & & & & & & & & 蛋 \\
\hline WEC 5 & & & & & & & & & & & & & & & 0 \\
\hline SIG 5 & & & & & & & & & & & & & & & \\
\hline
\end{tabular}

옹
융 
TEST PROCEDURE FOR MEASUREMENT OF PERFORMANCE VS TEMPERATURE

WHITTAKER CELL

\subsection{DATA RECORD SHEET 421}

TEST $4210^{\circ} \mathrm{F}(30 \%, 60 \%, 90 \%$ CALIBRATION GAS $)$

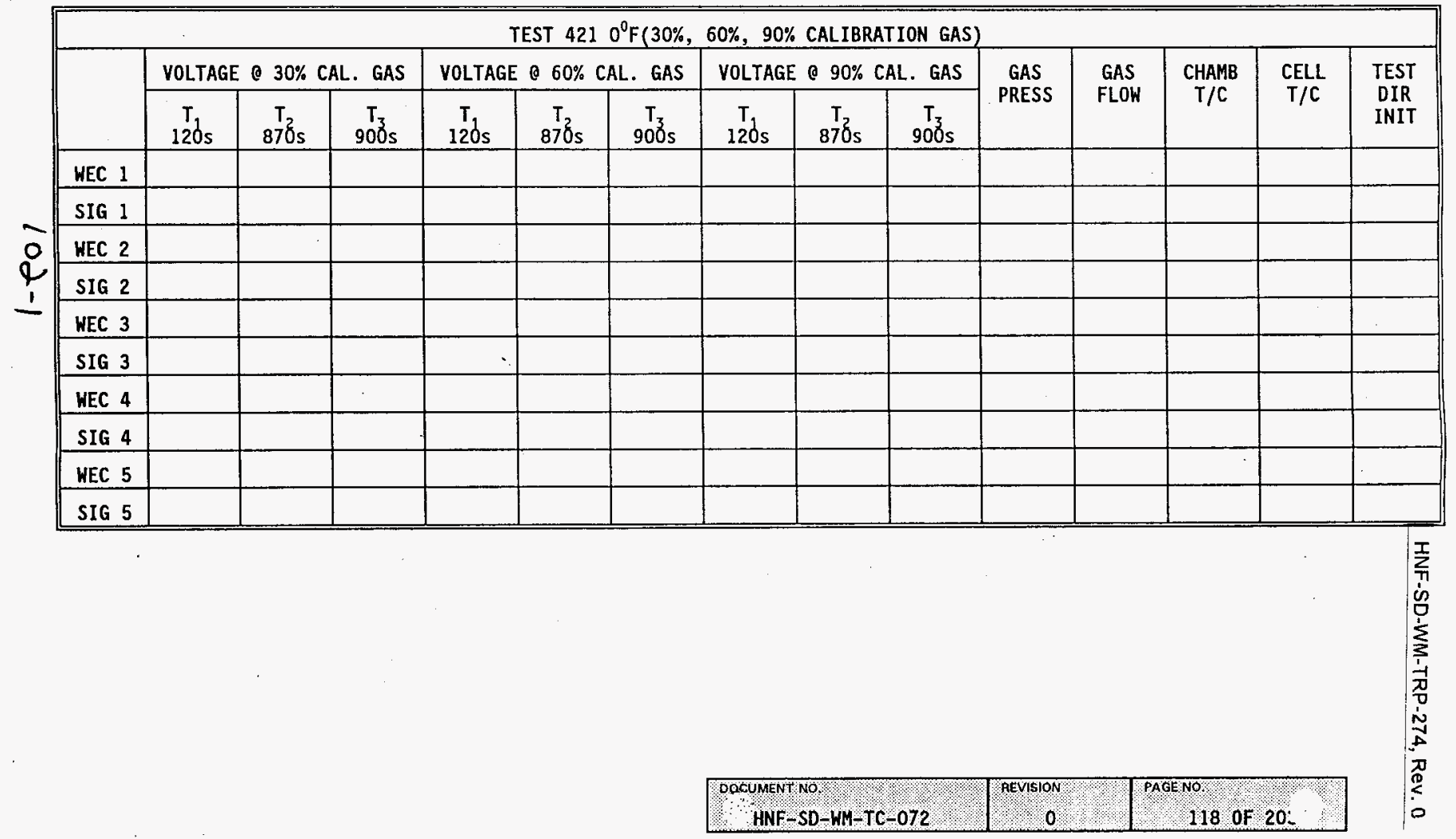


TEST PROCEDURE FOR MEASUREMENT OF PERFORMANCE VS TEMPERATURE

WHITTAKER CELL

9.102 DATA RECORD SHEET 422 KS: $1 / 31 / 97$ $120^{\circ} \mathrm{F}$

\begin{tabular}{|c|c|c|c|c|c|c|c|c|c|c|c|c|c|c|c|}
\hline \multicolumn{16}{|c|}{ TEST $42200^{6} \mathrm{~F}$ ( IST. $100 \%$ CALIBRATION RATE TEST) } \\
\hline & \multicolumn{10}{|c|}{ VOLTAGE } & \multirow{2}{*}{$\begin{array}{c}\text { GAS } \\
\text { PRESS } \\
(P S \mid A)\end{array}$} & \multirow{2}{*}{$\begin{array}{c}\text { GASU } \\
\text { FLOW } \\
F L^{3} / H R \\
\end{array}$} & \multirow{2}{*}{$\begin{array}{c}\text { CHAM } \\
T / C \\
K C^{\circ} \mathrm{F}\end{array}$} & \multirow{2}{*}{$\begin{array}{l}\text { CELL } \\
T / C \\
{ }^{O} F\end{array}$} & \multirow{2}{*}{$\begin{array}{l}\text { TEST } \\
\text { DIR. } \\
\text { INIT }\end{array}$} \\
\hline & $\begin{array}{c}T_{1} \\
15 s\end{array}$ & $\begin{array}{r}\mathrm{T}_{2} \\
30^{2} \mathrm{~s}\end{array}$ & $\begin{array}{r}\mathrm{T}_{3} \\
45^{2} \mathrm{~s}\end{array}$ & $\begin{array}{c}T_{4} \\
605\end{array}$ & $\begin{array}{c}T_{5} \\
75 s\end{array}$ & $\begin{array}{r}\mathrm{T}_{6} \\
90 \mathrm{~s} \\
\end{array}$ & ${ }_{105 s}$ & $\begin{array}{c}T_{8} \\
120 s\end{array}$ & $\mathrm{~T}_{8}$ & $\begin{array}{c}T_{10} \\
900 s\end{array}$ & & & & & \\
\hline \multicolumn{16}{|l|}{ WEC 1} \\
\hline \multicolumn{16}{|l|}{ SIG 1} \\
\hline \multicolumn{16}{|l|}{ NEC 2} \\
\hline \multicolumn{16}{|l|}{ SIG 2} \\
\hline \multicolumn{16}{|l|}{ WEC 3} \\
\hline \multicolumn{16}{|l|}{ SIG 3} \\
\hline WEC 4 & $.202 \mathrm{mV}$ & $1.294 \mathrm{mV}$ & $1.389 \mathrm{mV}$ & $1.431 \mathrm{mV}$ & $1.453 \mathrm{mV}$ & $1.468 \mathrm{mV}$ & $1.478 \mathrm{mV}$ & $1.487 \mathrm{me}$ & $1.578 \mathrm{~m} \mathrm{~V}$ & $1.519 \mathrm{mv}$ & 14.51 & 2 & 120 & 120 & 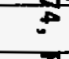 \\
\hline SIG 4 & $.201 \mathrm{mV}$ & $1.292 \mathrm{mV}$ & $1.386 \mathrm{mV}$ & $1.428 \mathrm{mu}$ & $1.450 \mathrm{mV}$ & $1.465 \mathrm{mV}$ & $1.475 \mathrm{mV}$ & $1.484 \mathrm{~m} \mathrm{~V}$ & $1.576 \mathrm{mV}$ & $1.577 \mathrm{mv}$ & 14.51 & $z$ & 120 & 120 & 要 \\
\hline HEC 5 & & & & & & & & & & & & & & & 0 \\
\hline SIG 5 & & & & & & & & & & & & & & & \\
\hline
\end{tabular}

\section{HP DATA FILE}

WEC $422-1$ ST Run, $100 \% \odot 120^{\circ} \mathrm{F}$

\section{NOTES}

1. The top EUTRY FOR $T_{1}$ IS THE INITIAL TIME ZERO VALUE, THE BOTTOM IS THE $15 \mathrm{sec}$ VALUE.

홍 
TEST PROCEDURE FOR MEASUREMENT OF PERFORMANCE VS TEMPERATURE

WHITTAKER CELL

\subsection{DATA RECORD SHEET 423}

TEST $42300^{\circ} \mathrm{F}$ ( 2ND. 100\% CALIBRATION RATE TEST)

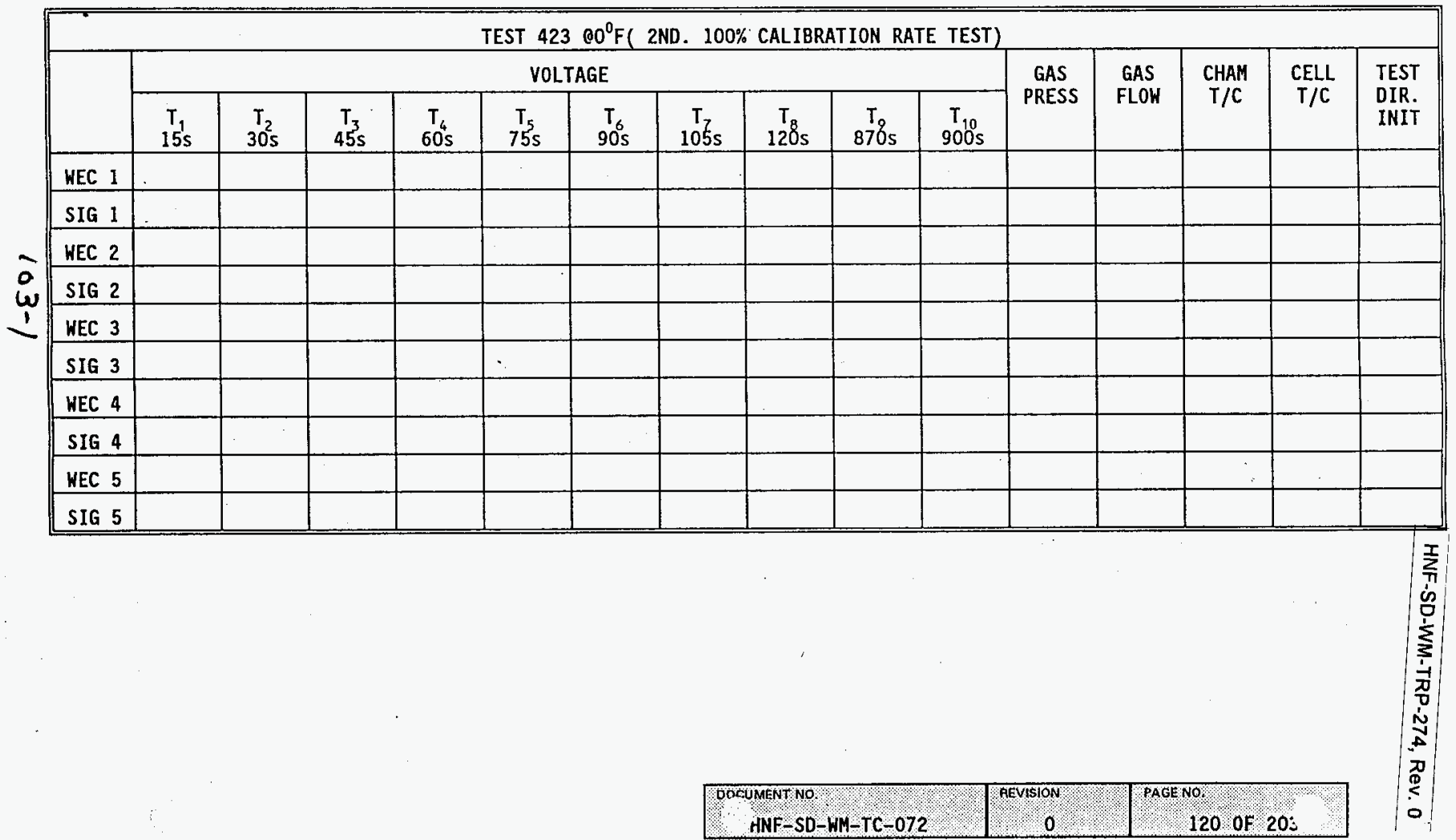




\section{TEST PROCEDURE FOR MEASUREMENT OF PERFORMANCE VS TEMPERATURE}

WHITTAKER CELL

\subsection{DATA RECORD SHEET 424}

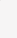

\begin{tabular}{|c|c|c|c|c|c|c|c|c|c|c|c|c|c|c|c|}
\hline \multicolumn{16}{|c|}{ TEST $42490^{\circ} \mathrm{F}$ ( 3RD. 100\% CALIBRATION RATE TEST) } \\
\hline & \multicolumn{10}{|c|}{ VOLTAGE } & \multirow{2}{*}{$\begin{array}{l}\text { GAS } \\
\text { PRESS }\end{array}$} & \multirow{2}{*}{$\begin{array}{l}\text { GAS } \\
\text { FLOW }\end{array}$} & \multirow{2}{*}{$\begin{array}{l}\text { CHAM } \\
T / C\end{array}$} & \multirow{2}{*}{$\begin{array}{l}\text { CELLL } \\
T / C\end{array}$} & \multirow{2}{*}{$\begin{array}{l}\text { TEST } \\
\text { DIR. } \\
\text { INIT }\end{array}$} \\
\hline & $\begin{array}{c}T \\
15 s \\
15\end{array}$ & $\begin{array}{c}\mathrm{T}_{2} \\
30 \mathrm{~s}\end{array}$ & $\begin{array}{r}T_{3} \\
45^{3}\end{array}$ & $\begin{array}{c}T_{4} \\
60 \mathrm{~s}\end{array}$ & $\begin{array}{c}T_{5}^{5} \\
75 \mathrm{~s}\end{array}$ & $\begin{array}{c}T_{6}{ }_{6} \\
90 s\end{array}$ & $\begin{array}{c}\mathrm{T}+ \\
105 \mathrm{~s}\end{array}$ & $\begin{array}{c}T_{1} \\
120 \mathrm{~s}\end{array}$ & $\begin{array}{c}\mathrm{T} / \mathrm{s}_{\mathrm{s}} \\
87 \mathrm{~s}_{\mathrm{s}}\end{array}$ & $\begin{array}{c}T_{10} \\
900 \mathrm{~s}\end{array}$ & & & & & \\
\hline \multicolumn{16}{|l|}{ WEC 1} \\
\hline \multicolumn{16}{|l|}{ SIG 1} \\
\hline \multicolumn{16}{|l|}{ WEC 2} \\
\hline \multicolumn{16}{|l|}{$\operatorname{sig} 2$} \\
\hline \multicolumn{16}{|l|}{ HEC 3} \\
\hline \multicolumn{16}{|c|}{ SIG 3} \\
\hline HEC 4 & & & & & & & & & & & & & & & \pm \\
\hline SIG 4 & & & & & & & & & & & & & & & 密 \\
\hline \multicolumn{16}{|c|}{ WEC 5} \\
\hline SIG 5 & & & & & & & & & & & & & & & \\
\hline
\end{tabular}

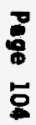

\begin{tabular}{|c|c|c|}
\hline DOCOMENT SO & AEVISION & PAGENO \\
\hline HNF - SD - HM-TC-072 & 0 & 121 of 203 \\
\hline
\end{tabular}


9.105 DATA RECORD SHEET 431

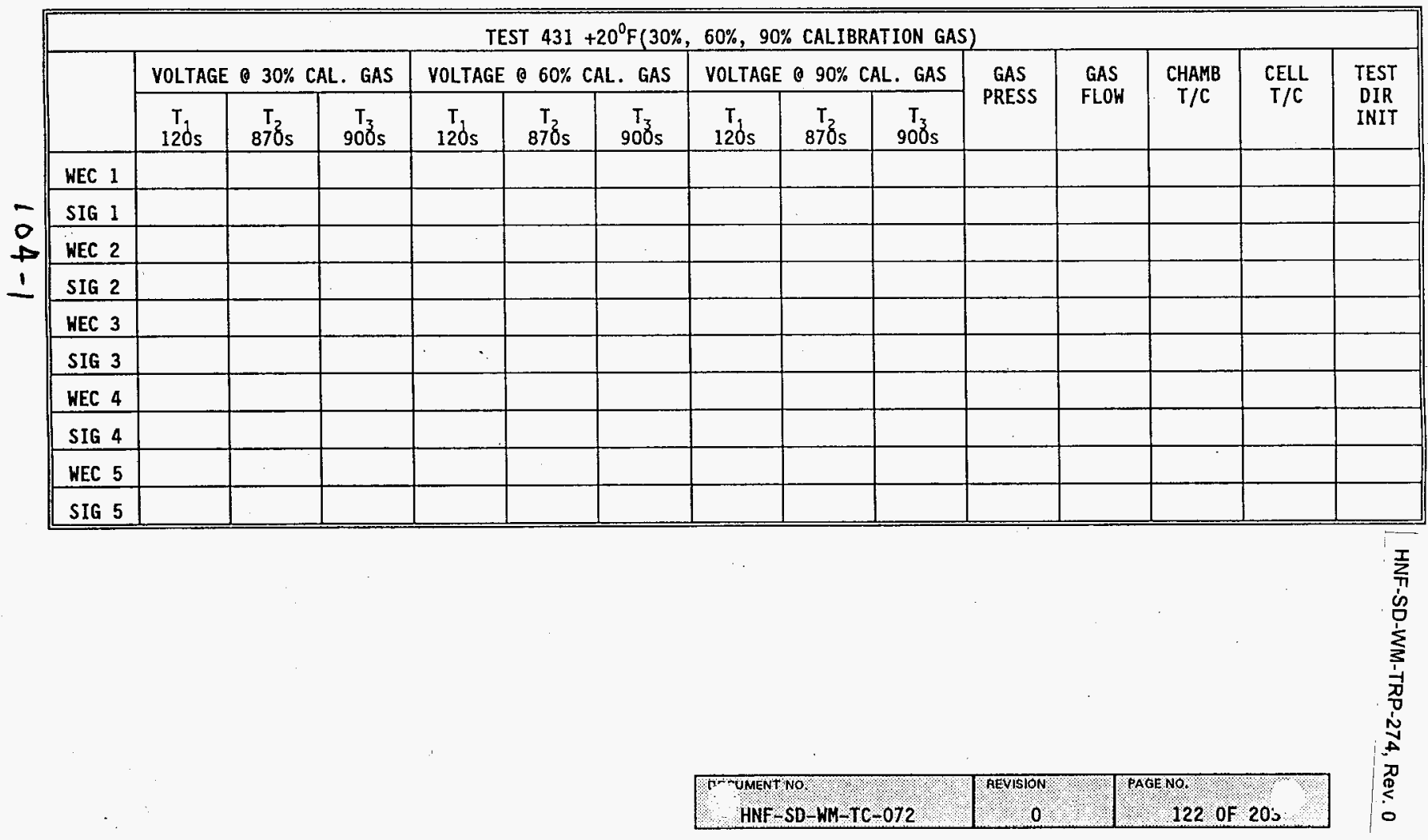


9. 106 DATA RECORD SHEET 432

\begin{tabular}{|c|c|c|c|c|c|c|c|c|c|c|c|c|c|c|c|}
\hline \multicolumn{16}{|c|}{ TEST $4320+20^{\circ} \mathrm{F}(1 \mathrm{ST} .100 \%$ CALIBRATION RATE TEST) } \\
\hline & \multicolumn{10}{|c|}{ VOLTAGE } & \multirow{2}{*}{$\begin{array}{l}\text { GAS } \\
\text { PRESS }\end{array}$} & \multirow{2}{*}{$\begin{array}{l}\text { GAS } \\
\text { FLOW }\end{array}$} & \multirow{2}{*}{$\begin{array}{l}\text { CHAM } \\
T / C\end{array}$} & \multirow{2}{*}{$\begin{array}{l}\text { CELL } \\
T / C\end{array}$} & \multirow{2}{*}{$\begin{array}{l}\text { TEST } \\
\text { DIR. } \\
\text { INIT }\end{array}$} \\
\hline & $\begin{array}{c}T_{1} \\
15 s\end{array}$ & $\begin{array}{r}\mathrm{T}_{2} \\
30 \mathrm{~s} \\
\end{array}$ & $\begin{array}{r}T_{3} \\
45 \\
\end{array}$ & $\begin{array}{c}T_{4} \\
60 \mathrm{~s}\end{array}$ & $\begin{array}{r}T_{5} \\
755 s \\
\end{array}$ & $\begin{array}{c}T_{6} \\
90 \mathrm{~S} \\
\end{array}$ & $\begin{array}{c}\mathrm{T}_{\mathrm{Z}} \\
105 \mathrm{~s}\end{array}$ & $\begin{array}{c}\mathrm{T}_{8} \\
120 \mathrm{~s} \\
\end{array}$ & $\begin{array}{c}T_{\mathrm{Q}} \\
87 \mathrm{~s}^{2}\end{array}$ & $\begin{array}{r}\mathrm{T}_{10} \\
900 \mathrm{~s} \\
\end{array}$ & & & & & \\
\hline \multicolumn{16}{|l|}{ WEC 1} \\
\hline \multicolumn{16}{|l|}{ SIG 1} \\
\hline \multicolumn{16}{|l|}{ WEC 2} \\
\hline \multicolumn{16}{|l|}{ SIG 2} \\
\hline \multicolumn{16}{|l|}{ WEC 3} \\
\hline \multicolumn{16}{|l|}{ SIG 3} \\
\hline \multicolumn{16}{|l|}{ WEC 4} \\
\hline SIG 4 & & & & & & & & & & & & & & & 交 \\
\hline WEC 5 & & & & & & & & & & & & & & & o \\
\hline SIG 5 & & & & & & & & & & & & & & & \\
\hline
\end{tabular}

莕
品

\begin{tabular}{|c|c|c|}
\hline DOGUMEN Y NO & AEVISION & PAGENO. \\
\hline 4 HNF - SD - WM-TC-072 & 0 & $1230 \mathrm{~F} 203$ \\
\hline
\end{tabular}


9.107 DATA RECORD SHEET 433

TEST $433 \theta+20^{\circ} \mathrm{F}$ ( 2ND. 100\% CALIBRATION RATE TEST)

m.

\begin{tabular}{|c|c|c|c|c|c|c|c|c|c|c|c|c|c|c|c|}
\hline \multicolumn{16}{|c|}{ TEST $4330+20^{\circ} \mathrm{F}$ ( 2ND. $100 \%$ CALIBRATION RATE TEST) } \\
\hline & \multicolumn{10}{|c|}{ VOLTAGE } & \multirow{2}{*}{$\begin{array}{l}\text { GAS } \\
\text { PRESS }\end{array}$} & \multirow{2}{*}{$\begin{array}{l}\text { GAS } \\
\text { FLOW }\end{array}$} & \multirow{2}{*}{$\begin{array}{l}\text { CHAM } \\
\mathrm{T} / \mathrm{C}\end{array}$} & \multirow{2}{*}{$\begin{array}{c}\text { CELL } \\
\mathrm{T} / \mathrm{C}\end{array}$} & \\
\hline & $\begin{array}{c}\mathrm{T}_{1} \\
15 \mathrm{~s} \\
\end{array}$ & $\begin{array}{r}T_{2} \\
30 \mathrm{~s} \\
\end{array}$ & $\begin{array}{c}T_{3} \\
455\end{array}$ & $\begin{array}{r}T_{4} \\
60 \mathrm{~s} \\
\end{array}$ & $\begin{array}{r}T_{5} \\
75 s \\
\end{array}$ & $\begin{array}{c}T_{6} \\
90 \mathrm{~s} \\
\end{array}$ & ${ }_{105 \mathrm{~s}}^{\mathrm{T}}$ & $\begin{array}{r}T_{8} \\
120 s \\
\end{array}$ & $\begin{array}{c}T_{8} \\
87 \% s \\
\end{array}$ & $\begin{array}{c}T_{10} \\
900 \mathrm{~s}\end{array}$ & & & & & \\
\hline \multicolumn{15}{|l|}{ WEC 1} & \\
\hline \multicolumn{15}{|l|}{ SIG 1} & \\
\hline \multicolumn{15}{|l|}{ WEC 2} & \\
\hline \multicolumn{15}{|l|}{ SIG 2} & \\
\hline \multicolumn{15}{|l|}{ HEC 3} & \\
\hline \multicolumn{15}{|l|}{ SIG 3} & \\
\hline \multicolumn{15}{|l|}{ WEC 4} & \\
\hline \multicolumn{15}{|l|}{ SIG 4} & \\
\hline \multicolumn{15}{|l|}{ HEC 5} & \\
\hline SIG 5 & & & & & & & & & & & & & & & \\
\hline
\end{tabular}


TEST PROCEDURE FOR MEASUREMENT OF PERFORMANCE VS TEMPERATURE

WHITTAKER CELL

9.108 DATA RECORD SHEET 434

TEST $4340+20^{\circ} \mathrm{F}$ ( 3 RD. $100 \%$ CALIBRATION RATE TEST)

\begin{tabular}{|c|c|c|c|c|c|c|c|c|c|c|c|c|c|c|c|}
\hline & \multicolumn{10}{|c|}{ VOLTAGE } & \multirow{2}{*}{$\begin{array}{c}\text { GAS } \\
\text { PRESS }\end{array}$} & \multirow{2}{*}{$\begin{array}{l}\text { GAS } \\
\text { FLOW }\end{array}$} & \multirow{2}{*}{$\begin{array}{l}\text { CHAM } \\
\mathrm{T} / \mathrm{C}\end{array}$} & \multirow{2}{*}{$\begin{array}{l}\text { CELL } \\
T / C\end{array}$} & \multirow{2}{*}{$\begin{array}{l}\text { TEST } \\
\text { DIR. } \\
\text { INIT }\end{array}$} \\
\hline & $\begin{array}{c}T_{1} \\
15 \mathrm{~s} \\
\end{array}$ & $\begin{array}{r}T_{2} \\
30 \mathrm{~s} \\
\end{array}$ & $\begin{array}{r}T_{3} \\
45 \mathrm{~s} \\
\end{array}$ & $\begin{array}{r}T_{4} \\
60 \mathrm{~s} \\
\end{array}$ & $\begin{array}{r}T_{5} \\
75 \mathrm{~s} \\
\end{array}$ & $\begin{array}{r}T_{6} \\
90 \mathrm{~s} \\
\end{array}$ & $\begin{array}{r}{ }^{\top} \mathrm{T} \\
105 \mathrm{~s}\end{array}$ & $\begin{array}{r}T_{8} \\
120 \mathrm{~s} \\
\end{array}$ & $\begin{array}{r}T_{0} \\
870 \mathrm{~s} \\
\end{array}$ & $\begin{array}{r}T_{10} \\
900 \mathrm{~s} \\
\end{array}$ & & & & & \\
\hline \multicolumn{16}{|l|}{ WEC 1} \\
\hline \multicolumn{16}{|l|}{ SIG 1} \\
\hline \multicolumn{16}{|l|}{ WEC 2} \\
\hline SIG 2 & & & & & & & & & & & & & & & 产 \\
\hline HEC 3 & & & & & & & & & & & & & & & $\overrightarrow{\overrightarrow{3}}$ \\
\hline \multicolumn{16}{|l|}{ SIG 3} \\
\hline \multicolumn{16}{|l|}{ WEC 4} \\
\hline SIG 4 & & & & & & & & & & & & & & & ₹ \\
\hline WEC 5 & & & & & & & & & & & & & & & 0 \\
\hline SIG 5 & . & & & & & & & & & & & & & & \\
\hline
\end{tabular}

웅
녕 
TEST PROCEDURE FOR MEASUREMENT OF PERFORMANCE VS TEMPERATURE WHITTAKER CELL

9.109 DATA RECORD SHEET 441

A.

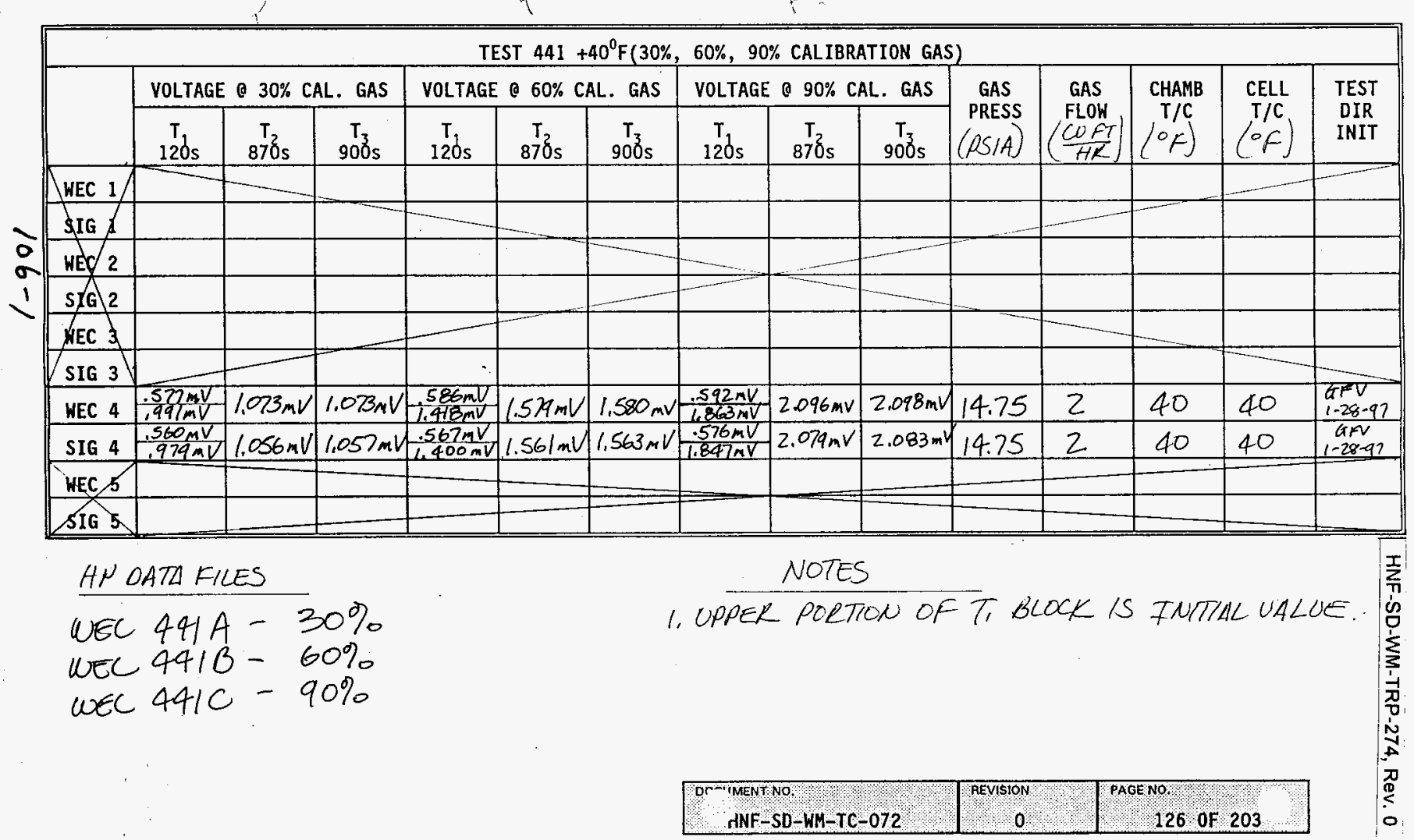




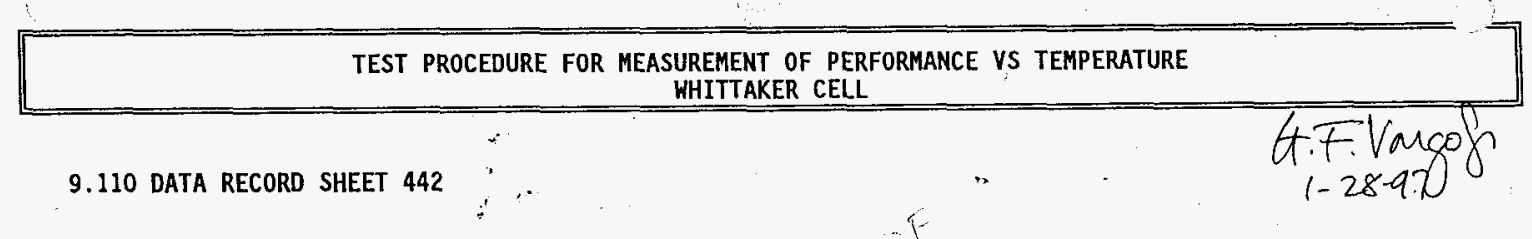

SUREMENT OF PERFORMANCE VS TEMPERATURE

TEST $4420+40^{\circ} \mathrm{F}$ ( $15 T$. $100 \%$ CALIBRATION RATE TEST)

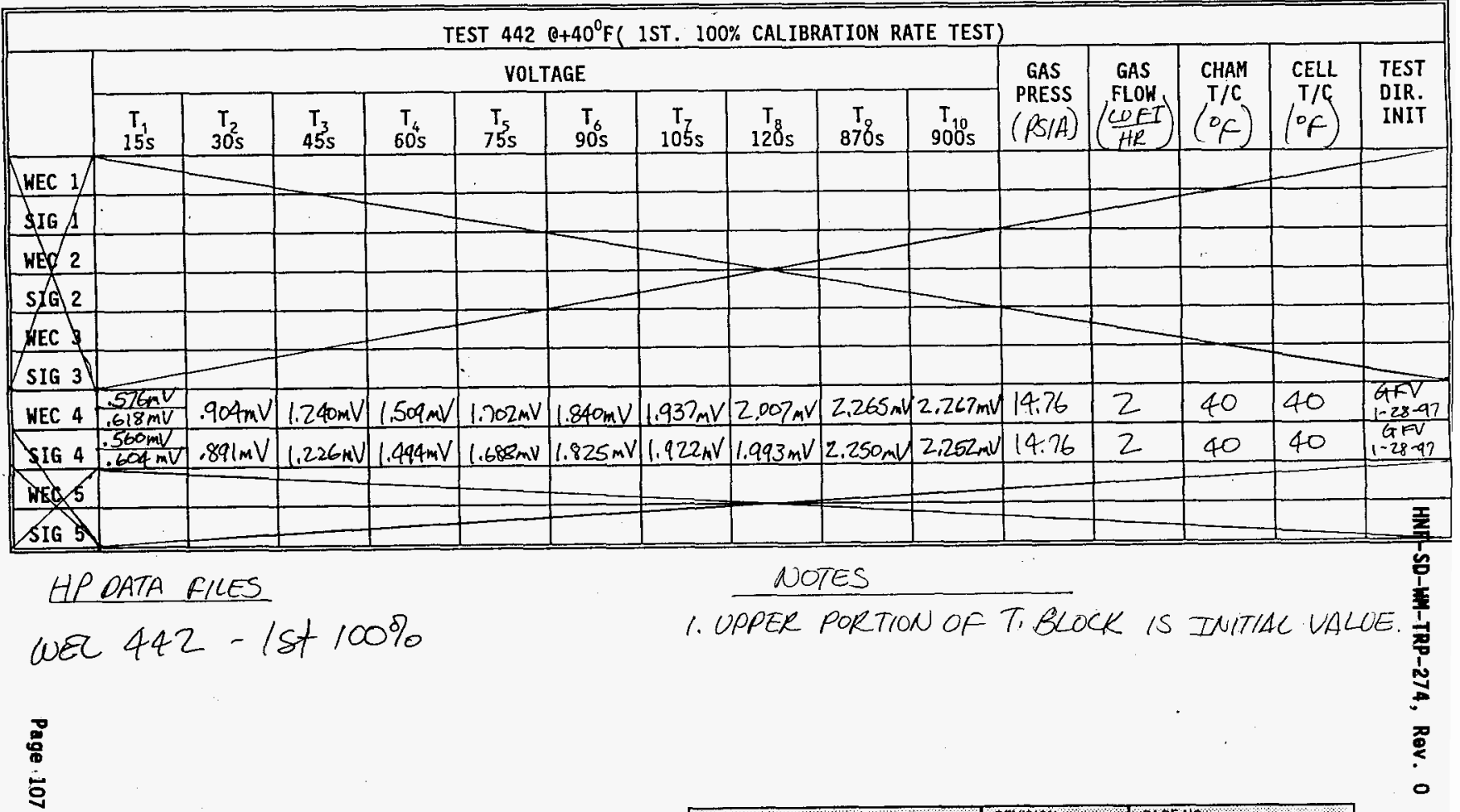


TEST PROCEDURE FOR MEASUREMENT OF PERFORMANCE VS TEMPERATURE

WHITTAKER CELL

9.111 DATA RECORD SHEET 443

;

$+2$

A.F.Varcot

$1-28.96$

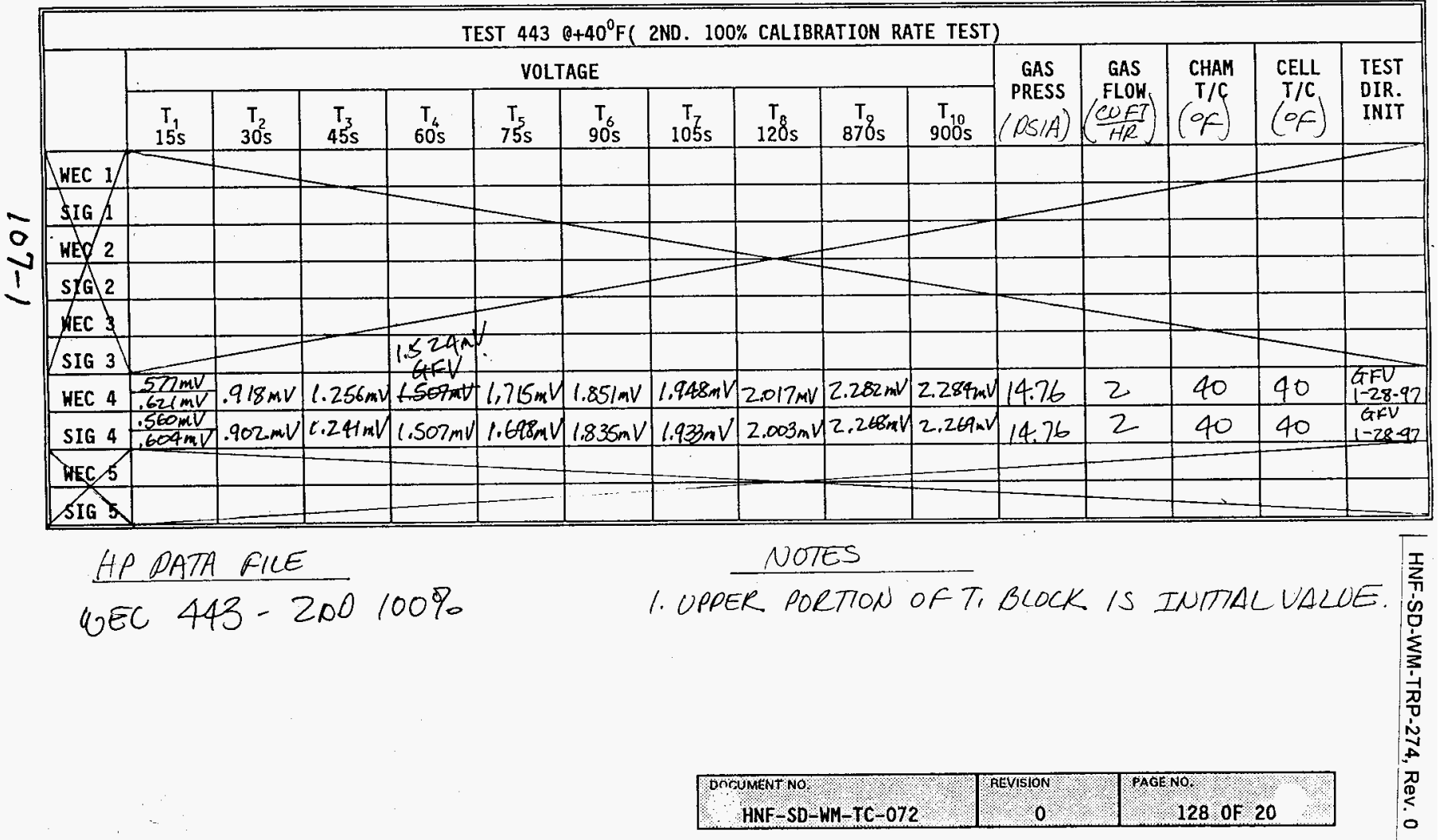


TEST PROCEDURE FOR MEASUREMENT OF PERFORMANCE VS TEMPERATURE WHITTAKER CELL

9.112 DATA RECORD SHEET 444

F

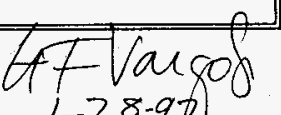

$1-28-97$

\begin{tabular}{|c|c|c|c|c|c|c|c|c|c|c|c|c|c|c|c|}
\hline \multicolumn{16}{|c|}{ TEST $4440+40^{\circ} \mathrm{F}$ (3RD. $100 \%$ CALIBRATION RATE TEST) } \\
\hline & \multicolumn{10}{|c|}{ VOLTAGE } & \multirow{2}{*}{$\begin{array}{c}\text { GAS } \\
\text { PRESS } \\
(p S \mid A)\end{array}$} & \multirow{2}{*}{$\begin{array}{c}\text { GAS } \\
\text { FLOW } \\
\left(\frac{C U \& 7}{H E}\right)\end{array}$} & \multirow{2}{*}{$\begin{array}{l}\text { CHAM } \\
\mathrm{T} / \mathrm{C} \\
(\%)\end{array}$} & \multirow{2}{*}{$\begin{array}{l}\text { CELL } \\
\mathrm{T} / \mathrm{C} \\
(\%)\end{array}$} & \multirow{2}{*}{$\begin{array}{l}\text { TEST } \\
\text { DIR. } \\
\text { INIT } \\
\end{array}$} \\
\hline & $\begin{array}{r}T_{1} \\
15 \mathrm{~s} \\
\end{array}$ & $\begin{array}{r}T_{2} \\
30 s \\
\end{array}$ & $\begin{array}{r}T_{3} \\
45 s \\
\end{array}$ & $\begin{array}{c}T_{4} \\
60 \mathrm{~s} \\
\end{array}$ & $\begin{array}{r}\mathrm{T}_{5} \\
75 \mathrm{~s} \\
\end{array}$ & $\begin{array}{r}T_{6} \\
90 \mathrm{~s} \\
\end{array}$ & ${ }_{105 \mathrm{~s}}^{\mathrm{T}}$ & $\begin{array}{c}\mathrm{T} \\
120 \mathrm{~s} \\
\end{array}$ & $\begin{array}{r}\mathrm{T} \\
870 \mathrm{~s} \\
\end{array}$ & $\begin{array}{r}\mathrm{T}_{10} \\
900 \mathrm{~s} \\
\end{array}$ & & & & & \\
\hline \multicolumn{16}{|l|}{ WEC $1 /$} \\
\hline SIG & & & & & & & & & & & & & & & $\frac{1}{2}$ \\
\hline WEC 2 & & & & & & & & & & & & & & & 孚 \\
\hline SIG 2 & & & & & & & & & 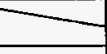 & & & & & & No \\
\hline$\sqrt{E C} 3$ & $\cdot$ & & & & & & & & & & & & & & + \\
\hline SIG 3 & & & & & $\because$ & & & & & & & & & & \\
\hline WEC 4 & $\frac{.559 \mathrm{mV}}{.609 \mathrm{mV}}$ & $.912 \mathrm{mv}$ & $1.254 \mathrm{kV}$ & $1.525 \mathrm{mV}$ & $1.717 \mathrm{mV}$ & $1.856 \mathrm{mV}$ & $1.953 \mathrm{mV}$ & $2.023 \mathrm{MV}$ & $2.28 \mathrm{mV}$ & $2.294 \mathrm{~m}$ & 14.78 & 2 & 40 & 40 & $\begin{array}{l}6 f V \\
1-28-9\end{array}$ \\
\hline SIG 4 & $\begin{array}{l}.54 \mathrm{mV} \\
.594 \mathrm{VV}\end{array}$ & $.898 \mathrm{mV}$ & $1.238 \mathrm{mV}$ & $1.509 \mathrm{mV}$ & $1.701 \mathrm{mV}$ & $1.839 \mathrm{mV}$ & $1.937 \mathrm{mV}$ & $2007 \mathrm{mV}$ & $2.278 \mathrm{rav}$ & $2.279 \mathrm{mV}$ & 14.78 & 2 & 40 & 40 & $\begin{array}{c}6 f v \\
1-28.97\end{array}$ \\
\hline WEC 5 & & & & & & & & & & & & & & & \\
\hline SIG 5 & & & & - & & & & & & & & & & & \\
\hline
\end{tabular}

HP DATA FILE

WEC $444-3 R 100 \%$

\section{NOTES}

1. UPPEK PORTION OF TI BLOCK IS IUTTLL VALUE

\section{ڤัँ}




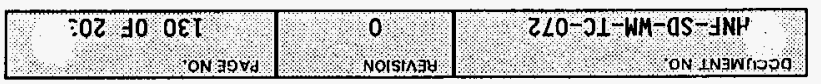

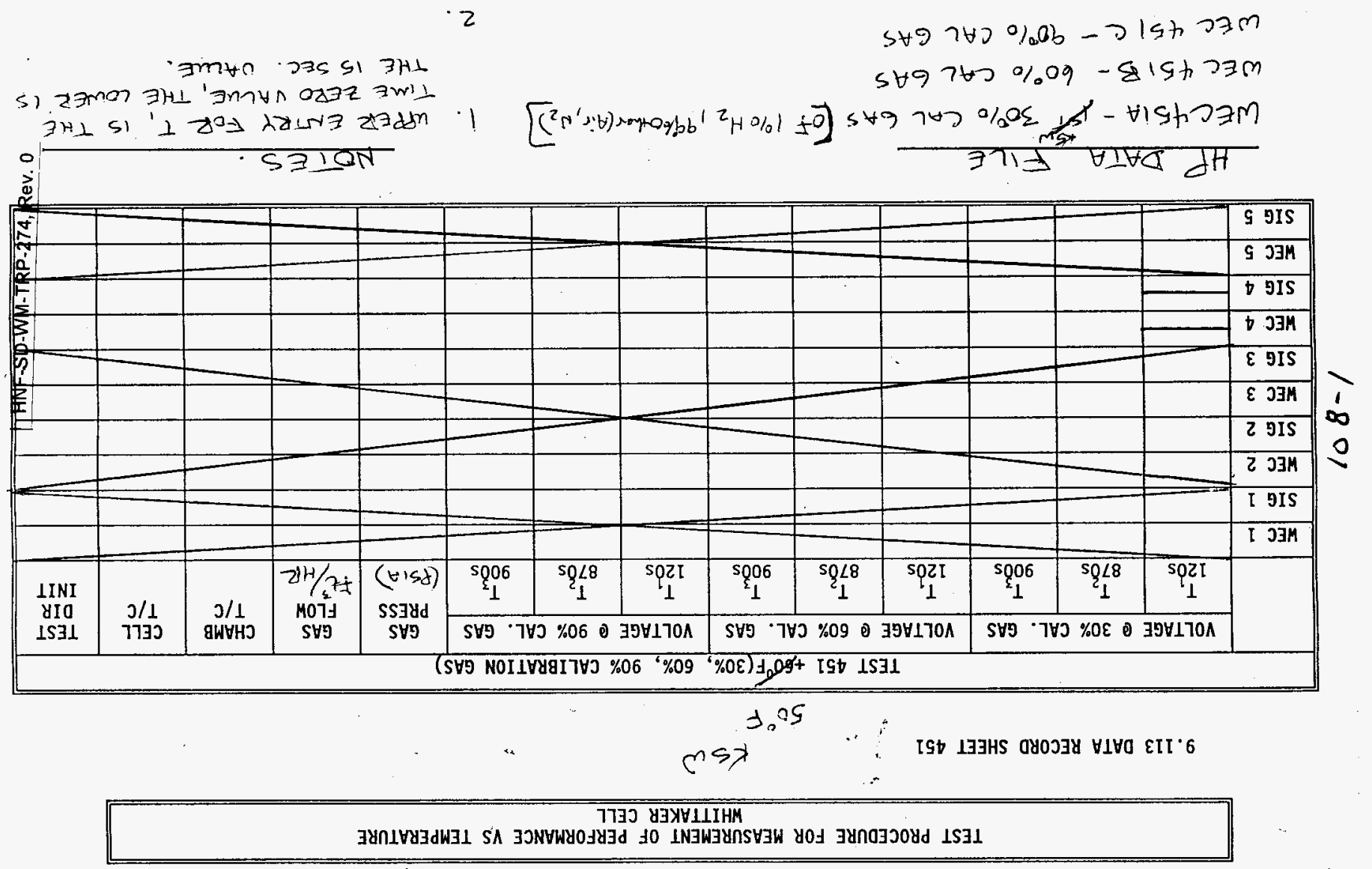




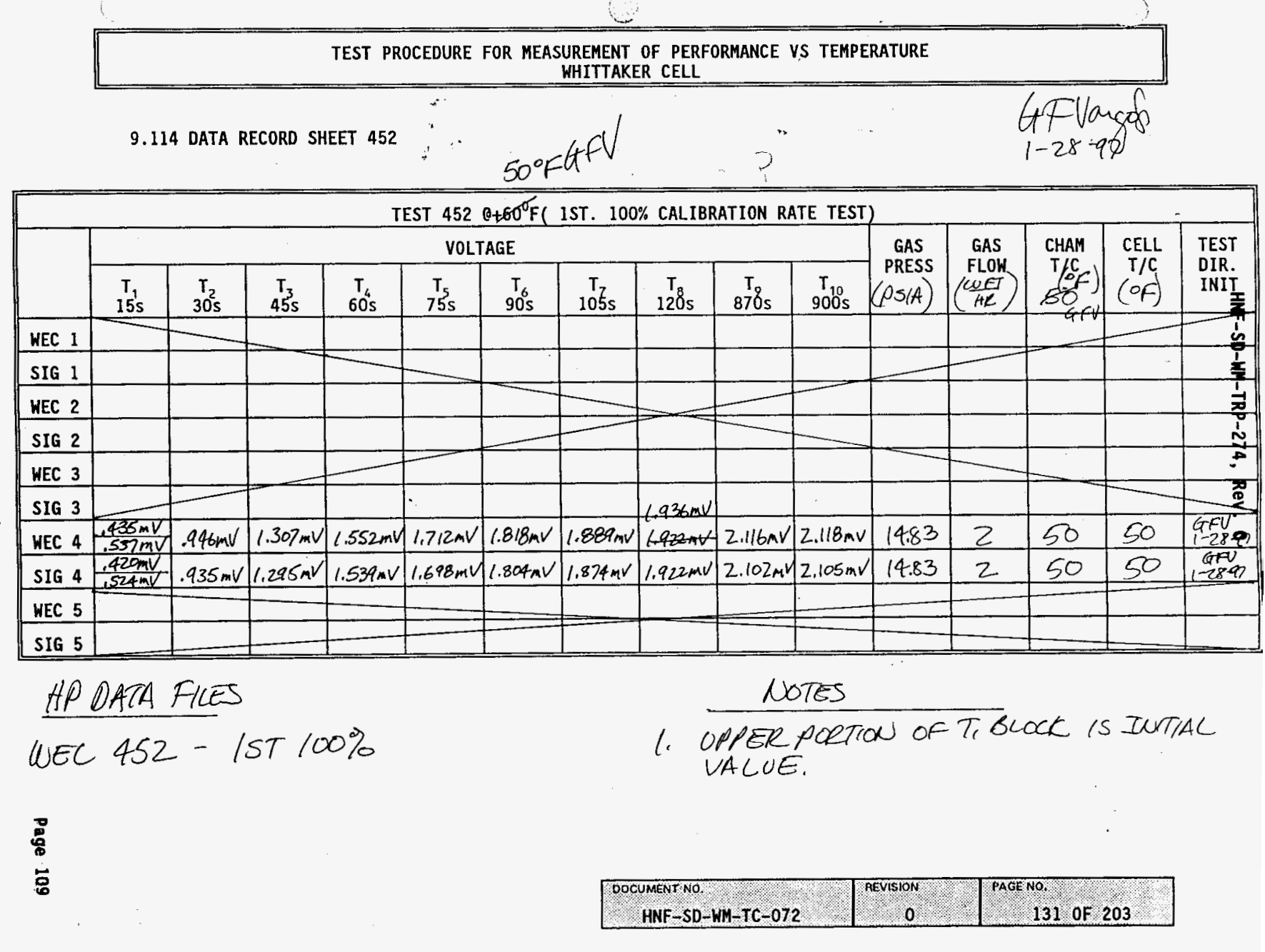


TEST PROCEDURE FOR MEASUREMENT OF PERFORMANCE VS TEMPERATURE

WHITTAKER CELL

\subsection{DATA RECORD SHEET 453}

TEST $4530+60^{\circ} \mathrm{F}$ ( 2ND. $100 \%$ CALIBRATION RATE TEST)

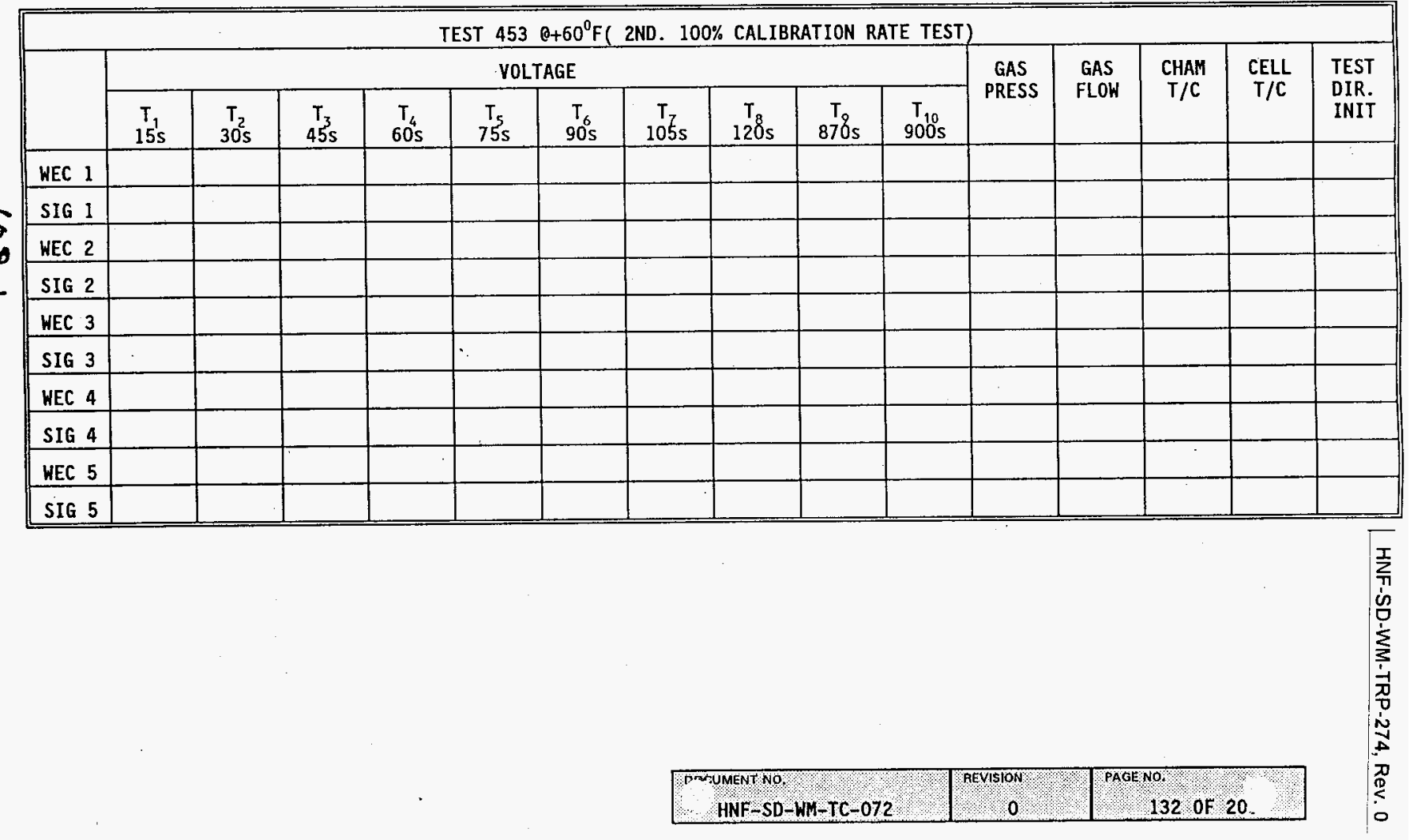




\subsection{DATA RECORD SHEET 384}

TEST $3840+120^{\circ} \mathrm{F}$ (3RD. $100 \%$ CALIBRATION RATE TEST)

\begin{tabular}{|c|c|c|c|c|c|c|c|c|c|c|c|c|c|c|c|}
\hline & \multicolumn{10}{|c|}{ VOLTAGE } & \multirow{2}{*}{$\begin{array}{c}\text { GAS } \\
\text { PRESS }\end{array}$} & \multirow{2}{*}{$\begin{array}{c}\text { GAS } \\
\text { FLOW }\end{array}$} & \multirow{2}{*}{$\begin{array}{l}\text { CHAM } \\
\mathrm{T} / \mathrm{C}\end{array}$} & \multirow{2}{*}{$\begin{array}{c}\text { CELL } \\
T / C\end{array}$} & \multirow{2}{*}{$\begin{array}{l}\text { TEST } \\
\text { DIR. } \\
\text { INIT }\end{array}$} \\
\hline & $\begin{array}{r}T_{1} \\
15 \mathrm{~s} \\
\end{array}$ & $\begin{array}{r}\mathrm{T}_{2} \\
30 \mathrm{~s} \\
\end{array}$ & $\begin{array}{r}T_{3} \\
45 \mathrm{~s} \\
\end{array}$ & $\begin{array}{r}T_{6} \\
60 \mathrm{~s}\end{array}$ & $\begin{array}{r}T_{5} \\
75 s \\
\end{array}$ & $\begin{array}{r}T_{6} \\
90 \mathrm{~s} \\
\end{array}$ & ${ }_{105 \mathrm{~s}}^{\mathrm{T}}$ & $\begin{array}{c}\mathrm{T}_{\mathrm{S}} \\
120 \mathrm{~s}\end{array}$ & $\begin{array}{c}\mathrm{T} \\
870 \mathrm{~s}\end{array}$ & $\begin{array}{c}\mathrm{T}_{10} \\
9000 \mathrm{~s}\end{array}$ & & & & & \\
\hline \multicolumn{16}{|l|}{ WEC 1} \\
\hline \multicolumn{16}{|l|}{ SIG 1} \\
\hline WEC 2 & & & & & & & & & & & & & & & 芧 \\
\hline SIG 2 & & & & & & & & & & & & & & & 扸 \\
\hline \multicolumn{16}{|l|}{ WEC 3} \\
\hline SIG 3 & & & & & & & & & & & & & & & 궁 \\
\hline \multicolumn{16}{|l|}{ WEC 4} \\
\hline \multicolumn{16}{|l|}{ SIG 4} \\
\hline WEC 5 & & & & & & & & & & & & & & & 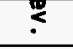 \\
\hline SIG 5 & & & & & & & & & & & & & & & 0 \\
\hline
\end{tabular}




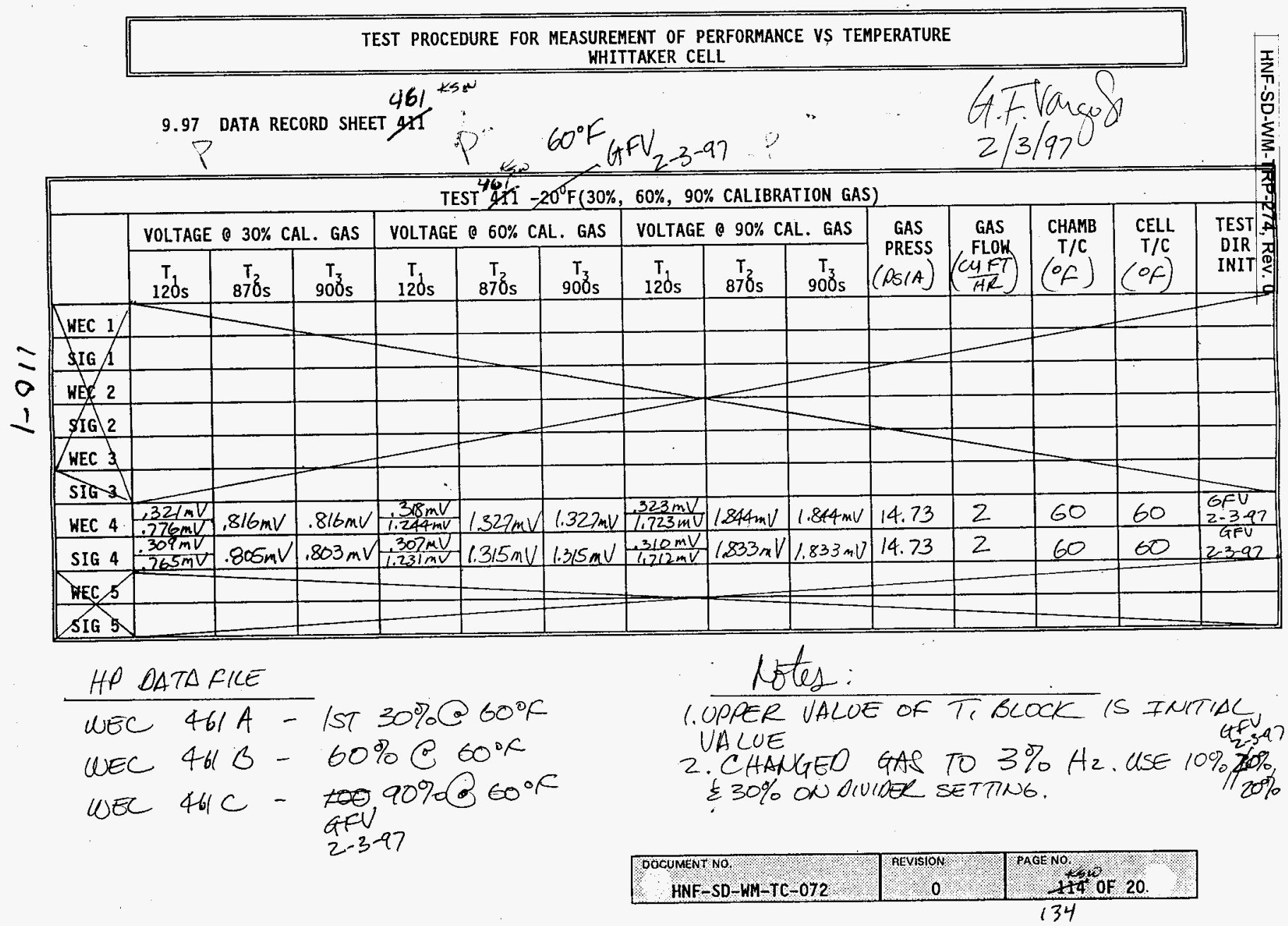


TEST PROCEDURE FOR MEASUREMENT OF PERFORMANCE VS TEMPERATURE WHITAKER CELL

9.118 DATA RECORD SHEET 462

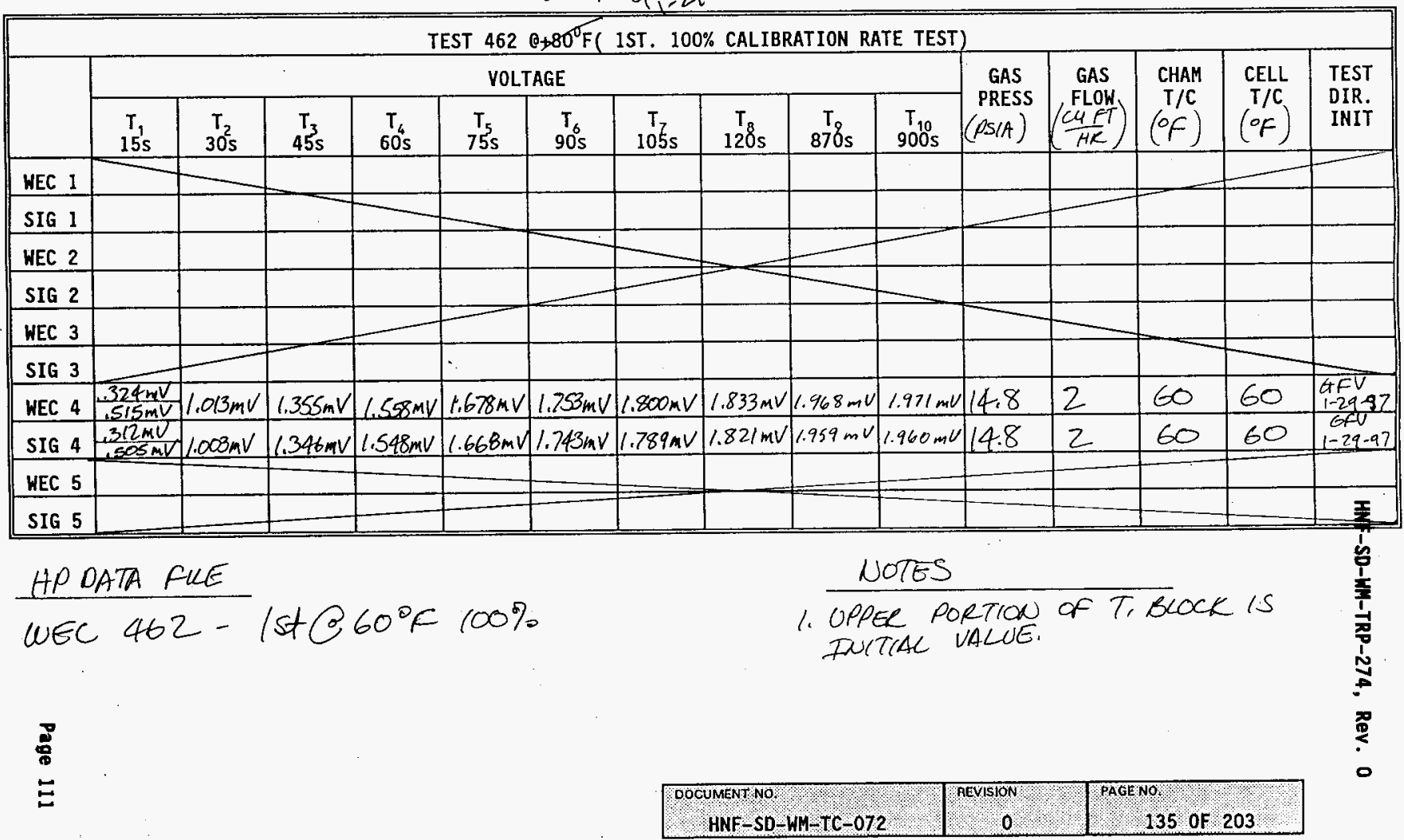


TEST PROCEDURE FOR MEASUREMENT OF PERFORMANCE VS TEMPERATURE

WHITTAKER CELL

\subsection{DATA RECORD SHEET 463}

TEST $4630+80^{\circ} \mathrm{F}$ ( 2ND. $100 \%$ CALIBRATION RATE TEST)

\section{VOLTAGE}

\begin{tabular}{|c|c|c|c|c|c|c|c|c|c|c|}
\hline & \multicolumn{10}{|c|}{ VOLTAGE } \\
\hline & $\begin{array}{r}T_{1} \\
15 \mathrm{~s} \\
\end{array}$ & $\begin{array}{r}\mathrm{T}_{2} \\
30 \mathrm{~s} \\
\end{array}$ & $\begin{array}{r}T_{3} \\
45 \mathrm{~s} \\
\end{array}$ & $\begin{array}{r}T_{4} \\
60 \mathrm{~s} \\
\end{array}$ & $\begin{array}{r}T_{5} \\
75 \mathrm{~s} \\
\end{array}$ & $\begin{array}{r}\mathrm{T}_{6} \\
90 \mathrm{~s} \\
\end{array}$ & $\begin{array}{c}\mathrm{T} \\
105 \mathrm{~s} \\
\end{array}$ & $\begin{array}{r}T_{8} \\
120 s \\
\end{array}$ & $\begin{array}{r}T \\
87 \% \text { s } \\
\end{array}$ & $\begin{array}{r}T_{10} \\
900 \mathrm{~s}\end{array}$ \\
\hline WEC 1 & & & & & & & & & & \\
\hline SIG 1 & & & & & & & & & & \\
\hline WEC 2 & & & & & & & & & & \\
\hline SIG 2 & & & & & & & & & & \\
\hline HEC 3 & & & & & & & & & & \\
\hline SIG 3 & & & & & & & & & & \\
\hline WEC 4 & & & & & & & & & & \\
\hline SIG 4 & & & & & & & & & & \\
\hline WEC 5 & & & & & & & & & & \\
\hline SIG 5 & & & & & & & & & & \\
\hline
\end{tabular}

\begin{tabular}{c|c|c|c|} 
GAS \\
PRESS
\end{tabular}

\begin{tabular}{|c|c|}
\hline GAS \\
FLOW
\end{tabular}

CHAM
T/C

CELL

TEST

DIR.

INIT 


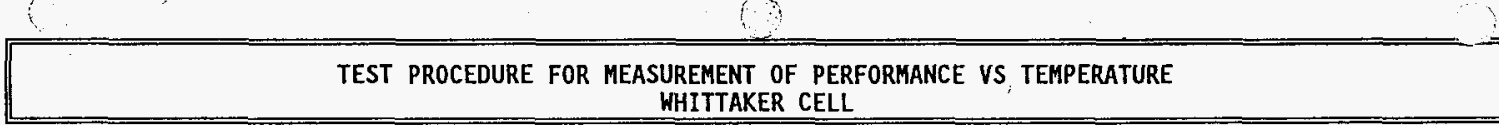

\section{WHITTAKER CELL}

\subsection{DATA RECORD SHEET 464}

TEST $4640+80^{\circ} \mathrm{F}$ ( 3RD. 100\% CALIBRATION RATE TEST)

\begin{tabular}{|c|c|c|c|c|c|c|c|c|c|c|c|c|c|c|c|}
\hline & \multicolumn{10}{|c|}{ VOLTAGE } & \multirow{2}{*}{$\begin{array}{c}\text { GAS } \\
\text { PRESS }\end{array}$} & \multirow{2}{*}{$\begin{array}{l}\text { GAS } \\
\text { FLOH }\end{array}$} & \multirow{2}{*}{$\begin{array}{l}\text { CHAM } \\
\mathrm{T} / \mathrm{C}\end{array}$} & \multirow{2}{*}{$\begin{array}{l}\text { CELL } \\
\text { T/C }\end{array}$} & \multirow{2}{*}{$\begin{array}{l}\text { TEST } \\
\text { DIR. } \\
\text { INI }\end{array}$} \\
\hline & $\begin{array}{r}T \\
155 \\
\end{array}$ & $\begin{array}{r}\mathrm{T}_{2} \\
30 \mathrm{~s} \\
\end{array}$ & $\begin{array}{r}T_{3} \\
455 \\
\end{array}$ & $\begin{array}{r}T_{4} \\
60 \mathrm{~s}\end{array}$ & $\begin{array}{r}T_{5} \\
75 \mathrm{~s} \\
\end{array}$ & $\begin{array}{c}T_{6} \\
90 \mathrm{~s}\end{array}$ & $\begin{array}{c}T_{7} \\
105 \mathrm{~s}\end{array}$ & $\begin{array}{c}\mathrm{T}_{8} \\
120 \mathrm{~s}\end{array}$ & $\begin{array}{c}T^{\top} \mathrm{s}^{2} \\
870 \mathrm{~s}\end{array}$ & $\begin{array}{c}T_{10} \\
9000 \mathrm{~s}\end{array}$ & & & & & \\
\hline \multicolumn{16}{|l|}{ HEC 1} \\
\hline \multicolumn{16}{|l|}{ SIG 1} \\
\hline \multicolumn{16}{|l|}{ WEC 2} \\
\hline \multicolumn{16}{|l|}{ SIG 2} \\
\hline \multicolumn{16}{|l|}{ HEC 3} \\
\hline \multicolumn{16}{|l|}{ SIG 3} \\
\hline \multicolumn{16}{|l|}{ WEC 4} \\
\hline SIG 4 & & & & & & & & & & & & & & & 要 \\
\hline WEC 5 & & & & & & & & & & & & & & & 0 \\
\hline SIG 5 & & & & & & & & & & & & & & & \\
\hline
\end{tabular}

$B$
N
N 


\section{TEST PROCEDURE FOR MEASUREMENT OF PERFORMANCE VS TEMPERATURE}

WHITTAKER CELL

\subsection{DATA RECORD SHEET 471}

$$
70^{\circ} \mathrm{F}
$$

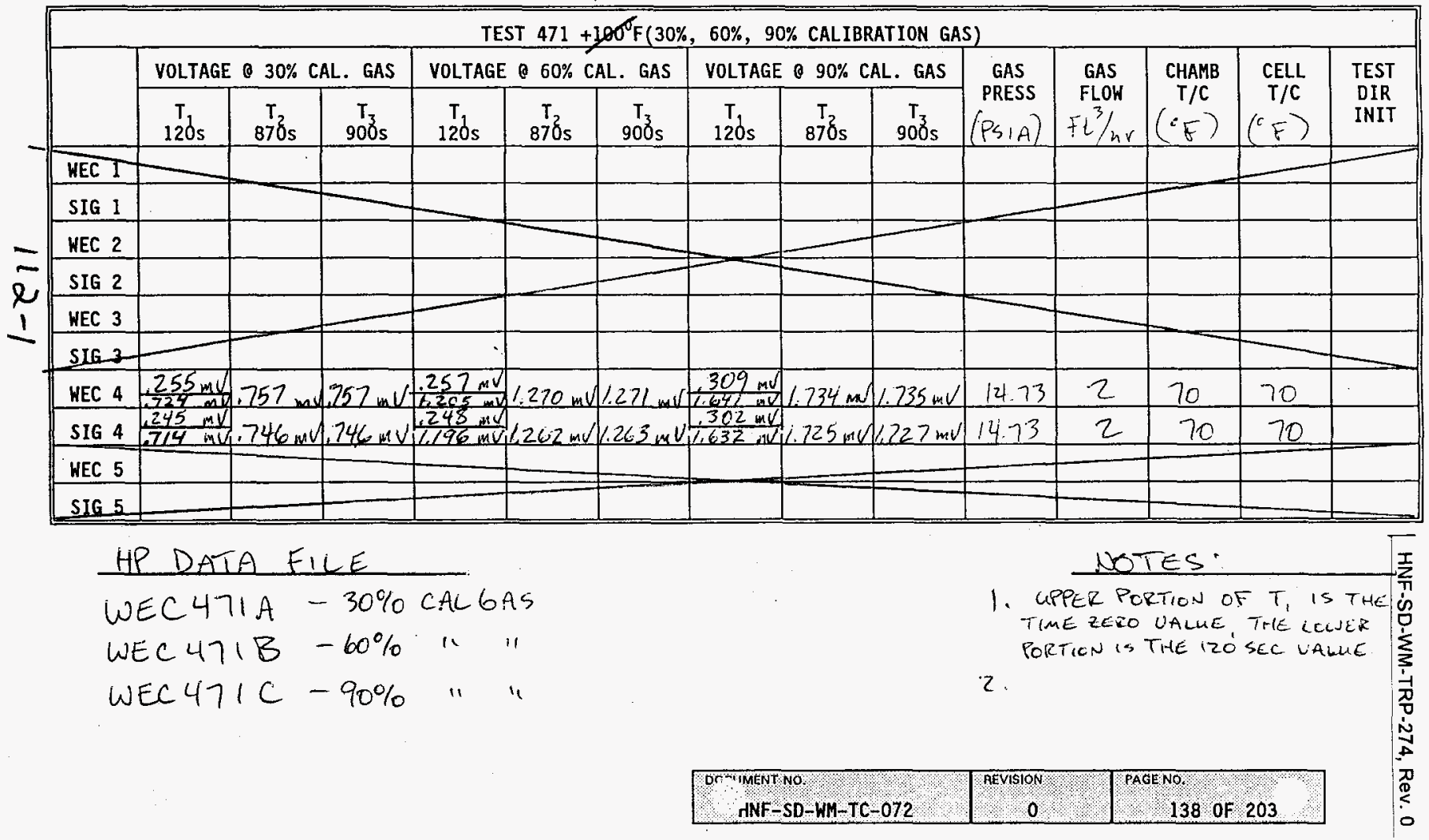


TEST PROCEDURE FOR MEASUREMENT OF PERFORMANCE VS TEMPERATURE WHITTAKER CELL

\subsection{DATA RECORD SHEET 472}

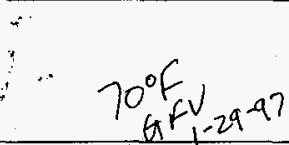

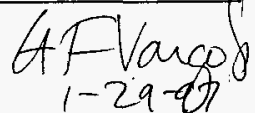

\begin{tabular}{|c|c|c|c|c|c|c|c|c|c|c|c|c|c|c|c|}
\hline & & & & & EST 472 & $\theta+100^{\circ} \mathrm{FC}$ & $1 \mathrm{ST} .10$ & $0 \%$ CALIB & RATION R & ATE TEST & & & & & \\
\hline & & & & & VOLT & TAGE & & & & & GAS & GAS & CHAM & CELL & TEST \\
\hline & $\begin{array}{r}T_{1} \\
15 \mathrm{~s} \\
\end{array}$ & $\begin{array}{r}\mathrm{T}_{2} \\
30 \mathrm{~s} \\
\end{array}$ & $\begin{array}{r}T_{3} \\
45 \mathrm{~s} \\
\end{array}$ & $\begin{array}{r}T_{4} \\
60 \mathrm{~s} \\
\end{array}$ & $\begin{array}{r}T \\
75 s \\
\end{array}$ & $\begin{array}{r}T_{6} \\
90 s \\
\end{array}$ & $\begin{array}{c}\mathrm{T}_{7} \\
105 \mathrm{~s} \\
\end{array}$ & $\begin{array}{c}T_{8} \\
120 \mathrm{~s} \\
\end{array}$ & $\begin{array}{c}T_{0} \\
870 \mathrm{~s} \\
\end{array}$ & $\begin{array}{r}T_{10} \\
900 \mathrm{~s}\end{array}$ & $(P S A)$ & $\left(\frac{C U F T}{H R}\right)$ & $(o f)$ & $\left({ }^{\circ} \mathrm{F}\right)$ & INIT \\
\hline HEC 1 & & & & & & & & & & & & & & $\longrightarrow$ & \\
\hline SIG 1 & & & & & & & & & & & & & & & \\
\hline HEC 2 & & & & & & & & & - & & & & & & \\
\hline SIG 2 & & & & & & & & & 5 & 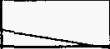 & & & & & \\
\hline WEC 3 & & & & $=$ & & & & & & & & +2 & & & \\
\hline SIG 3 & & & & & 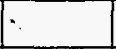 & & & & & & & & & 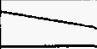 & \\
\hline WEC 4 & $\begin{array}{r}.250 \mathrm{mV} \\
.580 \mathrm{mV}\end{array}$ & $1,102 \mathrm{mV}$ & $1,389 \mathrm{mV}$ & $1.541 \mathrm{mV}$ & $1.625 \mathrm{mb}$ & $1.675 \mathrm{mV}$ & $1.707 \mathrm{mV}$ & $1.730 \mathrm{mV}$ & $1.84 \mathrm{mV}$ & $1.843 \mathrm{mV}$ & 14.77 & 2 & 20 & 20 & $\begin{array}{l}6 F U \\
1-29-9)\end{array}$ \\
\hline SIG 4 & $\frac{.242 \mathrm{nV}}{522 \mathrm{mV}}$ & $-1.094 \times 4$ & $1.380 \mathrm{nV}$ & $1.532 \mathrm{mV}$ & $1.607 \mathrm{mV}$ & $1.667 \mathrm{mV}$ & $1.697 \mathrm{mV}$ & $1.721 \mathrm{mv}$ & $1.832 \mathrm{mV}$ & $1.834 \mathrm{nV}$ & 14.77 & 2 & 70 & $x$ & 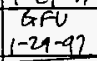 \\
\hline WEC 5 & & & & & & & & & & - & & & & & \\
\hline SIG 5 & & & & & & & & & & & & & & & \\
\hline
\end{tabular}

HP DATA FILE

WEC $472-13 T 100 \%$ Q $70^{\circ} \mathrm{K}$
NOTES

1. OPPER PORTION OF T, BLOCK IS FUTTAL UALUE.

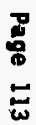


TEST PROCEDURE FOR MEASUREMENT OF PERFORMANCE VS TEMPERATURE

WHITTAKER CELL

9.123 DATA RECORD SHEET 473

TEST $4730+100^{\circ} \mathrm{F}$ ( 2ND. 100\% CALIBRATION RATE TEST)

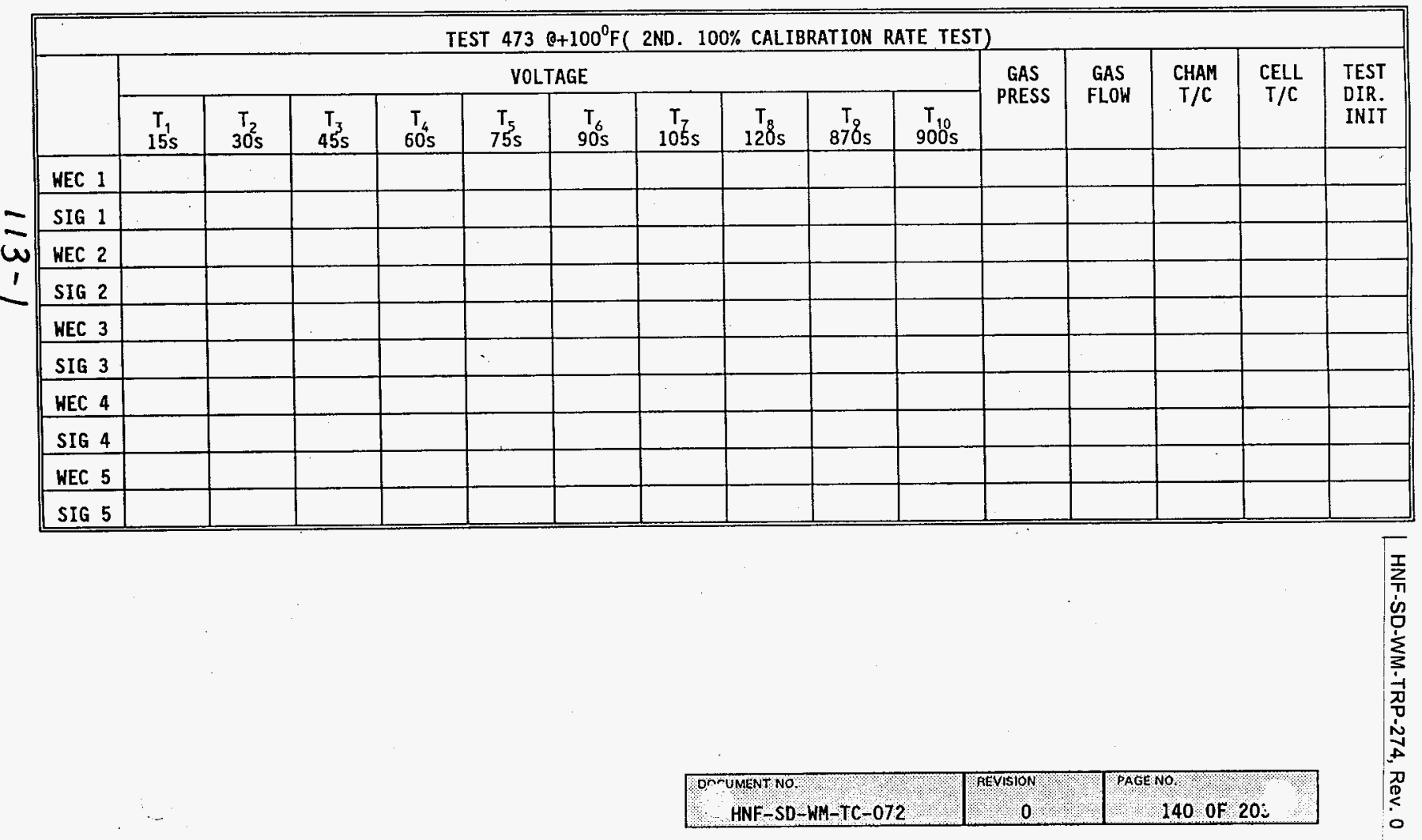


TEST PROCEDURE FOR MEASUREMENT OF PERFORMANCE VS TEMPERATURE

WHITTAKER CELL

9.124 DATA RECORD SHEET $474, \frac{1}{i}, \cdots$

\begin{tabular}{|c|c|c|c|c|c|c|c|c|c|c|c|c|c|c|c|}
\hline \multicolumn{16}{|c|}{ TEST $474 \theta+100^{\circ} \mathrm{F}$ (3RD. $100 \%$ CALIBRATION RATE TEST) } \\
\hline & \multicolumn{10}{|c|}{ VOLTAGE } & \multirow{2}{*}{$\begin{array}{c}\text { GAS } \\
\text { PRESS }\end{array}$} & \multirow{2}{*}{$\begin{array}{l}\text { GAS } \\
\text { FLOW }\end{array}$} & \multirow{2}{*}{$\begin{array}{c}\text { CHAM } \\
T / C\end{array}$} & \multirow{2}{*}{$\begin{array}{c}\text { CELL } \\
\mathrm{T} / \mathrm{C}\end{array}$} & \multirow{2}{*}{$\begin{array}{l}\text { TEST } \\
\text { DIR. } \\
\text { INIT }\end{array}$} \\
\hline & $\begin{array}{c}T_{1} \\
15 \mathrm{~s} \\
\end{array}$ & $\begin{array}{r}\mathrm{T}_{2} \\
30 \mathrm{~s} \\
\end{array}$ & $\begin{array}{r}T_{3} \\
45 \mathrm{~s} \\
\end{array}$ & $\begin{array}{r}\mathrm{T}_{4} \\
60 \mathrm{~s} \\
\end{array}$ & $\begin{array}{r}T_{5} \\
75 \mathrm{~s} \\
\end{array}$ & $\begin{array}{c}\mathrm{T}_{6} \\
90 \mathrm{~s} \\
\end{array}$ & ${ }_{105 \mathrm{~s}}$ & $\begin{array}{c}T_{8} \\
120 \mathrm{~s} \\
\end{array}$ & $\begin{array}{c}\mathrm{T}_{8} \\
87 \mathrm{O}_{\mathrm{s}}\end{array}$ & $\begin{array}{c}T_{10} \\
9005\end{array}$ & & & & & \\
\hline \multicolumn{16}{|l|}{ WEC 1} \\
\hline \multicolumn{16}{|l|}{ SIG 1} \\
\hline \multicolumn{16}{|l|}{ WEC 2} \\
\hline \multicolumn{16}{|l|}{ SIG 2} \\
\hline \multicolumn{16}{|l|}{ WEC 3} \\
\hline \multicolumn{16}{|l|}{ SIG 3} \\
\hline \multicolumn{16}{|l|}{ WEC 4} \\
\hline SIG 4 & & & & & & & & & & & & & & & 若 \\
\hline WEC 5 & & & & & & & & & & & & & & & 웅 \\
\hline SIG 5 & & & & & & & & & & & & & & & \\
\hline
\end{tabular}

号
号 
TEST PROCEDURE FOR MEASUREMENT OF PERFORMANCE VS TEMPERATURE

WHITTAKER CELL

9.125 DATA RECORD SHEET 481

TEST $481+120^{\circ} \mathrm{F}(30 \%, 60 \%, 90 \%$ CALIBRATION GAS $)$

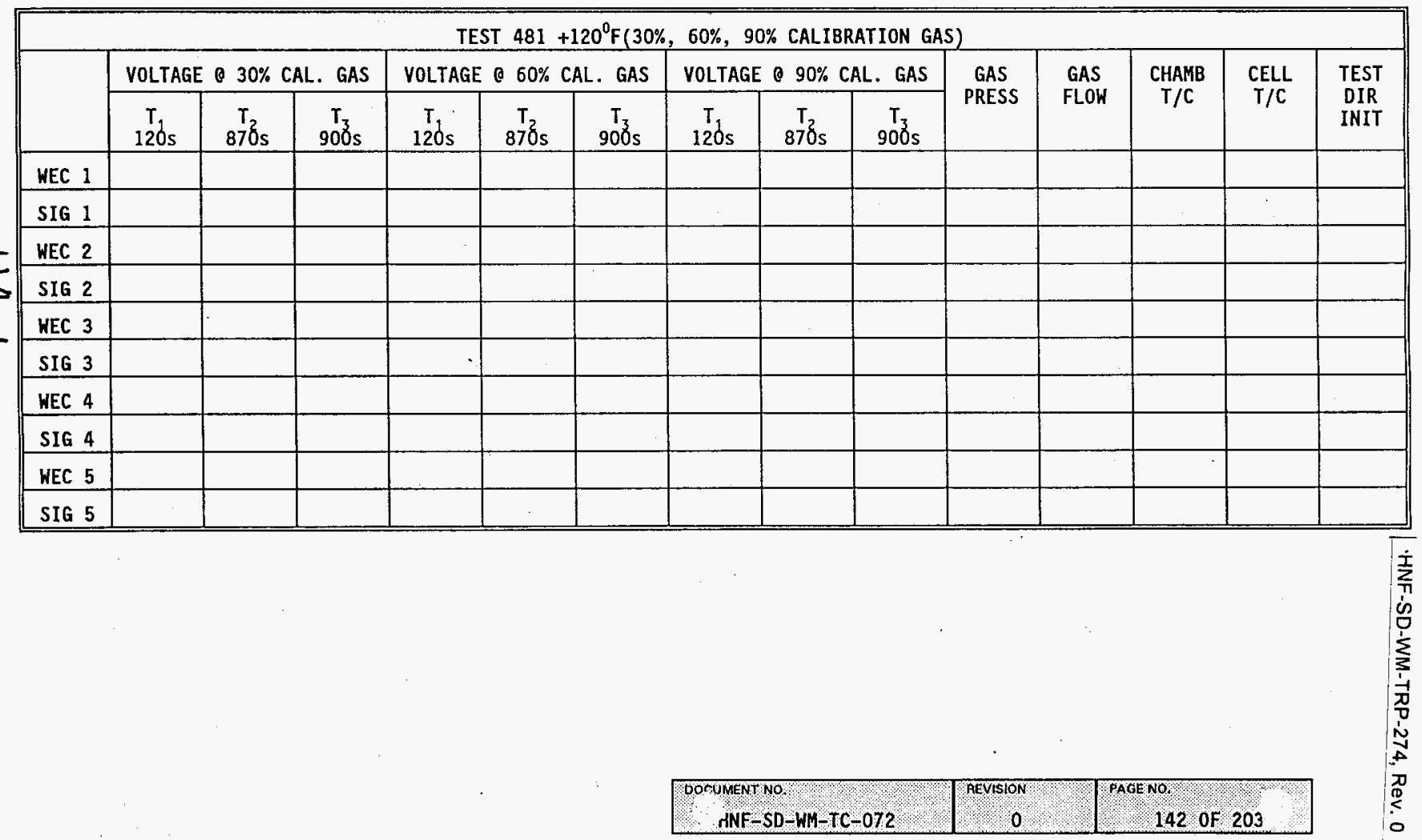


TEST PROCEDURE FOR MEASUREMENT OF PERFORMANCE VS TEMPERATURE WHITTAKER CELL

9.126 DATA RECORD SHEET 482

$$
\begin{array}{rl}
80^{\circ} \mathrm{F} & \mathrm{Ks} / / 3.197
\end{array}
$$

TEST $4820+120^{\circ} \mathrm{F}$ ( $15 T$. $100 \%$ CALIBRATION RATE TEST)

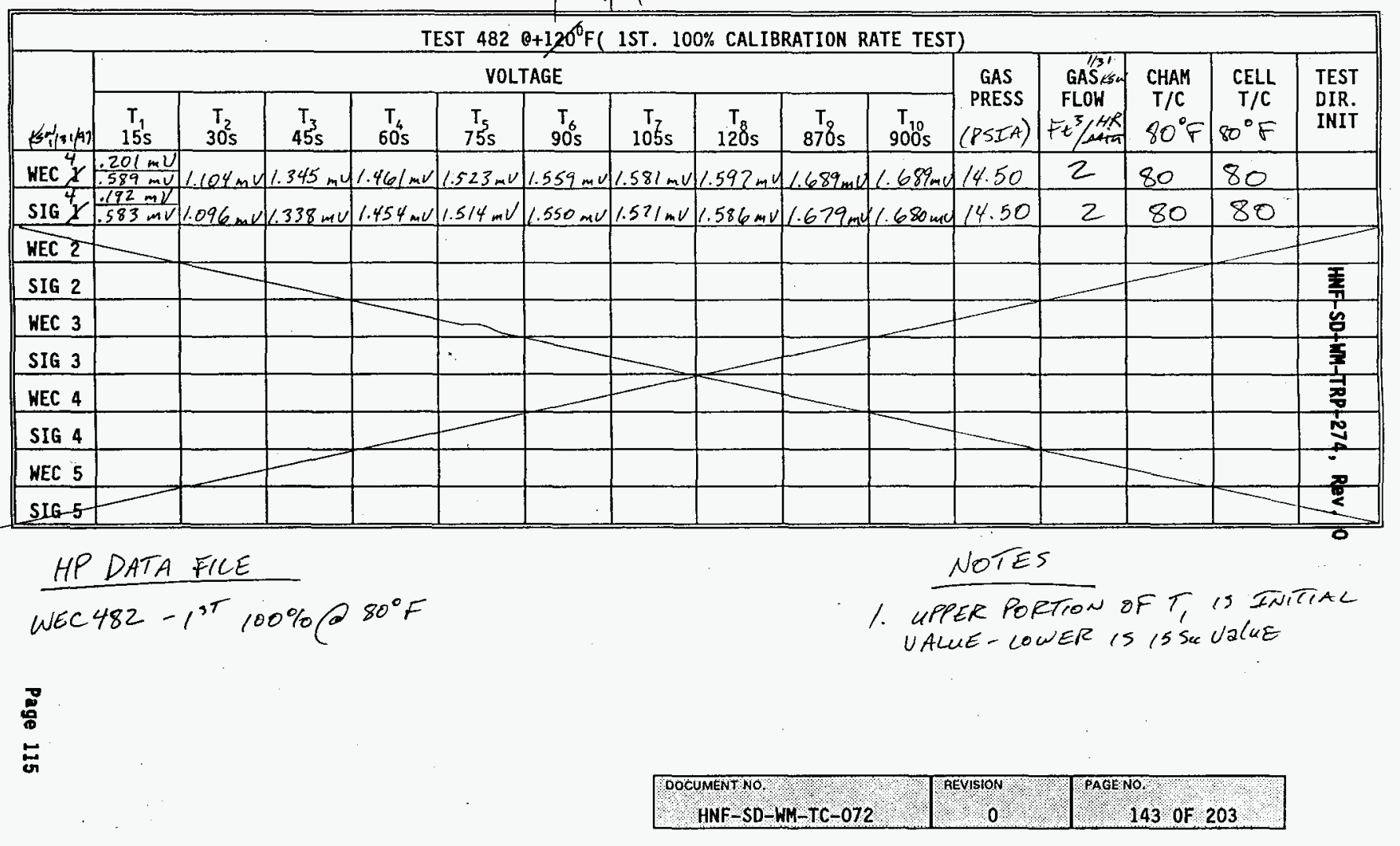

\section{HP DATA FILE}

WEC $482-1^{35} 100 \% \propto 80^{\circ} \mathrm{F}$

\section{VOLTAGE}

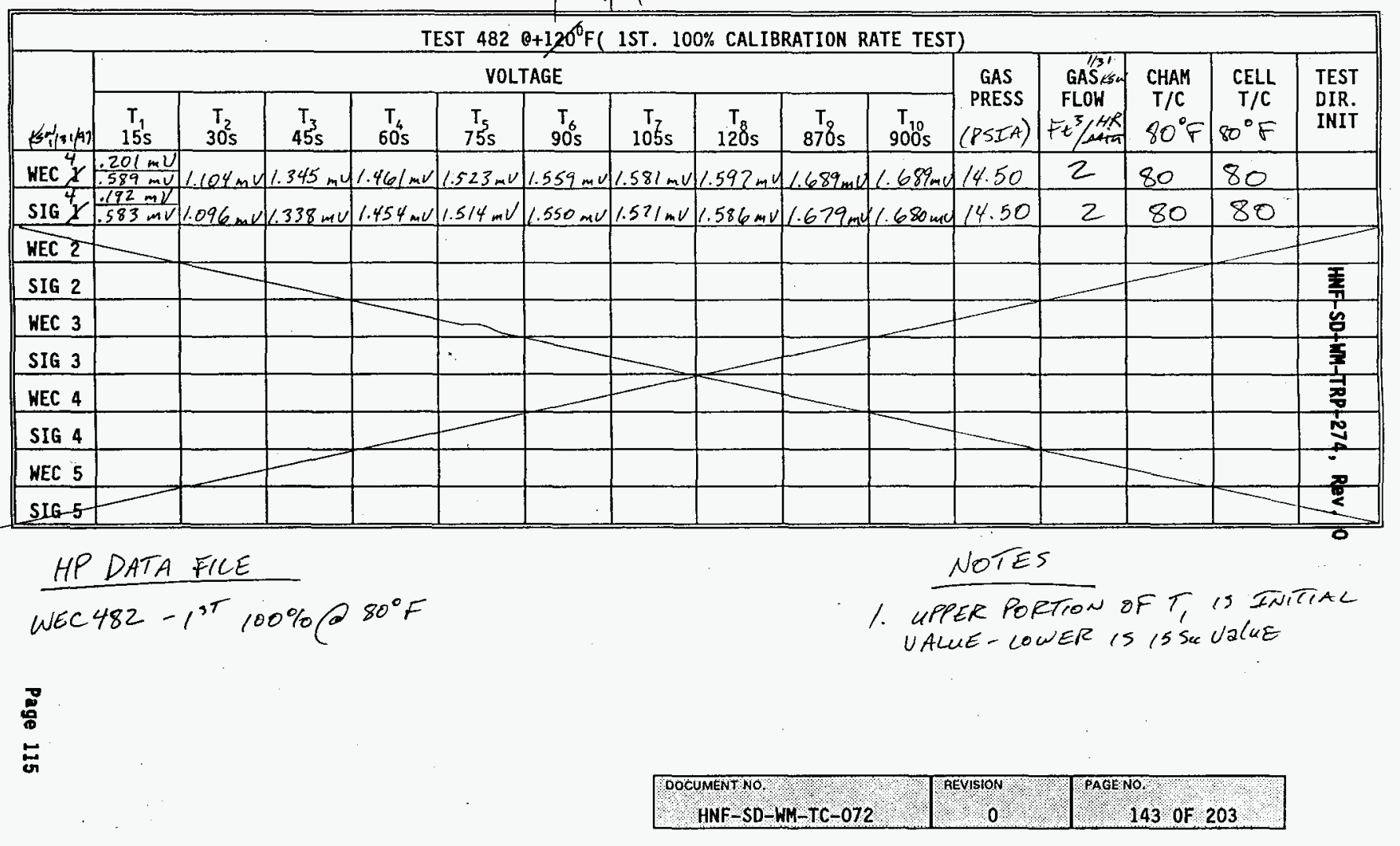

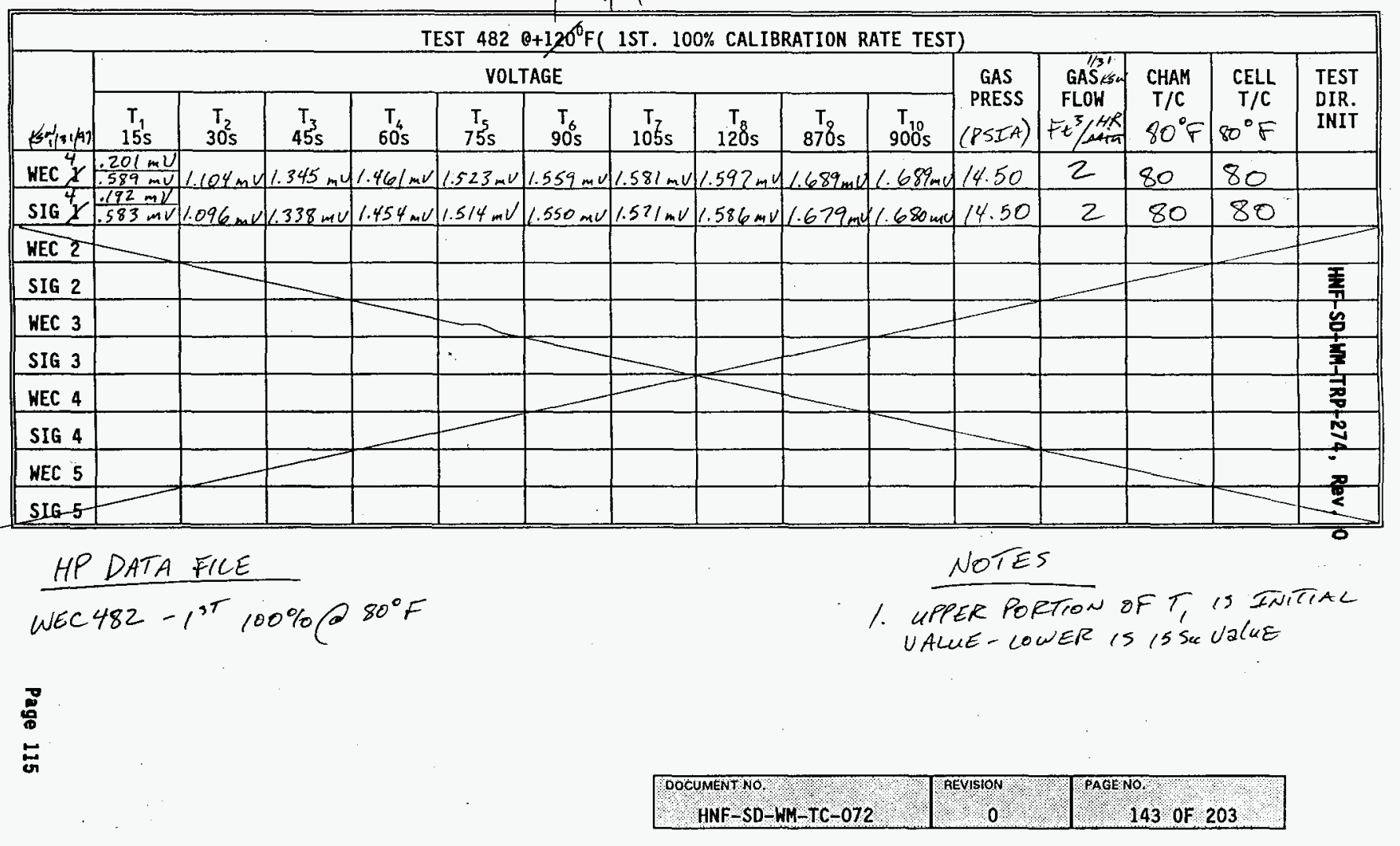

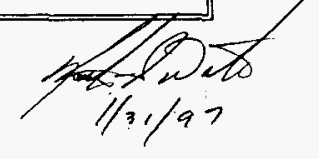


TEST PROCEDURE FOR MEASUREMENT OF PERFORMANCE VS TEMPERATURE

WHITTAKER CELL

9.127 DATA RECORD SHEET 483

TEST $4830+120^{\circ} \mathrm{F}$ ( 2ND. $100 \%$ CALIBRATION RATE TEST)

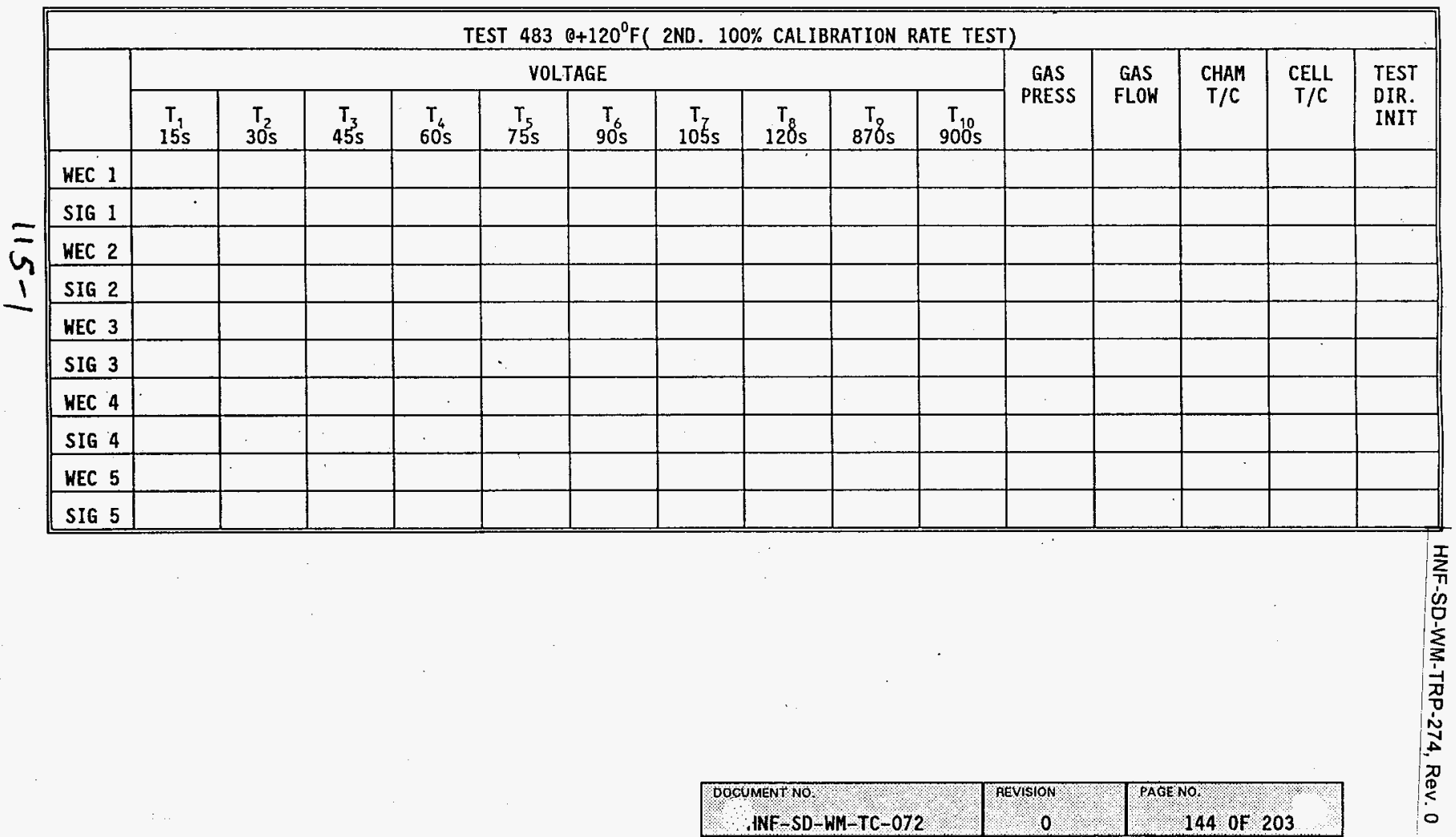


TEST PROCEDURE FOR MEASUREMENT OF PERFORMANCE VS TEMPERATURE

WHITTAKER CELL

9.128 DATA RECORD SHEET 484

TEST $4840+120^{\circ} \mathrm{F}$ (3RD. $100 \%$ CALIBRATION RATE TEST)

\begin{tabular}{||c|c|c|c|c|c|c|c|c|c|c|c|c|c|c|c||}
\hline \multicolumn{10}{|c|}{ TEST 484 0+120\% (3RD. 100\% CALIBRATION RATE TEST) } \\
\hline
\end{tabular}

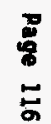




\section{TEST PROCEDURE FOR MEASUREMENT OF PERFORMANCE VS TEMPERATURE}

WHITTAKER CELL.

\subsection{DATA RECORD SHEET 511}

TEST $511-20^{\circ} \mathrm{F}(30 \%, 60 \%, 90 \%$ CALIBRATION GAS $)$

\begin{tabular}{|c|c|c|c|c|c|c|c|c|c|c|c|c|c|c|}
\hline \multicolumn{15}{|c|}{ TEST $511-20^{\circ} \mathrm{F}(30 \%, 60 \%, 90 \%$ CALIBRATION GAS) } \\
\hline & \multicolumn{3}{|c|}{ VOLTAGE $O 30 \%$ CAL. GAS } & \multicolumn{3}{|c|}{ VOLTAGE @ $60 \%$ CAL. GAS } & \multicolumn{3}{|c|}{ VOLTAGE O $90 \%$ CAL. GAS } & \multirow{2}{*}{$\begin{array}{l}\text { GAS } \\
\text { PRESS }\end{array}$} & \multirow{2}{*}{$\begin{array}{c}\text { GAS } \\
\text { FLOW }\end{array}$} & \multirow{2}{*}{$\begin{array}{l}\text { CHAMB } \\
\mathrm{T} / \mathrm{C}\end{array}$} & \multirow{2}{*}{$\begin{array}{c}\text { CELL } \\
T / C\end{array}$} & \multirow{2}{*}{$\begin{array}{l}\text { TEST } \\
\text { DIR } \\
\text { INIT }\end{array}$} \\
\hline & $\begin{array}{c}T_{1} \\
120 \mathrm{~s}\end{array}$ & ${ }_{87}{ }^{T} \partial_{\mathrm{s}}$ & $\underset{90 Z_{s}}{T_{3}}$ & ${ }_{12 d s}^{T}$ & $\begin{array}{c}\mathrm{T}^{2} \\
87 \mathrm{O}_{\mathrm{s}}\end{array}$ & $\underset{900 \mathrm{~s}}{\mathrm{~T}_{\mathrm{z}}}$ & $\begin{array}{c}T_{1} \\
120 \mathrm{~s}\end{array}$ & ${ }_{87}^{T} \partial_{\mathrm{s}}$ & $\begin{array}{c}T_{3} \\
90{ }_{s}\end{array}$ & & & & & \\
\hline WEC 1 & & & & & & & & & & & & & & \\
\hline SIG 1 & & & & & & & & & & & & & & \\
\hline WEC 2 & & & & & & & & & & & & & & \\
\hline SIG 2 & & & & & & & & & & & & & & \\
\hline WEC 3 & & & & & & & & & & & & & & \\
\hline $\operatorname{sig}_{3}$ & & & & & & & & & & & & & & \\
\hline WEC 4 & & & & & & & & & & & & & & \\
\hline $\operatorname{SIG~} 4_{4}$ & & & & & & & & & & & & & & \\
\hline WEC 5 & & & & & & & & & & & & & & \\
\hline SIG 5 & & & & & & & & & & & & & & \\
\hline
\end{tabular}


TEST PROCEDURE FOR MEASUREMENT OF PERFORMANCE VS TEMPERATURE WHITTAKER CELL

9.130 DATA RECORD SHEET 512

\begin{tabular}{|c|c|c|c|c|c|c|c|c|c|c|c|c|c|c|c|}
\hline & \multicolumn{10}{|c|}{ VOLTAGE } & \multirow{2}{*}{$\begin{array}{l}\text { GAS } \\
\text { PRESS }\end{array}$} & \multirow{2}{*}{$\begin{array}{l}\text { GAS } \\
\text { FLOW }\end{array}$} & \multirow{2}{*}{$\begin{array}{l}\text { CHAM } \\
\mathrm{T} / \mathrm{C}\end{array}$} & \multirow{2}{*}{$\begin{array}{l}\text { CELL } \\
T / C\end{array}$} & \multirow{2}{*}{$\begin{array}{l}\text { TEST } \\
\text { DIR. } \\
\text { INIT }\end{array}$} \\
\hline & $\begin{array}{r}T_{1}^{1} \\
15^{1} \mathrm{~s} \\
\end{array}$ & $\begin{array}{r}\mathrm{T}_{2} \\
30 \mathrm{~s} \\
\end{array}$ & $\begin{array}{r}T_{3}{ }^{3} s \\
45^{2} s\end{array}$ & $\begin{array}{r}T_{4} \\
60 \mathrm{~s} \\
\end{array}$ & $\begin{array}{r}T_{5} \\
75 s \\
\end{array}$ & $\begin{array}{l}T_{6} \\
90 \mathrm{~s}\end{array}$ & $\begin{array}{c}\mathrm{T}_{\mathrm{T}} \\
{ }_{105 \mathrm{~s}} \\
\end{array}$ & $\begin{array}{r}T_{8} \\
120 \mathrm{~s} \\
\end{array}$ & $\begin{array}{r}\mathrm{T} / \delta_{\mathrm{s}} \\
87 \mathrm{~s}^{2}\end{array}$ & $\begin{array}{r}\mathrm{T}_{10} \\
900 \mathrm{~s} \\
\end{array}$ & & & & & \\
\hline HEC 1 & & & & & & & & & & & & & & & \\
\hline SIG 1 & & & & & & & & & & & & & & & 포 \\
\hline HEC 2 & & & & & & & & & & & & & & & $i$ \\
\hline SIG 2 & & & & & & & & & & & & & & & $\frac{1}{1}$ \\
\hline WEC 3 & & & & & & & & & & & & & & & $\frac{1}{2}$ \\
\hline SIG 3 & & & & & & & & & & & & & & & $i$ \\
\hline WEC 4 & & & & & & & & & & & & & & & 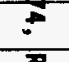 \\
\hline SIG 4 & & & & & & & & & & & & & & & 蛋 \\
\hline WEC 5 & & & & & & & & & & & & & & & 으 \\
\hline SIG 5 & & & & & & & & & & & & & & & \\
\hline
\end{tabular}

$\stackrel{8}{8}$
$\Xi$ 


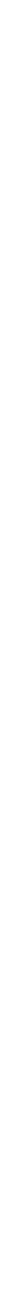


9.132 DATA RECORD SHEET 514

\begin{tabular}{|l|c|c|c|c|c|c|c|c|c|c|c|c|c|c|c|}
\hline \multicolumn{10}{||c|}{ TEST 514 Q-20 ${ }^{\circ}$ F (3RD. 100\% CALIBRATION RATE TEST) } \\
\hline
\end{tabular}

$\frac{8}{8}$

\begin{tabular}{|c|c|c|}
\hline DOCOMENTENO & REVISION & PAGENO. \\
\hline HNF - SD-WM-TC-072 & 0 & 149 OF 203 \\
\hline
\end{tabular}


TEST PROCEDURE FOR MEASUREMENT OF PERFORMANCE VS TEMPERATURE

WHITTAKER CELL.

9.133 DATA RECORD SHEET 521

$-$

TEST $5210^{\circ} \mathrm{F}(30 \%, 60 \%, 90 \%$ CALIBRATION GAS $)$

\begin{tabular}{|c|c|c|c|c|c|c|c|c|c|c|c|c|c|c|}
\hline & \multicolumn{3}{|c|}{ VOLTAGE $30 \%$ CAL. GAS } & \multicolumn{3}{|c|}{ VOLTAGE @ $60 \%$ CAL. GAS } & \multicolumn{3}{|c|}{ VOLTAGE @ $90 \%$ CAL. GAS } & \multirow{2}{*}{$\begin{array}{c}\text { GAS } \\
\text { PRESS }\end{array}$} & \multirow{2}{*}{$\begin{array}{l}\text { GAS } \\
\text { FLOW }\end{array}$} & \multirow{2}{*}{$\begin{array}{c}\text { CHAMB } \\
\mathrm{T} / \mathrm{C}\end{array}$} & \multirow{2}{*}{$\begin{array}{l}\text { CELL } \\
T / C\end{array}$} & \multirow{2}{*}{$\begin{array}{c}\text { TEST } \\
\text { DIR } \\
\text { INIT }\end{array}$} \\
\hline & ${ }_{120 \mathrm{~s}}^{\mathrm{T}_{1}}$ & $\begin{array}{c}T_{2} \\
870 \mathrm{~s} \\
\end{array}$ & $\begin{array}{c}\mathrm{T}_{3} \\
900 \mathrm{~s}\end{array}$ & $\begin{array}{c}\mathrm{T}_{\mathrm{j}} \\
120 \mathrm{~s} \\
\end{array}$ & $\begin{array}{c}T_{2} \\
870 \mathrm{~s} \\
\end{array}$ & $\begin{array}{c}\mathrm{T}_{3} \\
900 \mathrm{~s}\end{array}$ & $\begin{array}{c}\mathrm{T}_{\mathrm{s}} \\
120 \mathrm{~s}\end{array}$ & $\begin{array}{c}\mathrm{T} \\
870 \mathrm{~s} \\
\end{array}$ & $\begin{array}{c}T_{3} \\
900 \mathrm{~s}\end{array}$ & & & & & \\
\hline \multicolumn{15}{|l|}{ WEC 1} \\
\hline SIG 1 & & & & & & & & & & & & & & \\
\hline WEC 2 & & . & . & & & & & & & & & & & \\
\hline SIG 2 & & & & & & & & & & & & & & \\
\hline WEC 3 & & & & & & & & & & & & & & \\
\hline SIG 3 & & & & r & & & & & & & & & & \\
\hline WEC 4 & & & & & & & & & & & & & & \\
\hline SIG 4 & & & & & & & & & & & & & & \\
\hline WEC 5 & & & & & & & & & & & & & & \\
\hline SIG 5 & & & & & & & & & & & & & & \\
\hline
\end{tabular}

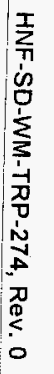


TEST PROCEDURE FOR MEASUREMENT OF PERFORMANCE VS TEMPERATURE

WHITTAKER CELL

9.134 DATA RECORD SHEET 522

\begin{tabular}{|c|c|c|c|c|c|c|c|c|c|c|c|c|c|c|c|}
\hline \multicolumn{16}{|c|}{ TEST $522000^{\circ} \mathrm{F}$ ( 1ST. $100 \%$ CALIBRATION RATE TEST) } \\
\hline & \multicolumn{10}{|c|}{ VOLTAGE } & \multirow{2}{*}{$\begin{array}{c}\text { GAS } \\
\text { PRESS }\end{array}$} & \multirow{2}{*}{$\begin{array}{l}\text { GAS } \\
\text { FLOW }\end{array}$} & \multirow{2}{*}{$\begin{array}{l}\text { CHAM } \\
\mathrm{T} / \mathrm{C}\end{array}$} & \multirow{2}{*}{$\begin{array}{c}\text { CELL } \\
\mathrm{T} / \mathrm{C}\end{array}$} & \multirow{2}{*}{$\begin{array}{l}\text { TEST } \\
\text { DIR. } \\
\text { INIT }\end{array}$} \\
\hline & $\begin{array}{r}T_{1} \\
15 s \\
\end{array}$ & $\begin{array}{r}\mathrm{T}_{2} \\
30 \mathrm{~s} \\
\end{array}$ & $\begin{array}{r}T_{3} \\
4{ }^{3} \mathrm{~s} \\
\end{array}$ & $\begin{array}{r}T_{4} \\
60 \mathrm{~s} \\
\end{array}$ & $\begin{array}{r}T_{5} \\
75^{5} \mathrm{~s} \\
\end{array}$ & $\begin{array}{r}\mathrm{T}_{6} \\
90 \mathrm{~S} \\
\end{array}$ & $\begin{array}{c}T_{T} \\
105 \mathrm{~s}\end{array}$ & $\begin{array}{c}\mathrm{T} \\
12 \delta_{\mathrm{s}} \\
\end{array}$ & $\begin{array}{c}T_{\mathrm{J}} \\
870 \mathrm{~s}\end{array}$ & $\begin{array}{r}T_{100} \\
900 \mathrm{~s}\end{array}$ & & & & & \\
\hline WEC 1 & & & & & & & & & & & & & & & \\
\hline SIG I & & & & & & & & & & & & & & & $\frac{1}{4}$ \\
\hline WEC 2 & & & & & & & & & & & & & & & i \\
\hline SIG 2 & & & & & & & & & & & & & & & $\frac{5}{1}$ \\
\hline HEC 3 & & & & & & & & & & & & & & & $\frac{\pi}{7}$ \\
\hline SIG 3 & & & & & & & & & & & & & & & \pm \\
\hline HEC 4 & & & & & & & & & & & & & & & 㞧 \\
\hline SIG 4 & & & & & & & & & & & & & & & \\
\hline WEC 5 & & & & & & & & & & & & & . & & \\
\hline SIG 5 & & & & & & & & & & & & & & & \\
\hline
\end{tabular}

莒 
TEST PROCEDURE FOR MEASUREMENT OF PERFORMANCE VS TEMPERATURE

WHITTAKER CELL

9.135 DATA RECORD SHEET 523

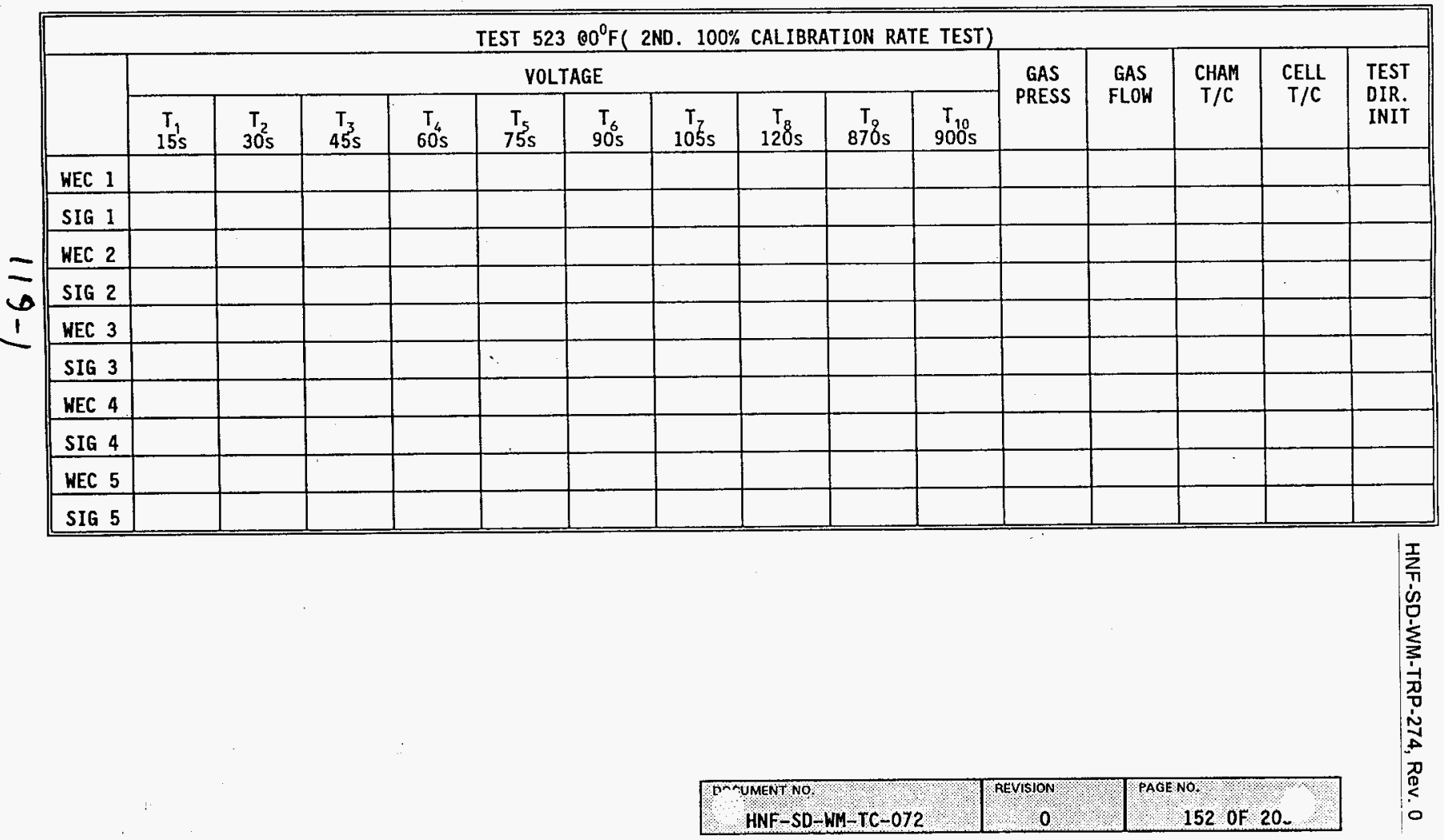


TEST PROCEDURE FOR MEASUREMENT OF PERFORMANCE VS TEMPERATURE

WHITTAKER CELL

\subsection{DATA RECORD SHEET 524}

\begin{tabular}{||c|c|c|c|c|c|c|c|c|c|c|c|c|c|c|c||}
\hline \hline \multicolumn{10}{||c|}{ TEST 524 00 ${ }^{\circ} \mathrm{F}$ 3RD. 100\% CALIGRATION RATE TEST) } \\
\hline
\end{tabular}

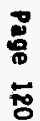


TEST PROCEDURE FOR MEASUREMENT OF PERFORMANCE VS TEMPERATURE WHITTAKER CELL

9.137 DATA RECORD SHEET 531

TEST $531+20^{\circ} \mathrm{F}(30 \%, 60 \%, 90 \%$ CALIBRATION GAS $)$

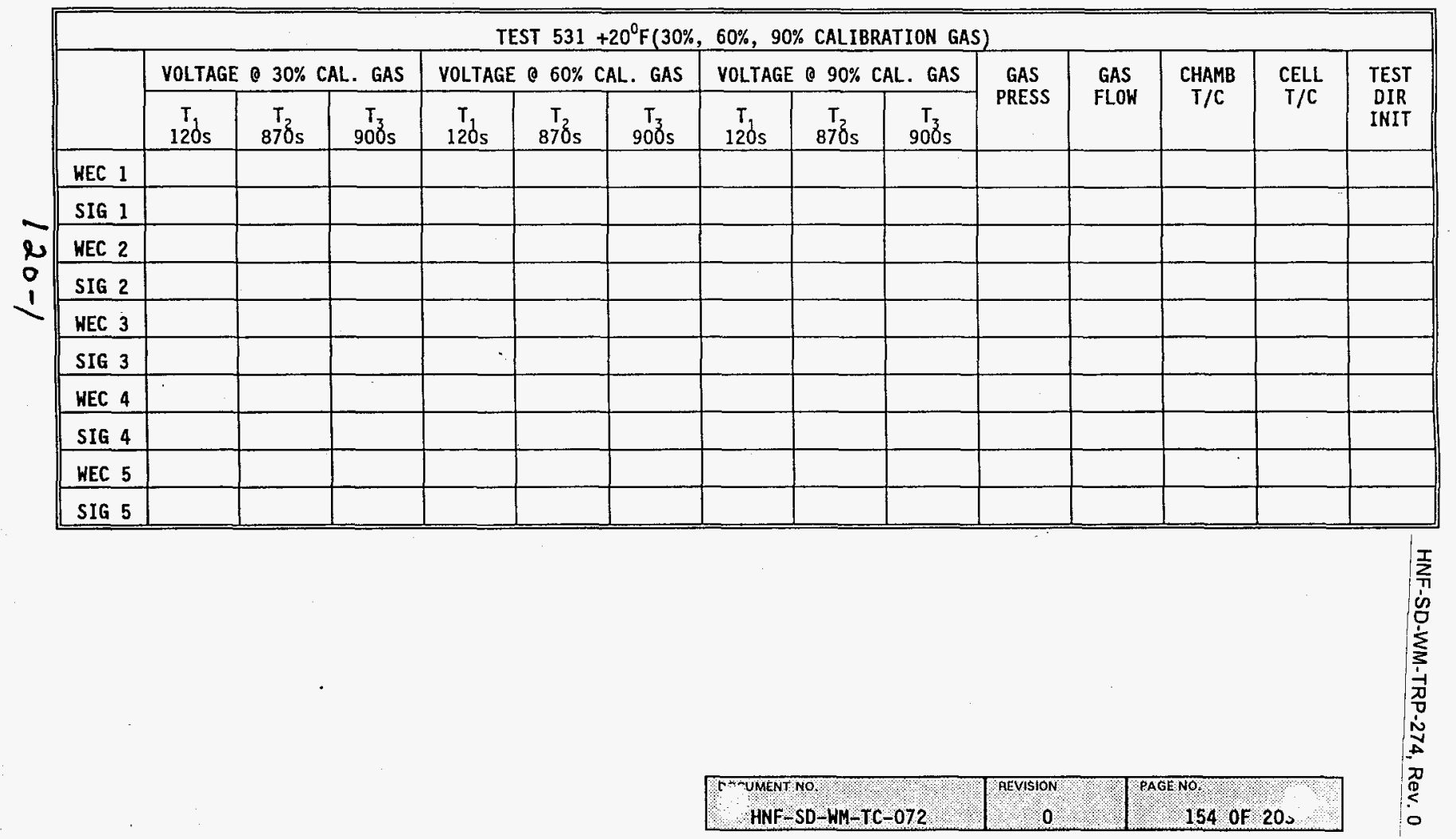


TEST PROCEDURE FOR MEASUREMENT OF PERFORMANCE VS TEMPERATURE

WHITTAKER CELL

\subsection{DATA RECORD SHEET 532}

\begin{tabular}{|c|c|c|c|c|c|c|c|c|c|c|c|c|c|c|c|}
\hline \multicolumn{16}{|c|}{ TEST $5320+20^{\circ} \mathrm{F}$ ( $1 \mathrm{ST} .100 \%$ CALIBRATION RATE TEST) } \\
\hline & \multicolumn{10}{|c|}{ VOLTAGE } & \multirow{2}{*}{$\begin{array}{c}\text { GAS } \\
\text { PRESS }\end{array}$} & \multirow{2}{*}{$\begin{array}{l}\text { GAS } \\
\text { FLOW }\end{array}$} & \multirow{2}{*}{$\begin{array}{c}\text { CHAM } \\
\mathrm{T} / \mathrm{C}\end{array}$} & \multirow{2}{*}{$\begin{array}{l}\text { CELL } \\
\text { T/C }\end{array}$} & \multirow{2}{*}{$\begin{array}{l}\text { TEST } \\
\text { IIR. } \\
\text { INIT }\end{array}$} \\
\hline & $\begin{array}{r}T_{1} \\
15 \mathrm{~s} \\
\end{array}$ & $\begin{array}{r}\mathrm{T}_{2} \\
30 \mathrm{~s} \\
\end{array}$ & $\begin{array}{r}T_{3} \\
45^{3} \mathrm{~s} \\
\end{array}$ & $\begin{array}{r}\mathrm{T}_{6} \\
60 \mathrm{~s} \\
\end{array}$ & $\begin{array}{r}T_{5} \\
75 \mathrm{~s} \\
\end{array}$ & $\begin{array}{r}\mathrm{T}_{6} \\
90 \mathrm{~s}\end{array}$ & $\begin{array}{c}\mathrm{T}_{7} \\
105 \mathrm{~s}\end{array}$ & $\begin{array}{c}\mathrm{T}_{8} \\
120 \mathrm{~s}\end{array}$ & $\begin{array}{c}\mathrm{T} \mathrm{T}_{8} \\
87 \mathrm{~s}\end{array}$ & $\begin{array}{r}\mathrm{T}_{10} \\
900 \mathrm{~s} \\
\end{array}$ & & & & & \\
\hline \multicolumn{16}{|l|}{ WEC 1} \\
\hline \multicolumn{16}{|l|}{ SIG 1} \\
\hline \multicolumn{16}{|l|}{ WEC 2} \\
\hline \multicolumn{16}{|l|}{ SIG 2} \\
\hline \multicolumn{16}{|l|}{ WEC 3} \\
\hline SIG 3 & & & & & & & & & & & & & & & 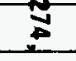 \\
\hline WEC 4 & & & & & & & & & & & & & & & T \\
\hline \multicolumn{16}{|l|}{ SIG 4} \\
\hline \multicolumn{16}{|l|}{ WEC 5} \\
\hline 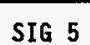 & & & & & & & & & & & & & & & \\
\hline
\end{tabular}

虽 
TEST PROCEDURE FOR MEASUREMENT OF PERFORMANCE VS TEMPERATURE WHITTAKER CELL.

9.139 DATA RECORD SHEET 533

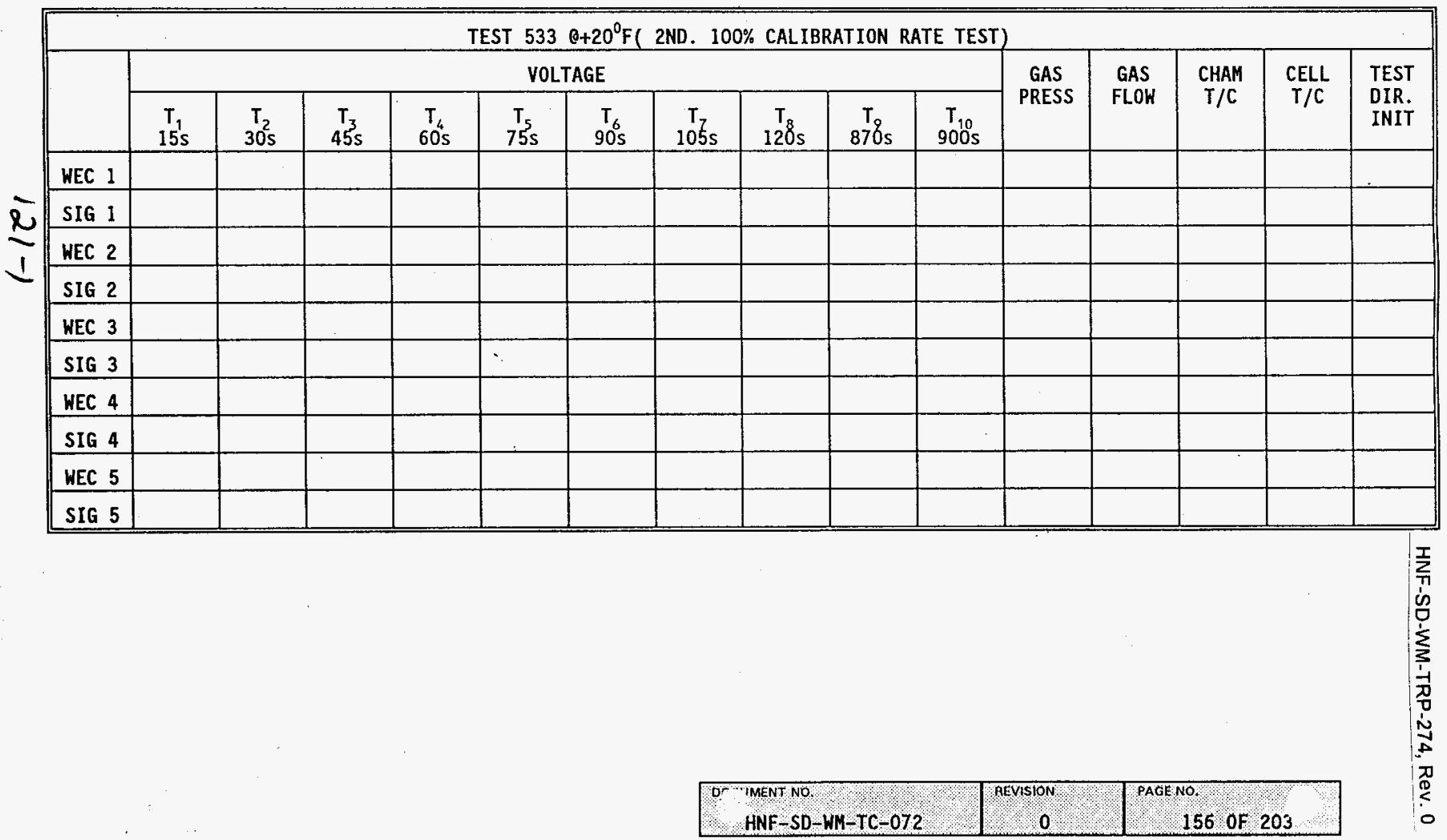


9.140 DATA RECORD SHEET 534

\begin{tabular}{|c|c|c|c|c|c|c|c|c|c|c|c|c|c|c|c|}
\hline \multicolumn{16}{|c|}{ TEST $534{ }^{\circ}+20^{\circ} \mathrm{F}$ ( 3 RD. $100 \%$ CALIBRATION RATE TEST) } \\
\hline & \multicolumn{10}{|c|}{ VOLTAGE } & \multirow{2}{*}{$\begin{array}{c}\text { GAS } \\
\text { PRESS }\end{array}$} & \multirow{2}{*}{$\begin{array}{l}\text { GAS } \\
\text { FLOW }\end{array}$} & \multirow{2}{*}{$\begin{array}{l}\text { CHAM } \\
\mathrm{T} / \mathrm{C}\end{array}$} & \multirow{2}{*}{$\begin{array}{c}\text { CELL } \\
T / C\end{array}$} & \multirow{2}{*}{$\begin{array}{l}\text { TEST } \\
\text { DIR. } \\
\text { INIT }\end{array}$} \\
\hline & $\begin{array}{r}T \\
15 \mathrm{~s} \\
\end{array}$ & $\begin{array}{r}T_{2} \\
30 \mathrm{~s} \\
\end{array}$ & $\begin{array}{r}T_{3} \\
45 s \\
\end{array}$ & $\begin{array}{r}T_{4} \\
60 \mathrm{~s} \\
\end{array}$ & $\begin{array}{r}T \\
75 s \\
75 \\
\end{array}$ & $\begin{array}{r}T_{6} \\
90 \mathrm{~s} \\
\end{array}$ & ${ }_{105 \mathrm{~s}}^{T}$ & $\begin{array}{r}T \\
120 \mathrm{~s} \\
\end{array}$ & $\begin{array}{c}T \\
870 \mathrm{~s} \\
\end{array}$ & $\begin{array}{r}T_{10} \\
900 \mathrm{~s} \\
\end{array}$ & & & & & \\
\hline \multicolumn{16}{|l|}{ HEC 1} \\
\hline \multicolumn{16}{|l|}{ SIG I } \\
\hline \multicolumn{16}{|l|}{ WEC 2} \\
\hline \multicolumn{16}{|l|}{ SIG 2} \\
\hline \multicolumn{16}{|l|}{ WEC 3} \\
\hline \multicolumn{16}{|l|}{ SIG 3} \\
\hline WEC 4 & & & & & & & & & & & & & & & $\therefore$ \\
\hline \multicolumn{16}{|l|}{ SIG 4} \\
\hline MEC 5 & & & & & & & & & & & & & & & 0 \\
\hline SIG 5 & & & & & & & & & & & & & & & \\
\hline
\end{tabular}


TEST PROCEDURE FOR MEASUREMENT OF PERFORMANCE VS TEMPERATURE WHITAKER CELL

9.142 DATA RECORD SHEET 542

G.F.Vargof

$1-28$-a ff

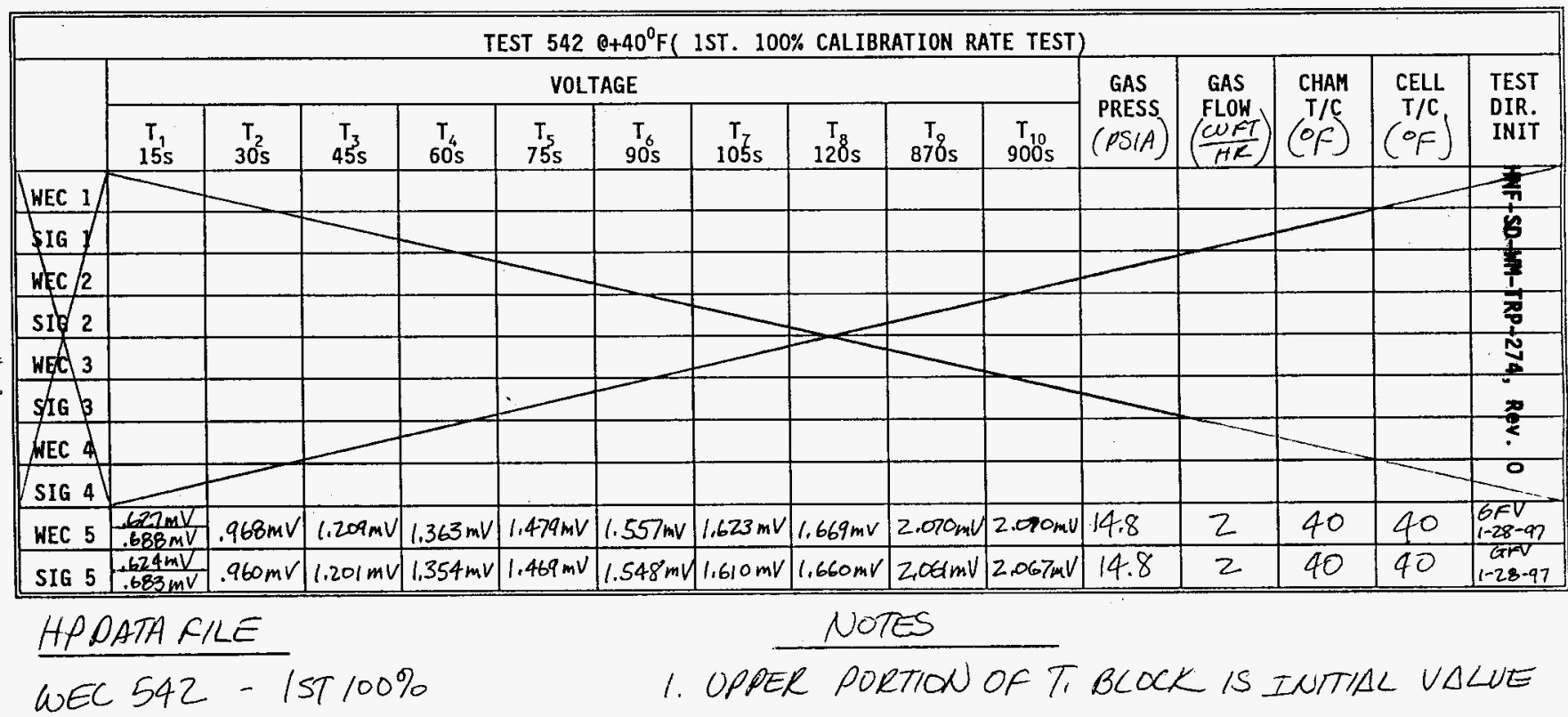

$\stackrel{\Xi}{\Xi}$

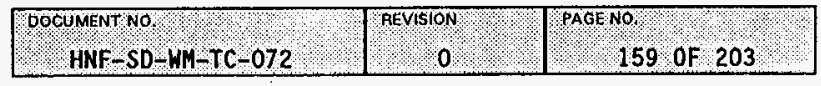


TEST PROCEDURE FOR MEASUREMENT OF PERFORMANCE VS TEMPERATURE WHITTAKER CELL

\subsection{DATA RECORD SHEET 543}

TEST $5430+40^{\circ} \mathrm{F}$ (2ND. 100\% CALIBRATION RATE TEST)

\begin{tabular}{|c|c|c|c|c|c|c|c|c|c|c|c|c|c|c|c|}
\hline \multicolumn{16}{|c|}{ TEST $5430+40^{\circ} \mathrm{F}$ ( 2ND. $100 \%$ CALIBRATION RATE TEST) } \\
\hline & \multicolumn{10}{|c|}{ VOLTAGE } & \multirow{2}{*}{$\begin{array}{c}\text { GAS } \\
\text { PRESS } \\
(O S / A)\end{array}$} & \multirow{2}{*}{$\begin{array}{c}\text { GAS } \\
\text { FLOW } \\
\left(\frac{W E I}{A P}\right)\end{array}$} & \multirow{2}{*}{$\begin{array}{l}\text { CHAM } \\
\text { T/C } \\
(O F)\end{array}$} & \multirow{2}{*}{$\begin{array}{l}\text { CELL } \\
\text { T/G } \\
\text { OFF) }\end{array}$} & \multirow{2}{*}{$\begin{array}{l}\text { TEST } \\
\text { DIR. } \\
\text { INIT }\end{array}$} \\
\hline & $\begin{array}{r}\mathrm{T}_{1} \\
15 \mathrm{~s} \\
\end{array}$ & $\begin{array}{r}\mathrm{T}_{2} \\
30 \mathrm{~s} \\
\end{array}$ & $\begin{array}{r}T_{3} \\
45 s \\
\end{array}$ & $\begin{array}{r}T_{4} \\
60 \mathrm{~s} \\
\end{array}$ & $\begin{array}{r}T_{5} \\
75 \mathrm{~s} \\
\end{array}$ & $\begin{array}{r}\mathrm{T}_{6} \\
90 \mathrm{~S}\end{array}$ & ${ }_{105 s}$ & $\begin{array}{c}T_{8} \\
120 \mathrm{~s} \\
\end{array}$ & $\begin{array}{c}T_{9} \\
870 \mathrm{~s}\end{array}$ & $\begin{array}{c}T_{10} \\
900 \mathrm{~s}\end{array}$ & & & & & \\
\hline WEC 1 & & & & & & & & & & & & & & & \\
\hline SIG & & & & & & & & & & & & & & & \\
\hline $\mathrm{MEC} / 2$ & & & & & & & & & & & & & & & \\
\hline $\operatorname{sig} 2$ & & & & & & & & & & & & & & & \\
\hline WEA 3 & & & & & & & & & & & & & & & \\
\hline $5 \mathrm{ig} 3$ & & & & & & & & & & & & & & & \\
\hline WEC 4 & & & & & & & & & & & & & & & \\
\hline SIG 4 & & & & & & & & & & & & & & & \\
\hline WEC 5 & $\begin{array}{l}.657 \mathrm{mV} \\
.730 \mathrm{mV}\end{array}$ & $.994 \mathrm{mV}$ & $1.221 \mathrm{mV}$ & $1.381 \mathrm{mV}$ & $1.489 \mathrm{mV}$ & $1.568 \mathrm{mV}$ & $1634 \mathrm{mV}$ & $1.673 \mathrm{hV}$ & $2,084 \mathrm{mV}$ & $2.077 \mathrm{mV}$ & 14.82 & 2 & 40 & 40 & $\begin{array}{l}6 F V \\
1-25.97\end{array}$ \\
\hline
\end{tabular}

AP DATA FILE

WEC $543-200100 \%$
NOTES

1. UPPER PORTION OF TI BLOCK IS INITIAL VALUE. 
TEST PROCEDURE FOR MEASUREMENT OF PERFORMANCE VS TEMPERATURE

WHITTAKER CELL

9.144 DATA RECORD SHEET 544

TEST $5440+40^{\circ} \mathrm{F}$ ( 3RD. 100\% CALIBRATION RATE TEST)

\begin{tabular}{|c|c|c|c|c|c|c|c|c|c|c|c|c|c|c|c|}
\hline & \multicolumn{10}{|c|}{ VOLTAGE } & \multirow{2}{*}{$\begin{array}{c}\text { GAS } \\
\text { PRESS } \\
(\not S / A)\end{array}$} & \multirow{2}{*}{ 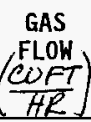 } & \multirow{2}{*}{$\left.\begin{array}{c}\text { CHAM } \\
\text { T/C } \\
O F\end{array}\right)$} & \multirow{2}{*}{$\begin{array}{c}\text { CELL } \\
\left(\begin{array}{c}\mathrm{T} / \mathrm{C} \\
{ }^{\circ} F\end{array}\right)\end{array}$} & \multirow{2}{*}{$\begin{array}{l}\text { TEST } \\
\text { DIR. } \\
\text { INIT }\end{array}$} \\
\hline & $\begin{array}{c}\mathrm{T}_{1} \\
15 \mathrm{~s}\end{array}$ & $\begin{array}{c}\mathrm{T}_{2} \\
30 \mathrm{~s} \\
\end{array}$ & $\begin{array}{r}T_{3} \\
45 s \\
\end{array}$ & $\begin{array}{c}T_{4} \\
60 \mathrm{~s} \\
\end{array}$ & $\begin{array}{c}T \\
75 s \\
\end{array}$ & $\begin{array}{c}T_{6} \\
90 \mathrm{~s}\end{array}$ & ${ }_{105}^{\mathrm{T}} 7$ & $\begin{array}{c}T_{8} \\
120 \mathrm{~s} \\
\end{array}$ & $\begin{array}{c}T \\
87 \% \mathrm{~s} \\
\end{array}$ & $\begin{array}{c}T_{10} \\
900 \mathrm{~s}\end{array}$ & & & & & \\
\hline WEC $1 /$ & & & & & & & & & & & & & & & \\
\hline IIG & & & & & & & & & & & & & & & \\
\hline wec/2 & & & & & & & & & & & & & & & \\
\hline sid 2 & & & & & & & & & & & & & & & \\
\hline $\mathrm{HEC}_{3}$ & & & & & & & & & & & & & & & $\stackrel{\vec{D}}{\oplus}$ \\
\hline $\operatorname{sig} B$ & & & & & & & & & & & & & & & $P$ \\
\hline WEC 4 & & & & & & & & & & & & & & & \\
\hline SIG 4 & & & & & & & & & & & & & & & \\
\hline WEC 5 & $\begin{array}{l}.671 \mathrm{mV} \\
.739 \mathrm{mV}\end{array}$ & $.998 \mathrm{mV}$ & $1.225 \mathrm{mV}$ & $1.384 \mathrm{mv}$ & $1.498 \mathrm{nV}$ & $1.578 \mathrm{mV}$ & $1.628 \mathrm{mV}$ & $1.688 \mathrm{mv}$ & & & 14.81 & 2 & 40 & 40 & $\begin{array}{l}6 F V \\
1.28-97\end{array}$ \\
\hline SIG 5 & $\frac{.664 \mathrm{mV}}{.729 \mathrm{mv}}$ & $.989 \mathrm{mV}$ & $1.222 \mathrm{mV}$ & $1.382 \mathrm{mV}$ & $1.492 \mathrm{mV}$ & $1.571 \mathrm{mV}$ & $1.623 \mathrm{mV}$ & $1.677 \mathrm{mV}$ & & & 14.81 & 2 & 40 & 40 & $\begin{array}{l}6 F V \\
1.28 .97\end{array}$ \\
\hline
\end{tabular}

HP DATA FILE

WEC $544-3 R D 100 \%$

FILE ACCNOZTALCY ABORTED \& 810 SELS

I. RESTARTED ONDER FILE WEC S44B.
NOTES

1. UPPER PORTION OF T, BLOCK IS INTTAL VALUE.

2 FILE ON COMPUTCE LNAS INADUERTANTLY ABORTED AND STARTED 30 SECS LATER AS WEC $544 \mathrm{~B}$ 


\section{TEST PROCEDURE FOR MEASUREMENT OF PERFORMANCE VS TEMPERATURE}

WHITTAKER CELL

\subsection{DATA RECORD SHEET 551}

\section{$+$}

$\therefore \quad$

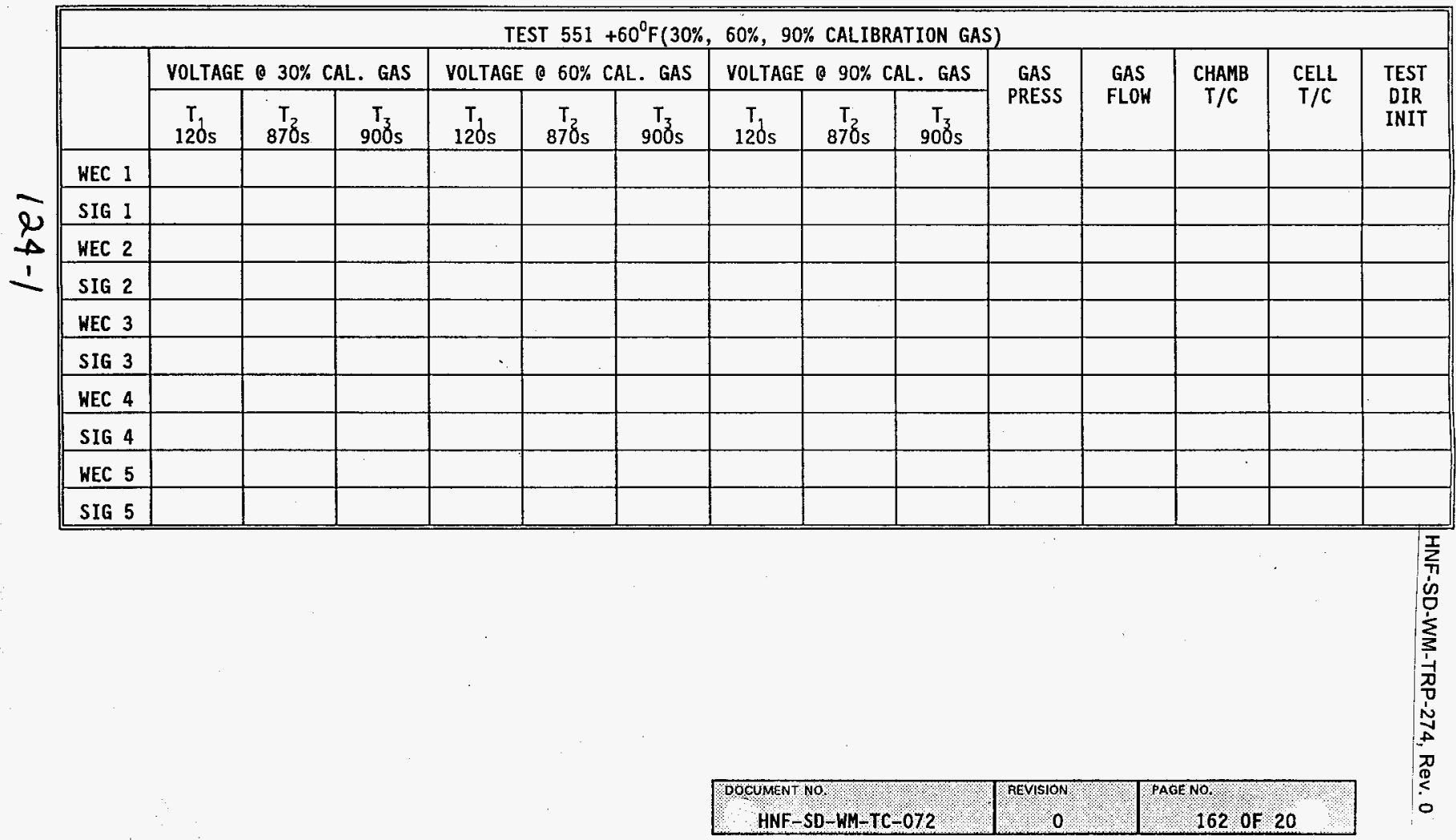


TEST PROCEDURE FOR MEASUREMENT OF PERFORMANCE VS TEMPERATURE WHITTAKER CELL

9.146 DATA RECORD SHEET 552

\begin{tabular}{|c|c|c|c|c|c|c|c|c|c|c|c|c|c|c|c|}
\hline \multicolumn{16}{|c|}{ TEST $5520+60^{\circ} \mathrm{F}$ (1ST. $100 \%$ CALIBRATION RATE TEST) } \\
\hline & \multicolumn{10}{|c|}{ VOLTAGE } & \multirow{2}{*}{$\begin{array}{l}\text { GAS } \\
\text { PRESS }\end{array}$} & \multirow{2}{*}{$\begin{array}{l}\text { GAS } \\
\text { FLOW }\end{array}$} & \multirow{2}{*}{$\begin{array}{l}\text { CHAM } \\
T / C\end{array}$} & \multirow{2}{*}{$\begin{array}{l}\text { CELL } \\
T / C\end{array}$} & \multirow{2}{*}{$\begin{array}{l}\text { TEST } \\
\text { IIR. } \\
\text { INIT }\end{array}$} \\
\hline & $\begin{array}{c}T_{1} \\
15 s\end{array}$ & $\begin{array}{c}T_{2} \\
30 s\end{array}$ & $\begin{array}{c}T_{3} \\
455\end{array}$ & $\begin{array}{c}\mathrm{T}_{4} \\
60 \mathrm{~s}\end{array}$ & $\begin{array}{c}T_{5} \\
755\end{array}$ & $\begin{array}{c}T_{\sigma} \\
90 \mathrm{~s}\end{array}$ & 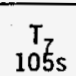 & ${ }_{120 \mathrm{~s}}^{T_{\mathrm{g}}}$ & $\begin{array}{c}T_{8} q_{s}\end{array}$ & $\begin{array}{c}T_{10} \\
900 \mathrm{~s}\end{array}$ & & & & & \\
\hline \multicolumn{16}{|l|}{ WEC 1} \\
\hline SIG 1 & & & & & & & & & & & & & & & 王 \\
\hline \multicolumn{16}{|l|}{ HEC 2} \\
\hline SIG 2 & & & & & & & & & & & & & & & $\frac{1}{3}$ \\
\hline \multicolumn{16}{|l|}{ HEC 3} \\
\hline \multicolumn{16}{|l|}{ SIG 3} \\
\hline \multicolumn{16}{|l|}{ WEC 4} \\
\hline SIG 4 & & & & & & & & & & & & & & & 帝 \\
\hline HEC 5 & & & & & & & & & & & & & & & 0 \\
\hline SIG 5 & & & & & & & & & & & & & & & \\
\hline
\end{tabular}

芯
品 
TEST PROCEDURE FOR MEASUREMENT OF PERFORMANCE VS TEMPERATURE

WHITTAKER CELL

9.147 DATA RECORD SHEET 553

TEST $5530+60^{\circ} \mathrm{F}$ ( 2ND. $100 \%$ CALIBRATION RATE TEST)

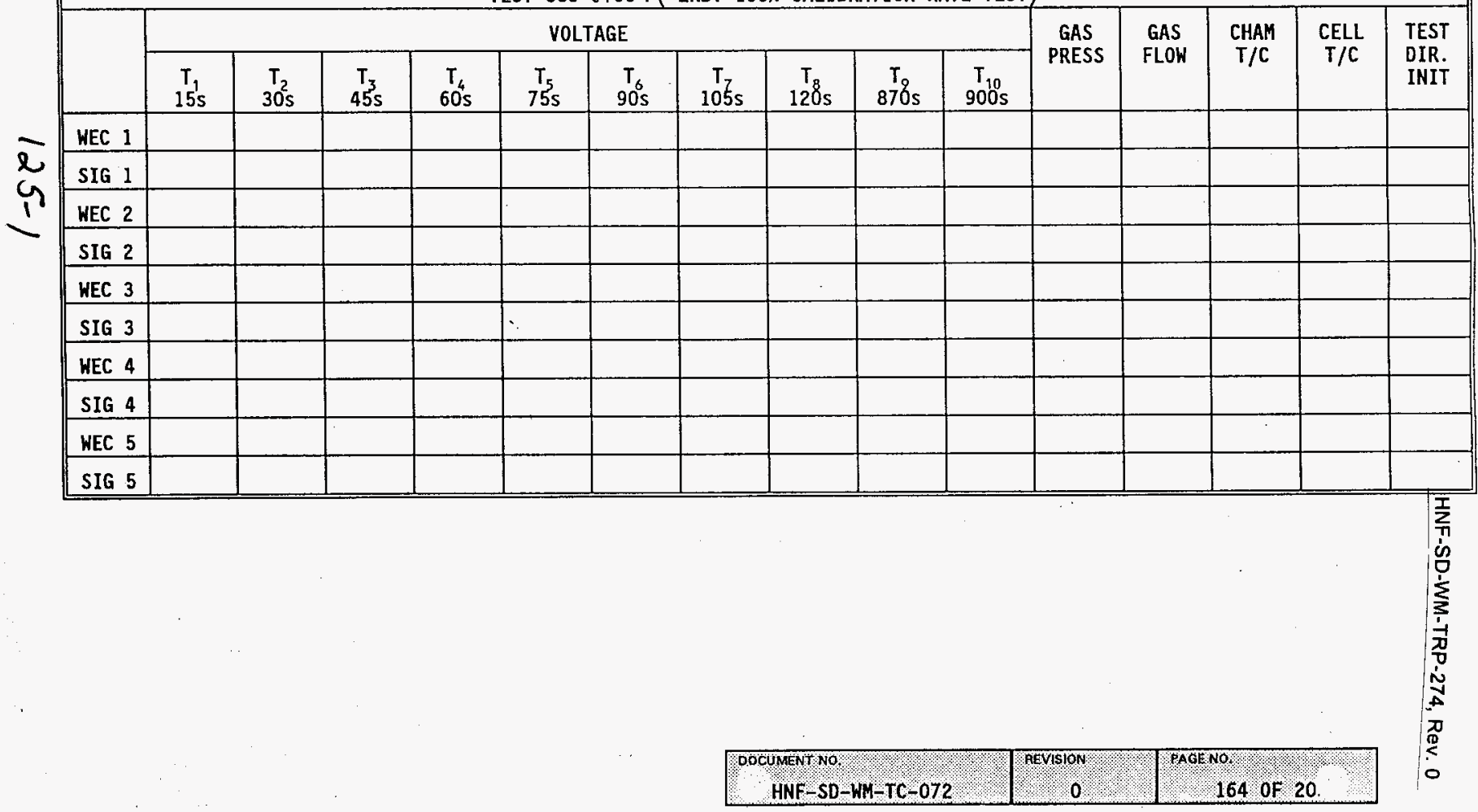


TEST PROCEDURE FOR MEASUREMENT OF PERFORMANCE VS TEMPERATURE

WHITTAKER CELL

9.148 DATA RECORD SHEET 554

\begin{tabular}{|c|c|c|c|c|c|c|c|c|c|c|c|c|c|c|c|}
\hline \multicolumn{16}{|c|}{ TEST $5540+60^{\circ} \mathrm{F}$ (3RD. 100\% CALIBRATION RATE TEST) } \\
\hline & \multicolumn{10}{|c|}{ VOLTAGE } & \multirow{2}{*}{$\begin{array}{l}\text { GAS } \\
\text { PRESS }\end{array}$} & \multirow{2}{*}{$\begin{array}{l}\text { GAS } \\
\text { FLOW }\end{array}$} & \multirow{2}{*}{$\begin{array}{l}\text { CHAM } \\
\mathrm{T} / \mathrm{C}\end{array}$} & \multirow{2}{*}{$\begin{array}{c}\text { CELL } \\
\mathrm{T} / \mathrm{C}\end{array}$} & \multirow{2}{*}{$\begin{array}{l}\text { TEST } \\
\text { DIR. } \\
\text { INIT }\end{array}$} \\
\hline & $\begin{array}{r}T_{1} \\
15 \mathrm{~s} \\
\end{array}$ & $\begin{array}{r}T_{2}^{2} \\
30^{2} s\end{array}$ & $\begin{array}{r}T_{3}^{3} \\
45^{5} \\
\end{array}$ & $\begin{array}{c}T_{4} \\
60 \mathrm{~s}\end{array}$ & $\begin{array}{c}T_{5} \\
75_{5}\end{array}$ & $\begin{array}{c}T_{6} \\
90 \mathrm{~s}\end{array}$ & ${ }_{105 \mathrm{~s}}^{\mathrm{T}}$ & $\begin{array}{c}\mathrm{T}_{\mathrm{s}} \\
12 \delta \mathrm{s}\end{array}$ & $\begin{array}{c}\mathrm{T} / \mathrm{s}_{\mathrm{s}} \\
870 \mathrm{~s}\end{array}$ & $\begin{array}{c}T_{10} \\
900 \mathrm{~s}\end{array}$ & & & & & \\
\hline \multicolumn{16}{|l|}{ WEC I } \\
\hline \multicolumn{16}{|l|}{ SIG 1} \\
\hline \multicolumn{16}{|l|}{ WEC 2} \\
\hline \multicolumn{16}{|l|}{ SIG 2} \\
\hline \multicolumn{16}{|l|}{ WEC 3} \\
\hline \multicolumn{16}{|l|}{ SIG 3} \\
\hline MEC 4 & & & & & & & & & & & & & & & $\$$ \\
\hline SIG 4 & & & & & & & & & & & & & & & गु \\
\hline WEC 5 & & & & & & & & & & & & & & & io \\
\hline SIG 5 & & & & & & & & & & & & & & & \\
\hline
\end{tabular}

8
0 


\section{TEST PROCEDURE FOR MEASUREMENT OF PERFORMANCE VS TEMPERATURE}

WHITTAKER CELL

\subsection{DATA RECORD SHEET 561}

TEST $561+80^{\circ} \mathrm{F}(30 \%, 60 \%, 90 \%$ CALIBRATION GAS $)$

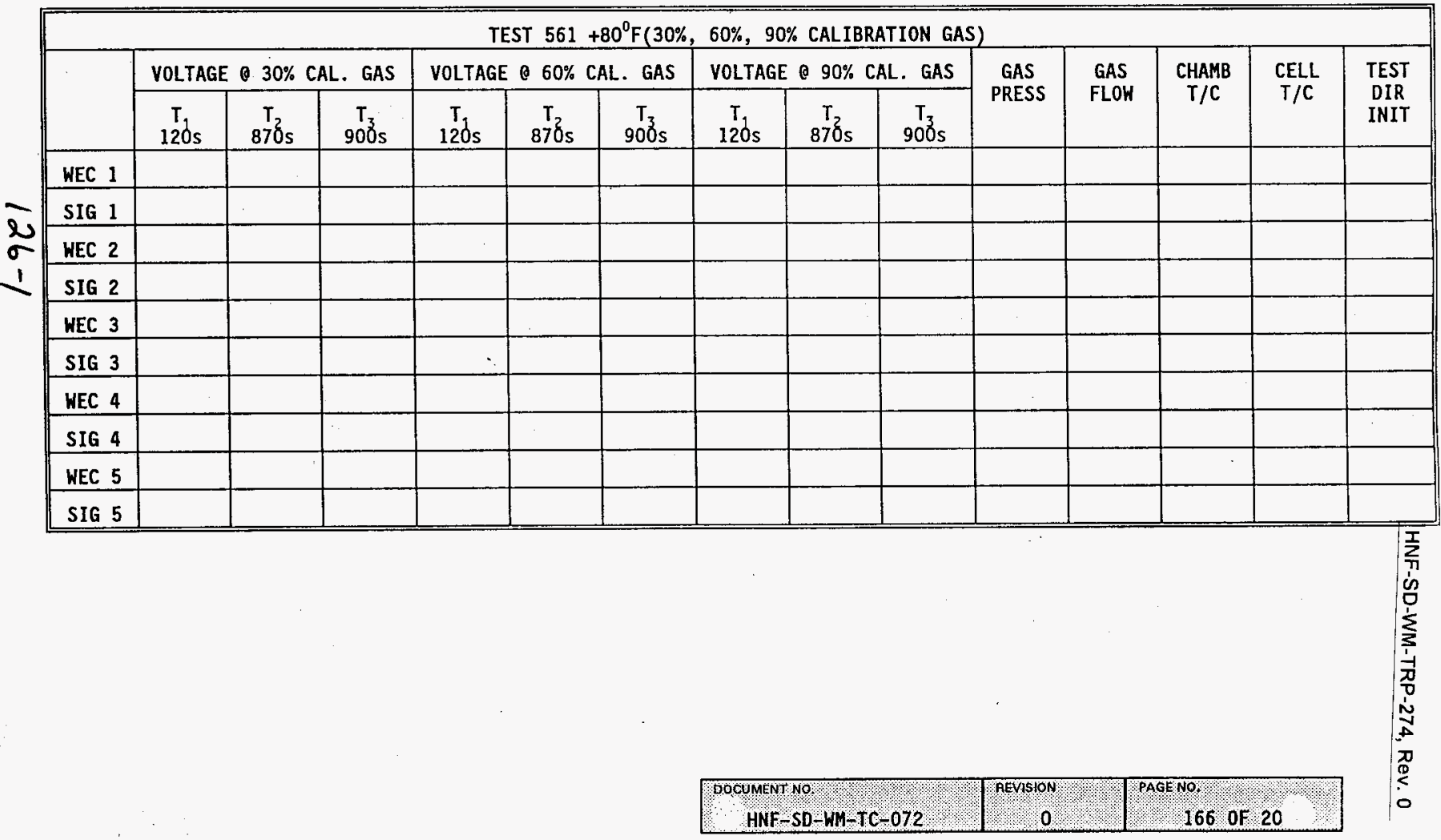


TEST PROCEDURE FOR MEASUREMENT OF PERFORMANCE VS TEMPERATURE WHITAKER CELL

9.150 DATA RECORD SHEET 562

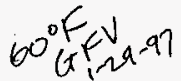

$\underset{1-29-970}{G+\operatorname{Vargog}}$

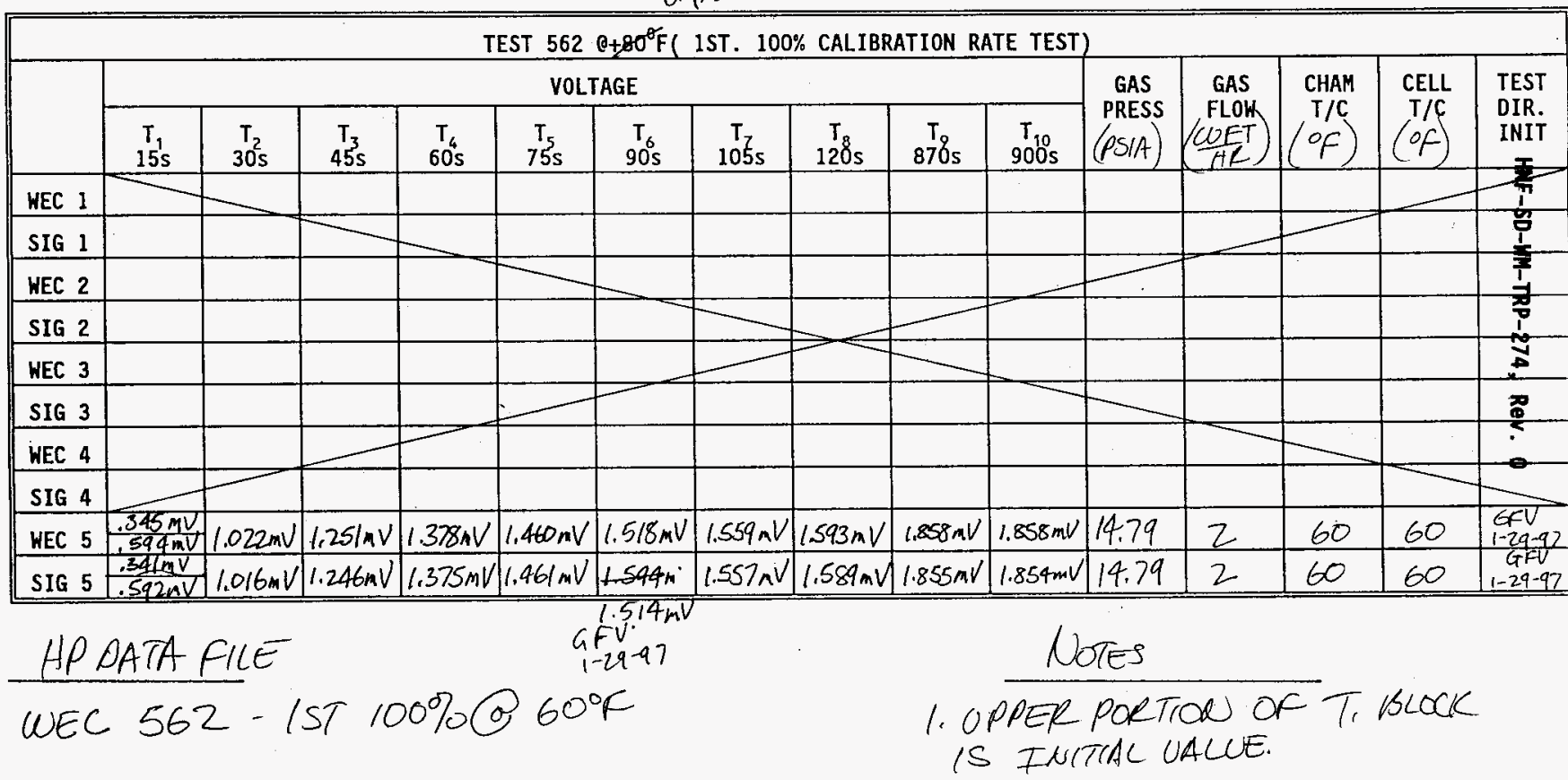

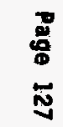

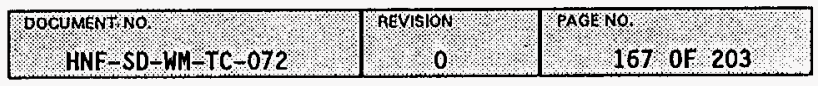


TEST PROCEDURE FOR MEASUREMENT OF PERFORMANCE VS TEMPERATURE

WHITTAKER CELL.

9.151 DATA RECORD SHEET 563

TEST $5630+80^{\circ} \mathrm{F}$ ( 2ND. 100\% CALIBRATION RATE TEST)

\begin{tabular}{|c|c|c|c|c|c|c|c|c|c|c|c|c|c|c|c|}
\hline & \multicolumn{10}{|c|}{ VOLTAGE } & \multirow{2}{*}{$\begin{array}{c}\text { GAS } \\
\text { PRESS }\end{array}$} & \multirow{2}{*}{$\begin{array}{l}\text { GAS } \\
\text { FLOW }\end{array}$} & \multirow{2}{*}{$\begin{array}{l}\text { CHAM } \\
T / C\end{array}$} & \multirow{2}{*}{$\begin{array}{c}\text { CELL } \\
T / C\end{array}$} & \multirow{2}{*}{$\begin{array}{l}\text { TEST } \\
\text { DIR. } \\
\text { INIT }\end{array}$} \\
\hline & $\begin{array}{c}T_{1} \\
15 \mathrm{~s} \\
\end{array}$ & $\begin{array}{c}T_{2} \\
30 \mathrm{~s} \\
\end{array}$ & $\begin{array}{r}T_{3} \\
45 \mathrm{~s} \\
\end{array}$ & $\begin{array}{r}T_{4} \\
60 \mathrm{~s} \\
\end{array}$ & $\begin{array}{r}\mathrm{T}_{5} \\
75 \mathrm{~s} \\
\end{array}$ & $\begin{array}{r}\mathrm{T}_{6} \\
90 \mathrm{~s} \\
\end{array}$ & ${ }_{105 \mathrm{~s}}^{\mathrm{T}_{7}}$ & $\begin{array}{c}\mathrm{T}_{8} \\
120 \mathrm{~s} \\
\end{array}$ & $\begin{array}{c}T_{8} \\
870 \mathrm{~s}\end{array}$ & $\begin{array}{c}\mathrm{T}_{10} \\
900 \mathrm{~s} \\
\end{array}$ & & & & & \\
\hline \multicolumn{16}{|l|}{ WEC 1} \\
\hline \multicolumn{16}{|l|}{ SIG 1} \\
\hline \multicolumn{16}{|l|}{ WEC 2} \\
\hline \multicolumn{16}{|l|}{ SIG 2} \\
\hline \multicolumn{16}{|l|}{ WEC 3} \\
\hline \multicolumn{16}{|l|}{ SIG 3} \\
\hline \multicolumn{16}{|l|}{ WEC 4} \\
\hline \multicolumn{16}{|l|}{ SIG 4} \\
\hline \multicolumn{16}{|l|}{ WEC 5} \\
\hline SIG 5 & & & & & & & & & & & & & & & \\
\hline
\end{tabular}

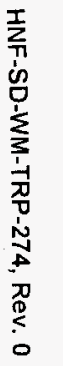


TEST PROCEDURE FOR MEASUREMENT OF PERFORMANCE VS TEMPERATURE WHITTAKER CELL

\subsection{DATA RECORD SHEET 564}

\begin{tabular}{|c|c|c|c|c|c|c|c|c|c|c|c|c|c|c|c|}
\hline \multicolumn{16}{|c|}{ TEST $564 @+80^{\circ} \mathrm{F}$ ( 3 RD. $100 \%$ CALIBRATION RATE TEST) } \\
\hline & \multicolumn{10}{|c|}{ VOLTAGE } & \multirow{2}{*}{$\begin{array}{c}\text { GAS } \\
\text { PRESS }\end{array}$} & \multirow{2}{*}{$\begin{array}{l}\text { GAS } \\
\text { FLOW }\end{array}$} & \multirow{2}{*}{$\begin{array}{l}\text { CHAM } \\
\text { T/C }\end{array}$} & \multirow{2}{*}{$\begin{array}{l}\text { CELL } \\
T / C\end{array}$} & \multirow{2}{*}{$\begin{array}{l}\text { TEST } \\
\text { DIR. } \\
\text { INIT }\end{array}$} \\
\hline & $\begin{array}{r}T_{1}^{1} \\
15 s\end{array}$ & $\begin{array}{l}T_{2} \\
30 \mathrm{~s}\end{array}$ & $\begin{array}{r}T_{3} \\
45 s \\
\end{array}$ & $\begin{array}{l}T_{4} \\
60 \mathrm{~s} \\
\end{array}$ & $\begin{array}{r}T_{5} \\
755 s \\
\end{array}$ & $\begin{array}{c}T_{6}{ }_{6} \\
90 \mathrm{~s}\end{array}$ & $\begin{array}{c}{ }^{\mathrm{T}} \bar{T}_{\mathrm{s}} \\
05 \mathrm{~s}\end{array}$ & ${ }_{120 \mathrm{~s}}^{\mathrm{T}}$ & $\begin{array}{c}\mathrm{T}_{87} \\
87 \mathrm{~s}\end{array}$ & $\begin{array}{l}T_{10} \\
900 \mathrm{~s}\end{array}$ & & & & & \\
\hline \multicolumn{16}{|l|}{ WEC 1} \\
\hline SIG I & & & & & & & & & & & & & & & 冡 \\
\hline MEC 2 & & & & & & & & & & & & & & & s \\
\hline SIG 2 & & & & & & & & & & & & & & & $\frac{\bar{x}}{1}$ \\
\hline WEC 3 & & & & & & & & & & & & & & & 궁 \\
\hline SIG 3 & & & & & & & & & & & & & & & $\frac{1}{N}$ \\
\hline \multicolumn{16}{|l|}{ WEC 4} \\
\hline \multicolumn{16}{|l|}{$51 \mathrm{SI}$} \\
\hline HEC 5 & & & & & & & & & & & & & & & 0 \\
\hline SIG 5 & & & & & & & & & & & & & & & \\
\hline
\end{tabular}

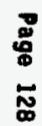


TEST PROCEDURE FOR MEASUREMENT OF PERFORMANCE VS TEMPERATURE

WHITTAKER CELL

9.153 DATA RECORD SHEET 571

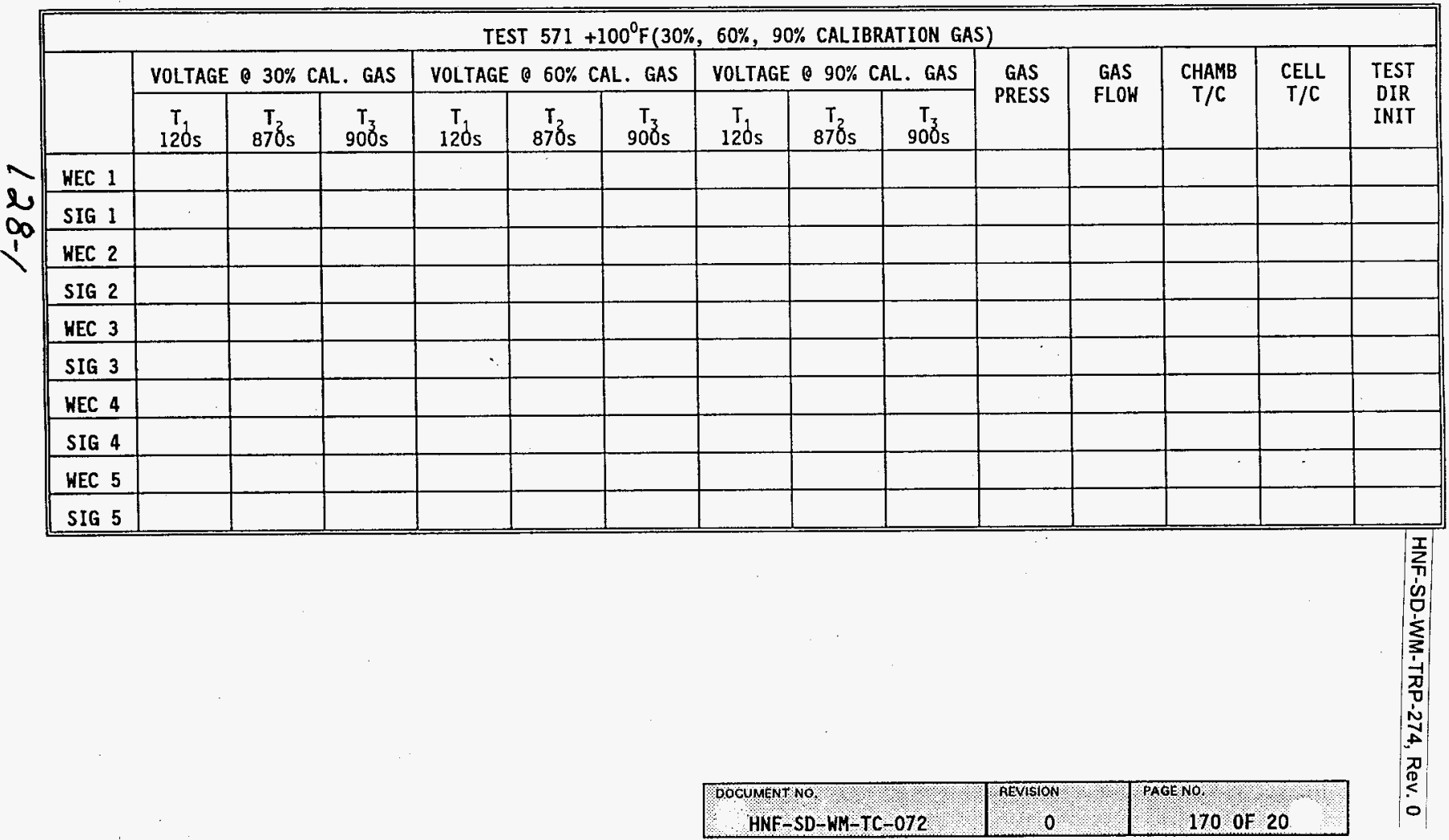


TEST PROCEDURE FOR MEASUREMENT OF PERFORMANCE VS TEMPERATURE WHITAKER CELL

9.154 DATA. RECORD SHEET $572, \cdots 70^{\circ}$

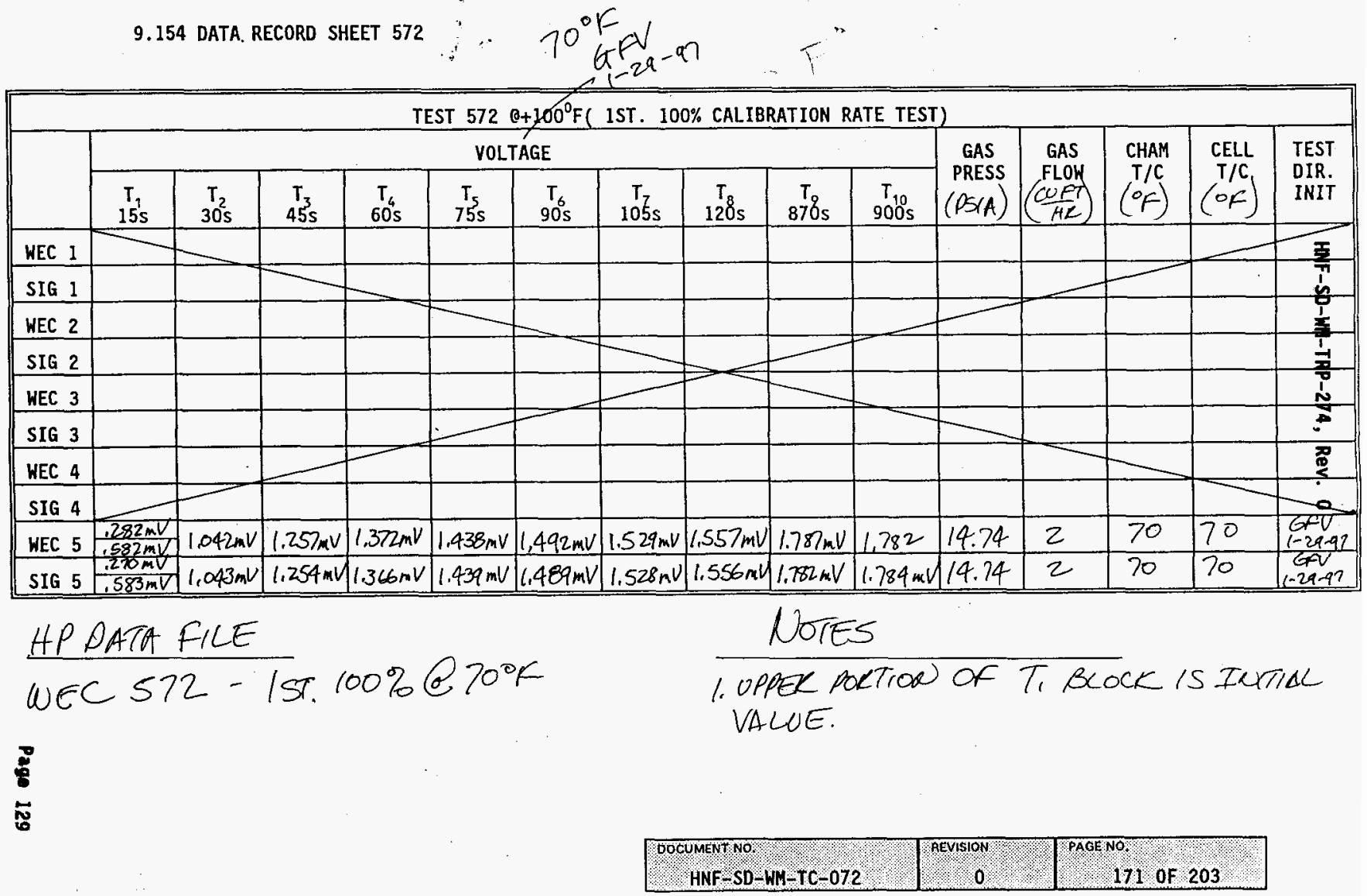


TEST PROCEDURE FOR MEASUREMENT OF PERFORMANCE VS TEMPERATURE WHITTAKER CELL

9.155 DATA RECORD SHEET 573

$\div$

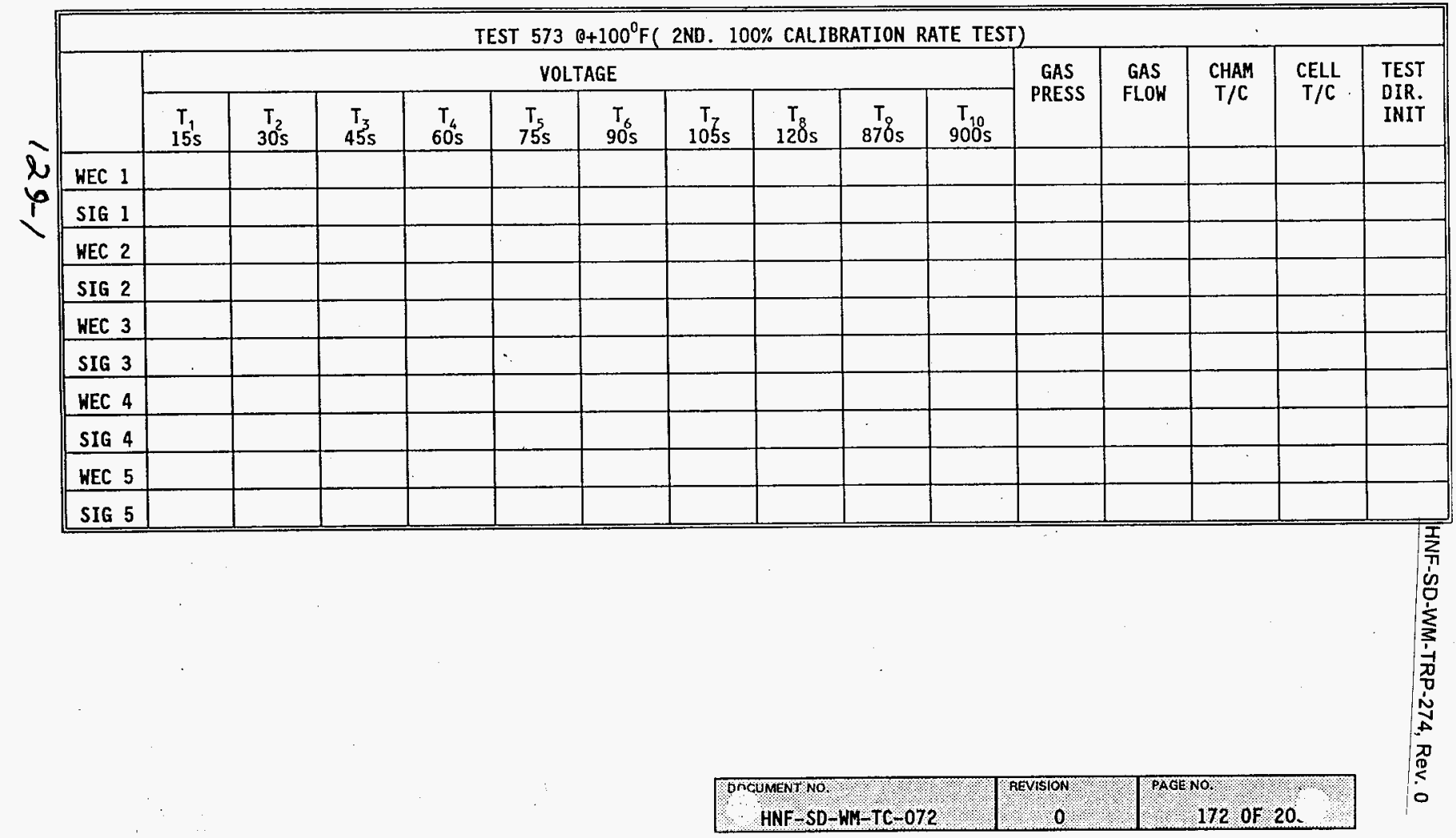


TEST PROCEDURE FOR MEASUREMENT OF PERFORMANCE VS TEMPERATURE

WHITTAKER CELL

9.156 DATA RECORD SHEET $574 \vdots$

\begin{tabular}{|c|c|c|c|c|c|c|c|c|c|c|c|c|c|c|c|}
\hline \multicolumn{16}{|c|}{ TEST $574 @+100^{\circ} \mathrm{F}$ (3RD. $100 \%$ CALIBRATION RATE TEST) } \\
\hline & \multicolumn{10}{|c|}{ VOLTAGE } & \multirow{2}{*}{$\begin{array}{c}\text { GAS } \\
\text { PRESS }\end{array}$} & \multirow{2}{*}{$\begin{array}{l}\text { GAS } \\
\text { FLOW }\end{array}$} & \multirow{2}{*}{$\begin{array}{l}\text { CHAM } \\
\mathrm{T} / \mathrm{C}\end{array}$} & \multirow{2}{*}{$\begin{array}{c}\text { CELL } \\
\mathrm{T} / \mathrm{C}\end{array}$} & \multirow{2}{*}{$\begin{array}{l}\text { TEST } \\
\text { DIR. } \\
\text { INIT }\end{array}$} \\
\hline & $\begin{array}{c}\mathrm{T}_{1} \\
15 \mathrm{~s}\end{array}$ & $\begin{array}{r}T_{2} \\
30 \mathrm{~s} \\
\end{array}$ & $\begin{array}{r}T_{3} \\
45 \mathrm{~s} \\
\end{array}$ & $\begin{array}{r}T_{4} \\
60 \mathrm{~s} \\
\end{array}$ & $\begin{array}{r}T_{5} \\
75 s \\
\end{array}$ & $\begin{array}{r}T_{6} \\
90 \mathrm{~s} \\
\end{array}$ & ${ }_{105 \mathrm{~s}}^{\mathrm{T}_{\mathrm{C}}}$ & $\begin{array}{c}T_{8} \\
12 \delta_{s}\end{array}$ & $\begin{array}{r}\mathrm{T} \\
878 \mathrm{~s} \\
\end{array}$ & $\begin{array}{r}T_{10} \\
900 \mathrm{~s} \\
\end{array}$ & & & & & \\
\hline \multicolumn{16}{|l|}{ WEC 1} \\
\hline \multicolumn{16}{|l|}{ SIG 1} \\
\hline \multicolumn{16}{|l|}{ WEC 2} \\
\hline \multicolumn{16}{|l|}{ SIG 2} \\
\hline \multicolumn{16}{|l|}{ WEC 3} \\
\hline \multicolumn{16}{|l|}{ SIG 3} \\
\hline \multicolumn{16}{|l|}{ WEC 4} \\
\hline \multicolumn{16}{|l|}{ SIG 4} \\
\hline WEC 5 & & & & & & & & & & & & & & & 0 \\
\hline SIG 5 & & & & & & & & & & & & & & & \\
\hline
\end{tabular}

8
5
5 
TEST PROCEDURE FOR MEASUREMENT OF PERFORMANCE VS TEMPERATURE

WHITTAKER CELL

9.157 DATA RECORD SHEET 581

TEST $581+120^{\circ} \mathrm{F}(30 \%, 60 \%, 90 \%$ CALIBRATION GAS $)$

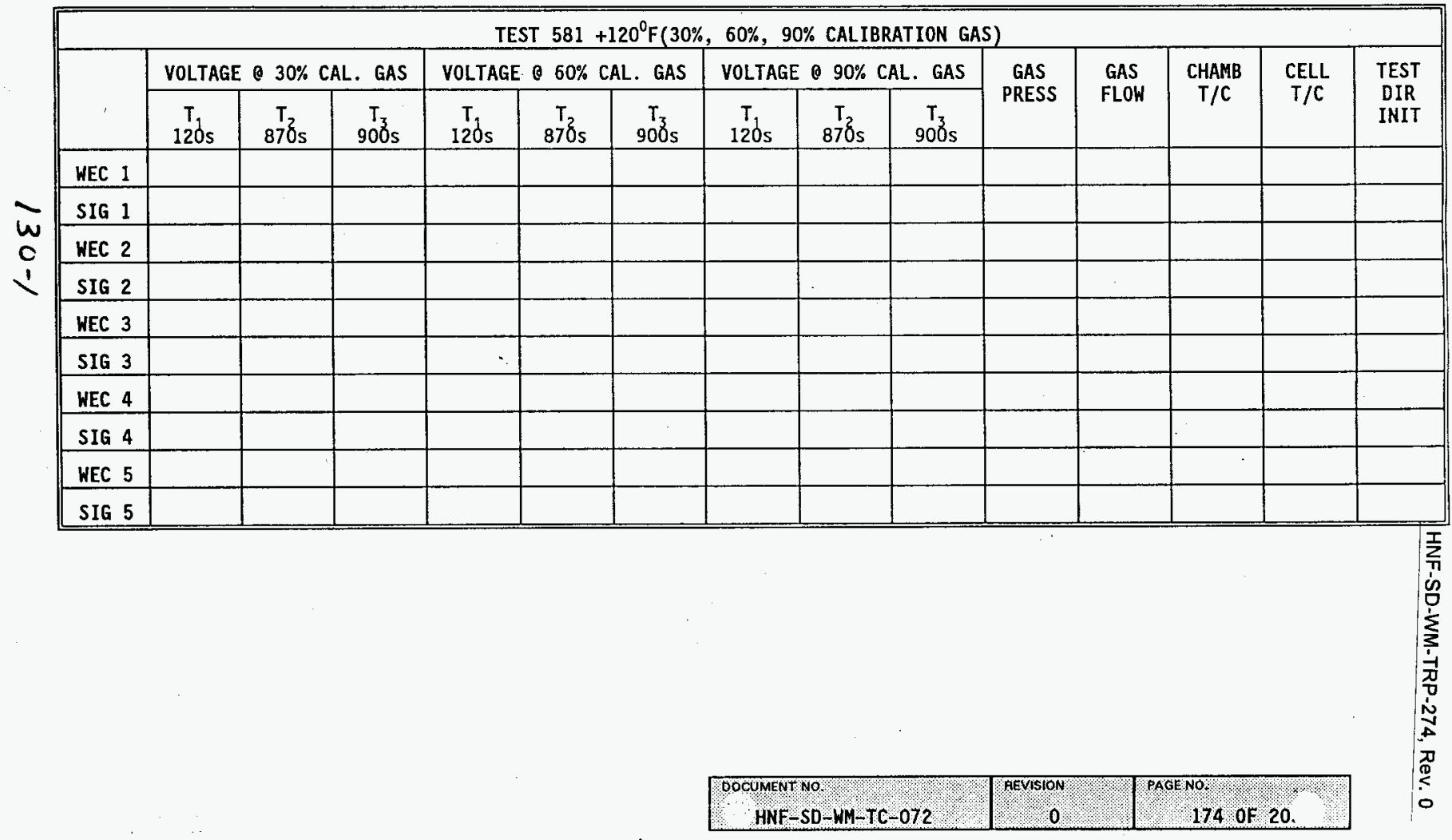


TEST PROCEDURE FOR MEASUREMENT OF PERFORMANCE VS TEMPERATURE

WHITTAKER CELL

9.158 DATA RECORD SHEET 582

\begin{tabular}{|c|c|c|c|c|c|c|c|c|c|c|c|c|c|c|c|}
\hline \multicolumn{16}{|c|}{ IEST $582{ }^{\circ}+120^{\circ} \mathrm{F}$ ( IST. 100\% CALIBRATION RATE TEST) } \\
\hline & \multicolumn{10}{|c|}{ VOLTAGE } & \multirow{2}{*}{$\begin{array}{c}\text { GAS } \\
\text { PRESS }\end{array}$} & \multirow{2}{*}{$\begin{array}{l}\text { GAS } \\
\text { FLOW }\end{array}$} & \multirow{2}{*}{$\underset{\mathrm{T} / \mathrm{C}}{\mathrm{CHAM}}$} & \multirow{2}{*}{$\begin{array}{c}\text { CELL } \\
\mathrm{T} / \mathrm{C}\end{array}$} & \multirow{2}{*}{$\begin{array}{l}\text { TEST } \\
\text { DIR. } \\
\text { INIT }\end{array}$} \\
\hline & $\begin{array}{r}T_{1} \\
15 \mathrm{~s} \\
\end{array}$ & $\begin{array}{r}\mathrm{T}_{2} \\
30 \mathrm{~s} \\
\end{array}$ & $\begin{array}{r}T_{3} \\
45 s \\
\end{array}$ & $\begin{array}{r}\mathrm{T}_{4} \\
600 \mathrm{~s}\end{array}$ & $\begin{array}{c}T_{5} \\
75 \mathrm{~s}\end{array}$ & $\begin{array}{c}T_{6} \\
90 s \\
\end{array}$ & ${ }_{105 \mathrm{~s}}^{\mathrm{T}}$ & $\begin{array}{c}\mathrm{T}_{8} \\
120 \mathrm{~s}\end{array}$ & $\begin{array}{c}T_{\mathrm{o}} \\
87 \% \mathrm{~s}\end{array}$ & $\begin{array}{c}T_{10} \\
900 \mathrm{~s}\end{array}$ & & & & & \\
\hline \multicolumn{16}{|l|}{ WEC 1} \\
\hline \multicolumn{16}{|l|}{ SIG 1} \\
\hline \multicolumn{16}{|l|}{ WEC 2} \\
\hline \multicolumn{16}{|l|}{ SIG 2} \\
\hline \multicolumn{16}{|l|}{ NEC 3} \\
\hline \multicolumn{16}{|l|}{ SIG 3} \\
\hline \multicolumn{16}{|l|}{ WEC 4} \\
\hline \multicolumn{16}{|l|}{ SIG 4} \\
\hline \multicolumn{16}{|l|}{ WEC 5} \\
\hline SIG 5 & & & & & & & & & & & & & & & \\
\hline
\end{tabular}

$\frac{8}{5}$ 
TEST PROCEDURE FOR MEASUREMENT OF PERFORMANCE VS TEMPERATURE

WHITTAKER CELL

9.159 DATA RECORD SHEET 583

\begin{tabular}{|c|c|c|c|c|c|c|c|c|c|c|c|c|c|c|c|}
\hline \multicolumn{16}{|c|}{ TEST $5830+120^{\circ} \mathrm{F}$ ( 2ND. 100\% CALIBRATION RATE TEST) } \\
\hline & \multicolumn{10}{|c|}{ VOLTAGE } & \multirow{2}{*}{$\begin{array}{c}\text { GAS } \\
\text { PRESS }\end{array}$} & \multirow{2}{*}{$\begin{array}{l}\text { GAS } \\
\text { FLOW }\end{array}$} & \multirow{2}{*}{$\begin{array}{c}\text { CHAM } \\
\mathrm{T} / \mathrm{C}\end{array}$} & \multirow{2}{*}{$\frac{\text { CELL }}{\mathrm{T} / \mathrm{C}}$} & \multirow{2}{*}{$\begin{array}{l}\text { TEST } \\
\text { DIR. } \\
\text { INIT }\end{array}$} \\
\hline & $\begin{array}{c}T_{1} \\
15 \mathrm{~s} \\
\end{array}$ & $\begin{array}{c}\mathrm{T}_{2} \\
30 \mathrm{~s} \\
\end{array}$ & $\begin{array}{r}T_{3} \\
45 s \\
\end{array}$ & $\begin{array}{c}T_{4} \\
60 \mathrm{~s} \\
\end{array}$ & $\begin{array}{r}T_{5} \\
75 \mathrm{~s} \\
\end{array}$ & $\begin{array}{c}\mathrm{T}_{6} \\
90 \mathrm{~s}\end{array}$ & $\begin{array}{c}\mathrm{T}_{7} \\
105 \mathrm{~s}\end{array}$ & $\begin{array}{c}T_{8} \\
120 \mathrm{~s}\end{array}$ & $\begin{array}{c}T_{9} \\
870_{\mathrm{s}}\end{array}$ & $\begin{array}{c}T_{10} \\
900 \mathrm{~s}\end{array}$ & & & & & \\
\hline \multicolumn{16}{|l|}{ WEC 1} \\
\hline \multicolumn{16}{|l|}{ SIG 1} \\
\hline \multicolumn{16}{|l|}{ WEC 2} \\
\hline \multicolumn{16}{|l|}{ SIG 2} \\
\hline \multicolumn{16}{|l|}{ WEC 3} \\
\hline \multicolumn{16}{|l|}{ SIG 3} \\
\hline \multicolumn{16}{|l|}{ WEC 4} \\
\hline \multicolumn{16}{|l|}{ SIG 4} \\
\hline \multicolumn{16}{|l|}{ WEC 5} \\
\hline SIG 5 & & & & & & & & & & & & & & & \\
\hline
\end{tabular}




\begin{tabular}{|c|c|c|c|c|c|c|c|c|c|c|c|c|c|c|c|}
\hline & & & & & & & & & & & & & & & S DIS \\
\hline 0 & & & & & & & & & & & & & & & $\mathrm{~S} \mathrm{JMM}$ \\
\hline$>$ & & & & & & & & & & & & & & & $D$ IIS \\
\hline$\approx$ & & & & & & & & & & & & & & & t J3M \\
\hline$\frac{a}{2}$ & & & & & & & & . & & & & & & & E VIS \\
\hline$\underline{\alpha}$ & & & & & & & & & & & & & & & \& J JM \\
\hline$\frac{1}{1}$ & & & & & & & & & & & & & & & 2 פIS \\
\hline 光 & & & & & & & & & & & & & & & 2 JJM \\
\hline 案 & & & & & & & & & & & & & & & I IIS \\
\hline & & & & & & & & & & & & & & & I ग्ग \\
\hline IINI & $3 / 1$ & & & & $\begin{array}{l}\text { Soo6 } \\
0.1\end{array}$ & $50 \angle 8$ & $\begin{array}{l}\text { sozI }_{1} \\
\text { s. }\end{array}$ & squol & $\begin{array}{l}506 \\
91\end{array}$ & $\xi_{1}^{5 g, L}$ & $\begin{array}{l}509 \\
1 \\
1\end{array}$ & $\begin{array}{l}\text { sqt } \\
\varepsilon_{1}\end{array}$ & $\begin{array}{l}\text { Sog } \\
\mathrm{z}_{1}\end{array}$ & $\begin{array}{l}\text { SGI } \\
l_{1}\end{array}$ & \\
\hline $1 S 31$ & כרבר & WHH & SWg & $\begin{array}{c}\text { SHg } \\
\text { SHO }\end{array}$ & \multicolumn{10}{|c|}{$396170 \Lambda$} & \\
\hline
\end{tabular}


TEST PROCEDURE FOR MEASUREMENT OF PERFORMANCE VS TEMPERATURE

WHITTAKER CELL

10.0 APPENDIX C: EXCEPTION RECORD

\begin{tabular}{|c|c|c|c|c|c|}
\hline $\begin{array}{c}\text { EXCEPTION } \\
\text { NUMBER } \\
\text { NUBR }\end{array}$ & $\begin{array}{l}\text { STEP } \\
\text { NUMBER }\end{array}$ & EXCEPTION DESCRIPTION & EXCEPTION RESOLUTION & $\begin{array}{l}\text { RESOLUTION } \\
\text { APPROVED BY: }\end{array}$ & $\begin{array}{l}\text { DATE } \\
\text { RESOLVED }\end{array}$ \\
\hline \multirow[t]{2}{*}{1} & \multirow{2}{*}{6.1 .4} & SYSTEM WIRED TO NEW CAPIG. & AODED ISOLATIOL REZAY & \multirow[t]{2}{*}{$\begin{array}{l}\text { G.F.Vigat: } \\
\text { x.S. wituma: }\end{array}$} & \multirow[t]{2}{*}{$1-25-97$} \\
\hline & & (w) ADOITION of REZAY & BETUEEN WEC'S \& ISB & & \\
\hline \multirow{2}{*}{2} & \multirow{2}{*}{7.4} & TNITAL TEMP CAANBED TO +40,\% & CAIAUGED INITIAL STARTING & \multirow[t]{2}{*}{ G.Fragofi } & \multirow{2}{*}{$1-25-97$} \\
\hline & & PER zlastroctions J.R.Redindon 1-24-97 & TEMNERATEXE TO +40\% & & \\
\hline \multirow{2}{*}{3} & \multirow{2}{*}{$\begin{array}{l}7.19- \\
7.22\end{array}$} & 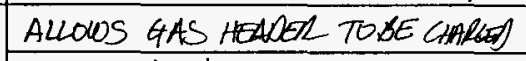 & CAANOEO PRCOEDURE TO ALLOW & \multirow{2}{*}{ G.AVagos } & \multirow{2}{*}{$1-25-97$} \\
\hline & & QUTH 30\%/60\%/90\% GAS TO SOL VALUE & 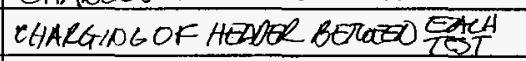 & & \\
\hline \multirow{2}{*}{4} & \multirow{2}{*}{7.32} & CHALCE DOLGE TIME OD & GAANEED STEP 7.32 TIME & \multirow{2}{*}{ GFVanges } & \multirow[t]{2}{*}{$1-25-97$} \\
\hline & & GAS HEADER FROM $15 \mathrm{M}(\mathrm{N})$ TO $2 \mathrm{~m}, \mathrm{~N}$ & FROM 15 MIN TO ZMIN & & \\
\hline \multirow{2}{*}{5} & \multirow{2}{*}{6.1 .4} & SYSTEMI PIPING CHANGED MAOE & CHANGED PIPING CONFIGULATIOO BY & \multirow{2}{*}{ GFVaigof } & \multirow{2}{*}{$1-28-97$} \\
\hline & & EACH WEC VENT INDEPCNDANT & MAKANG EACA WEC VENT SEPERATE & & \\
\hline & & & & & \\
\hline & & & & & $\begin{array}{l}1 \\
i \\
i\end{array}$ \\
\hline & & & & & క̦ \\
\hline & & & & & 㞧 \\
\hline & & & & & I \\
\hline \multirow{3}{*}{\multicolumn{3}{|c|}{11.0 APPENDIX D: TEST RECORD }} & & & \\
\hline & & & & & \\
\hline & & & \begin{tabular}{|c|c|} 
DOCUMENT NO & REVISION \\
HNF-SD-WM-TC-072 & 0 \\
\end{tabular} & $\begin{array}{ll}\text { PAGENO } & \\
178 \text { OF } 2 & \end{array}$ & \\
\hline
\end{tabular}




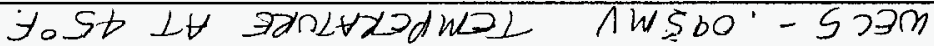

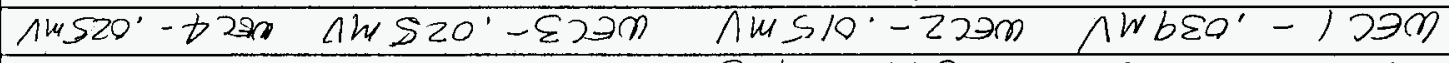

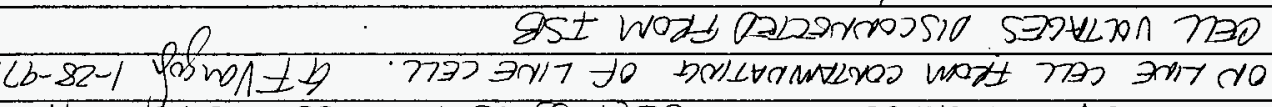

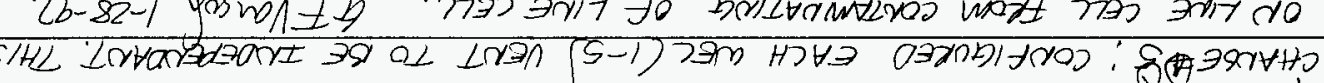

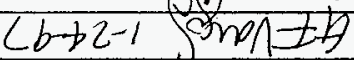

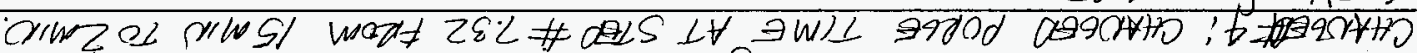

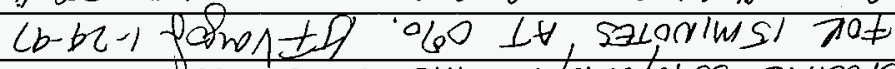

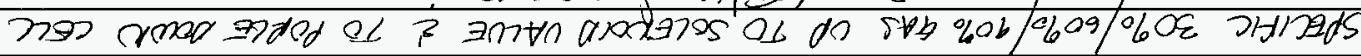

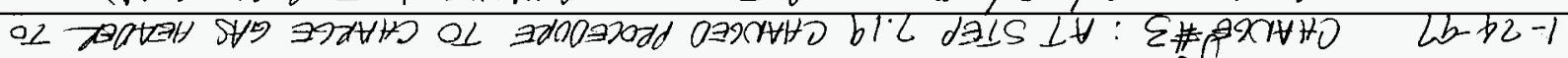
$2 b-b 2-1$ एown \pm 4

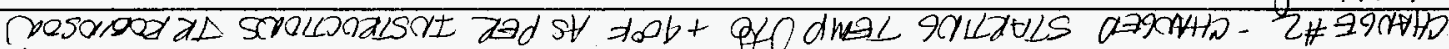
$2 b-b 2-1$

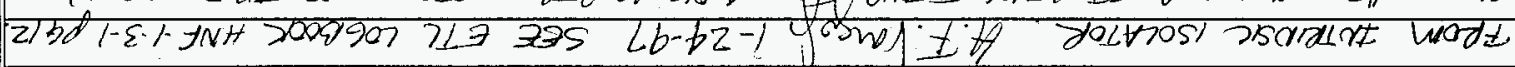

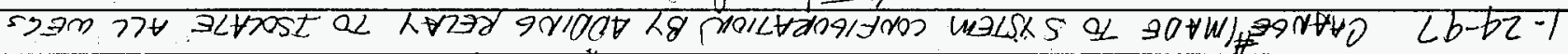


HNF-SD-WIM-TRP-274, Rev. :

TEST PROCEDURE FOR MEASUREMENT OF PERFORMANCE VS TEMPERATURE OF WHITTAKER CELL.

\section{ATTACHMENT 1: FINAL: PROCEDURE ACCEPTANCE SHEET}

Completion of this procedure has demonstrated that:

- The Whittaker electrochemical cell(s), used on the Rotary Mode Core Sampling (RMCS) flammable gas interlock (FGI), to detect and quantify hydrogen gas, have been systematically tested between the temperature ranges of $-20^{\circ} \mathrm{F}$ and $+120^{\circ} \mathrm{F}$. Furthermore, as required by WHC-SD-WM-SAD035 , Section U.3.1 second bullet, a temperature range has been found that the Whittaker cell voltage output(s) have reached $90 \%$ of full scale output, in less than two(2) minutes, when subjected to $100 \%$ calibration gas ( $1 \%$ hydrogen). The temperature range is ${ }^{\circ} \mathrm{F}+/-5^{\circ} \mathrm{F}$ to ${ }^{\circ} \mathrm{F}+/-5^{\circ} \mathrm{F}$.

- A record of all noted deficiencies was kept on Appendix C, Exception Record, and all recorded exceptioins have been resolved and the resolutions approved.

Approved by:

RMCS Exhauster Engineer, E.J. WaTdo

Date

NHC Field Engineering Manager, J.S. Scofield Date

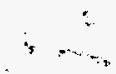




\section{ATTACHMENT 2 \\ TEST PLAN FOR MEASUREMENT OF PERFORMANCE \\ VS \\ TENPERATURE OF WHITTAKER CELL}

REFERENCE: HNF-SD-WM-TP-527, ReV 0

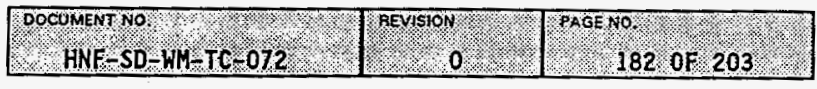

$$
134-\mid
$$




\section{-. To: (Receiving organization) DISTRIBUTION}

5. Proj./Prog./Dept./Div.: CHARACTERIZATION

8. Originator Remarks:

THIS DOCUMENT IS BEING TRANSMITTED FOR APPROVAL AND RELEASE
3. From: (originating organization) REMOTE SENSING AND SAMPLING EQUIPMENT ENGINEERING

6. Cog. Engr.:
E.J. Waldo

4. Related EDT NO.:

N/A

7. Purchase order No.: $N / A$

9. Equip./Component No.: $\mathrm{N} / \mathrm{A}$

10. System/Bldg./Facility: $N / A^{\circ}$

11. Receiver Remarks: THIS TEST CORTTRO CO?

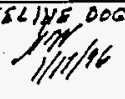

12. Major Assm. Drg. No.: $N / A$

13. Permit/Pernit Application No.: $N / A$

14. Required Response Date: $1 / 13 / 97$

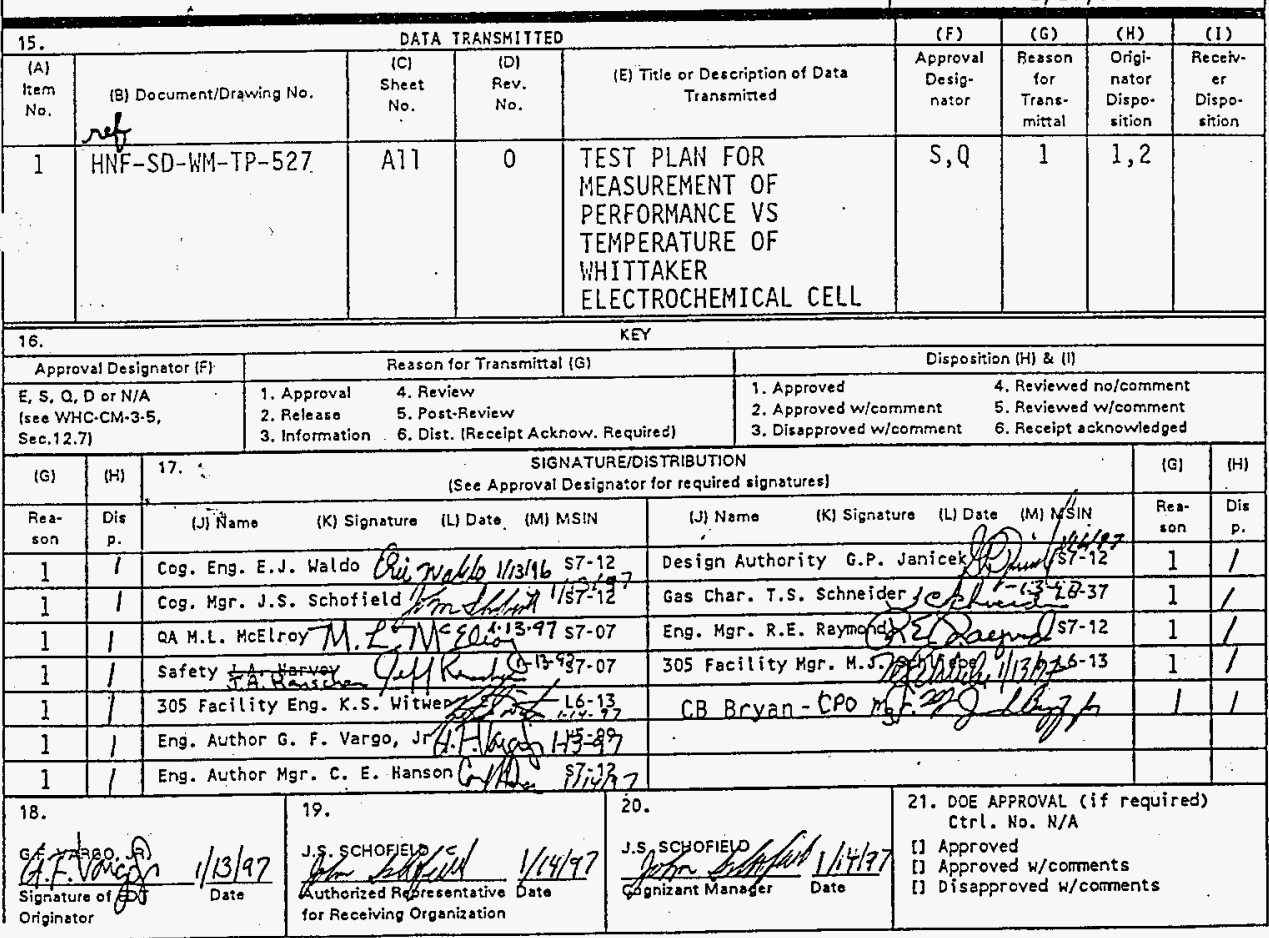

BD-7400-172-2(04/94) GEF097 


$$
\underset{\operatorname{sef}}{H N F-S D-H M-T P-527}
$$

\section{TEST PLAN FOR MEASUREMENT OF PERFORMANCE VS TEMPERATURE OF WHITTAKER \\ - ELECTROCHEMICAL CELL}

G. F. Vargo, Jr. SGN Eurisys Services Corporation, Richland, WA 99352 U.S. Department of Energy Contract DE-ACO6-87RL10930 January 1997

Page 185 of 203 


$$
\begin{aligned}
& \text { of HNF-SD-KM-TP-527 } \\
& \text { Rev } 0
\end{aligned}
$$

\section{TABLE OF CONTENTS}

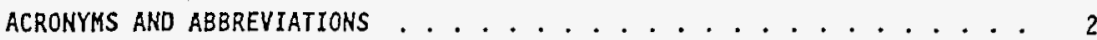

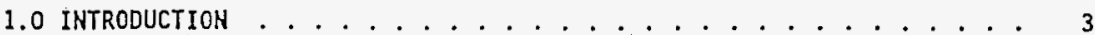

2.0 DESCRIPTION . . . . . . . . . . . . . . . . . . . 3

3.0. REQUIREMENTS . . . . . . . . . . . . . . . . . . . . 5

3.1 GENERAL REQUIREHENTS .................... 5

3.1.1 TEST CONTROLS . . . . . . . . . . . . . . . 5

3.1.1.1 RETEST REQUIREMENTS . . . . . . . . . . . . . 5

3.1.1.2 DEVIATIONS FROK THE TEST PLAN/PROCEDURE . . . . . . . 5

- 3.1.1.2.1 DEVIATIONS FROM THE TEST PLAN ........ 5

3.1.1.2.2 DEVIATIONS FROH THE TEST PROCEDURE ..... .5

3.1.1.3 MEASUREMENT AND TEST EQUIPHENT . . . . . . . . . . 6

3.1.1.4 GAS BOTTLE RECORD............... 6

3.1.1.5 TRAINING ................. . . 6

3.1.1.6 FACILITY IDENTIFICATION ............... . . . 6

3.1.1.7 SAFETY REQUIREKENTS ................ . 6

3.1.1.8 PERSONNEL IDENTIFICATION ............ . . 7

3.1 .1 .9 APPROYAL DESIGKATORS ............. 7

3.1.1.10 TEST PROCEDURES/REVISIONS . . . . . . . . . . 7

4.0 ORGANIZATIONAL RESPONSIBILITIES . . . . . . . . . . . . . 8

4.1 OVERALL CUSTOMER ..................... 8

4.2 REMOTE SENSING AND SAMFLING EQUIPKENT ENGINEERING (RSSEE) • • • 8

4.2.1 TEST DIRECTOR . . . . . . . . . . . . . . . 8

4.3 NUMATEC HANFORD COMPANY (NHC) GAS CHARACTERIZATION . . . . . 8

4.4 NUMATEC HANFORD COMPANY (NHC) 305 ETL . . .......... 9

4.5 NUMATEC HANFORD COHPANY (HHC) FIELD ENGINEERING . . . . . . . . 9

4.5.1 COGNIZAHT RKCS EXHAUSTER ENGINEER . . . . . . . . . 9

5.0 CRITERIA . . . . . . . . . . . . . . . . . . . . 9

5.1 TEST CRITERIA . . . . . . . . . . . . . . . . . 9

5.2 ACCEPTANCE CRITERIA . . . . . . . . . . . . . . . . . 10

6.0 TEST REVIEWS ......................... . . . 10

7.0 TEST DOCUMENTATION . . . . . . . . . . . . . . . . 11

8.0 SCHEDULE .......................... 11

9.0 REFERENCES . . . . . . . . . . . . . . . 12

FIGURE 1 Whittaker Celi Temperature Test Piping Configuration: 13

FIGURE 2 Whittaker Cell Temperature Test Wiring Diagram . . . 14

APPENDIX A Schedule ................. 15

Page 186 of 203 


$$
\begin{gathered}
\text { sif } H N F-S D-W H-T P-527 \\
\operatorname{ReV} 0
\end{gathered}
$$

\section{ACRONYMS AND ABBREVIATIONS}

CPO

DUT

EDT

ETL

FGI

GCS

GMS

- NHC

OSHA

PPM

RMCS

-SHMS

RSSEE

$S D$

$T / C$

WEC
Characterization Project Operations

Device Under Test (Whittaker cell)

Engineering Data Transmittal

Engineering Test Laboratory

Flammable Gas Interlock

Gas Characterization System

Gas Monitoring System

Numatec Hanford Company

Occupational Safety and Health Administration

Parts Per Million

Rotary Mode Core Sampling

Standard Hydrogen Monitoring System

Remote Sensing and Sampling Equipment Engineering

Supporting Document

Thermocouple

Whittaker Electrochemical cell

Page 187 of 203

Page 137 


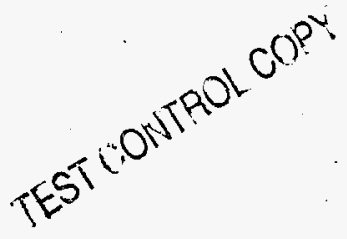

\author{
Nif HNF-SD-KM-TP-527
ReV 0 \\ TEST PLAN \\ FOR KEASUREMENT OF \\ PERFORMANCE VS TEMPERATURE \\ OF WHITTAKER \\ ELECTROCHEMICAL CELL
}

\subsection{INTRODUCTION}

The purpose of this test $p$ lan is to define the methodology used to test the performance of the HEC with changes in temperature. This cell is used on the FGI, for RMCS, to detect and quantify the presence of hydrogen gas - concentration. Since, the WEC on the FGI is not mounted in a protected enclosure, recent calibration of the HEC has been degraded due to the cold. weather.

This test will be performed using the guidelines as defined in EP-4.2, Section 2.2.1, "Development testing". The main purpose of the test is to resolve the engineering issues regarding the performance of the lihittaker cell through the range of temperatures that may be experienced during Hanford Site tank farm deployment. This test will not resolve issues of flow through the HEC. The parameters for the test will be the recommended parameters gained from the experience by the gas characterization team (GCT) while developing the GCSs. The WECs configuration, inlet pressure, and flow rates will not be the same as used during actual use in the FGI system. The test parameters used are best suited to test the response of the HECS to the calibration gas at the test temperatures.

\subsection{DESCRIPTION} Hanford Site, Richland, Washington, using the environmentally controlled test chamber. Five(5) WECS will be placed in the chamber, simultaneously, with the temperature cycled between $-20^{\circ} \mathrm{F}$ and $120^{\circ} \mathrm{F}$. Output will be checked at $20^{\circ} \mathrm{F}$ increments from $-20^{\circ} \mathrm{F}$ to $+120^{\circ} \mathrm{F}$. All voltage outputs shall be recorded at two (2) minutes and at fifteen(15) minutes. The configuration of the WECs will be connected to the intrinsic voltage repeaters replicating the configuration of the FGI.

Each Whittaker cell/intrinsic barrier combination will be tested individualiy a minimum of three times. Only one cell at a time is connected to the carrier and calibration gas system. The 4(four) other cells will be in the chamber and at temperature but will be configured off-line. Each of the 5 (five) WECs will be instrumented with a type $K T / C$ that is individually displayed on a handheld digital thermometer. 


$$
\begin{gathered}
\text { sef } \begin{array}{c}
H N F-S D-H N-T P-527 \\
\text { ReV } 0
\end{array} \\
\text {. }
\end{gathered}
$$

Using $20^{\circ} \mathrm{F}$ increments, the output voltage of the DUT and of the intrinsic voltage repeater will be measured, manualiy, using precision microvoltmeters and then recorded. Also, The T/C temperature output of the digital thermometer attached to the DUT, will be manually recorded. Furthermore, the output voltage, when subjected to three different calibration gas/carrier gas percentages of $30 \%, 60 \%$, and $90 \%$, will be manually recorded. These percentages will be achieved by adjustment of the gas percentage selector switch on the front of the gas divider. This instrument allows the test gas stream to be adjusted varied from $0-100 \%$ calibration gas. by the selector switch.

Also The response, or change in output voltage verses time when subjected to an instantaneous input of $100 \%$ calibration gas, will be manually - recorded. Full scale output shall be defined as the HEC output at 15 minutes.

$\leftarrow$

Other equipment used includes carrier gas bottles of nitrogen( $100 \%$ pure) and calibration gas bottles of hydrogen ( $1 \%$ hydrogen, $99 \%$ others), a precision flow meter, pressure transducer, power supply, and a gas divider. will be used (Reference Figure(s) 1 and 2). The mixture of gas entering the environmental chamber will be equalized to the temperature of the chamber by passage through a 5-10 ft. helix copper coil before entering the DUT.

The instruments will be the same type of instruments as used in the 306 gas characterization laboratory and will be located outside of the test chamber.

The GCS team recommended test values of flow and pressure, by the GCS team, to be used in this test. The flow rates for the measurements in the test chamber will be set to $2 \mathrm{cu} \mathrm{ft}$./hr using the floweter. The pressure input to the DUT will be measured by a precision pressure transmitter to asşure that the cell pressures are consistent during the test.

$A T / C$ and calibrated readout device will be used as the verification instrument to verify the test temperature of the chamber. Furthermore, a computerized data logger will be monitoring and trending the test chamber temperature during all phases of testing.

"Test Procedure for Measurement of Performance vs Temperature of Whittaker Electrochemical Cell", HNF-SD-WM-TC-072, will define the test set-up and testing sequence. This will include the chamber configuration to insure proper venting of the balance and calibration gasses.

All readings will be recorded manually in Appendix $B$ of "Test Procedure for Measurement of Performance vs Temperature of Whittaker Electrochemical Cell", HNF-SD-WM-TC-072. 
HNF-SD-WM-TP-527

Rev 0

\subsection{REQUIREMENTS}

\subsection{GENERAL REQUIREMENTS}

\subsubsection{TEST CONTROLS}

This test shall be conducted under the guidelines set forth in this document. Furthermore; "Test Procedure for Measurement of Performance vs Temperature of whittaker Electrochemical Cell", HNF-SD-WH-TC-072, shall define the sequence of operations.

\subsubsection{RETEST REQUIREMENTS}

Any portion of the test may be re-ran or re-started. However, no previously recorded data shall be destroyed and all data shall be included in the test report. Additionally, it shall be the policy of this test plan to start the test from the beginning of the test sequence and complete the test to the end of the test sequence. All activities for retest shall be at the approval of the test director.

\subsubsection{DEVIATIONS FROM THE TEST PLAN/PROCEDURE}

\subsection{DEVIATIONS FROH THE TEST PLAN}

Deviations are allowed to the test plan if they are approved by the test director, cognizant RMCS exhauster engineer, and the 305 ETL manager, or his designee. The cognizant RMCS exhauster engineer's approval may be acquired by telephorie. Furthermore, any deviations/exceptions, and if approval was acquired by telephone, must be documented in Appendix $C$ of the "Test Procedure for Heasurement of Performance vs Temperature of Whittaker Electrochemical Cel1", HNF-SD-KM-TC-072, and the test report.

\subsection{DEVIATIONS FROH THE TEST PROCEDURE}

Deviations are allowed to the test procedures if they are approved by the test director, cognizant RMCS exhauster engineer, and the $305 \mathrm{ETL}$ manager, or his designee. This approval shall be documented by initialing of the test procedure, by the test director and cognizant engineer, at the appropriate place in the procedure. The cognizant RICS exhauster engineer's approval may be acquired by telephone. However, this shall be noted next to the authorizing initials. Furthermore, any deviations/exceptions must be documented in Appendix $C$ of the "Test Procedure for Measurement of Performance 


$$
\begin{gathered}
\text { sef } \begin{array}{c}
H K F-S D-W H-T P-527 \\
\operatorname{ReV} 0
\end{array} \\
0
\end{gathered}
$$

vs Temperature of Whittaker Electrochemical Ce11", HNF-SD-WM-TC-072, and the test report.

\subsubsection{MEASUREMENT AND TEST EQUTPMENT}

A11 measurement and test equipment shall be in calibration with proof of calibration sticker affixed to the equipment. Furthermore, the sticker shall bear the date calibration expires as well as an authenticating signature or initial. The type, manufacturer, model, measurement and test equipment serial number, and calibration expiration date for each instrument and sensor used in this test sha11 be recorded in Appendix A of "Test Procedure for Measurement of Performance vs Temperature of whittaker Electrochemical Cell", HNF-SD-WHATC-072.

\subsubsection{GAS BOTTLE RECORD}

The pedigree of all gas bottles used in this test shall be documented in Appendix $\mathrm{E}$ of the "Test Procedure for Measurement of Performance vs Temperature of. Whittaker Electrochemical Cell", HNF-SD-WH-TC-072. This shati include the manufacturer, date of manufacturer, type of gas, and concentration in PPM. As part of the supporting documentation a copy of the manufacturers' specification tag/sheet, for any bottle used, shall be included in the test report.

\subsubsection{TRAINING}

Training sha7l be given to the testing personnel pertaining to the operation of the environmental chamber. This training shall be provided by the 305 ETL cognizant engineer or his representative. A record of the personnal shall be maintained, on file, by the 305 . ETL cognizant engineer. A copy of this record shall be attached to the test report. No other training is required.

\subsubsection{FACILITY IDENTIFICATION}

The testing facility shall be the 305 ETL, 300 area, Hanford site, Richland, Washington. The environmental chamber is located in this facility.

\subsubsection{SAFETY REQUIREMENTS}

The 305 ETL cognizant engineer shall instruct the testing personnel, pertaining to safety, within the $305 \mathrm{ETL}$ as well as safety practices pertaining to operation of the environmental chamber. Ail personnel, present

\section{Page 191 of 203




$$
\begin{gathered}
\text { sef HNF-SD-KM-TP-527 } \\
\operatorname{ReV} 0
\end{gathered}
$$

during testing in the $305 \mathrm{ETL}$, shall abide by these requirements. These include:

- wearing of OSHA approved eye protection at ail times

- wearing of OSHA approved hardhat protection when crane operations are overhead

- utilizing the "buddy system" when performing work in the facility. follows:

\subsubsection{PERSONNEL IDENTIFICATION}

The key personnel identified for the performance of this task are as
$\therefore \quad$ Test responsible engineering manager: C. E. Hanson
- 305 ETL responsible manager: M. J. Schliebe
- Cognizant RMCS exhauster engineer: E. J. Waldo/J. D. Robinson
- Cognizant 305 ETL engineer: K. S. Witwer
- Test Director: G. F. Vargo, Jr.
other support personnel shall be supplied, as necessary, from 305 ETL or RSSEE.

\subsubsection{APPROVAL DESIGKATORS}

As a minimum, this test plan shall be approved by Lockheed Martin Hanford Company Design Authority, Qual ity Assurance, Industrial Safety, Numatec Hanford 305 ETL engineer, and technical peer review. The personnel assigned for the peer review shall be as designated by the cognizant RMCS exhauster engineer. They include the NHC Cognizant Engineer and Cognizant Manager. These approvals and reviews shall be authenticated by signature on the EDT for this plan.

\subsubsection{TESTT PROCEDURES/REVISIONS}

"Test Procedure for Measurement of Performance vs Temperature of Whittaker Electrochemical Cell", HNF-SD-WM-TC-072, defines the test sequence and test order. It is the intent of this plan that the test procedure be followed to complete the test: under the test criteria defined in Section 5. However, the test setup, sequence, or test order may be changed with the approval of the cognizant RMCS exhauster engineer, the test director, and the 305 ETL manager, or his designee See Section 3.1.1.2

Page 192 of 203

\section{(39-)}




$$
\begin{gathered}
\text { sef } H N F-S D-W H-T P-527 \\
\operatorname{ReV} 0
\end{gathered}
$$

\title{
4.0 ORGANIZATIONAL RESPONSIBILITIES
}

\subsection{OVERALL CUSTOMER}

The overall customer for this test is the Lockheed Martin Hanford Characterization Project CPO. The responsible engineering organization, for RMCS, is Lockheed Numatec Hanford Company. The exhauster, and supporting flammable gas interlock, supports RMCS.

Characterization Project Cognizant Manager: Program Manager(NHC):
M. A. Payne

R. E. Raymond

\section{- 4.2 REMOTE SENSING AND SAMPLING EQUIPHENT ENGINEERING (RSSEE)}

The RSSEE organization will be responsible for the test. This includes the generation of the test $p l a n$, test procedures, test report, execution of the test in the $305 \mathrm{ETL}$, and interface with the $305 \mathrm{ETL}$ engineering and management personnel.

Manager:

Test Director: Cognizant RMCS exhauster engineer(alternate): Supporting Personne?:
C. E. Hanson

G. F. Vargo, Jr.

J. D. Robinson

As Required

\subsubsection{TEST DIRECTOR}

The test director will be responsible for all interface to perform the test. This includes the generation of the test plan, test procedures, test report; minutes of the pre-test meeting in the 305 ETL minutes of the design review,-expediter for all document signature reviews/approvals, execution and direction of the test, and all signature and $\log$ entries to the procedure.

\subsection{NUMATEC HANFORD COMPANY (NHC) GAS CHARACTERIZATION}

NHC will be responsible to assist RSSEE in the preparation of the test plan, test procedures, and the test setup. Additionally, NHC will be available as consultants in the matters of gas characterization and analysis.

\author{
Manager: H. C. Miller \\ Supporting Engineer: T. C. Schneider
}




$$
\text { rof } \begin{gathered}
H N F-S D-W M-T P-527 \\
\operatorname{ReV} 0
\end{gathered}
$$

\subsection{NUMATEC HANFORD COMPANY (NHC) 305 ETL}

NHC is the custodian of the 305 ETL. They will be responsible to assist RSSEE in the preparation of the test plan, test procedures, assist the test director in the execution of the test, 305 ETL building safety training and orientation, technician support, and the test setup. This will include the supplying of $T / C s$ for the WECs and test instrumentation.

$$
\begin{aligned}
\text { Manager: } & \text { M. J. Schiliebe } \\
\text { Facility Cognizant Engineer: } & \text { K. S. Hitwer }
\end{aligned}
$$

\subsection{NUMATEC HANFORD COMPANY (NHC) FIELD ENGINEERING}

ANHC field engineering will be responsible for use of the FGI in the field. The cognizant RMCS exhauster engineer will be from this organization.

$$
\begin{array}{cl}
\text { Manager: } & \text { J. S. Schofield } \\
\text { Cognizant RMCS Exhauster Engineer: } & \text { E. J. Waldo }
\end{array}
$$

\subsubsection{COGNIZANT RMCS EXHAUSTER ENGINEER}

The cognizant RlYCS exhauster engineer will have the overall responsibility of the test. has the overall technical responsibility for the exhauster field equipment. For this testing he will have signature approval of all test documentation and test changes or deviations. designator authority for peer reviewers, and the final authority on any aspects of the test.

An alternate cognizant RMCS exhauster may be used. This engineer will be suplied from Remote Sensing and Sampling Equipment Engineering (RSSEE).

\subsection{CRITERIA}

This equipment is intended to operate in the temperature range of $10^{\circ} \mathrm{F}$ to $100^{\circ} \mathrm{F}$. However, for purposes of this test, the temperature range beyond the expected temperature range of operation shall be incorporated.

\subsection{TEST CRITERIA}

- The test apparatus configuration shall be such that the test pressure at the WEC under test shall remain within $+/-2 "$ W.C., of atmospheric pressure, during the test.

- Voitage output of WEC(s) shall be 1 inear at the three(3) different hydrogen gas concentrations. Output will be checked at $20^{\circ} \mathrm{F}$ increments from $-20^{\circ} \mathrm{F}$ to $+120^{\circ} \mathrm{F}$. All voltage outputs shall be recorded at. two (2) 


\section{sof $H N F-S D-K M-T P-527$
$\operatorname{ReV} 0$}

minutes and at fifteen(15) minutes.

- Voltage output of $\mathrm{KEC}(s)$, when instantaneously subjected to $100 \%$ calibration gas ( $1 \%$ hydrogen), shall reach $90 \%$ of full scale output voltage in less than two(2) minutes. after checking at $20^{\circ} \mathrm{F}$ increments from $-20^{\circ} \mathrm{F}$ to $+120^{\circ} \mathrm{F}$. The voltage outputs/inputs shall be recorded at two(2) minutes and at fifteen(15) minutes.

- Voltage output verses voltage input of the intrinsic isolating voltage repeater(s) $9323 / 10-10-11$ shall be the same value $(+/-.1 \%)$ after checking at $20^{\circ} \mathrm{F}$ increments from $-20^{\circ} \mathrm{F}$ to $+120^{\circ} \mathrm{F}$. The voltage outputs/inputs shall be recorded at two(2) minutes and at fifteen(15) minutes.

- Voltage output from the $H E C(s)$ shall be repeatable within $+1-10 \%$, for a repetition of the same test. At a minimum three(3) identical tests shall be performed on each WEC.

- The WEC output at 14 minutes 30 seconds shall be $99.9 \%$ of the WEC output at 15 minutes.

In the event that these criteria cannot be met at all temperatures the same criteria shall be used to identify that temperature range, within $+1-$ $5^{\circ} \mathrm{F}$, that will allow each $\mathrm{WEC}$ to meet acceptance criteria.

\subsection{ACCEPTANCE CRITERIA}

The WEC under test, when instantaneously subjected to $100 \%$ calibration gas ( $1 \%$ hydrogen), shali have a response time requirement of reaching $90 \%$ of full scale output voltage in less than two(2) minutes at all temperatures tested: Reference SAD-035, Section V.31 second bullet. See Section 9.0 of this dooument.

While operating in the temperature range determined bythese test results the criteria in Section 5.1 , the WEC shall reach $90 \%$ of full-scale output within two minutes, as required by WHC-SD-WM-SAD-035.

\subsection{TEST REVIEHS}

After the test $p l a n$ and test procedures have been generated and released a meeting will be held to review the plan, procedures, design, safety, quality assurance (QA), setup, and overall test configuration before initiation of the test. Meeting minutes will document the results. These minutes will be included in the test report.

During the test execution there will be two(2) technical peer, QA, and safety reviews that will be visits to the test location in the 305 ETL. The

Page 195 of 203 


$$
\begin{aligned}
& \text { sef } H N F-S D-W M-T P-527 \\
& \text { ReV } 0
\end{aligned}
$$

results of these reviews will be entered in Appendix 0 of the "Test Procedure for Measurement of Performance vs Temperature of Whittaker Electrochemical Cell", HNF-SD-WM-TC-072 by the test director. These reviews will be selected at random and spaced accordingly (See attached schedule), to ensure that the execution of the test is in accordance with the plan and the procedures. The personnel to perform these reviews will be identified by the cognizant RMCS exhauster engineer during the pretest meeting.

\subsection{TEST DOCUMENTATION}

The documentation for this test will consist of the following:

$$
\begin{array}{lll}
* \quad \text { - } \quad \text { Test plan } \\
\quad \text { - Test procedures } \\
\end{array}
$$

The test procedure will contain a Test Log (Appendix D) that will $70 \mathrm{~g}$ events pertaining to the test. This section will substitute for the keeping of a separate test $\mathrm{log}$. Entries to this section will be entered only by the test director.

\subsection{SCHEDULE}

SEe APPENDIX A.

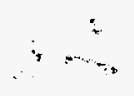

Page 196 of 203

$$
|4|-1
$$


sof HNF-SD-HM-TP-527
ReV 0

\subsection{REFERENCES}

WHC-CM-6-1, Standard Engineering Practices, EP-4.2, Testing Requirements, Westinghouse Hanford Company, Richland, Washington, July 31, 1996.

WHC-SD-Wli-SAD-035, A Safety Assessment of Rotary Mode Core Sampling in Flammable Gas Single Shell Tanks, Rev OA, Los Alamos National Laboratory, Los Alamos, New Mexico, August 1996. 
HNF-SD-WM-TC-072, Rev

$$
\begin{gathered}
\text { sef } \begin{array}{c}
H N F-S D-W M-T P-527 \\
\operatorname{ReV} 0
\end{array} \\
0
\end{gathered}
$$

FIGURE 1

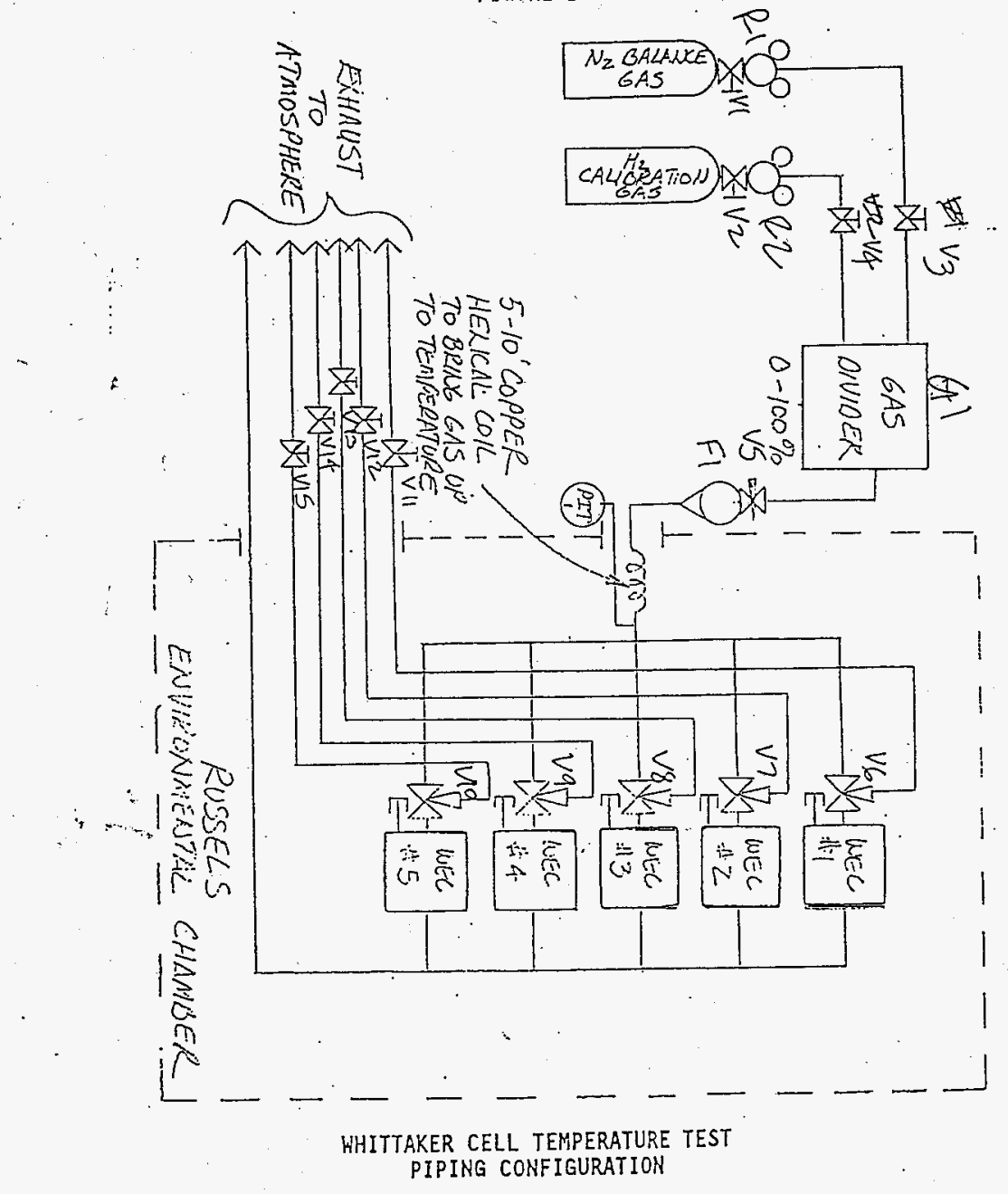

Page-198 of 203 
Attachment 2

HNF-SD-WM-TC-072, Rev 0

HWF-SD-IM-TRP-274, Rev. 0

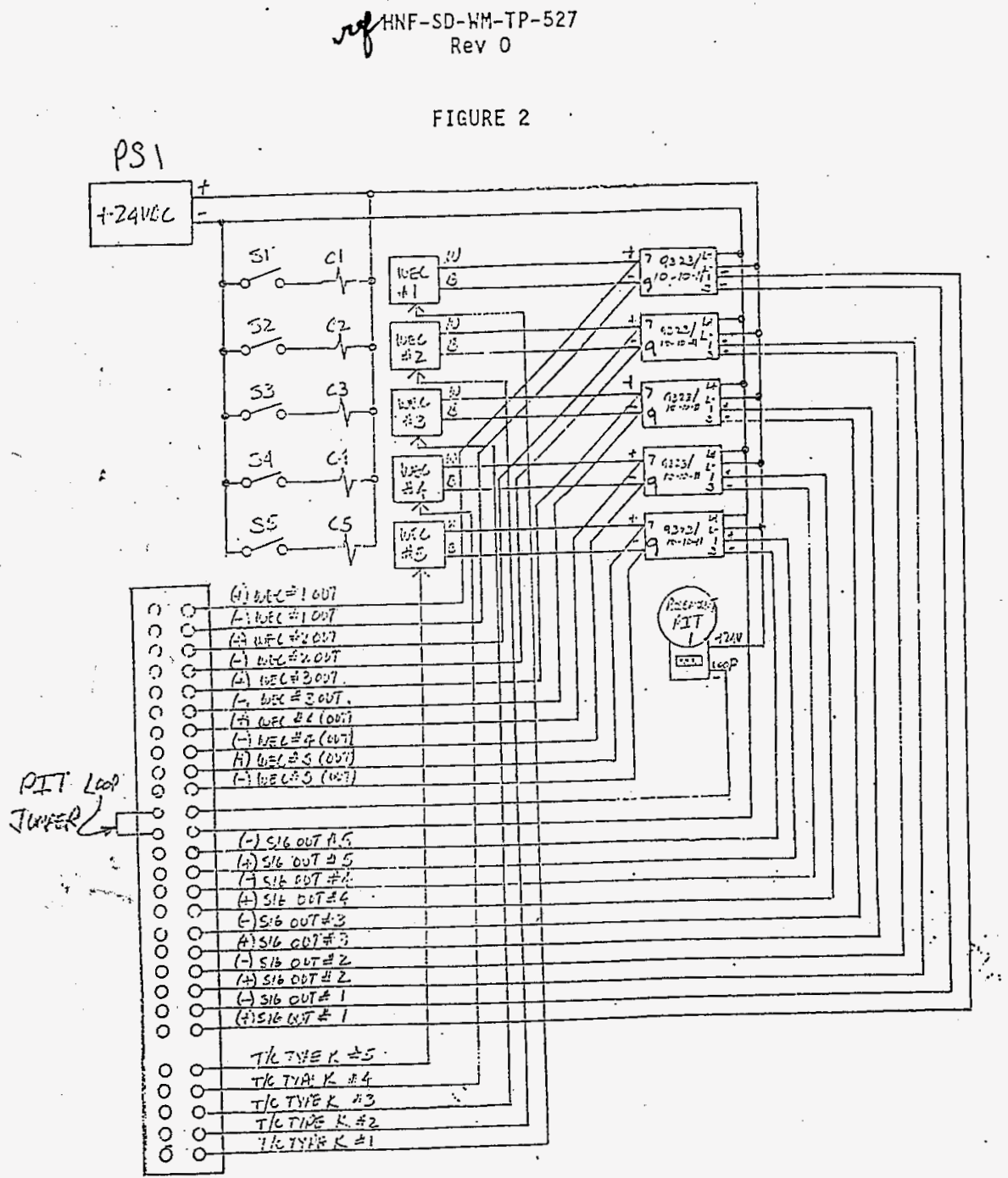

HHITTAKER CELL TEMPERATURE TEST

HIRING DIAGRAM.

Page 199 of 203 
nef HiNF-SD-KM-TP-527
ReV 0

\section{APPENDIX A}

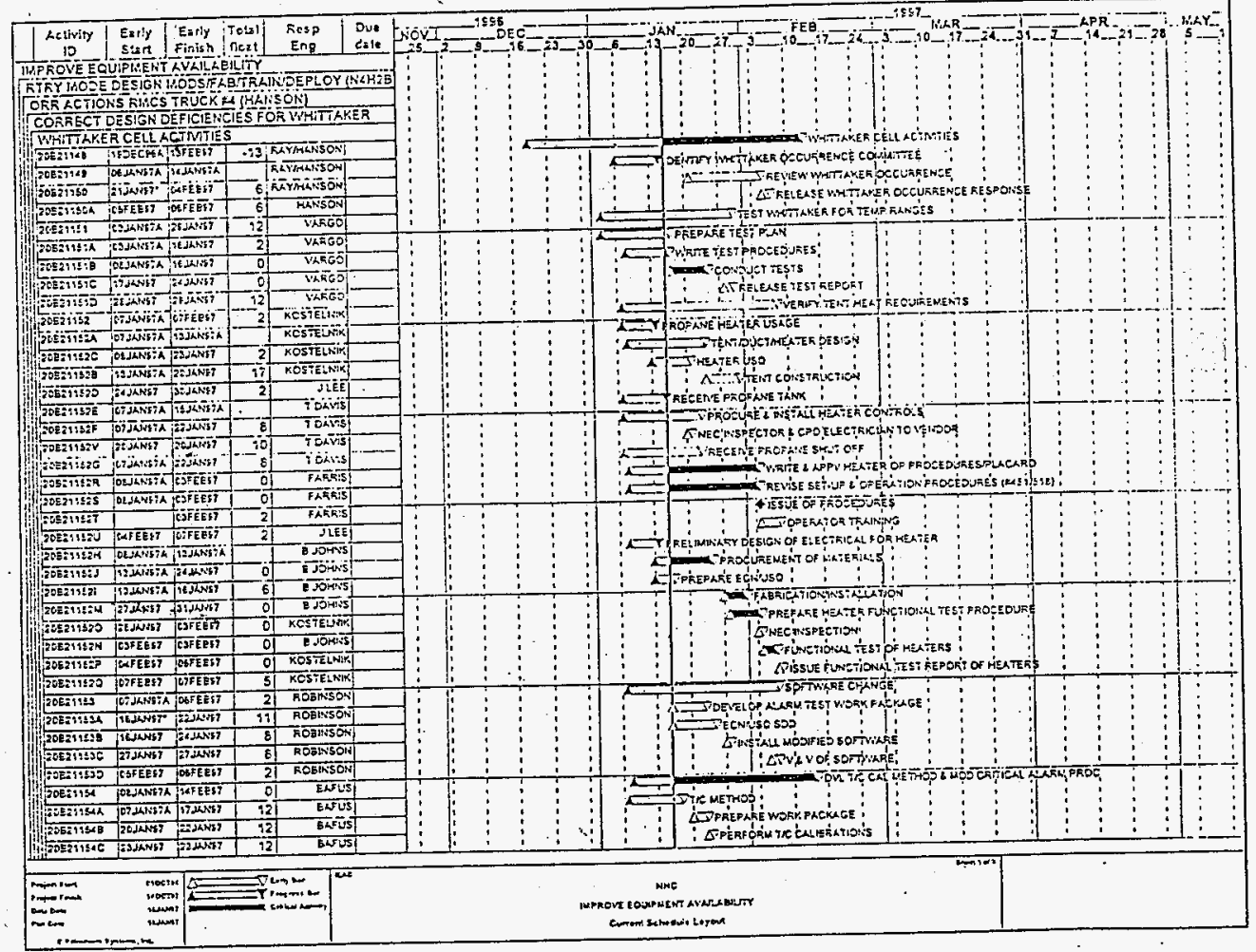


ref $H W F-S D-W H-T P-527$
$\operatorname{ReV} 0$

\section{APPENDIX A}

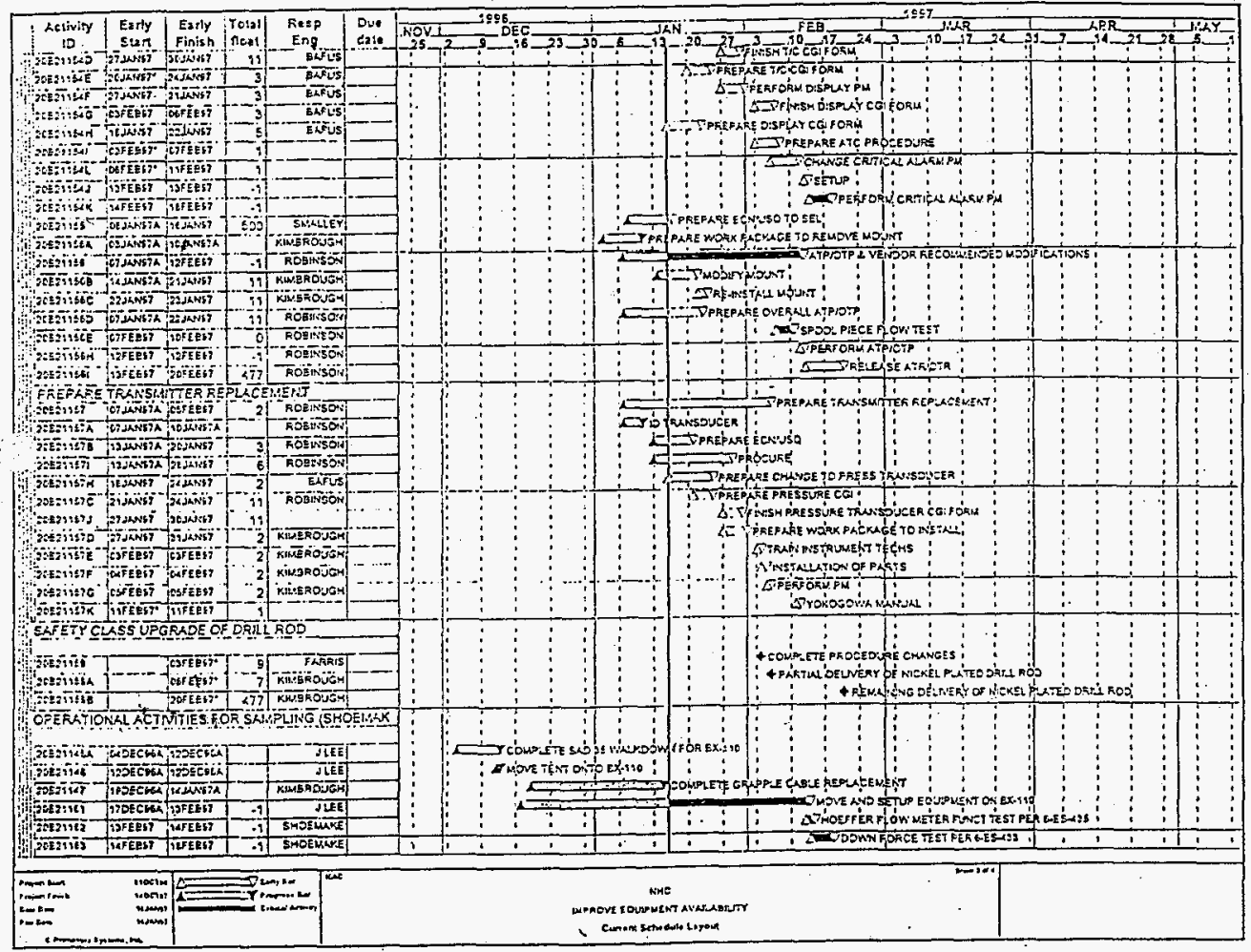

Page 201 of 203 
- Attachiment 2

HNF-SD-WM-TC-0.72, Rey 0

HNF-SD-WM-TRP-274, Rev. 0

nefHKF-5D-WH-TP-527
ReV 0

APPEHDIX A

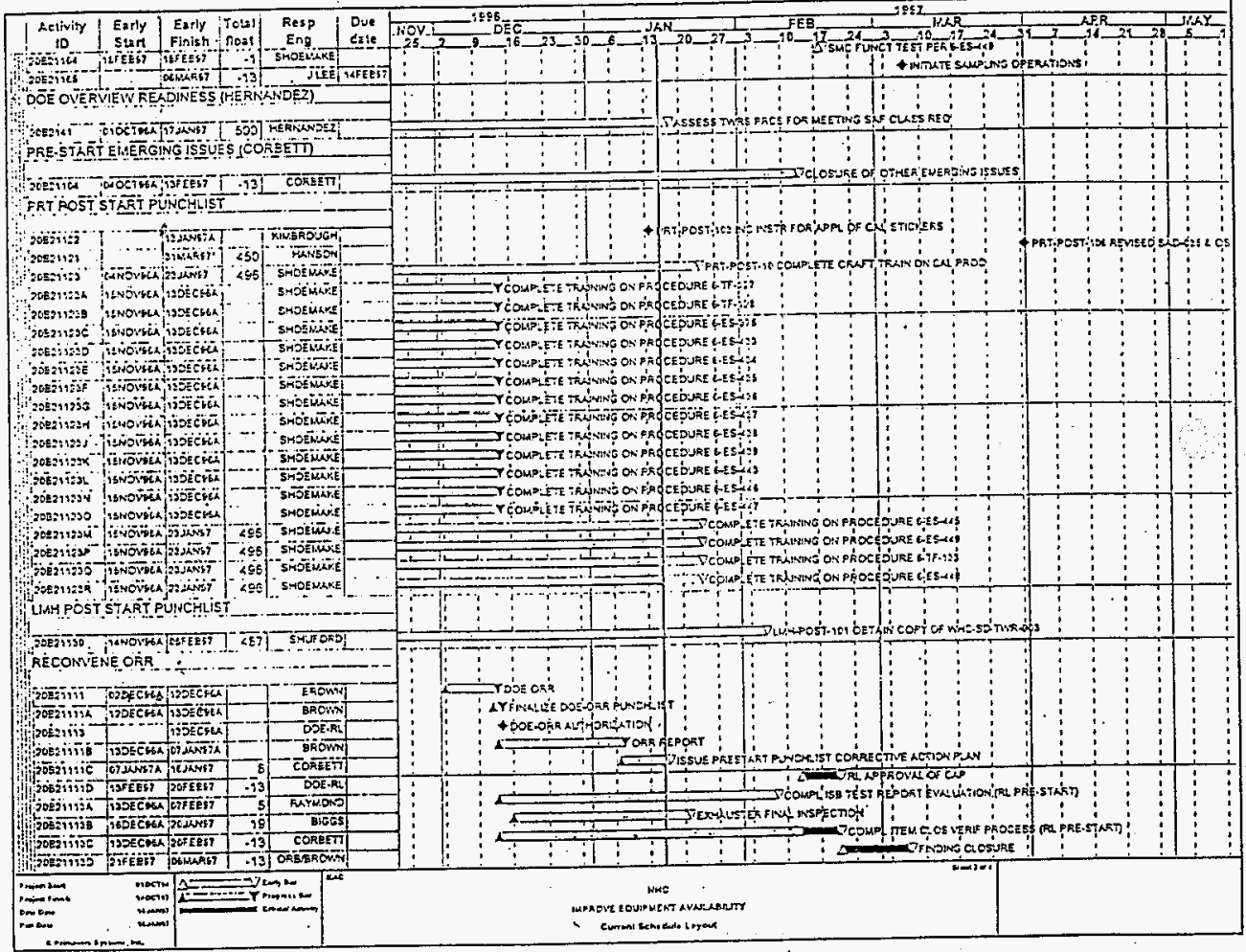


Attachinent 2

HNF-SD-WM-TC-07.2, ReV 0

finF-SD-KH-TP-527
Rev 0 i

\section{APPENDIX A}

Activity Earty

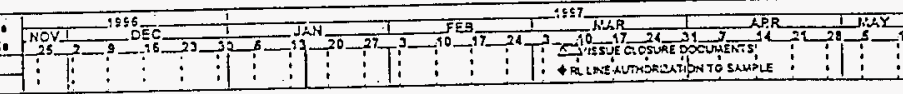


THIS PRE: INTENTIONALLY LEFT BLANK 
HNF-SD-WM-TRP-274

Rev 0

\subsection{ATTACHMENT 5: SUPPORTING DOCUMENTATION}

Page 146 
THIS PAGE INTENTIONALLY LEFT BLANK 
HNF-SD-HM-TRP-274, Rev. 0

\section{HANFORD JOB HAZARD ANALYSIS CHECKLIST}

Frepared By Keith S. Witwer

\begin{tabular}{|l|l|}
\hline Date $01 / 20 / 97$ & Area \\
\hline perature of Whittaker
\end{tabular}

300

Page 1 of 3

icope/Description: Measurement of Performance Vs. Temperature of Whittaker Electro--

chemical Cel1. (Using Russelis Environmental Chamber)Per attached

Test Plan HNF-SD-WM-TP-527 and Test Procedure HNF-SD-WM-TC-072

Emergency Contact Person(s):

Primary: Keith S. Witwer - Numatec Hanford Co.

Secondary: Eric Nelson - Industrial Safety contact-Fluor Daniel Hanford. Inc

Emergency Radio/Phone Number: 911

Specific Work Location(s): 305 Building North High Bay: In and around Environmental Chamber

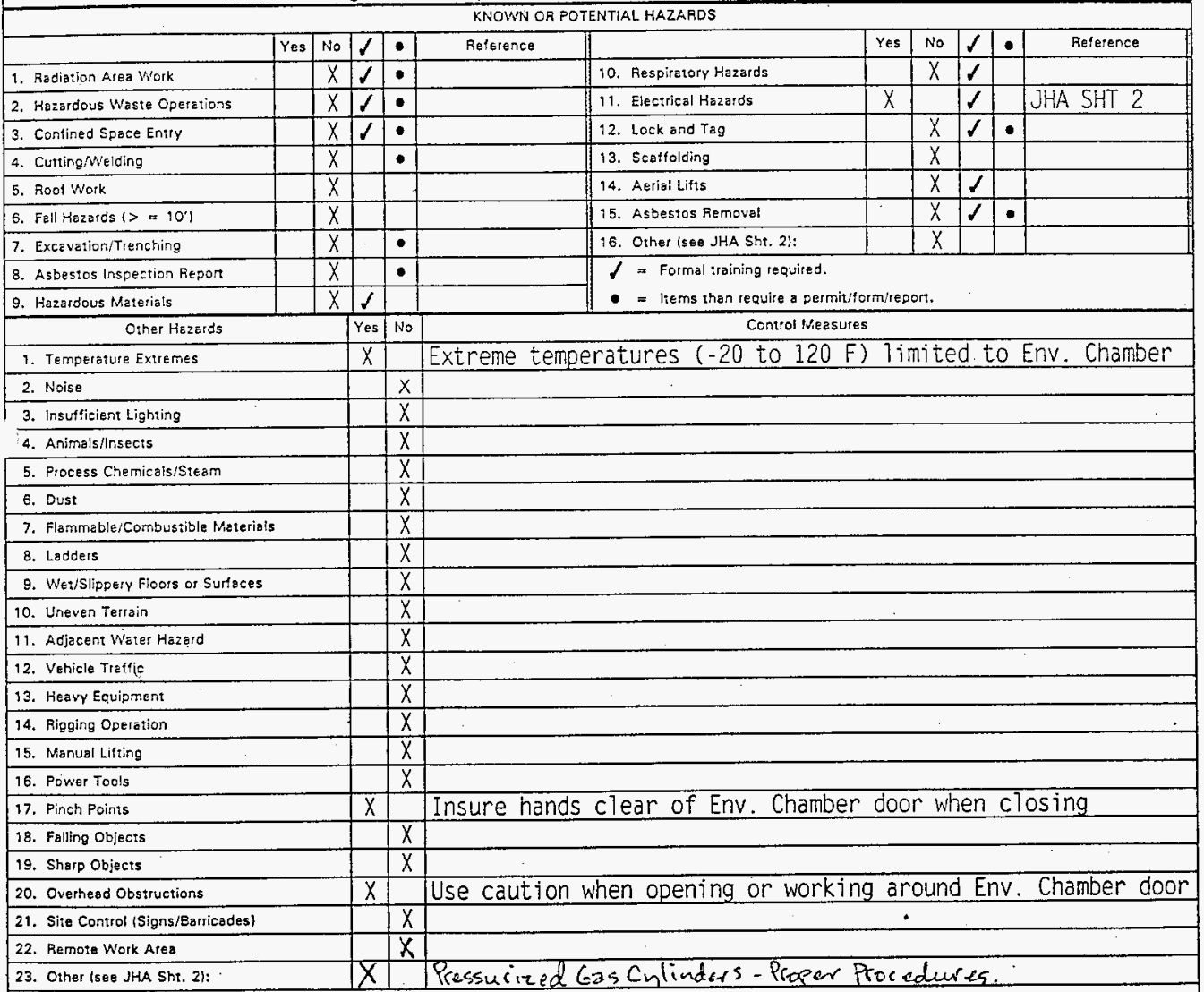

MinIMUM dRESS REQUIREMENTS: LAB COAT, LEATHER GLOVES IF TOUCHING HOT/COLD ITEMS IN CHAMBER

$X$ If further evaluation of the job steps, associated hazerds, or safety measures need to be performed, continue job hazard snalysis on pege 2 .

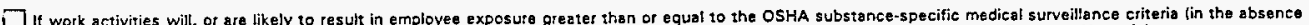
of such critieria, use the lower of one-half the OSHA PEL of one-half the ACGIH), complete Site Form A-6001-981 (Potential Exposure Hozards). of such critieria, use the lower of One-half the OSHA PEL of One-half the ACGIH, comple

Supervisor, Person in Charge MICHEAL J
(Signarure) APPROVALS

Industrial Safety/Hygiene ERIC NELSON
(Signatutelsl)

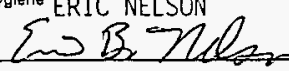

Page 147 
THIS PAGE INTENTIONALLY LEFT BLANK 


\begin{tabular}{|c|c|c|}
\hline \multicolumn{3}{|c|}{ HANFORD JOB HAZARD ANALYSIS (Continuation Sheet) } \\
\hline $\begin{array}{c}\text { Sequence of Basic Job Steps } \\
\text { or Work Activity }\end{array}$ & Hazards Present & How to Eliminate Hazards \\
\hline $\begin{array}{l}1.0 \text { Pre-startup: } \\
\text { Configuration and Assembly of Test } \\
\text { Apparatus }\end{array}$ & $\begin{array}{l}\text { A)Control Voltages (24vdc) } \\
\text { B)Equipment Line Voltages (110vaC) } \\
\text { C)Pressurized Gas Cylinders } \\
\text { D)Environmental Chamber door }\end{array}$ & $\begin{array}{l}\text { A) Insure power off when making connections } \\
\text { to equipment. } \\
\text { B) Insure power cords are in good condition } \\
\text { and insure no standing water near cord. } \\
\text { C) Use proper gas cylinder procedure when } \\
\text { moving/storing cylinders. Use proper } \\
\text { cylinder holders when stored. } \\
\text { D) Use caution when opening large door and } \\
\text { insure others working nearby are aware of } \\
\text { door opening/closing. }\end{array}$ \\
\hline 2.0 Startup sequence & $\begin{array}{c}\text { Pressurized gas (inert) } \approx 1500 \text { PSI } \\
\text { - Calibration Gas is } 10 \% \mathrm{H}_{2} \mathrm{~A} \\
99010 \text { Air } \\
\text { - Carrier Gas is } 100 \% \mathrm{~N}_{2}\end{array}$ & $\begin{array}{l}\text { Verify per Test Procedure HNF-SD-WM-TC-072 } \\
\text { (attached) that appropriate valves on } \\
\text { cylinder regulators are set properly. Also } \\
\text { verify position of vent valves before } \\
\text { starting test. }\end{array}$ \\
\hline 3.0 Operations sequence & Temperature Extremes & $\begin{array}{l}\text { If adjustment of items inside environmental } \\
\text { chamber is necessary. use leather gloves } \\
\text { when temperature is above } 100^{\circ} \mathrm{F} \text { or below } \\
32^{\circ} \mathrm{F} \text {. }\end{array}$ \\
\hline 4.0 Shutdown sequence & Pressurized Gas & $\begin{array}{l}\text { Insure gas cylinder are properly closed } \\
\text { before disconnecting gas lines }\end{array}$ \\
\hline
\end{tabular}


THIS PAGE INTENTIONALLY

LEFT BLANK 


\begin{tabular}{|c|c|c|c|}
\hline \multicolumn{3}{|c|}{ HANFORD JOB HAZARD ANALYSIS (Continuation Sheet) } & Page 3 of 3 \\
\hline $\begin{array}{c}\text { Sequence of Basic Job Steps } \\
\text { or Work Activity }\end{array}$ & Hazards Present & \multicolumn{2}{|c|}{ How to El iminate Hazards } \\
\hline 5.0 Emergency procedures & $\begin{array}{l}\text { A)Oven Malfunctions } \\
\text { B)Gas line leak } \\
\text { C)Gas cylinder rupture }\end{array}$ & \multicolumn{2}{|c|}{$\begin{array}{l}\text { A)Frequently monitor internal chamber } \\
\text { temperature - if temperature control is } \\
\text { lost, then disconnect power and } \\
\text { troublshoot. } \\
\text { B)Frequently monitor gas flow - if } \\
\text { excessive flow is observed - shut off gas } \\
\text { supply } \\
\text { C) Mount cylinder in position where } \\
\text { catastrophic failure cannot harm personnel } \\
\text { - call g1l if accident occurs. }\end{array}$} \\
\hline 6.0 Cleanup and dismantling. & $\begin{array}{l}\text { A)Damage to Pressurized Gas cylinder } \\
\text { when moving to cylinder dock. } \\
\text { B)Electrical hazards }\end{array}$ & \multicolumn{2}{|c|}{$\begin{array}{l}\text { A)Use proper gas cylinder handling } \\
\text { procedure } \\
\text { B)Power down equipment before dismantling. }\end{array}$} \\
\hline
\end{tabular}

ह 


\section{THIS PAGE INTENTIO
LEFT BLANK}


Meeting Description Pre Job Meeting for Whittaker Cell Temperature Testing

Results Desired Insure attendees are aware of hazards. control points, site safety info, etc.

Date 01/24/97

Time Location ETL Conference Room

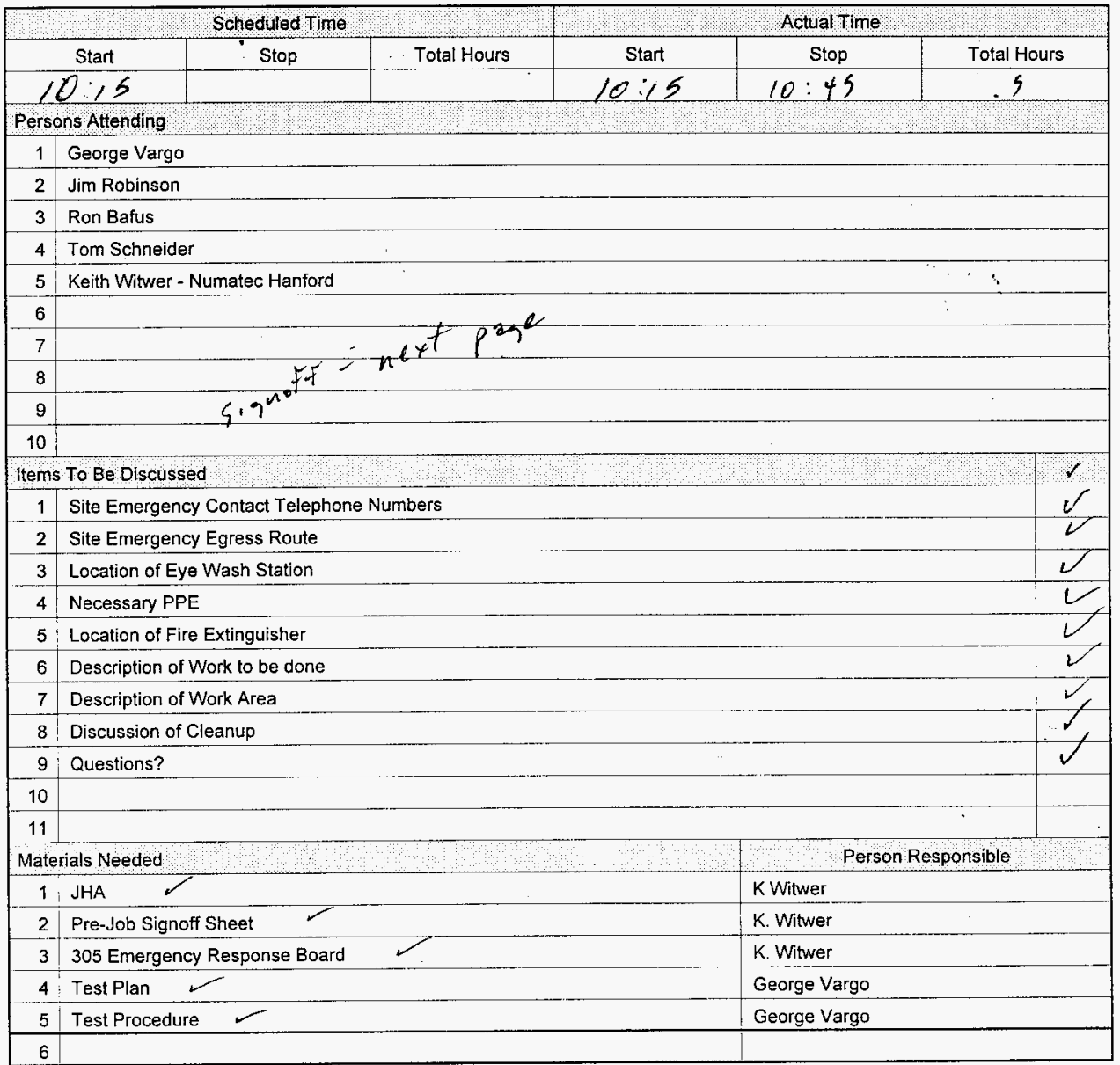


THIS PACE INTENTIONALLY LEFT BLANK 


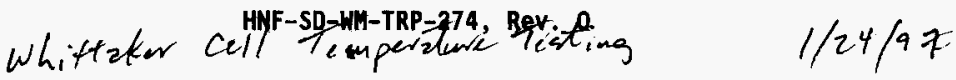

Pre-Job Safety Meeting Form

ATTENDANCE ROSTER

Page 2 of 2

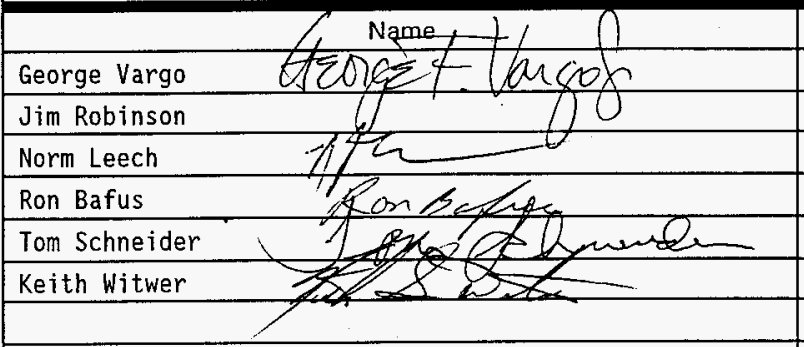

\begin{tabular}{|c|} 
Org. Code \\
O8EOO \\
\hline 80921 \\
\hline 8440 \\
80420 \\
80921
\end{tabular}

Payroll No.

94438

$960+5$

$6>945$

90483 82506 
THIS PAGE INTENTIONALLY LEFT BLANK 


\section{HNF-SD-WM-TRP-274, Rev, 0}

WESTINGHOUSE STANDARDS LABORATORY PHYSICAL AND ELECTRICAL REPORT

\begin{tabular}{|c|c|c|c|}
\hline \multirow{3}{*}{$\begin{array}{l}\text { CUSTODIAN/ADDRESS } \\
\text { JORDANN SR } \\
\text { L6-13 }\end{array}$} & \multicolumn{2}{|c|}{$\begin{array}{l}\text { STANDARDS CODE NUMBER } \\
752-67-11-004\end{array}$} & \\
\hline & \multirow[b]{2}{*}{ SERIAL NUMBER } & & \\
\hline & & PROPERTY NUMBER & $\begin{array}{l}\text { RECALL STATUS } \\
1 \text { ACTIVE }\end{array}$ \\
\hline DATA ACQUSN SYSTEM & $\frac{2511 \mathrm{AO} 02694}{\text { ROOM }}$ & $\frac{\text { WB9 } 96051}{\text { SERVICE DEPARTMENT }}$ & 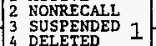 \\
\hline CONTROL UNIT & \begin{tabular}{l|l}
$N / A$ & 305 \\
\end{tabular} & & \begin{tabular}{|l}
5 \\
6
\end{tabular} \\
\hline
\end{tabular}

REW

MODIFY IOY 406439

ORGANIZATION CODE WORK ORDER \begin{tabular}{l|l}
$W 80000$ & N2224
\end{tabular}

\section{$\mathrm{K}$ WITWER 6-3019}

INSTRUMENT SPECIFICATIONS

ECALL CYCLE TOLERANCE HTSTORY

SEE TOLERANCE COLUMN STANDARD (S) USED IN CAIIBRATION TRACEABLE TO NATIONAL INSTTTUTE OF FANDARDS AND TECHNOLOGY
OR NATIONALIY RECOCNIZED STANDARDS
$4: 1$ RAT IO 4:1 RATIO Y W $\mathrm{N}$

$002-14-01-03627 / 25 / 97$

EXPIRATION DATE

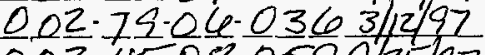

$002.45 .08 .0599725 / 97$

REMARKS

(WP-16)

PROCEDURE RUMBER WHC $-67-11-3497 A(12-82)$

360 IIII

DATE RECEIVED

970115 - $\begin{gathered}\text { CO ID } \\ 8\end{gathered} \mid$

TRAINING HOURS

CALIBRATION HOURS

REPAIR HOURS

OTHER HOURS

ENG/ADMIN HOURS

MATERTALS

TOTAL CHARGE =

( $\$ 150 \times$ SUM OF HOURS) + MATERIAI DATE CALIBRATED DATE DUE

$1 / 16 / 47 / 16 / 98$

AMBIENT TEMPERATURE $=24.4$
AS RECEIVED 12 IVI 2 OU 4 FAILED $4 *$

4

TOLERANCE
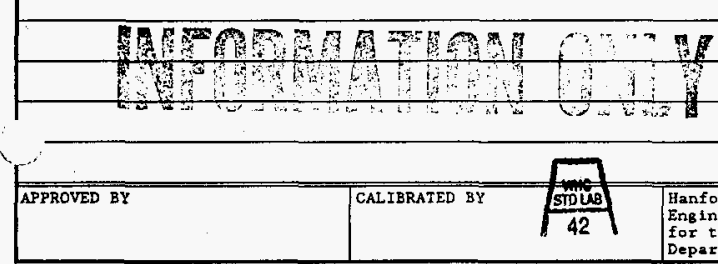

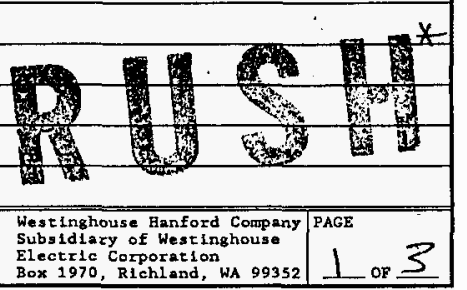
Engineering Contractor

for the United States

Depertment of Energy
Subsidiacy of Westinghouse

Box 1970, Rlchlend, WA 99352 
THIS PAGE INTENTIONALLY LEFT BLANK 
HNF-SD-HM-TRP-274, Rev. 0

PROCEDLRE KAME - 16

STANDARDS COOE NUMBER

REFERENCE NUMBER

WHC-67-11-3497A(12-82)

$752-67-11-004$

406439

DATA SHEET

\begin{tabular}{|c|c|c|c|c|}
\hline \multirow{2}{*}{$\begin{array}{l}\text { DMM RANGE } \\
\text { AND DISPLAY }\end{array}$} & \multirow{2}{*}{$\begin{array}{l}\text { STANDARD } \\
\text { READING }\end{array}$} & \multicolumn{2}{|c|}{ DMM READING } & \multirow{2}{*}{$\begin{array}{l}\text { ONE YEAR } \\
\text { TOLERANCE }\end{array}$} \\
\hline & & AS FOUND & FINAL & \\
\hline IV $5 \frac{1}{2}$ DIGIT & .100000 & .100001 & SAME & $\pm 18 \mu \mathrm{V}$ \\
\hline $1.0 \mathrm{~V}$ & 1.00000 & 1,00005 & & $\pm 160 \mu \mathrm{V}$ \\
\hline $10.0 \mathrm{~V}$ & 1.1111 & 1.11116 & & $\pm .3 \mathrm{mV}$ \\
\hline & 2.2222 & 2.2222 & & $\pm .4 \mathrm{mV}$ \\
\hline & 3.3333 & 3,3334 & & $\pm .6 \mathrm{mV}$ \\
\hline$\therefore$ & 4.4444 & 4.4445 & & $\pm .8 \mathrm{mV}$ \\
\hline & 5.5555 & 5.5557 & & $\pm .9 \mathrm{mV}$ \\
\hline & 6.6666 & 6,6668 & & $\pm 1.1 \mathrm{mV}$ \\
\hline & 7.7777 & 7.7779 & & $\pm 1.3 \mathrm{mV}$ \\
\hline & 8.8888 & 8.8891 & & $\pm 1.4 \mathrm{mV}$ \\
\hline & 9.9999 & 10.0002 & & $\pm 1.6 \mathrm{mV}$ \\
\hline & 10.0000 & 10.0003 & & $\pm 1.6 \mathrm{mV}$ \\
\hline $100.0 \mathrm{~V}$ & 50.000 & 50,002 & & $\pm 8.0 \mathrm{mV}$ \\
\hline & 100.000 & 100.003 & & $\pm 16.0 \mathrm{mV}$ \\
\hline & -100.000 & $-100,003$ & & $\pm 16.0 \mathrm{mV}$ \\
\hline$\therefore$ & -50.000 & $-50.00 z$ & & $\pm 8.0 \mathrm{mV}$ \\
\hline AUTO RANGE & 50.000 & 50,002 & & $\pm 8.0 \mathrm{mV}$ \\
\hline & 5.0000 & 5,0002 & & $\pm .8 \mathrm{mV}$ \\
\hline & .50000 & .50003 & & $\pm 80 \mu \mathrm{V}$ \\
\hline & .050000 & .049999 & & $\pm 10 \mu \mathrm{V}$ \\
\hline $10 \mathrm{~V} 4 \frac{1}{5}$ DIGIT & 9.000 & 9.000 & & $\pm 3.0 \mathrm{mV}$ \\
\hline IOV $3 \frac{1}{5}$ DIGIT & 9.00 & 9,00 &. & $\pm 20 \mathrm{mV}$ \\
\hline 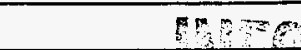 & $m-n=5$ & $\ldots$ & & \\
\hline $8 y^{3}$ & कीसी & 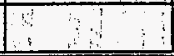 & 8 & \\
\hline
\end{tabular}


THIS PAGE INTENTIONALLY LEFT BLANK 
HNF-SD-WM-TRP-274, Rev. 0

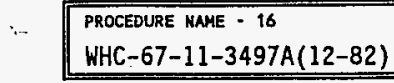

\begin{tabular}{|l|l|}
\hline $\begin{array}{l}\text { STANDAROS COOE NUMBER } \\
752-67-11-004\end{array}$ & $\begin{array}{l}\text { REFERENCE MUMBER } \\
406439\end{array}$ \\
\hline
\end{tabular}

\section{DATA SHEET}

\begin{tabular}{|c|c|c|c|c|}
\hline \multirow{2}{*}{$\begin{array}{l}\text { DMM RANGE } \\
\text { AND DISPLAY }\end{array}$} & \multirow{2}{*}{$\begin{array}{l}\text { STANDARD } \\
\text { READING }\end{array}$} & \multicolumn{2}{|c|}{ STANDARD INDICATION } & \multirow{2}{*}{$\begin{array}{l}\text { ONE YEAR } \\
\text { TOLERANCE }\end{array}$} \\
\hline & & AS FOUND & FINAL & \\
\hline \multicolumn{5}{|l|}{ CURRENT OUT } \\
\hline $1 \mathrm{ma}$ & & 1,000032 & SAME & \pm 320 ua \\
\hline 100 ua & & 49.4962 & & \pm .032 ua \\
\hline 10ua & & 10.0025 & & \pm .0032 ua \\
\hline CJ comp (READON) & $2.5 \vee 0,25^{\circ} \mathrm{C} q$ & $2.85_{A T 29}$ & & $+1{ }^{\circ} \mathrm{C}$ or $.1 \mathrm{Vdl}$ \\
\hline$(4,19)$ & $100 \mathrm{mV} /{ }^{\circ} \mathrm{C}$ & & $\downarrow$ & \\
\hline & & & & \\
\hline . & & & & \\
\hline & & & & \\
\hline & & & & \\
\hline & & & & \\
\hline & & & & \\
\hline & & & & \\
\hline & & & & \\
\hline : & & & & \\
\hline $7=-\cdots$ & & & & \\
\hline & & & & \\
\hline & & & & \\
\hline & & & & \\
\hline & & & & \\
\hline & & & & \\
\hline$P=5$ & W, & $\sin \theta$ & E & \\
\hline . & की & $10^{3}$ & 政量 & \\
\hline
\end{tabular}

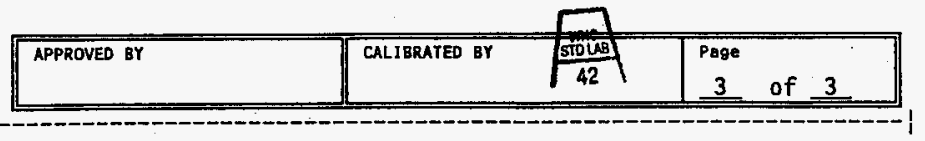


THIS FIGE INTENTIONALLY LEFT BLANK 
HNF-SD-HN-TRP-274, R2v. O,

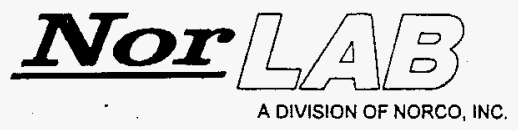

\section{Calibration Gases \& Equipment}

\section{CERTIFICATE OF ANALYSIS}

Norco

Date: March 4, 1996

Kennewick Warehouse

102 E. Columbia Dr.

Kennewick, WA 99336-0000

Cylinder Number: TWC041277

PO Number: None.

Norco Order Number: $720091-00$

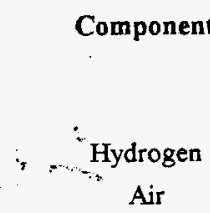

Air
Reported Concentration

$0.999 \%$

Balance .
Analysis $+/-2 \%$

Approved:

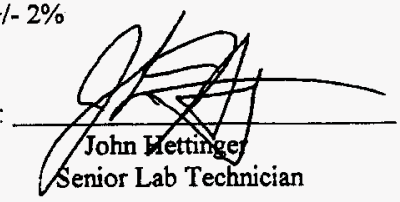

Lot \#: $6-062-100$

\section{Requested Concentration}

$1 \%$

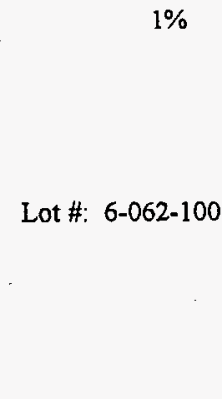


THIS PAGE INTENTIONALLY

LEFT BLANK 
HAF-SD-WH-TRP-274, Rev. 0

\begin{tabular}{|c|c|c|}
\hline $\begin{array}{l}\text { PROLEDURE MAKE } 216 \\
\text { HHC-5-RMT-305ICA REV.3 30PSIA }\end{array}$ & $\begin{array}{l}\text { STMLAKOS COE MABER } \\
355-80-02-056\end{array}$ & $\begin{array}{l}\text { REFRANE MUER } \\
400762\end{array}$ \\
\hline
\end{tabular}

\section{DATA SHEET}

\begin{tabular}{|c|c|c|c|c|c|}
\hline \multicolumn{2}{|c|}{ TEST POINTS } & \multicolumn{2}{|c|}{ AS FOUND } & FINAL & TOLERANCE \\
\hline MA & PSIA & MA - & PSIA & MA PSIA & MA PSIA \\
\hline 4 & 0 & 3.556 & .0035 & SAme & $7-.032 \%-.06$ \\
\hline 8 & 7.5 & 8.000 & 2.511 & & 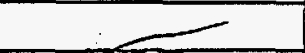 \\
\hline 12 & 15.0 & 12001 & 15.01 & & \\
\hline 16 & 22.5 & 16001 & 22.51 & ) & \\
\hline 20 & 30.0 & 20.004 & 30.02 & $\checkmark$ & 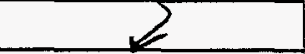 \\
\hline \multicolumn{6}{|c|}{ : } \\
\hline & & & & . & \\
\hline & & & & & \\
\hline & & & & & \\
\hline & & & & & . \\
\hline & & & & & \\
\hline & & & & & \\
\hline & & & & & \\
\hline & & & & & \\
\hline & & & & & \\
\hline & & & & & \\
\hline & & & & & \\
\hline & & & & & \\
\hline & & & & & \\
\hline$=$ & & & & & \\
\hline & & & & & \\
\hline & & & & & \\
\hline & & & & & \\
\hline & & . & . & & \\
\hline
\end{tabular}


THIS PFECIE INTENTIONALLY LEFT BLANK 
WTF-SD-WM-TRP-274, Rev. 0

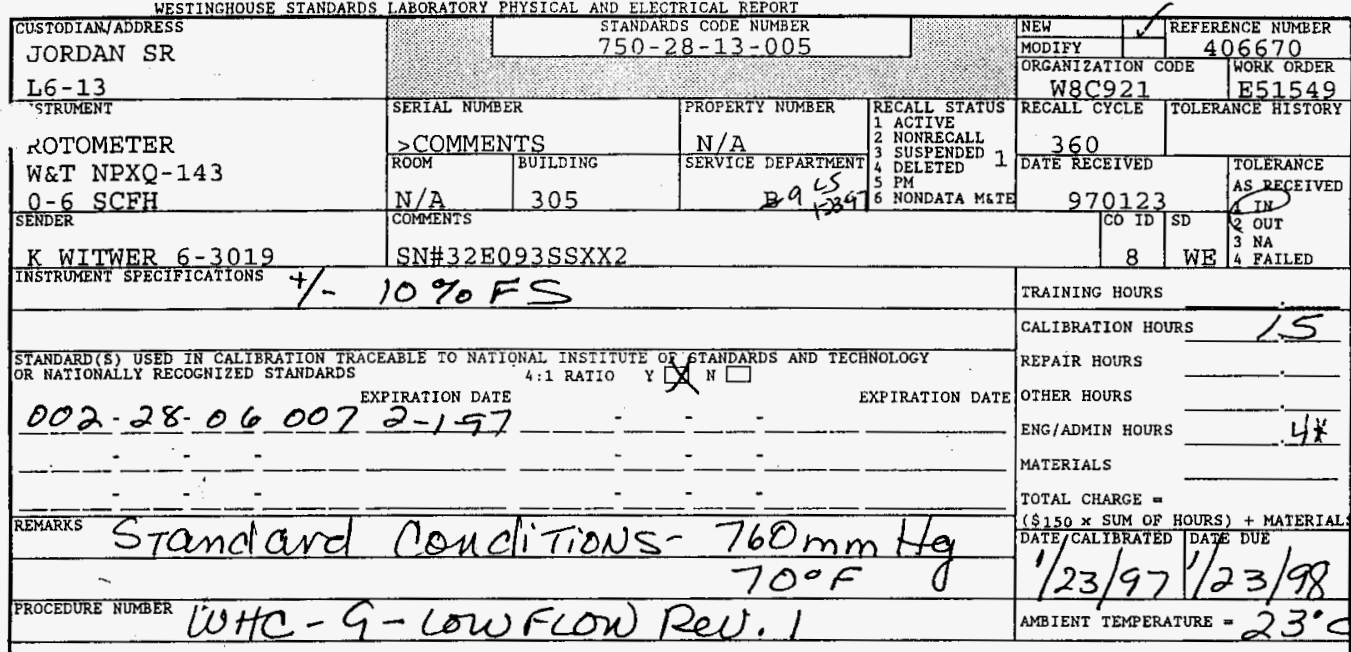

TEST Points ASFQOND FINAL $\omega=T \quad$ Stanalard

1. SCFH

2.

,

3.

4.

1.17 SCFH SamE

$2 . ? 611$

3.34

4.22

5.33

6.

$5.76 \%$

Tor.

+0.6SCFH

\begin{tabular}{|}
\hline \\
\hline \\
\hline \\
\hline \\
\hline
\end{tabular}

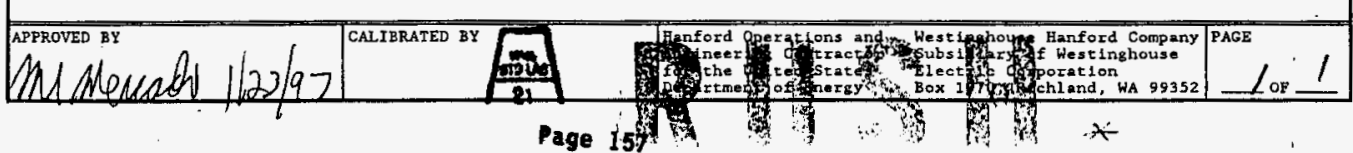


TH:O AGE INTENTIONALLY LEFT BLANK 
WF-SD-KM-TRP-274, Rev. 0

WESTINGHOUSE STANDARDS LABORATORY PHYSICAL AND ELECTRICAL REPORT

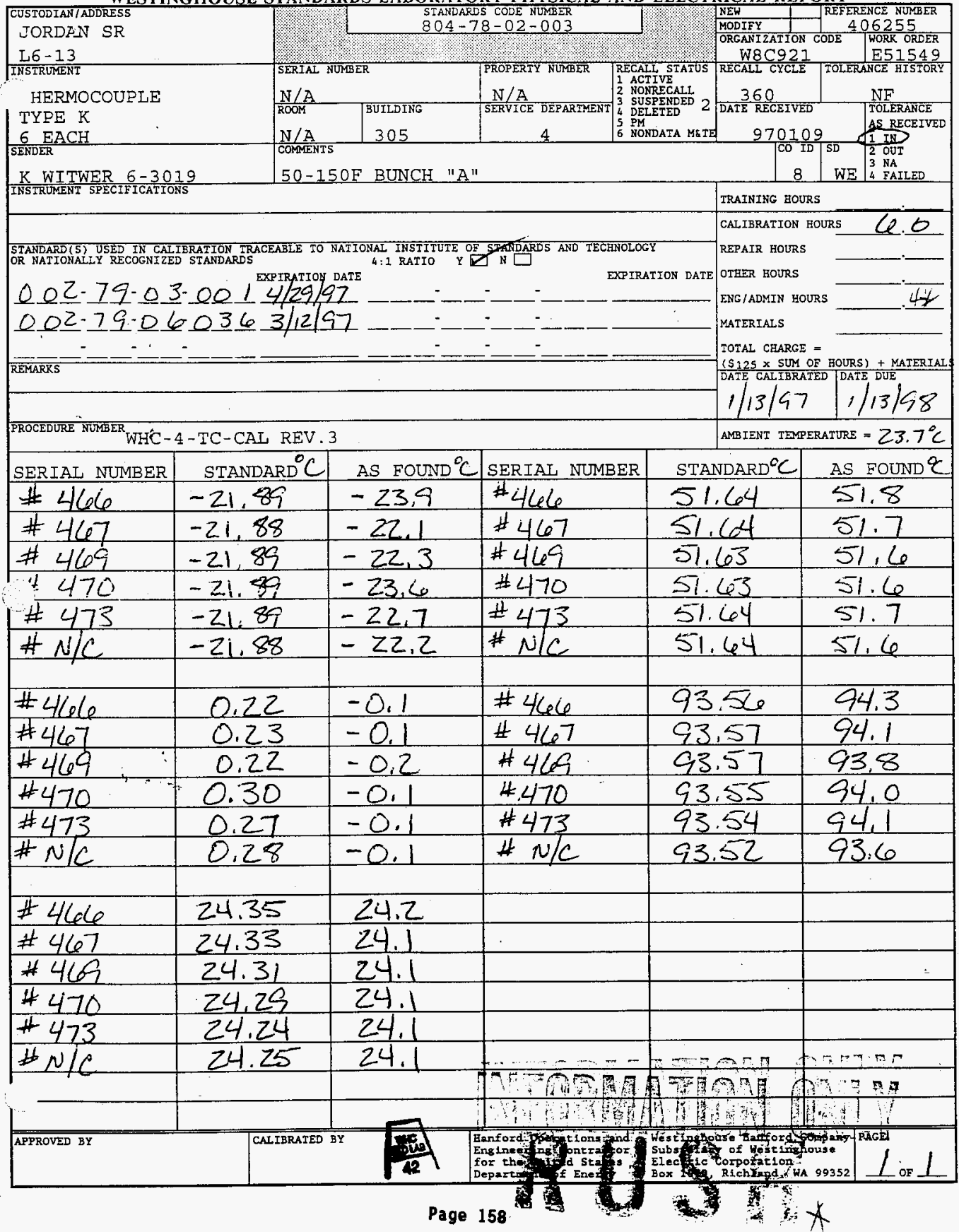


THIS PAGE INTENTIONALLY LEFT BLANK 


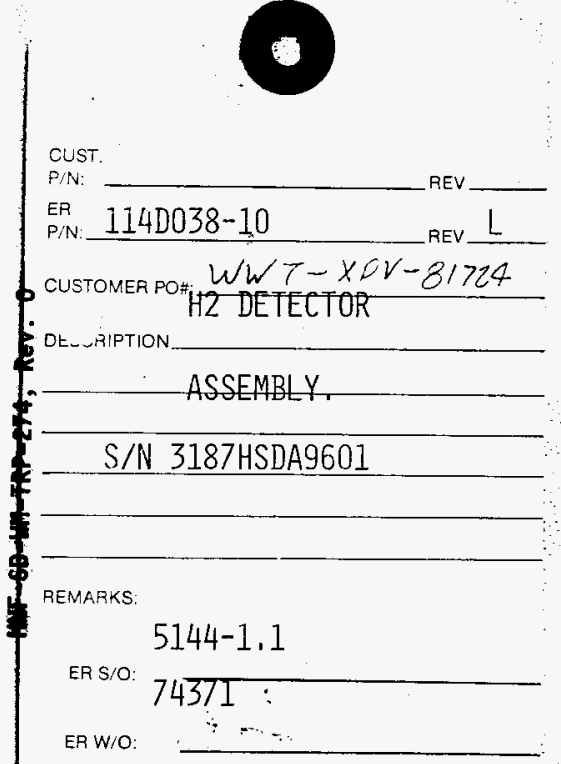

REMARKS:

$E-2180$

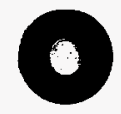

CUST.

PIN: $\longrightarrow$ REV

ER

PIN $114 D 038-10$

CLINOMER PO: WW7-XDV-81724

DESCRIPTION_H2 DETECTOR ASSEMBLY,

S/N 3209HSDÄ960I

JAN 261996

REMARKS

ER S/O: $\quad 5144-1.1$

ER W/O: 74422

REMARKS:

$E-2180$ 
THIS PAGE INTENTIONALLY LEFT BLANK 


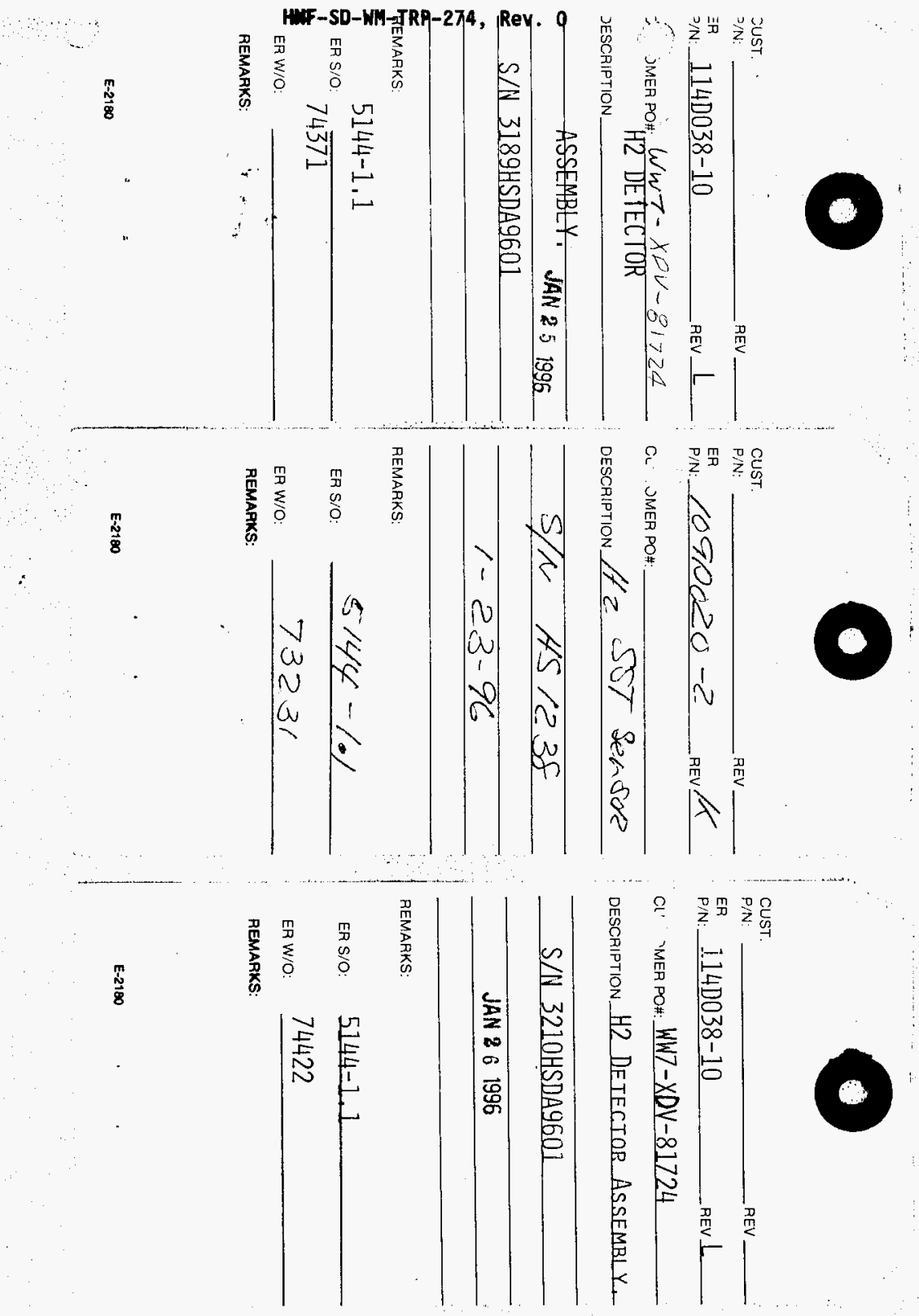


THIS FAGE INTENTIONALLY LEFT BLANK 
- Provides Both Galvanically Isolated and intrinsically Saíe Connections for one Thermocouple or Pulse Input Transducer

- Measurement Ranges $\pm 100 \mathrm{mV}, \pm 1 \mathrm{~V}, \pm 10 \mathrm{~V}$

- Accepts Frequency Inputs up to $2.5 \mathrm{kHz}$

- Provides Open-Circuit Monitoring

- LED Indication for Unit Supply and Open-Circuit Condition

- Meets Latest Electromagnetic Compatability Standards

- Reverse Polarity Protection

- $35 \mathrm{~mm}$ DiN Rail or Surface Mount

- Approvals to Worldwióe Standaros

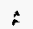

\section{Operational Description}

The Type $9323 \mathrm{mV}$ isolating Repeater provides both galvanically isolated and intrinsically sate connections for one thermocouple or pu'se input transducer instailedin a hazardous location, It transmits DC or AC voltage signals $1: 1$ to the cutput.

The switched mode power section 1 generates the galvanically isolated supply voltages for the intrinsically safe input circuit and the nonintrinsicaily sate output circuit. A green LED indicates when power is on and the internat fuse is intact.

The voltage applied to the IS input 2 is transmitted with galvanic isolation via signal matching circuit 3 and DC/DC converter 4 to output amplifier 5 : The voltage polarity is maintained.

With units having open circuit monitoring for the voltage generating transducers, the current generator 6 feeds a constant current through the transducers connected to the intrinsically safe input. When there is an open circuit, the red LED 7 comes on. Output amplifier 5 reacts to the open circuit condition with an excessive positive output signal, which can be evaluated in the control system as a fault.
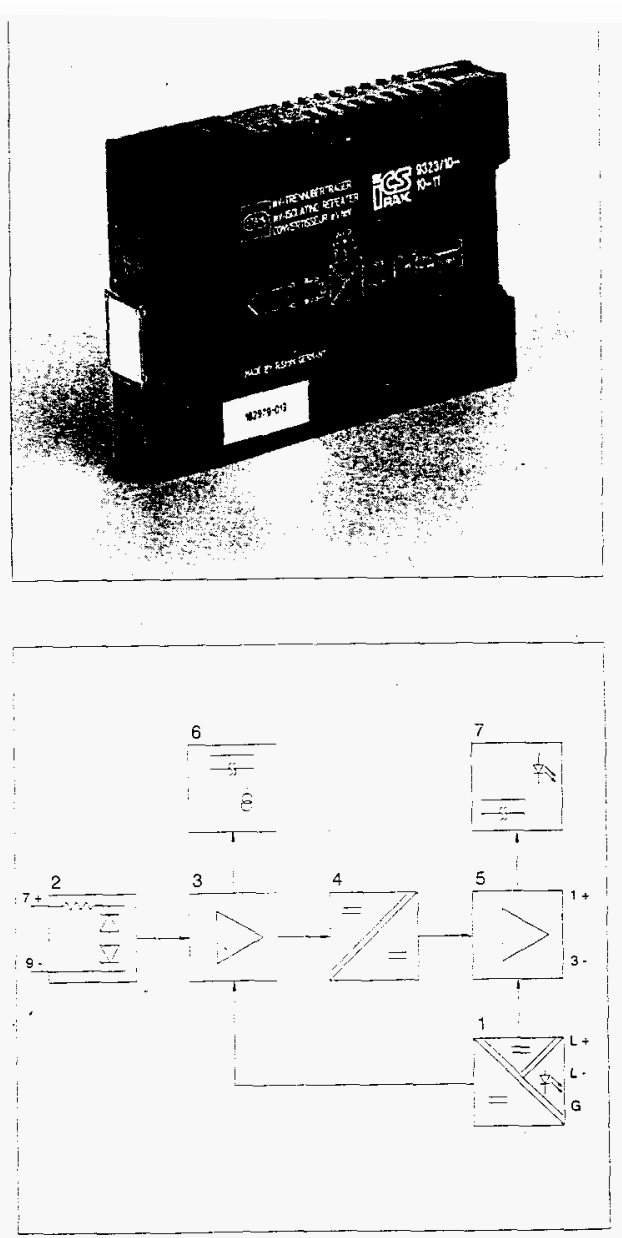

Ordering Information

$\begin{array}{ll}9323 / 10-10-10 & \pm 100 \mathrm{mV} \text { input signal } \\ 9323 / 10-10-11 & \pm 100 \mathrm{mV} \text { input signal with open-circuit monitoring } \\ 9323 / 10-20-10 & \pm 1 \mathrm{~V} \text { input signal } \\ 9323 / 10-30-10 & \pm 10 \mathrm{~V} \text { voliage input signal or }\end{array}$




\section{THIS FACE INTENTIONALLY LEFT BLANK}


THIS PAGE INTENTIONALLY LEFT BLANK 
WWF-SD-MI-TRP-274, Rev. 0

REV

$90020-2$ REV /

PO\#:

on 1 z SOT Sensor

$$
\begin{array}{|l}
\frac{14 S / 238}{1-23-96} \\
\frac{5144-1 \%}{73231} \\
\hline
\end{array}
$$

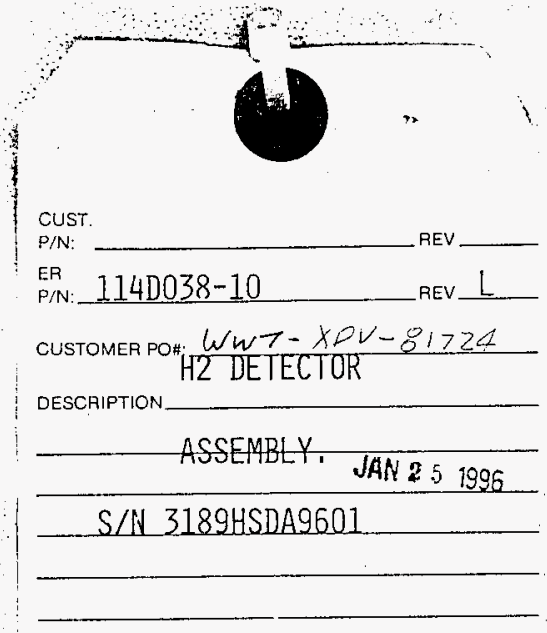

REMARKS:

5144-1.1

ER SO: $74 \overline{371}$

ER WTO:

REMARKS:

$E-2100$

Page 163 
THIS PAGE INTENTIONALLY LEFT BLANK 
MF-SD-WH-ThP-274, Rev. O

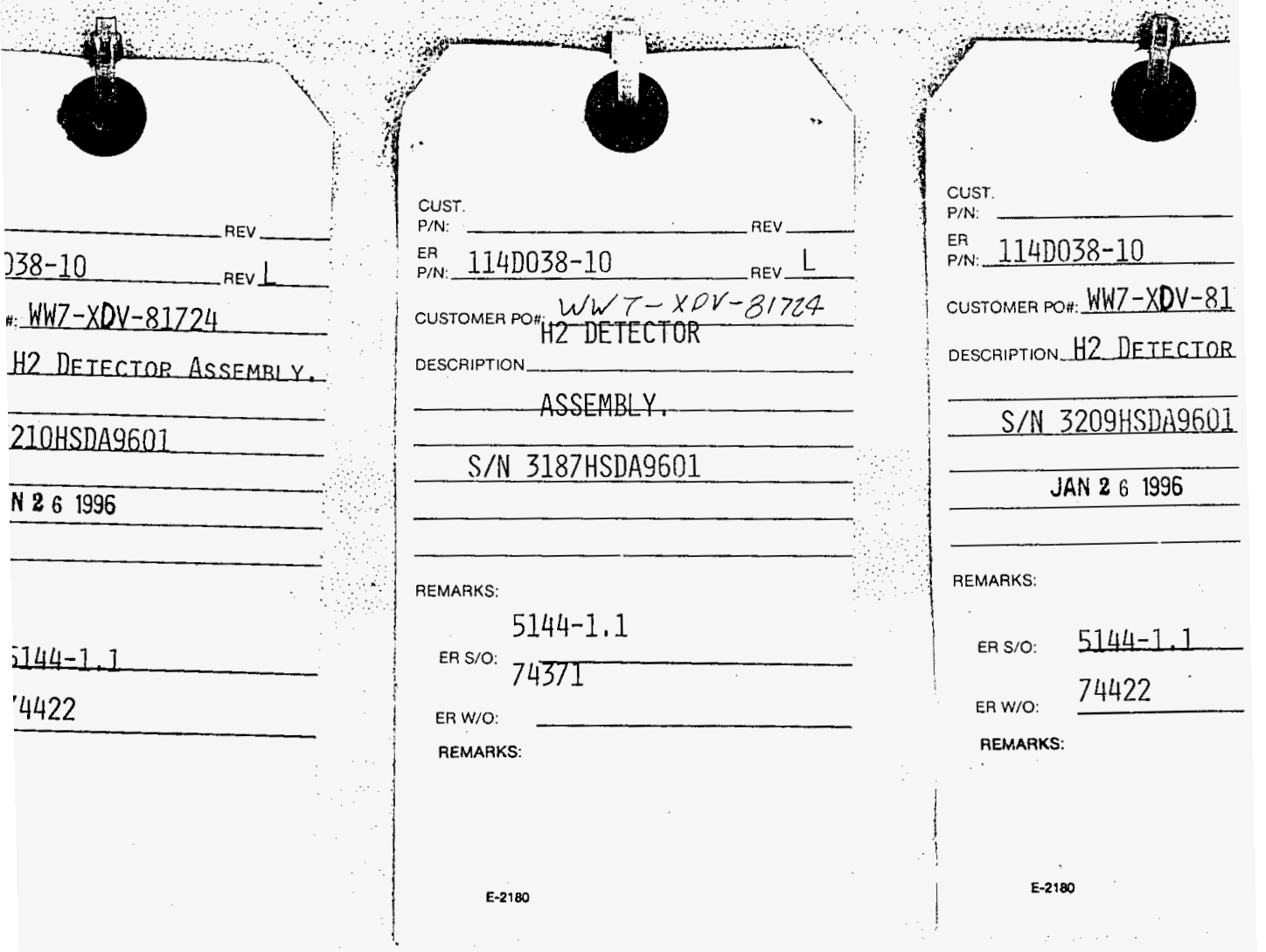


THIS PAGE INTENTIONALLY LEFT BLANK 

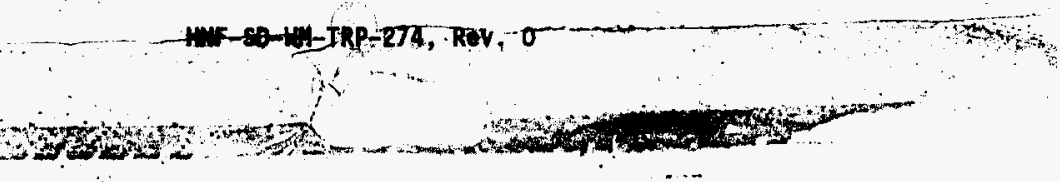

(9) Scott Specialty Gases

WESTINGHOLSE HANFORI

CAS Reg. Component No. L : onen:
CERTIFICATE OF ANALYSIS PO No WGKXYU409472

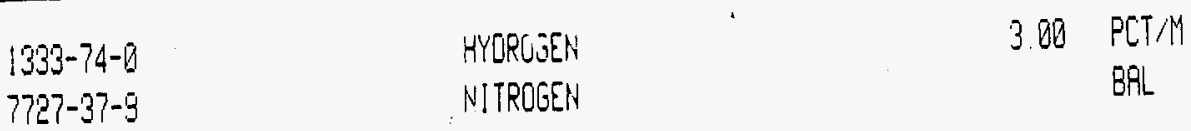

sortified Hrialysis

Project No $99-21513$

Cylinder No. 1C3409 llem No.09022342 $4 \mathrm{~A}$

Grade CERTIFIEU MAGTER GRS

Reorder/Service Contact.

(10)659-0162 FREMONT

[A 9459 
THIS F.CE INTENTIONALLY LEFT BLANK 


\section{ANALYSIS OF TEMPERATURE EFFECTS ON WHITTAKER CELL CALIBRATION}

Assumptions

1. This analysis is based on the actual values from Whittaker Cells \#2 and \#4 for zero gas and $10,000 \mathrm{ppm} \mathrm{H}_{2}$ gas.

2. The input of the Newport meter on the FGI will be scaled for zero gas and $10,000 \mathrm{ppm}_{2}$ after 15 minutes.

3. The output of the Newport meter on the FGI will be scaled for:

$$
\begin{aligned}
4 \mathrm{~mA} & =0 \mathrm{ppm} \mathrm{H}_{2} \\
20 \mathrm{~mA} & =10,000 \mathrm{ppm} \mathrm{H} \mathrm{H}_{2}
\end{aligned}
$$

Scenario \#1

Whittaker Ce11 \#2 calibrated at $70^{\circ} \mathrm{F}$.

After scaling the Newport the following values would apply at $70^{\circ} \mathrm{F}$ :

\begin{tabular}{|c|c|c|c|c||}
\hline $\begin{array}{c}\text { Gas Concentration } \\
\left.\text { (ppm } H_{2}\right)\end{array}$ & $\begin{array}{c}\text { Whittaker } \\
\text { Output (mV) }\end{array}$ & $\begin{array}{c}\text { Newport } \\
\text { Display (ppm) }\end{array}$ & $\begin{array}{c}\text { Newport } \\
\text { Output (mA) }\end{array}$ & $\begin{array}{c}\text { PLC Display } \\
\text { (ppm) }\end{array}$ \\
\hline 0 & 0.239 & 0 & 4.00 & 0 \\
\hline 10,000 & 1.760 & 10,000 & 20.00 & 10,000 \\
\hline
\end{tabular}

The following straight line equations may be used to calculate the Newport and PLC responses for other Whittaker Output values given the scaling of the Newport provided above.

Newport Display $=6575 *$ (Whittaker Output) -1571

Newport Output $=10.52$ * (Whittaker Output $)+1.49$

PLC Disp1ay $=6575 *$ (Whittaker Output $)-1571$

The actual gas concentration at which the FGI will trip it's 5,000 ppm alarm can be interpolated from the Newport Display values corresponding to 0 and $10,000 \mathrm{ppm} \mathrm{H}_{2}$ at the given temperature. 
THIS PAGE INTENTIONALLY LEFT BLANK 
The responses of the FGI system at varying temperatures are shown below:

\begin{tabular}{|c|c|c|c|c|c|c|}
\hline Temp. & $\begin{array}{l}\text { Gas cone. } \\
\text { (ppon He) }\end{array}$ & $\begin{array}{l}\text { Uhittaker, } \\
\text { output (mV) }\end{array}$ & $\begin{array}{l}\text { Newport } \\
\text { Display (ppm) }\end{array}$ & $\begin{array}{l}\text { Newport: } \\
\text { output (mA) }\end{array}$ & $\begin{array}{l}\text { PLC o isplay } \\
\text { (ppon) }\end{array}$ & $\begin{array}{l}\text { Actual Gas cone, at } \\
\text { 5,000 ppia alarm trip. }\end{array}$ \\
\hline \multirow[t]{2}{*}{60} & 0 & 0.312 & 480 & 4.77 & 480 & \multirow[t]{2}{*}{4,479} \\
\hline & 10,000 & 1.847 & 10,572 & $20^{*}$ & $10,000^{*}$ & \\
\hline \multirow[t]{2}{*}{70} & 0 & 0.239 & 0 & 4.00 & 0 & \multirow[t]{2}{*}{5,000} \\
\hline & 10,000 & 1.760 & 10,000 & 20.00 & 10,000 & \\
\hline \multirow[t]{2}{*}{80} & 0 & 0.190 & -322 & $4^{*}$ & $0^{*}$ & \multirow[t]{2}{*}{5,533} \\
\hline & 10,000 & 1.653 & 9,297 & 18.87 & 9,297 & \\
\hline \multirow[t]{2}{*}{100} & 0 & 0.136 & -677 & $4^{*}$ & $0^{*}$ & \multirow[t]{2}{*}{6,000} \\
\hline & 10,000 & 1.575 & 8784 & 18.05 & 8,784 & \\
\hline
\end{tabular}

Conclusion: If the Whittaker were calibrated at $70^{\circ} \mathrm{F}$, it is acceptable to operate the RMCS truck at a Whittaker temperature between $60^{\circ} \mathrm{F}$ and $70^{\circ} \mathrm{F}$.

Scenario \#2

Whittaker Ce11 \#2 calibrated at $80^{\circ} \mathrm{F}$.

After scaling the Newport the following values would apply at $80^{\circ} \mathrm{F}$ :

\begin{tabular}{|c|c|c|c|c|}
\hline $\begin{array}{c}\text { Gas Concentration } \\
\text { (ppm } H_{2} \text { ) }\end{array}$ & $\begin{array}{c}\text { Whittaker } \\
\text { output (mV) }\end{array}$ & $\begin{array}{r}\text { Newport } \\
\text { Display (ppm) }\end{array}$ & $\begin{array}{r}\text { Newport } \\
\text { Output (mA) }\end{array}$ & $\begin{array}{r}\text { PLC Display } \\
\text { (ppm) }\end{array}$ \\
\hline 0 & 0.190 & 0 & 4.00 & 0 \\
\hline 10,000 & 1.653 & 10,000 & 20.00 & 10,000 \\
\hline
\end{tabular}

The following straight 1 ine equations may be used to calculate the Newport and PLC responses for other Whittaker Output values given the scaling of the Newport provided above.

Newport Display $=6835$ * (Whittaker Output) -1299

Newport Output $=10.94 *$ (Whittaker Output) +1.92

PLC Display $=6835$ * (Whittaker Output) -1299

The actual gas concentration at which the FGI wi11 trip it's 5,000 ppm alarm can be interpolated from the Newport Display values corresponding to 0 and $10,000 \mathrm{ppm} \mathrm{H}_{2}$ at the given temperature. 
THIS PAGE INTENTIONALLY LEFT BLANK 
The responses of the FGI system at varying temperatures are shown below:

\begin{tabular}{|c|c|c|c|c|c|c|}
\hline Temp. & $\begin{array}{l}\text { Gas Conc. } \\
\text { (ppen H }\end{array}$ & $\begin{array}{l}\text { Whitraker } \\
\text { output (in) }\end{array}$ & $\begin{array}{l}\text { Newport } \\
\text { Display (ppm) } \\
\end{array}$ & $\begin{array}{l}\text { Newport } \\
\text { cutput (mA) } \\
\end{array}$ & $\begin{array}{c}P L C \text { ol splay } \\
\text { (pPR) }\end{array}$ & $\begin{array}{l}\text { Actual Gas conc at } \\
5,000 \text { ppm alarm trip. }\end{array}$ \\
\hline \multirow[t]{2}{*}{60} & 0 & 0.312 & 834 & 5.33 & 834 & \multirow[t]{2}{*}{3,971} \\
\hline & 10,000 & 1.847 & 11,326 & $20^{*}$ & $10,000^{*}$ & \\
\hline \multirow[t]{2}{*}{70} & 0 & 0.239 & 335 & 4.54 & 335 & \multirow[t]{2}{*}{4,487} \\
\hline & 10,000 & 1.760 & 10,731 & $20^{*}$ & $10,000^{*}$ & \\
\hline \multirow[t]{2}{*}{80} & 0 & 0.190 & 0 & 4.00 & 0 & \multirow[t]{2}{*}{5,000} \\
\hline & 10,000 & 1.653 & 10,000 & 20.00 & 10,000 & \\
\hline \multirow[t]{2}{*}{100} & 0 & 0.136 & -369 & $4^{*}$ & $0^{*}$ & \multirow[t]{2}{*}{5,459} \\
\hline & 10,000 & 1.575 & 9467 & 19.15 & 9,467 & \\
\hline
\end{tabular}

Conclusion: If the Whittaker were calibrated at $80^{\circ} \mathrm{F}$, it is acceptable to operate the RMCS truck at a Whittaker temperature between $60^{\circ} \mathrm{F}$ and $80^{\circ} \mathrm{F}$, however it is likely that the $S A D-0351 \mathrm{imit}$ of $\leq 1,000 \mathrm{ppm}$ prior to sampling will not be achievable below $70^{\circ} \mathrm{F}$.

Scenario \#3

Whittaker Cell \#2 calibrated at $100^{\circ} \mathrm{F}$.

After scaling the Newport the following values would apply at $100^{\circ} \mathrm{F}$ :

\begin{tabular}{|c|c|c|c|c|}
\hline $\begin{array}{c}\text { Gas Concentration } \\
\text { (ppm H) }\end{array}$ & $\begin{array}{c}\text { Whittaker } \\
\text { Output (mV) }\end{array}$ & $\begin{array}{r}\text { Newport } \\
\text { Display (ppm) }\end{array}$ & $\begin{array}{r}\text { Newport } \\
\text { Output (mA) }\end{array}$ & $\begin{array}{c}\text { PLC Display } \\
\text { (ppm) }\end{array}$ \\
\hline 0 & 0.136 & 0 & 4.00 & 0 \\
\hline 10,000 & 1.575 & 10,000 & 20.00 & 10,000 \\
\hline
\end{tabular}

The following straight line equations may be used to calculate the Newport and PLC responses for other Whittaker Output values given the scaling of the Newport provided above.

Newport Display $=6949 *$ (Whittaker Output) -945

Newport Output $=11.12 *$ (Whittaker Output $)+2.49$

PLC Display $=6949 *$ (Whittaker Output) -945

The actual gas concentration at which the FGI will trip it's 5,000 ppm alarm can be interpolated from the Newport Display values corresponding to 0 and $10,000 \mathrm{ppm} \mathrm{H}_{2}$ at the given temperature. 
THIS PAGE INTENTIONALLY LEFT BLANK 
The responses of the FGI system at varying temperatures are shown below:

\begin{tabular}{|c|c|c|c|c|c|c|}
\hline Temp. & $\begin{array}{l}\text { Gas conc, } \\
\text { (ppm H, }\end{array}$ & $\begin{array}{l}\text { Whittaker } \\
\text { outsput (mV) }\end{array}$ & $\begin{array}{l}\text { Newport } \\
\text { Display (ppm) }\end{array}$ & $\begin{array}{l}\text { Newport } \\
\text { Output (mA) }\end{array}$ & $\begin{array}{l}\text { PLC Display } \\
\text { (pom) }\end{array}$ & $\begin{array}{l}\text { Actual Gas conc, at } \\
5,000 \text { ppi alarm trip. }\end{array}$ \\
\hline \multirow[t]{2}{*}{60} & 0 & 0.312 & 1223 & 5.96 & 1223 & \multirow[t]{2}{*}{3,541} \\
\hline & 10,000 & 1.847 & 11,890 & $20^{*}$ & $10,000^{*}$ & \\
\hline \multirow[t]{2}{*}{70} & 0 & 0.239 & 716 & 5.15 & 716 & \multirow[t]{2}{*}{4,053} \\
\hline & 10,000 & 1.760 & 11,286 & $20^{*}$ & $10,000^{*}$ & \\
\hline \multirow[t]{2}{*}{80} & 0 & 0.190 & 375 & 4.60 & 375 & \multirow[t]{2}{*}{4,549} \\
\hline & 10,000 & 1.653 & 10,542 & $20^{*}$ & $10,000^{*}$ & \\
\hline \multirow[t]{2}{*}{100} & 0 & 0.136 & 0 & 4.00 & 0 & \multirow[t]{2}{*}{5,000} \\
\hline & 10,000 & 1.575 & 10,000 & 20.00 & 10,000 & \\
\hline
\end{tabular}

Conclusion: If the Whittaker were calibrated at $100^{\circ} \mathrm{F}$, it is acceptable to operate the RMCS truck at a Whittaker temperature between $60^{\circ} \mathrm{F}$ and $100^{\circ} \mathrm{F}$, however it is likely that the SAD-035 limit of $\leq 1,000 \mathrm{ppm}$ prior to sampling will not be achievable below $80^{\circ} \mathrm{F}$.

Scenario \#4

Whittaker Cell \#4 calibrated at $70^{\circ} \mathrm{F}$.

After scaling the Newport the following values would apply at $70^{\circ} \mathrm{F}$ :

\begin{tabular}{|c|c|c|c|c|}
\hline $\begin{array}{c}\text { Gas Concentration } \\
\text { (ppm H) }\end{array}$ & $\begin{array}{r}\text { Whittaker } \\
\text { Output (mV) }\end{array}$ & $\begin{array}{r}\text { Newport } \\
\text { Display (ppm) }\end{array}$ & $\begin{array}{r}\text { Newport } \\
\text { Output (mA) }\end{array}$ & $\begin{array}{c}\text { PLC Bisplay } \\
\text { (ppm) }\end{array}$ \\
\hline 0 & 0.242 & 0 & 4.00 & 0 \\
\hline 10,000 & 1.834 & 10,000 & 20.00 & 10,000 \\
\hline
\end{tabular}

The following straight line equations may be used to calculate the Newport and PLC responses for other Whittaker Output values given the scaling of the Newport provided above.

Newport Display $=6281 *$ (Whittaker Output) -1520

Newport Output $=10.05 *$ (Whittaker Output $)+1.57$

PLC Display $=6281$ * (Whittaker Output $)-1520$

The actual gas concentration at which the FGI will trip it's 5,000 ppm alarm can be interpolated from the Newport Display values corresponding to 0 and $10,000 \mathrm{ppm}_{2}$ at the given temperature. 
THIS PAGE INTENTIONALLY LEFT BLANK 
The responses of the FGI system at varying temperatures are shown below:

\begin{tabular}{|c|c|c|c|c|c|c|}
\hline Temp, & $\begin{array}{l}\text { Gas conc, } \\
\text { (opm H, }\end{array}$ & $\begin{array}{l}\text { Whitraker, } \\
\text { output (mv) }\end{array}$ & $\begin{array}{l}\text { Neuport } \\
\text { Display (ppm) }\end{array}$ & $\begin{array}{l}\text { Newport } \\
\text { output (ma) }\end{array}$ & $\begin{array}{l}\text { Plic oisplay } \\
\text { (rppr) }\end{array}$ & $\begin{array}{l}\text { Actual Gas conc, at } \\
\text { 5, 000 eppolarm trip. }\end{array}$ \\
\hline \multirow[t]{2}{*}{60} & 0 & 0.312 & 440 & 4.70 & 440 & \multirow[t]{2}{*}{4,405} \\
\hline & 10,000 & 1.960 & 10,791 & $20^{*}$ & $10,000^{*}$ & \\
\hline \multirow[t]{2}{*}{70} & 0 & 0.242 & 0 & 4.00 & 0 & \multirow[t]{2}{*}{5,000} \\
\hline & 10,000 & 1.834 & 10,000 & 20.00 & 10,000 & \\
\hline \multirow[t]{2}{*}{80} & 0 & 0.192 & -314 & $4^{*}$ & $0^{*}$ & \multirow[t]{2}{*}{5,685} \\
\hline & 10,000 & 1.680 & 9,033 & 18.45 & 9,033 & \\
\hline \multirow[t]{2}{*}{100} & 0 & 0.164 & -490 & $4^{*}$ & $0^{*}$ & \multirow[t]{2}{*}{5,870} \\
\hline & 10,000 & 1.653 & 8863 & 18.18 & 8,863 & \\
\hline
\end{tabular}

Conclusion: If the Whittaker were calibrated at $70^{\circ} \mathrm{F}$, it is acceptable to operate the RMCS truck at a Whittaker temperature between $60^{\circ} \mathrm{F}$ and $70^{\circ} \mathrm{F}$.

Scenario \#5

Whittaker Cell \#4 calibrated at $80^{\circ} \mathrm{F}$.

After scaling the Newport the following values would apply at $80^{\circ} \mathrm{F}$ :

\begin{tabular}{|c|c|c|c|c|}
\hline $\begin{array}{c}\text { Gas Concentration } \\
\text { (ppm H, }\end{array}$ & $\begin{array}{r}\text { Whittaker } \\
\text { Output (mV) }\end{array}$ & $\begin{array}{r}\text { Newport } \\
\text { Display (ppm) }\end{array}$ & $\begin{array}{r}\text { Newport } \\
\text { Output (mA) }\end{array}$ & $\begin{array}{c}\text { PLC Display } \\
\text { (ppm) }\end{array}$ \\
\hline 0 & 0.192 & 0 & 4.00 & 0 \\
\hline 10,000 & 1.680 & 10,000 & 20.00 & 10,000 \\
\hline
\end{tabular}

The following straight line equations may be used to calculate the Newport and PLC responses for other Whittaker Output values given the scaling of the Newport provided above.

Newport Display $=6720 *$ (Whittaker Output) -1290

Newport Output $=10.75 *($ Whittaker Output $)+1.94$

PLC Display $=6720$ * (Whittaker Output) -1290

The actual gas concentration at which the FGI will trip it's 5,000 ppm alarm can be interpolated from the Newport Display values corresponding to 0 and $10,000 \mathrm{ppm} \mathrm{H}_{2}$ at the given temperature. 
THIS PAGE INTENTIONALLY LEFT BLANK 
HNF-SD-WM-TRP-274, REV 0

The responses of the FGI system at varying temperatures are shown below:

\begin{tabular}{|c|c|c|c|c|c|c|}
\hline temp. & $\begin{array}{l}\text { Gas conce. } \\
\text { (ppon H, }\end{array}$ & $\begin{array}{l}\text { Whittaker } \\
\text { output (mv) }\end{array}$ & $\begin{array}{l}\text { Newport } \\
\text { Display (ppen) }\end{array}$ & $\begin{array}{l}\text { Newport } \\
\text { output (mA) } \\
\end{array}$ & $\begin{array}{c}P L C \text { oisplay } \\
\text { (ppm) }\end{array}$ & $\begin{array}{l}\text { Actual Gas cone, at } \\
\text { 5, 000 ppi alarm trip. }\end{array}$ \\
\hline \multirow[t]{2}{*}{60} & 0 & 0.312 & 806 & 5.29 & 806 & \multirow[t]{2}{*}{3,787} \\
\hline & 10,000 & 1.960 & 11,882 & $20^{\star}$ & $10,000^{*}$ & \\
\hline \multirow[t]{2}{*}{70} & 0 & 0.242 & 336 & 4.54 & 336 & \multirow[t]{2}{*}{4,359} \\
\hline & 10,000 & 1.834 & 11,035 & $20^{*}$ & $10,000^{*}$ & \\
\hline \multirow[t]{2}{*}{80} & 0 & 0.192 & 0 & 4.00 & 0 & \multirow[t]{2}{*}{5,000} \\
\hline & 10,000 & 1.680 & 10,000 & 20.00 & 10,000 & \\
\hline \multirow[t]{2}{*}{100} & 0 & 0.164 & -188 & $4^{*}$ & $0^{*}$ & \multirow[t]{2}{*}{5,184} \\
\hline & 10,000 & 1.653 & 9819 & 19.71 & 9,819 & \\
\hline
\end{tabular}

Conclusion: If the Whittaker were calibrated at $80^{\circ} \mathrm{F}$, it is acceptable to operate the RMCS truck at a Whittaker temperature between $60^{\circ} \mathrm{F}$ and $80^{\circ} \mathrm{F}$, however it is likely that the $S A D-0351$ imit of $\leq 1,000 \mathrm{ppm}$ prior to sampling will not be achievable below $70^{\circ} \mathrm{F}$.

Scenario \#6

Whittaker Cell \#4 calibrated at $100^{\circ} \mathrm{F}$.

After scaling the Newport the following values would apply at $100^{\circ} \mathrm{F}$ :

\begin{tabular}{|c|c|c|c|c||}
\hline $\begin{array}{c}\text { Gas Concentration } \\
\text { (ppm } \mathrm{H}_{2} \text { ) }\end{array}$ & $\begin{array}{c}\text { Whittaker } \\
\text { Output (mV) }\end{array}$ & $\begin{array}{r}\text { Newport } \\
\text { Display (ppm) }\end{array}$ & $\begin{array}{c}\text { Newport } \\
\text { Output (mA) }\end{array}$ & $\begin{array}{c}\text { PLC Display } \\
\text { (ppm) }\end{array}$ \\
\hline 0 & 0.164 & 0 & 4.00 & 0 \\
\hline 10,000 & 1.653 & 10,000 & 20.00 & 10,000 \\
\hline
\end{tabular}

The following straight line equations may be used to calculate the Newport and PLC responses for other Whittaker Output values given the scaling of the Newport provided above.

Newport Display $=6716 *($ Whittaker Output $)-1101$

Newport Output $=10.75 *$ (Whittaker Output) +2.24

PLC Display $=6716$ * (Whittaker Output $)-1101$

The actual gas concentration at which the FGI will trip it's 5,000 ppm alarm can be interpolated from the Newport Display values corresponding to 0 and $10,000 \mathrm{ppm} \mathrm{H}_{2}$ at the given temperature. 
THIS PAGE INTENTIONALLY LEFT BLANK 
The responses of the FGI system at varying temperatures are shown below:

\begin{tabular}{|c|c|c|c|c|c|c|}
\hline $\begin{array}{l}\text { Temp, } \\
(\circ \mathrm{f}) \\
\end{array}$ & $\begin{array}{l}\text { Gas conc, } \\
\text { (Ppil H, }\end{array}$ & $\begin{array}{l}\text { Uhittaker } \\
\text { outpout (mV) }\end{array}$ & $\begin{array}{l}\text { Newport } \\
\text { Display (ppon) } \\
\end{array}$ & $\begin{array}{l}\text { Newport } \\
\text { output (mA) }\end{array}$ & $\begin{array}{c}\text { PLC Oisplay } \\
\text { (ppm) }\end{array}$ & $\begin{array}{l}\text { Actual Gas conc, ot, } \\
5,000 \text { ppin alarin trip. }\end{array}$ \\
\hline \multirow[t]{2}{*}{60} & 0 & 0.312 & 994 & 5.59 & 994 & \multirow[t]{2}{*}{3,619} \\
\hline & 10,000 & 1.960 & 12,062 & $20^{*}$ & $10,000^{*}$ & \\
\hline \multirow[t]{2}{*}{70} & 0 & 0.242 & 524 & 4.84 & 524 & \multirow[t]{2}{*}{4,186} \\
\hline & 10,000 & 1.834 & 11,216 & $20^{*}$ & $10,000^{*}$ & \\
\hline \multirow[t]{2}{*}{80} & 0 & 0.192 & 188 & 4.30 & 188 & \multirow[t]{2}{*}{4,815} \\
\hline & 10,000 & 1.680 & 10,181 & $20^{*}$ & $10,000^{*}$ & \\
\hline \multirow[t]{2}{*}{100} & 0 & 0.164 & 0 & 4.00 & 0 & \multirow[t]{2}{*}{5,000} \\
\hline & 10,000 & 1.653 & 10,000 & 20.00 & 10,000 & \\
\hline
\end{tabular}

Conclusion: If the Whittaker were calibrated at $100^{\circ} \mathrm{F}$, it is acceptable to operate the RMCS truck at a Whittaker temperature between $60^{\circ} \mathrm{F}$ and $100^{\circ} \mathrm{F}$, however it is likely that the $S A D-035$ limit of $\leq 1,000 \mathrm{ppm}$ prior to sampling will not be achievable below $80^{\circ} \mathrm{F}$.

Summary

If the Whittaker cell is calibrated between $70^{\circ} \mathrm{F}$ and $100^{\circ} \mathrm{F}$ the RMCS truck may be operated at a Whittaker temperature between $60^{\circ} \mathrm{F}$ and the temperature the calibration was performed at. If the Whittaker cell is calibrated between $70^{\circ} \mathrm{F}$ and $80^{\circ} \mathrm{F}$, the SAD-035 limit of $\leq 1,000 \mathrm{ppm}$ prior to sampling will likely not be achievable at a Whittaker temperature below $10^{\circ} \mathrm{F}$ less than the calibration temperature. If the Whittaker cell is calibrated at $100^{\circ} \mathrm{F}$, the SAD-035 limit of $\leq 1,000$ ppm prior to sampling will likely not be achievable below $80^{\circ} \mathrm{F}$. The best option, if the Whittaker temperature can be maintained above $80^{\circ} \mathrm{F}$ during operation, is to calibrate the Whittaker at $100^{\circ} \mathrm{F}$ since this will maximize the operating temperature range.

Analysis Performed by: 6 wat Wala 21/2/91

Reviewed by:

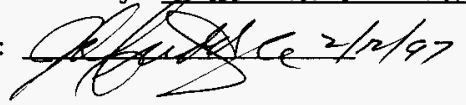


THIS PAGE INTENTIONALLY

LEFT BLANK 